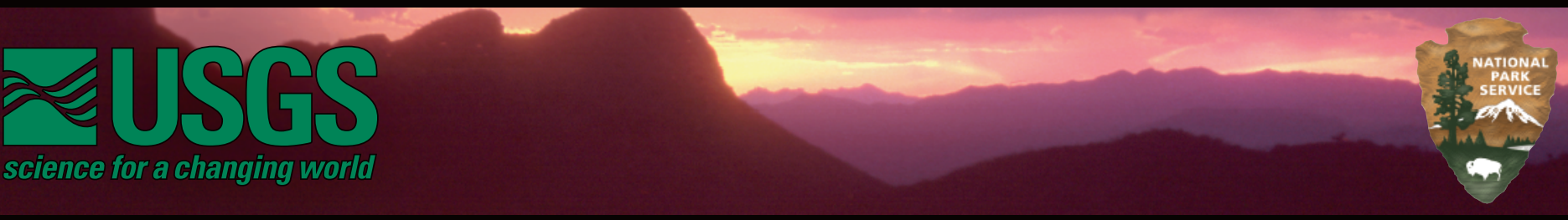

In Cooperation with the University of Arizona, School of Natural Resources

\title{
Vascular Plant and Vertebrate Inventory of Tumacácori National Historical Park
}

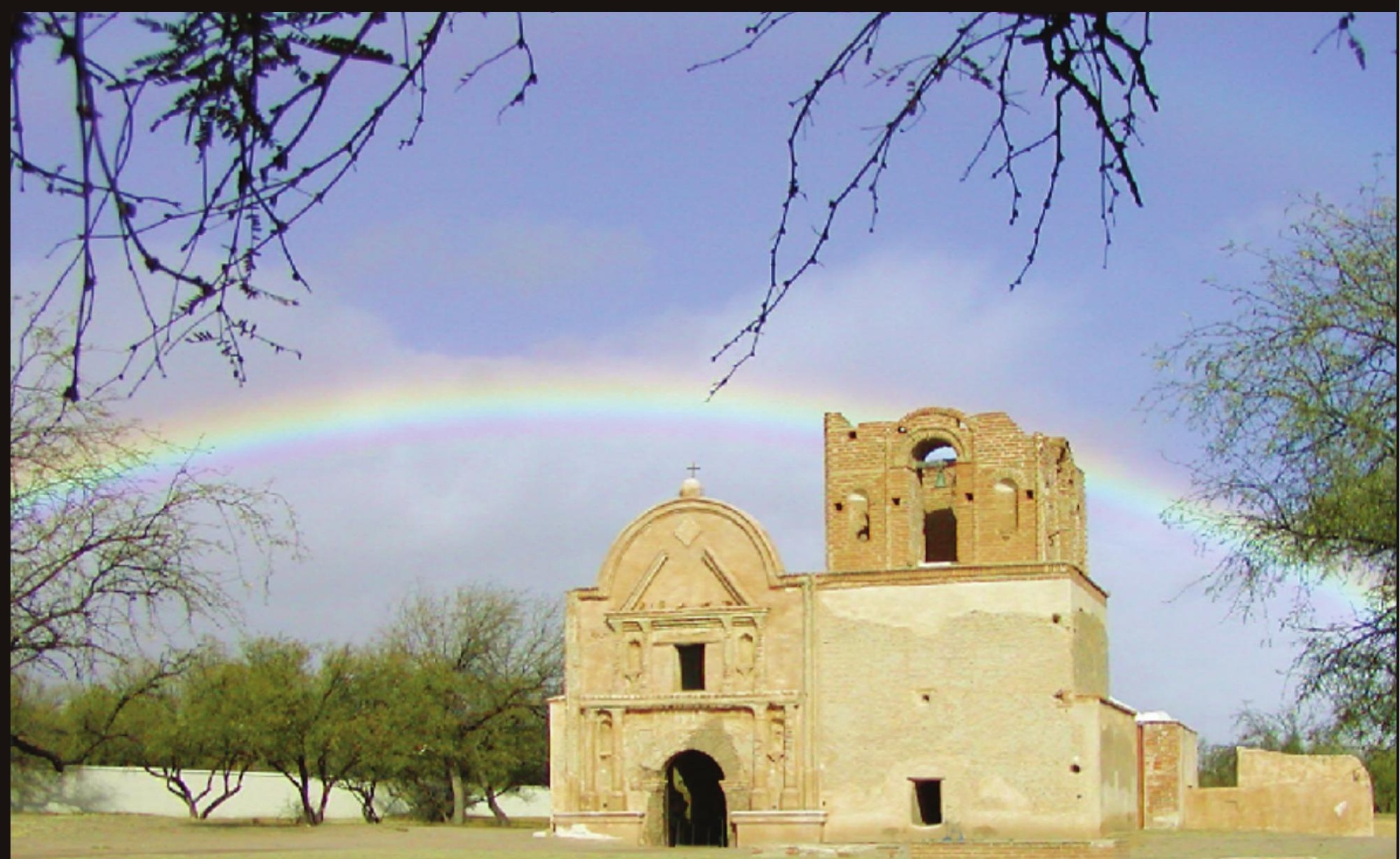

Southwest Biological Science Center

Open-File Report 2005-1142

July 2005

U.S. Department of the Interior

U.S. Geological Survey

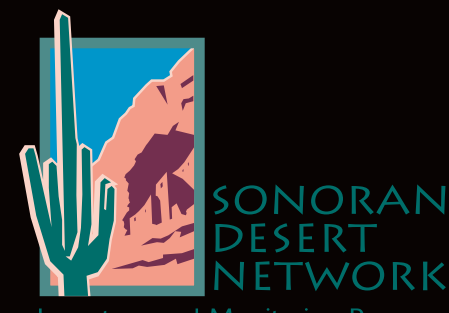

National Park Service 

In cooperation with the University of Arizona, School of Natural Resources

\section{Vascular Plant and Vertebrate Inventory of Tumacácori National Historic Park}

By Brian F. Powell, Eric W. Albrecht, William L. Halvorson, Cecilia A. Schmidt, Pamela Anning, and Kathleen Docherty

Open-File Report 2005-1142

July 2005

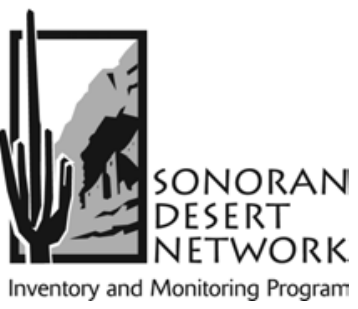

USGS Southwest Biological Science Center

U.S. Department of the Interior

U.S. Geological Survey

National Park Service
Sonoran Desert Research Station University of Arizona School of Natural Resources 125 Biological Sciences East Tucson, Arizona 85721 


\section{U.S. Department of the Interior \\ Gale A. Norton, Secretary}

\section{U.S. Geological Survey \\ P. Patrick Leahy, Acting Director}

U.S. Geological Survey, Reston, Virginia: 2005

Note: This document contains information of a preliminary nature and was prepared primarily for internal use in the U.S. Geological Survey. This information is NOT intended for use in open literature prior to publication by the investigators named unless permission is obtained in writing from the investigators named and from the Station Leader.

Suggested Citation

Powell, B.F., E.W. Albrecht, W.L. Halvorson, C.A. Schmidt, P. Anning, K. Docherty. 2005.

Vascular Plant and Vertebrate Inventory of Tumacácori National Historic Park. USGS Open-File Report 2005-1142. U.S. Geological Survey, Southwest Biological Science Center, Sonoran Desert Research Station, University of Arizona, Tucson, AZ.

This report supersedes Powell et al. (2002, 2003, and 2004).

Cover photo: Ed Wittenberg, Tumacácori National Historic Park 


\section{Authors}

Brian Powell, Eric Albrecht, Cecilia Schmidt, Pamela Anning, and Kathleen Docherty 125 Biological Sciences East Building

School of Natural Resources

The University of Arizona

Tucson, AZ 85721

William L. Halvorson

USGS Sonoran Desert Research Station

125 Biological Sciences East Building

The University of Arizona

Tucson, AZ 85721

\section{U.S. Geological Survey Sonoran Desert Research Station Personnel}

Charles van Riper III, Station Leader

Steve P. Gloss, Ecologist

William L. Halvorson, Research Ecologist

Cecil R. Schwalbe, Ecologist

Michael R. Kunzmann, Ecologist

\section{Program and Expertise Areas of USGS and UA Personnel}

Administration \& Outreach

Cori Dolan

Wendy Parrish

Charles van Riper III

Avian Ecology

Claire Crow

Glenn Johnson

Mike Kunzmann

Chris O'Brien

Brian Powell

Charles van Riper III

Data Management

Mike Kunzmann

Brent Sigafus

Ecology of Amphibians \& Reptiles

Kevin Baker

Cristina Jones

Dave Prival

Phil Rosen

Cecil Schwalbe

Brent Sigafus

Eric Stitt

Dennis Suhre
Fire Management

Cori Dolan

James Feldmann

Bill Halvorson

Invasive Species Research

Patricia Guertin

Jim Malusa

Phil Rosen

Cecil Schwalbe

Brent Sigafus

Dennis Suhre

Inventory \& Monitoring

Patricia Guertin

Bill Halvorson

Brian Powell

Cecilia Schmidt

Vegetation Mapping \& Ecology

Patricia Guertin

Bill Halvorson

Jim Malusa

USGS Southwest Biological Science Center http://sbsc.wr.usgs.gov 


\section{Table of Contents}

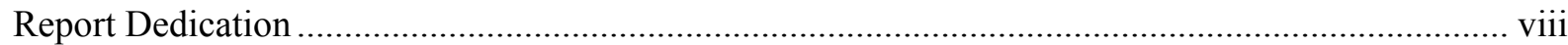

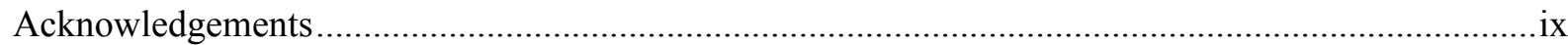

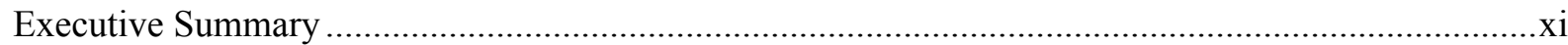

Chapter 1: Introduction to the Biological Inventories at Tumacácori NHP ........................................ 1

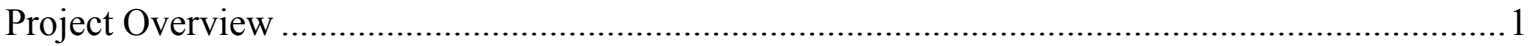

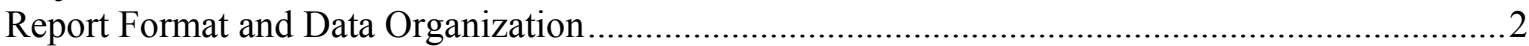

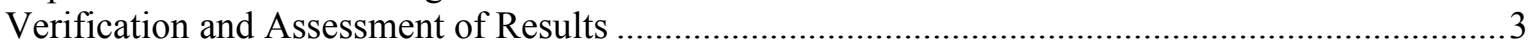

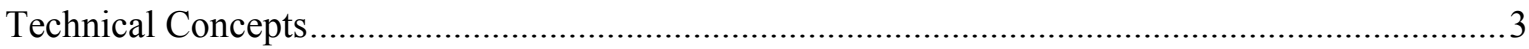

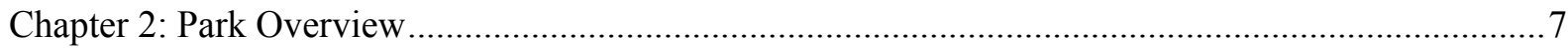

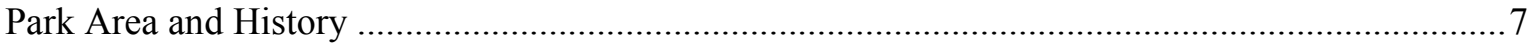

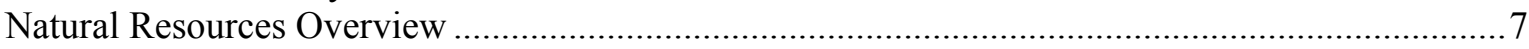

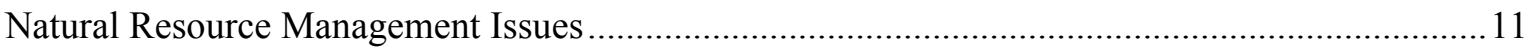

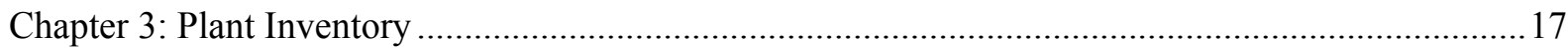

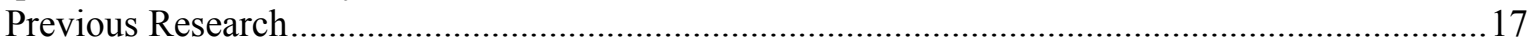

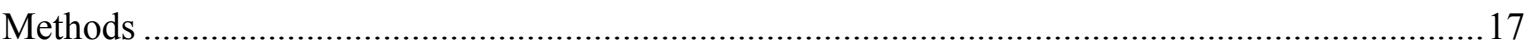

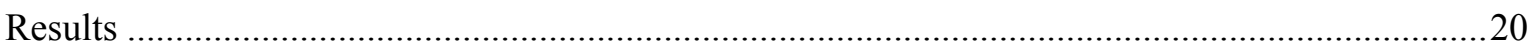

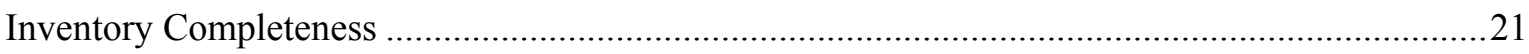

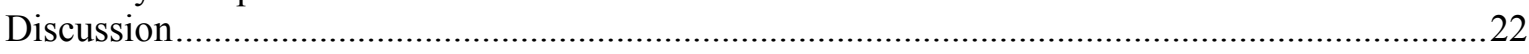

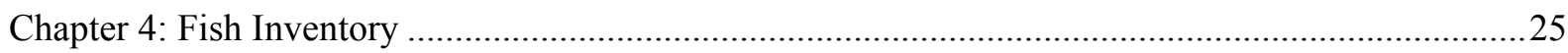

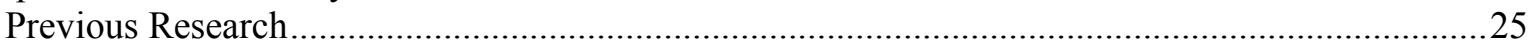

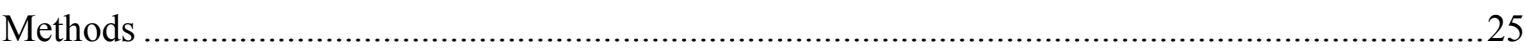

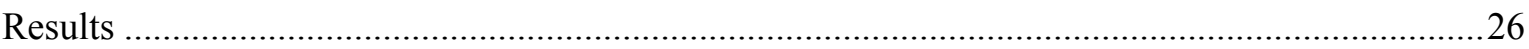

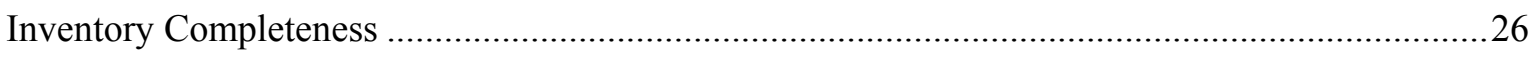

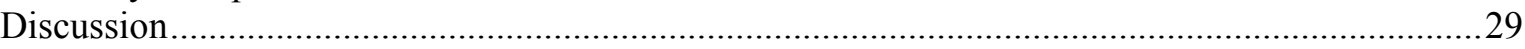

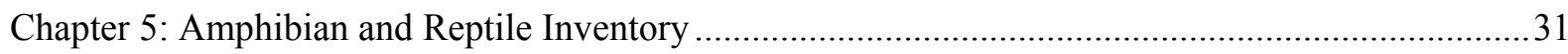

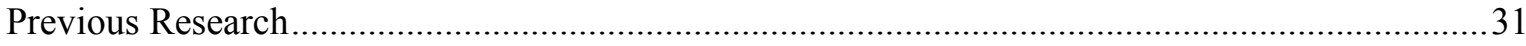

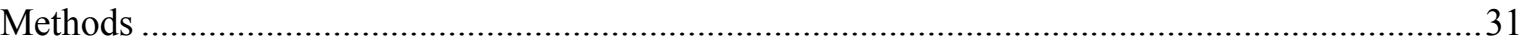

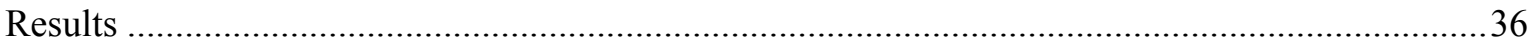

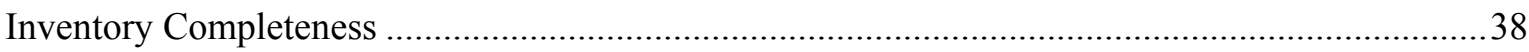

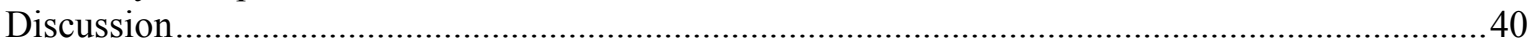

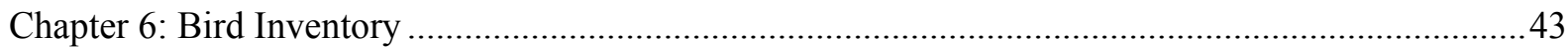

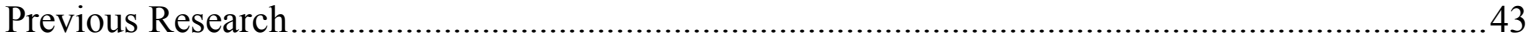

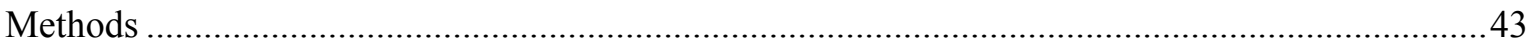

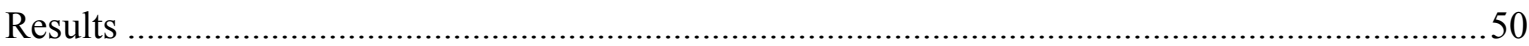

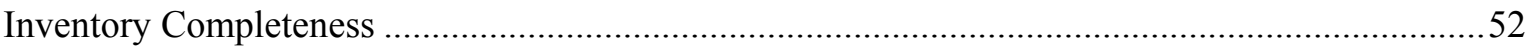

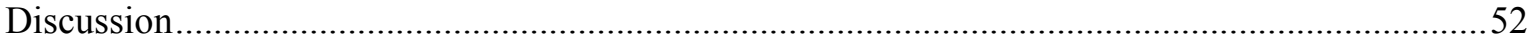

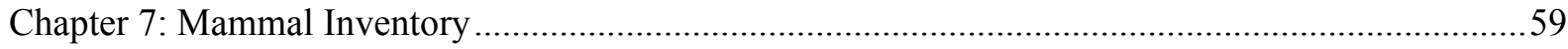

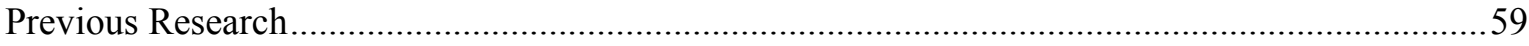

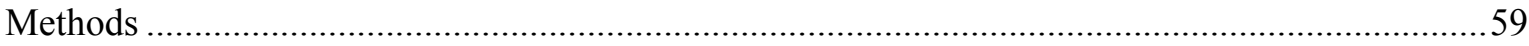

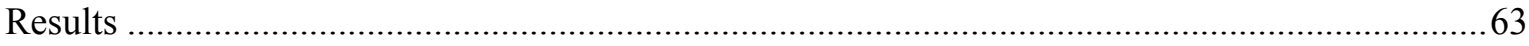

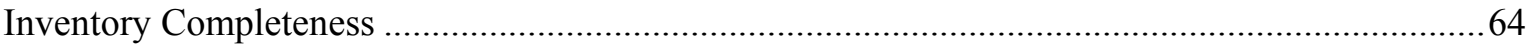

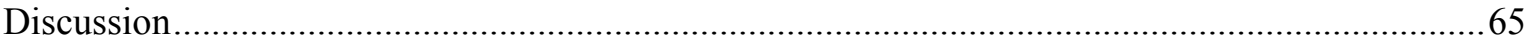

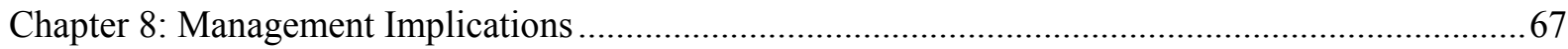


Chapter 9: Additional Inventories.

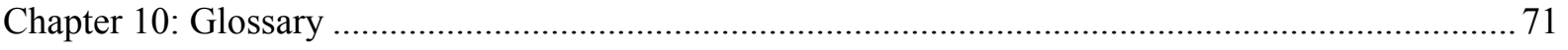

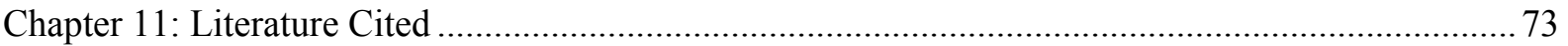

\section{List of Tables}

Table E.S.1. Summary results of vascular plant and vertebrate inventories at Tumacácori

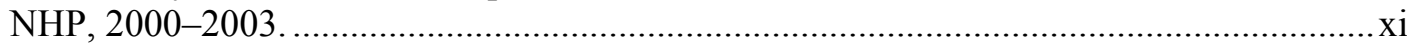

Table 2.1. Average monthly climate data for Tumacácori NHP, 1948-2003 (data from WRCC

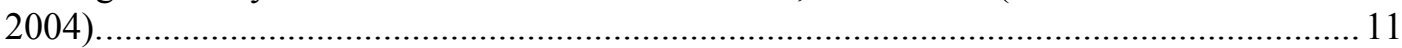

Table 4.1. Number of fish caught during four sampling periods at Tumacácori NHP, 2001-

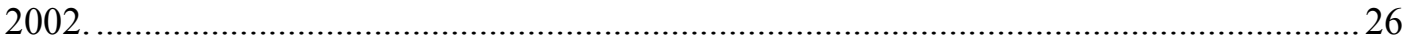

Table 5.1. Amphibian and reptile survey effort by method, Tumacácori NHP, 2001-2002 ............... 31

Table 5.2. Relative abundance of reptiles ${ }^{\mathrm{a}}$ recorded during intensive surveys, by community type and park unit, Tumacácori NHP, 2001-2002. .

Table 5.3. Number of amphibians and reptiles recorded per 10 hours of extensive surveys, and number of incidental observations for additional species, by park unit, Tumacácori NHP, 2001-2002.

Table 5.4. Number of animals captured per 100 hours of pitfall trap operation, Tumacácori unit, Tumacácori NHP, 2001-2002...

Table 6.1. Bird survey effort by method and community type, Tumacácori NHP, 2001-2003.......... 46

Table 6.2. Relative abundance of birds recorded during VCP surveys, all units, Tumacácori NHP, 2001-2002.

Table 6.3. Relative abundance of birds recorded during line-transect surveys, all units, Tumacácori NHP, 2002-2003.

Table 6.4. Observations of breeding behavior by birds, Tumacácori NHP, 2001-2002.

Breeding codes follow standards set by NAOAC (1990).

Table 7.1. Total number of small mammals trapped (n) and relative abundance (RA), excluding recaptures, by park unit, Tumacácori NHP, 2000-2001

Table 7.2. Results from infrared-triggered cameras, Tumacácori unit, Tumacácori NHP, 2000-2001.

\section{List of Figures}

Figure 2.1. Locations of the three units of Tumacácori NHP in southern Arizona. ............................ 8

Figure 2.2. Aerial photograph of the study area and park boundary, Tumacácori unit, Tumacácori NHP.

Figure 2.3. Aerial photographs of the Calabazas and Guevavi units, Tumacácori NHP.

Figure 2.4. Comparison of monthly weather data during the time of the inventory (2000 2002) compared to the mean (1948-2004; thick solid line in both figures), Tumacácori NHP (data from WRCC 2004).

Figure 2.5. Trash accumulation along the Santa Cruz River, Tumacácori NHP, August 2002

Figure 3.1. Locations of modular plots for plants, Tumacácori unit, Tumacácori NHP, 2002. See Appendix J for plot coordinates.

Figure 3.2. Typical modular plot layout of four $10 \times 10$ m modules, eight $1 \times 1$ m quadrats, and four 10-m point-intercept transects, Tumacácori unit, Tumacácori NHP, 2002. 
Figure 3.3. Species accumulation curve for cumulative number of new plant species collected as a function of the number of sample days, general botanizing and modular plot surveys, all units, Tumacácori NHP, 2000-2003.

Figure 3.4. Cumulative (A) and number of new plant species (B) recorded as a function of the number of modular plots surveyed, Tumacácori unit, Tumacácori NHP, 2002.

Figure 4.1. Total catch and species richness of fish, by sampling period, Tumacácori NHP, 2001-2002.

Figure 4.2. Percent total catch, by sampling period, for the three most common species of fishes at both sampling sites, Tumacácori NHP, 2001-2002 ........................................28

Figure 4.3. Crayfish, Tumacácori NHP, November 2002 ….......................................................... 30

Figure 5.1. Locations of intensive survey plots and pitfall trap array for amphibians and reptiles, Tumacácori unit, Tumacácori NHP, 2001-2002.

Figure 5.2. Locations of intensive survey plots for amphibians and reptiles, Calabazas and Guevavi units, Tumacácori NHP, 2001-2002

Figure 5.3. Species accumulation curves for intensive and extensive amphibian and reptile surveys, Tumacácori NHP, 2001-2002.

Figure 5.4. American bullfrog, Tumacácori NHP.

Figure 6.1. Locations of VCP survey stations and line-transect breaks (winter) for birds, Tumacácori unit, Tumacácori NHP, 2001-2003. 44

Figure 6.2. Locations of VCP survey stations and line-transect breaks (winter) for birds, Calabazas and Guevavi units, Tumacácori NHP, 2002-2003. 45

Figure 6.3. Species accumulation curves for number of bird species by sample event (i.e., survey days) for VCP and line-transect surveys, all units, Tumacácori NHP, 2001-2003.

Figure 7.1. Locations of small mammal trapping plots and infrared-triggered cameras, Tumacácori unit, Tumacácori NHP, 2000-2001.

Figure 7.2. Locations of small mammal trapping plots, Calabazas and Guevavi units, Tumacácori NHP, 2000-2001.

Figure 7.3. Diagram of infrared-triggered camera set-up.

Figure 7.4. Species accumulation curve for small mammal trapping, all park units, Tumacácori NHP, 2000-2001.

\section{List of Appendices}

Appendix A. List of plant species that were observed (O) or documented (D) at Tumacácori NHP by University of Arizona Inventory personnel, 2000-2003.

Appendix B. Fish species recorded in the Santa Cruz River and Tumacácori Channel by University of Arizona Inventory personnel, Tumacácori NHP, 2001-2002.

Appendix C. Amphibian and reptile species that were observed $(\mathrm{O})$, documented with photo voucher $(\mathrm{P})$, or documented with specimen voucher $(\mathrm{S})$ by University of Arizona Inventory personnel, Tumacácori NHP, 2001-2002..

Appendix D. Bird species recorded at Tumacácori NHP by University of Arizona Inventory personnel, 2001-2003, and by personnel working for the Monitoring Avian Productivity and Survivorship Program (MAPS), 1997-2003.

Appendix E. Mammal species observed or documented by University of Arizona Inventory personnel or were found in museum collections (Appendix O), Tumacácori NHP, 2001-2002. 
Appendix F. Plant species recorded at the Tumacácori unit by previous researchers but not recorded by University of Arizona Inventory personnel, Tumacácori NHP.

Appendix G. Amphibian and reptile species that were not recorded by University of Arizona Inventory personnel but that may occur at Tumacácori NHP based on documentation in the area by other researchers, or based on published range maps

Appendix H. Bird species that were not recorded by University of Arizona Inventory personnel but that may occur at Tumacácori NHP.

Appendix I. Mammal species that were not recorded by University of Arizona Inventory personnel or were found in museum collections (Appendix O), but that may occur at Tumacácori NHP.

Appendix J. UTM coordinates (NAD 83) of vegetation (modular) survey plots at the Tumacácori Unit, Tumacácori NHP, 2002.

Appendix K. UTM coordinates (NAD 83) for intensive plots for amphibian and reptile surveys, Tumacácori NHP, 2001-2002.

Appendix L. UTM coordinates (NAD 83) for bird survey stations and transect sections, Tumacácori NHP, 2001-2003.

Appendix M. UTM coordinates (NAD 83) of small mammal trapping plots, Tumacácori NHP, 2000-2001

Appendix N. Museums that were queried in 1998 for vertebrate voucher specimens with "Arizona" and "Tumacácori National Historical Park" in the collection location.

Appendix O. Voucher specimens from Tumacácori NHP that were not collected by University of Arizona Inventory personnel.

Appendix P. Vertebrate voucher specimens collected at Tumacácori NHP by University of Arizona Inventory personnel, 2000-2002.

Appendix Q. Summary of plant data from modular plots, Tumacácori NHP, 2002.

Appendix R. Plant species recorded in 10 x 10 m modular plots (P), point-intercept transects within modular plots (TR) or in both modular plots and point-intercept transects (B), Tumacácori NHP, 2002.

Appendix S. Results of fish surveys at Tumacácori NHP, 2001-2002. These data are summarized in Table 5.1....

Appendix T. Total number of birds detected during incidental observations and VCP surveys for the time period of the most intensive surveys, Tumacácori NHP, 2001-2002...... 123

Appendix U. Summary of vegetation characteristics measured at VCP survey stations, Tumacácori NHP, 2002. 


\section{Report Dedication}

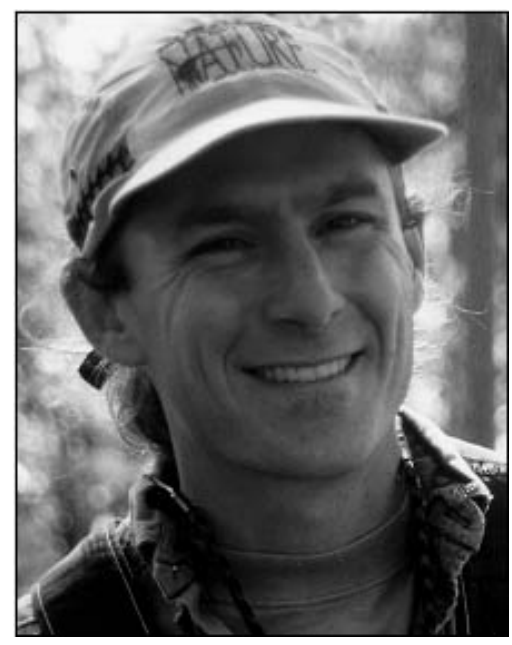

\section{Eric Wells Albrecht 1970-2004}

This report is dedicated to Eric's life and work; he was an extraordinary ecologist, community member, father, partner, and friend. Eric was co-coordinator of the University of Arizona (UA) biological inventory and monitoring program from 2002 until his sudden and unexpected death on September 20, 2004. Eric was near completion of his MS degree in Wildlife Conservation from the UA, which was awarded posthumously in November 2004. In his last year, Eric spearheaded projects to investigate the efficiency of current monitoring programs; he was passionate about using the best available information to guide vertebrate monitoring efforts in the region. He is survived by his partner, Kathy Moore, and their two young children, Elizabeth and Zachary. We hope that the lives of his children will be enriched by Eric's hard work on behalf of the national parks in the Sonoran Desert Network. 


\section{Acknowledgements}

Thanks to Park Superintendent Ann Rasor, Roy Simpson, and the staff at Tumacácori National Historical Park (NHP) for their strong support of the Inventory Program. We are very pleased that data from our studies played a role in the legislated and actual expansion of the park boundary. Ms. Rasor deserves much of the credit for applying scientific data to management action; we recognize and applaud her vision.

This project resulted from the collaboration of many people at the United State Geological Survey (USGS), the University of Arizona (UA) and the National Park Service (NPS) and was facilitated by the Southern Arizona Office of the National Park Service, and Desert Southwest and Colorado Plateau Cooperative Ecosystem Studies Units (CESUs). Andy Hubbard at the Sonoran Desert Network (SDN) Inventory and Monitoring (I\&M) program has been a strong and convincing advocate for continuing and expanding the role of the USGS/UA Inventory in the I\&M program. Kathy Davis at Tuzigoot and Montezuma Castle national monuments was instrumental for her initiative early in this project. Larry Norris at the Desert Southwest CESU provided strong support for our program and spent considerable time and effort providing clear and timely administrative assistance. Matt Goode, Don Swann, and Dale Turner provided much of the early planning for this project; we are indebted to their vision and work. Eric Albrecht, to whom this report is dedicated, was an outstanding spokesperson and leader of the program; he was an invaluable member of the team and his contributions are sorely missed. We are grateful to George Binney, Roy Ross, and Hank Cosper for allowing us access to their lands.

We thank a core group of dedicated field biologists who persevered, day in and day out, to collect a wealth of data at Tumacácori NHP: Patty Guertin, Sky Jacobs, James MacAdam, Jeff McGovern, Katie Nasser, and Meg Quinn (plants); Miguel Lerma, Michael Olker, Andy Schultz, and Thomas Walker (fish); Dan Bell, Kevin Bonine, James Borgmeyer, Dave Prival, and Mike Wall (amphibians and reptiles); Gavin Beiber, Aaron Flesch, Chris Kirkpatrick, and Gabe Martinez (birds); Melanie Bucci, Ryan Gann, Ed Kuklinski, Neil Perry, Jason Schmidt, and Ronnie Sidner (mammals). We are appreciative of the following people, many of whom never ventured into the field, but whose office tasks made the field effort possible: Debbie Angell, Jennifer Brodsky, Brian Cornelius, Carianne Funicelli, Taylor Edwards, Colleen McClain, Heather McClaren, Lindsay Norpel, Jill Rubio, Brent

Sigafus, Taffy Sterpka, Patina Thompson, Jenny Treiber, and Alesha Williams. Special thanks to Lisa Carder for her years of hard work on all aspects of the project.

Additional administrative support was provided by Valery Catt at the USGS Sonoran Desert Research Station and Terri Rice, Andy Honaman, Jenny Ferry, and especially Cecily Westphal of the School of Natural Resources at the UA. Technical support was graciously given by the following experts: Dan Austin, Michael Chamberland, Phil Jenkins, and Charlette and John Reeder of the UA herbarium; George Bradley of the UA herpetology collection; Peter Reinthal of the UA fish collection; Tom Huels of the UA ornithology collection; and Yar Petryszyn and Melanie Bucci of the UA mammal collection. Thanks to Sharon Megdal, Peter Wierenga, and all the staff at the UA Water Resources Research Center, especially Terry Sprouse and colleagues (Sprouse et al. 2002) for use of background information on Tumacácori NHP contained in this report.

We received helpful comments on earlier drafts of this report from Debbie Angell, Kevin Bonine, James Feldmann, Denny Fenn, Andy Hubbard, Brooke Gebow, Larry Laing, Theresa Mau-Crimmins, Larry Norris, Ann Rasor, Phil Rosen, and Don Swann. All mistakes and omissions are the responsibility of the authors. 


\section{Executive Summary}

This report summarizes the results of the first comprehensive biological inventory of Tumacácori National Historical Park (NHP) in southern Arizona. These surveys were part of a larger effort to inventory vascular plants and vertebrates in eight National Park Service units in Arizona and New Mexico.

From 2000 to 2003 we surveyed for vascular plants and vertebrates (fish, amphibians, reptiles, birds, and mammals) at Tumacácori NHP to document presence of species within the administrative boundaries of the park's three units. Because we used repeatable study designs and standardized field techniques, these inventories can serve as the first step in a long-term monitoring program.

We recorded 591 species at Tumacácori NHP, significantly increasing the number of known species for the park (Table 1). Species of note in each taxonomic group include:

- Plants: second record in Arizona of muster John Henry, a non-native species that is ranked a "Class A noxious weed" in California;

- Amphibian: Great Plains narrowmouthed toad;

- Reptiles: eastern fence lizard and Sonoran mud turtle;

- Birds: yellow-billed cuckoo, green kingfisher, and one observation of the endangered southwestern willow flycatcher;

- Fishes: four native species including an important population of the endangered Gila topminnow in the Tumacácori Channel;

- Mammals: black bear and all four species of skunk known to occur in Arizona.

We recorded 79 non-native species (Table E.S. 1), many of which are of management concern, including: Bermudagrass, tamarisk, western mosquitofish, largemouth bass, bluegill, sunfish, American bullfrog, feral cats and dogs, and cattle. We also noted an abundance of crayfish (a non-native invertebrate). We review some of the important non-native species and make recommendations to remove them or to minimize their impacts on the native biota of the park.

Based on the observed species richness, Tumacácori NHP possesses high biological diversity of plants, fish, and birds for a park of its size. This richness is due in part to the ecotone between ecological provinces (Madrean and Sonoran), the geographic distribution of the three units (23 km separates the most distant units), and their close proximity to the Santa Cruz River. The mesic life zone along the river, including rare cottonwood/willow forests and adjacent mesquite bosque at the Tumacácori unit, is representative of areas that have been destroyed or degraded in many other locations in the region. Additional elements such as the semi-desert grassland vegetation community are also related to high species richness for some taxonomic groups.

Table E.S.1. Summary results of vascular plant and vertebrate inventories at Tumacácori NHP, 2000-2003.

\begin{tabular}{lrrr}
\hline Taxon group & $\begin{array}{c}\text { Number of } \\
\text { species } \\
\text { recorded }\end{array}$ & $\begin{array}{c}\text { Number of } \\
\text { non-native } \\
\text { species }\end{array}$ & $\begin{array}{c}\text { Number of new } \\
\text { species added to } \\
\text { park lista }^{2}\end{array}$ \\
\hline Plants & 378 & 67 & 168 \\
Fish & 8 & 4 & 3 \\
Amphibians & 24 & 1 & 22 \\
and Reptiles & 146 & 3 & 40 \\
Birds & 35 & 4 & 33 \\
Mammals & $\mathbf{5 9 1}$ & $\mathbf{7 9}$ & $\mathbf{2 6 6}$ \\
\hline Totals & \multicolumn{4}{l}{} \\
a Species that had not been observed or documented by \\
previous studies.
\end{tabular}

This report includes lists of species recorded by us (or likely to be recorded with additional effort) and maps of study sites. We also suggest management implications and ways to maintain or enhance the unique biological resources of Tumacácori NHP: limit development adjacent to the park, exclude 
cattle and off-road vehicles, develop an

eradication plan for non-native species, and hire a natural resource specialist. These recommendations are intended to assist park staff with addressing many of the goals set out in their most recent natural resources management plan.

This study is the first step in a long-term process of compiling information on the biological resources of Tumacácori NHP and its surrounding areas, and our findings should not be viewed as the final authority on the plants and animals of the park. Therefore, we also recommend additional inventory and monitoring studies and identify components of our effort that could be improved upon, either through the application of new techniques (e.g., use of genetic markers) or by extending the temporal and/or spatial scope of our research. 


\title{
Chapter 1: Introduction to the Biological Inventories at Tumacácori NHP
}

\author{
The unnamed is the heaven and earth's origin; \\ Naming is mother of ten thousand things. \\ Lao Tzu
}

\section{Project Overview}

Inventory: A point-in-time effort to document the resources present in an area.

In the early $1990 \mathrm{~s}$, responding to criticism that it lacked basic knowledge of natural resources within parks, the National Park Service (NPS) initiated the Inventory and Monitoring Program (NPS 1992). The purpose of the program is to increase scientific research in NPS units and to detect long-term changes in biological resources (NPS 1992). At the time of the program's inception, basic biological information, including lists of plants and animals, were absent or incomplete for many parks. In fact, as of 1994 , more than $80 \%$ of national parks did not have complete inventories of major taxonomic groups (Stohlgren et al. 1995).

Species inventories have both direct and indirect value for management of natural areas. Species lists facilitate resource interpretation and visitor appreciation of natural resources. Knowledge of which species are present, particularly sensitive species, and where they occur is critical for making management decisions (e.g., locating new facilities). Inventories are also a cornerstone of long-term monitoring. Thorough biological inventories provide a basis for choosing parameters to monitor and can provide initial data (i.e., a baseline) for monitoring ecological populations and communities. Inventories can also test sampling strategies, field methods, and data collection protocols, and provide estimates of variation that are essential in prospective power analyses.

Goals

The purpose of this study was to complete basic inventories for vascular plants and vertebrates at Tumacácori NHP. This effort was part of a larger biological inventory of eight NPS units in southern Arizona and southwestern New Mexico (Davis and Halvorson 2000). The goals of our biological inventory of Tumacácori NHP were to:

1. Conduct field surveys with the goal of documenting at least $90 \%$ of all species of vascular plants and vertebrates estimated to occur at the park.

2. Use repeatable sampling designs and survey methods (when appropriate) that allow estimation of parameters of interest (e.g., species richness and relative abundance by taxonomic group) with associated estimates of precision.

3. Compile historical occurrence data, for all species of vascular plants and vertebrates, from three sources: museum records (voucher specimens), previous studies, and park records.

4. Create resources that are useful to park managers, including detailed species lists, maps of study sites, and high-quality digital images for use in resource interpretation and education.

The bulk of our effort addressed goal numbers 1 and 2. To maximize efficiency of realizing these goals (i.e., the number of species recorded by effort) we used field techniques designed to detect multiple species. We did not undertake single-species survey for threatened or endangered species.

\section{Administrative History}

The inventory project at Tumacácori NHP is the first of eight park inventories to be completed by our group. Funding for this project was obligated by the NPS in federal fiscal year 2000 (through work order No. 5 under cooperative agreement number 
1443CA860197006), and administered through the Southern Arizona Office of NPS. Additional effort for biological inventories at Tumacácori NHP was funded through the Desert Southwest CESU UAZ-57 under cooperative agreement 1248-00-002 in federal fiscal year 2002. The methodology used for the vegetation surveys in the riparian area was changed to be compatible with that used by other researchers completing surveys in other Sonoran Desert Network parks. This report integrates findings from these two projects and thus serves as the product for each.

\section{Report Format and Data Organization}

This report includes summaries and analyses of data related to vascular plants and vertebrates (fish, amphibians, reptiles, birds, mammals) collected from 2000 to 2003 at Tumacácori NHP. This report is intended for use by park managers, and as such we strive to make it relevant, easy to read, and well organized. Our intention is for this document to be used in internal planning processes and outreach and education. We report only common names (listed in phylogenetic sequence) unless we reference a species that is not listed later in an appendix, in which case we use both common and scientific names. For each taxon group we include an appendix of all species that we recorded in the park (Appendices A-E) or which we suspect may be recorded with additional survey effort (Appendices F-I). Species lists are in phylogenetic sequence and include taxonomic order, family, genus, species, subspecies (if applicable) and common name. Scientific and common names used throughout this document are current according to accepted authorities for each taxon: Integrated Taxonomic Information System (ITIS 2004) and the PLANTS database (USDA 2004) for plants; Robins (1991) for fish; Stebbins (2003) for amphibians and reptiles; American Ornithologist Union (AOU 1998, 2003) for birds; and Baker et al. (2003) for mammals. In this document we subscribe to the International System of Units (SI).

\section{Spatial Data}

Most spatial data associated with this project are geographically referenced to facilitate mapping study plots and locations of plants or animals. Coordinate storage is the Universal Transverse Mercator (UTM) projection with North American datum 1983 (NAD 83), Zone 12. We recorded most UTM coordinates using hand-held Garmin E-Map ${ }^{\circledR}$ Global Positioning System (GPS) units (Garmin International Incorporated, Olathe, KS) (horizontal accuracy about 10-30 m) because of their ease of use. We obtained some plot or station locations by using more accurate Trimble Pathfinder ${ }^{\mathbb{B}}$ GPS units (Trimble Navigation Limited, Sunnyvale, CA; horizontal accuracy about $1 \mathrm{~m}$ ). Unless otherwise noted, we used E-Map units. Not all reported UTM coordinates are accurate representations of the plant or animal location. For example, UTM coordinates for plot-based detections are for the plot corners (Appendices $\mathrm{J}-\mathrm{M}$ ). Bird sightings are an exception; the UTM coordinates were typically within $150 \mathrm{~m}$ of the station or transect line, but in rare cases were as far as $300 \mathrm{~m}$ away.

We map the location of all plots or stations using Digital Orthophoto Quarter Quads (DOQQ; produced by the U.S. Geological Survey) as background images when projecting features of interest (Figs 1.2, 1.3, $3.1,5.1,5.2,6.1,6.2,7.1,7.2$ ). Images of the Tumacácori unit are from the Tubac DOQQ (1996) and images of the Calabazas and Guevavi units are from the Rio Rico DOQQ (1994).

\section{Species Conservation Designations}

In this report we indicate species conservation designations by agencies, including U.S. Fish and Wildlife Service (responsible for administering the Endangered Species Act), Bureau of Land Management, U.S. Forest Service, Arizona Game and Fish Department, and Arizona Partners in Flight (a partnership of dozens of federal, state and local governments, non-governmental organizations). 


\section{Databases and Data Archiving}

We entered field data into taxon-specific databases (Microsoft Access version 97) and checked all data for transcription errors. From these databases we reproduced copies of the original field datasheets using the "Report" function in Access. The output looks similar to the original datasheets but all data are easier to read. The databases, printouts, and other data such as digital photographs and GIS layers will be distributed to monument staff, associated cooperators, and to the following data repositories:

- Southern Arizona Office, National Park Service; Phoenix, Arizona

- University of Arizona, Special Collections, Main Library; Tucson, Arizona

Original copies of all datasheets will be given to the NPS SDN I\&M program office in Tucson and may be archived at an another location. This redundancy in data archiving is to ensure that these valuable data are never lost. Along with the archived data we will include copies of the original datasheets and a guide to filling out the datasheets. This information, in conjunction with the text of this report, should enable future researchers to repeat our work.

\section{Verification and Assessment of Results}

\section{Photo Vouchers}

Whenever possible we documented vertebrate species with analog color photographs. Many of these photos show detail on coloration or other characteristics of visual appearance, and they may serve as educational tools for the monument staff and visitors. Photographs will be archived with other data as described above.

\section{Voucher Specimens}

In many cases we collected voucher specimens to verify identifications and document species presence. Before taking vertebrate voucher specimens, we checked for existing vouchers in a database of 36 natural history museums (Appendix N) for records from Tumacácori NHP (see Appendix O for results). For plants, we searched the University of Arizona herbarium (see Appendices A and $\mathrm{F}$ for results). We collected herbarium specimens whenever flowers or fruit were present. All specimens were accessioned into the University of Arizona herbarium. Plant voucher specimens from this project are listed in Appendix A.

For vertebrate specimens we preferred to use individuals that were killed incidentally (e.g., by cars), but occasionally we euthanized animals, particularly when identification was difficult or uncertain. For example, many small mammal species exhibit subtle variations in pelage color patterns within species and overlapping external measurements among species). The University of Arizona's Institution for Animal Care and Use approved all field protocols for euthanizing animals (Protocol Control Number 03-177). We prepared all specimens according to standardized techniques and accessioned them into the appropriate University of Arizona vertebrate collection (vertebrate vouchers are listed in Appendix P).

\section{Assessing Inventory Completeness}

Assessing inventory completeness can most easily be accomplished by (1) examining the rate at which new species were recorded in successive surveys (i.e., species accumulation curves; Hayek and Buzas 1997: 314) and (2) by comparing the list of species we recorded with a list of species likely to be present based on previous research and/or expert opinion. We used different strategies tailored to each taxonomic group; for instance, it is not realistic to construct a list of potential plant species and so we used species accumulation curves. For all species accumulation curves, we randomized the order of the sampling periods to break up clusters of new detections that resulted from temporal conditions (e.g., monsoon initiation) independent of cumulative effort.

\section{Technical Concepts}

This section introduces some technical concepts and considerations related to our research at Tumacácori NHP. We also include 
a glossary (Chapter 10) in which we define common terms used in this document.

\section{Habitat}

Habitat is a species-specific term referring to an area with resources and environmental conditions promoting occupancy, survival, and reproduction of that species (Morrison et al. 1998). Thus, referring to an area as "cottonwood habitat" indicates that the area supports this tree species, not that it supports a host of other species that may be (or in some times/locations may not be) associated with cottonwoods (e.g., yellow warblers). This also precludes general use of the term "riparian habitat", a common usage that may result from confusion with the similar concept of "habitat type," a term introduced by Daubenmire (1976) and defined as "land units having approximately the same capacity to produce vegetation."

In this report we refer to "community types" as a means of comparing vertebrate communities in areas with different vegetation and other environmental associations. Community types are identified differently in relation to amphibians and reptiles (Chapter 5) and birds (Chapter 6). A preferred approach to classifying community types would involve use of an objective source such as a vegetation map, which had not been developed for the park at the time of writing.

\section{Sampling Design}

Sampling design is the process of selecting sample units from a population or area of interest. Unbiased random samples allow inference to the larger population from which those samples were drawn. The precision of estimates, based on these samples, increases with the number of samples taken; theoretically, random samples can be taken until all possible samples have been selected and precision is exact - a census has been taken that approaches the true value. Nonrandom samples are less likely to be representative of the entire population, because the sample may be intentionally biased toward a characteristic of interest or convenience.
We briefly address sampling design in each chapter. In general our survey plots were not randomly located because we were more interested in detecting the maximum number of species than in maintaining inference to a larger area. Thus, abundance estimates (relative abundance) detailed in this report may be biased because we surveyed in areas likely to have high species richness; however the nature of that bias is difficult to characterize or quantify. If population estimates were a higher priority, avoiding this potential bias would have had greater importance. For a thorough review of issues related to sampling design, see Thompson (1992).

\section{Estimates of Abundance}

Estimating population size is a common goal of biologists, generally motivated by the desire to reduce (pest species), increase (endangered species), maintain (game species) or monitor (indicator species) populations. Use of abundance estimates as an indication of habitat quality has been soundly criticized (Van Horne 1983). Our surveys at Tumacácori NHP were generally focused on detecting species rather than estimating population size. In many cases, however, we present estimates of "relative abundance" by species, to give a general sense of species abundance among community types, and provide information on areas in which species might be more or less common. Relative abundance is an index to population size that we calculate as the number of individuals of a species recorded, scaled by the amount of effort used to record that number. Some researchers (particularly plant, marine, and invertebrate ecologists) prefer to scale such frequency counts by the number of observations of other species, which provides a measure of community dominance; abundance relative to other species present.

Indices of abundance correlate with population size but do not attempt to account for variation in detectability among different species or groups of species under different circumstances. Metrics of abundance that consider variation in detection probability include density (number of individuals per unit 
area; e.g., two northern cardinals per hectare of mesquite bosque), and absolute abundance (population size; e.g., 48 northern cardinals at Tumacácori NHP). These latter techniques are beyond the scope of our research. For a review of methods used to estimate abundance, see Lancia et al. (1996). 


\section{Chapter 2: Park Overview}

\section{Park Area and History}

Park History

Tumacácori NHP preserves the remnants of three Spanish colonial missions located along the upper Santa Cruz River in southern Arizona. Originally established in 1908 as a monument under the Antiquities Act, the park protected the San Jose de Tumacácori (Tumacácori unit), a Spanish mission founded in 1691. In 1990, the area was designated a National Historical Park with the inclusion of Los Santos Angeles de Guevavi mission (Guevavi unit; founded in 1691) and San Cayetano de Calabazas mission (Calabazas unit; founded in 1756).

\section{Park Boundaries}

Tumacácori NHP contains three units: Calabazas, Guevavi and Tumacácori. Tumacácori is the main administrative unit. The Calabazas and Guevavi units are $15 \mathrm{~km}$ and $23 \mathrm{~km} \mathrm{SSE}$ of the Tumacácori unit, respectively (Figs. 2.1-2.3). The park contains two perennial stretches of the Santa Cruz River (in the Tumacácori and Guevavi units; Figs. $2.2,2.3)$. In the summer of 2002 , the U.S. Congress legislated expansion and (later) allocated money for the acquisition of an additional 125 ha located adjacent to the Tumacácori unit along the Santa Cruz River (Fig. 2.2). Unless otherwise noted, the "Tumacácori unit" collectively refers to the legislated boundary (Fig. 2.2) and a few areas just outside of the boundary.

\section{Natural Resources Overview}

The three units of Tumacácori NHP are associated with distinct pockets of reliable water, resulting from basin-fill sediments over relatively shallow aquifers that fill quickly after precipitation (Sprouse et al. 2002).

Perennial flow at the Tumacácori unit is augmented by treated wastewater discharges from the Nogales International Wastewater Treatment Plant. The perennial water supports a cottonwood-willow gallery forest at the
Tumacácori unit. Mesquite bosque (forest), xeroriparian scrubland, and semi-desert grassland bound these mesic forests. The riparian area is habitat for a number of rare or federally listed animals such as the Gila topminnow (Chapter 4) and yellow-billed cuckoo (Chapter 6, Powell 2000).

\section{Physiography and Geology}

The Upper Santa Cruz River Valley is located in the southern Basin and Range Province of southeastern Arizona and northern Sonora. This terrain of alternating fault-bounded linear mountain ranges and sediment-filled basins began to form in southeastern Arizona as the result of dominantly east-northeast/westsouthwest directed crustal extension.

The mountain ranges (Santa Rita, San Cayetano, and Patagonia) to the east of the park consist of a variety of rocks, including igneous, metamorphic, volcanic, and sedimentary, ranging in age from Precambrian to Miocene. The Tumacácori and Atascosa Mountains west of the park are composed chiefly of Tertiary volcanic rocks with the exception of a Jurassic granitic pluton south of Sopori Wash at the northern end of the Tumacácori Mountains. The Pajarito Mountains at the southern end of the valley, west of Nogales, are composed of Cretaceous volcanics.

\section{Hydrology and Soils}

Basin-fill sediments along the Santa Cruz River, north of the City of Nogales to Amado, form three aquifer units: Nogales Formation, Older Alluvium, and Younger Alluvium (ADWR 1999). The floodplain alluvium of the Santa Cruz River increases in width from about 1.3 to $1.9 \mathrm{~km}$ between the Nogales International Wastewater Treatment Plant and the Tumacácori unit (including the Guevavi unit) and averages about $2.4 \mathrm{~km}$ wide between Josephine Canyon and Amado (including the Tumacácori unit) (ADWR 1999). In the vicinity of all the park units the soils are 


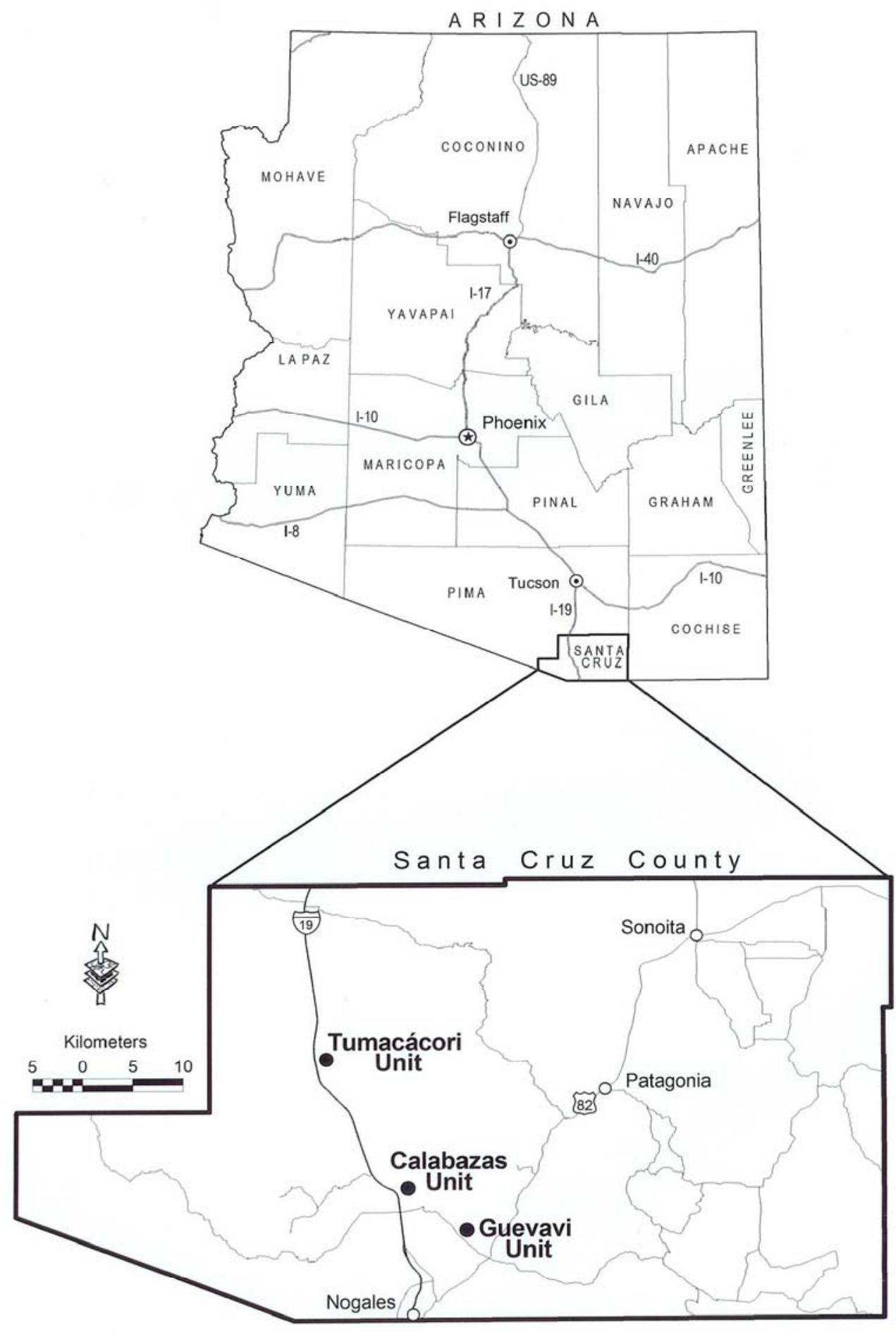

Figure 2.1. Locations of the three units of Tumacácori NHP in southern Arizona. 


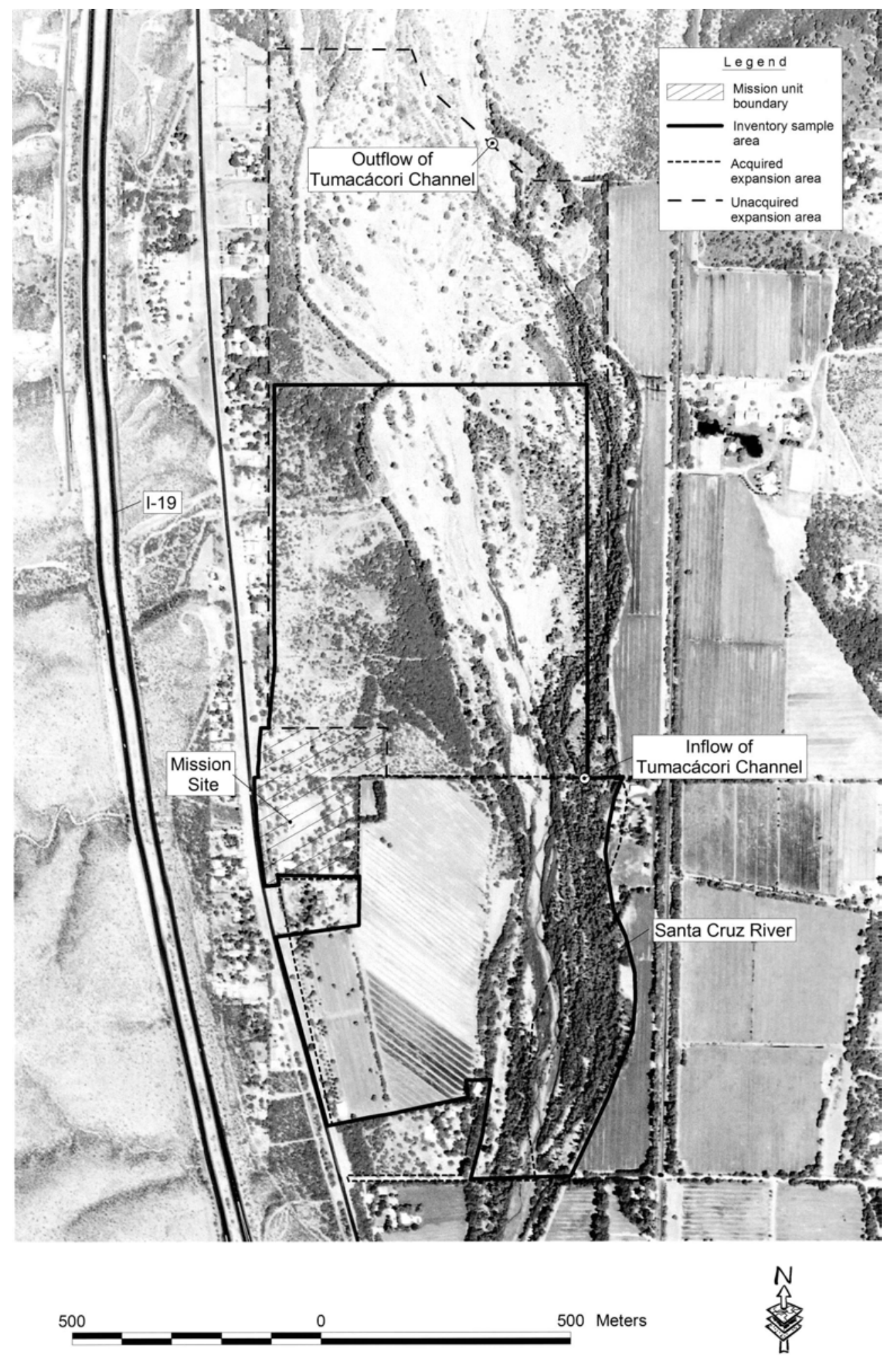

Figure 2.2. Aerial photograph of the study area and park boundary, Tumacácori unit, Tumacácori NHP. 

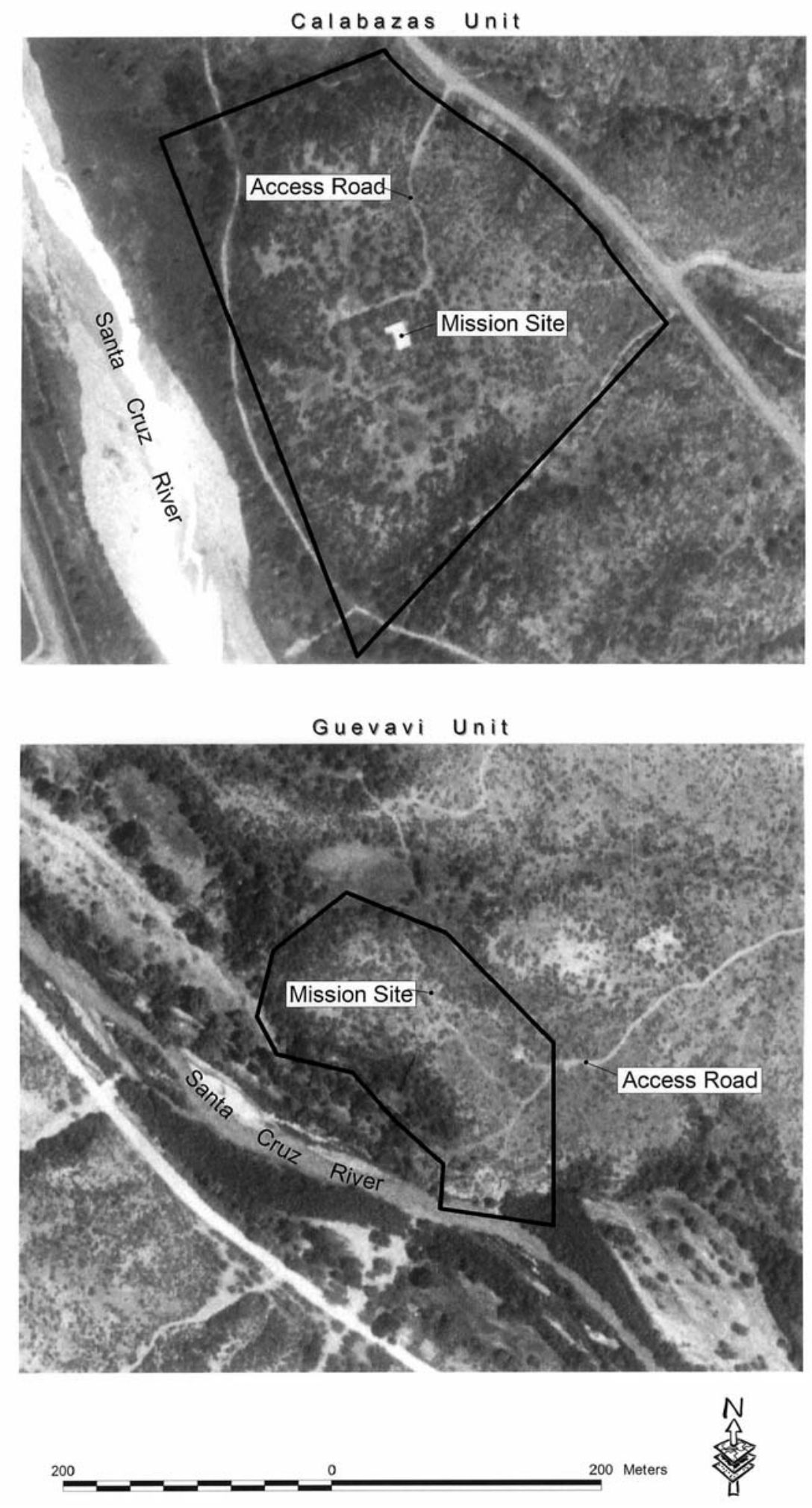

Figure 2.3. Aerial photographs of the Calabazas and Guevavi units, Tumacácori NHP. 
typical of floodplains, alluvial fans, and valley slopes of this semi-desert region; they are deep and well drained, with a high water-holding capacity (NPS 1996).

\section{Climate}

Tumacácori NHP is located within the semidesert climatic zone of southern Arizona, which is characterized by heavy summer (monsoon) storms brought about by moisture coming from the Gulf of Mexico and less intense, frontal storms from the Pacific Ocean in the winter. Approximately half of the annual precipitation falls from July to September (Table 2.1) (WRCC 2004). The area's hot season occurs from April through October; maximum temperatures in July often exceed $40{ }^{\circ} \mathrm{C}$. Intense surface heating during the day and active radiant cooling at night can result in daily temperature ranges of $17^{\circ}$ to $22^{\circ}$ C. Winter temperatures are mild. Prevailing winds tend to follow the Santa Cruz Valley, blowing downslope (from the south) during the night and early morning, and upslope (from the north) during the day.

Weather during the three years of this study was highly variable and atypical (Fig. 2.4). Annual total precipitation ranged from slightly greater than average in $2000(48.8 \mathrm{~cm})$ and $2001(42.2 \mathrm{~cm})$ to one of the driest years on record in 2002 (23.6 cm; Fig. 2.4). Annual mean temperatures were above the long-term mean $\left(17.7^{\circ} \mathrm{C}\right)$ in 2000 and $2002\left(18.0^{\circ} \mathrm{C}\right.$ in both years) and below it in $2001\left(17.4^{\circ} \mathrm{C}\right)$ (WRCC 2004).

\section{Vegetation}

All three units have vegetation typical of the semi-desert grassland association (Brown et al.
1979, Brown and Lowe 1980). Common species include velvet mesquite, foothills palo verde and species of acacia, wolfberry, and greythorn, annual and perennial grasses, and forbs (NPS 1996). At the Tumacácori unit, in particular, there are dense stands of mesquite bosque and gallery riparian vegetation. Velvet mesquite, netleaf hackberry, and Mexican elderberry are common in the mesquite bosque areas, whereas in the mesic riparian areas, Fremont cottonwood, Goodding's willow, tamarisk, and Arizona walnut form dense and structurally diverse stands of vegetation, particularly adjacent to surface water.

\section{Natural Resource Management Issues}

Because of its location along a river corridor, its proximity to the border with Mexico, and its diversity of biotic communities, Tumacácori NHP has many natural resource management issues that deserve attention. Here we review some threats to the unique natural resources at the park. For a more detailed analysis of some species mentioned in this section refer to the Discussion section of the appropriate chapter.

\section{Adjacent Development}

The boundaries of the Tumacácori unit are near the town of Tubac (to the north) and the Rio Rico development (to the south). The population of Rio Rico is expected to increase three-fold by 2025 (ADWR 1999) and Tubac is rapidly expanding as well. Much of the remaining undeveloped land adjacent to the park is currently used for irrigated agriculture or livestock grazing but additional residential development has been proposed (Ann Rasor, pers. comm.). Similarly, increased residential development is taking place near the Calabazas

Table 2.1. Average monthly climate data for Tumacácori NHP, 1948-2003 (data from WRCC 2004).

\begin{tabular}{lrrrrrrrrrrrrr}
\hline & \multicolumn{10}{c}{ Month } & \\
\cline { 2 - 10 } Characteristic & Jan & Feb & Mar & Apr & May & Jun & Jul & Aug & Sep & Oct & Nov Dec & Annual \\
\hline Maximum temperature $\left({ }^{\circ} \mathrm{C}\right)$ & 19 & 21 & 23 & 27 & 32 & 37 & 36 & 34 & 34 & 29 & 23 & 19 & $\mathbf{2 8}$ \\
Minimum temperature $\left({ }^{\circ} \mathrm{C}\right)$ & 0 & 1 & 3 & 5 & 9 & 14 & 19 & 18 & 15 & 9 & 3 & 1 & $\mathbf{8}$ \\
Precipitation $(\mathrm{cm})$ & 2.5 & 2.3 & 2.3 & 0.8 & 0.5 & 1.3 & 9.9 & 9.7 & 3.8 & 2.8 & 1.8 & 3.3 & $\mathbf{3 . 4}$ \\
\hline
\end{tabular}



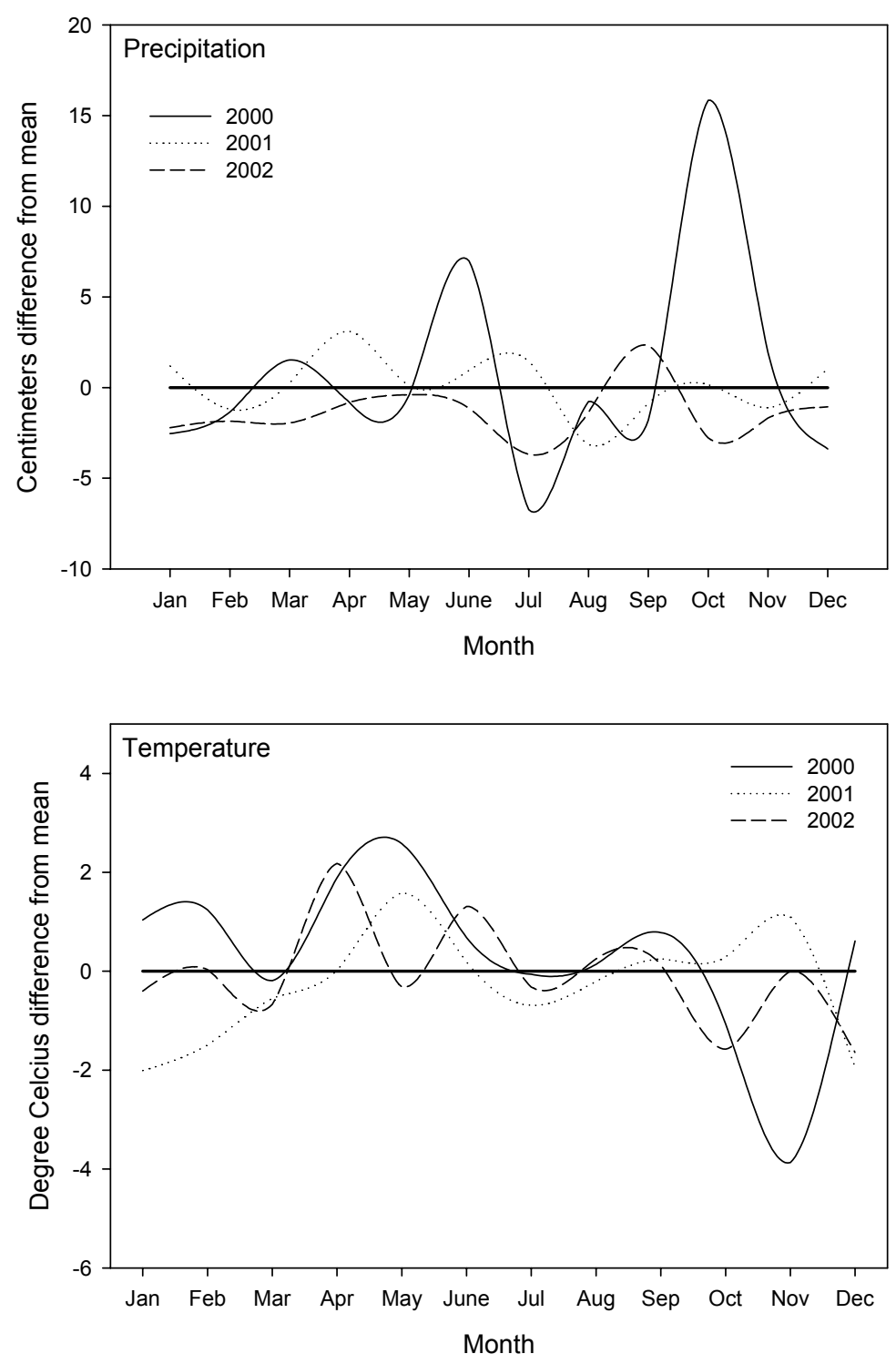

Figure 2.4. Comparison of monthly weather data during the time of the inventory (2000-2002) compared to the mean (1948-2004; thick solid line in both figures), Tumacácori NHP (data from WRCC 2004).

unit, which is close to ex-urban sprawl from the City of Nogales, Arizona.

\section{Water Quality}

The following information on water quality is summarized from Sprouse et al. (2002) and King et al. (1999). Given the park's location along the Santa Cruz River, the quantity and quality of surface water are important concerns at the park, particularly at the Tumacácori unit, which now includes a portion of the river. The other two units are influenced by proximity to the river (e.g., occurrence of mesic riparian vegetation and possible presence of semiaquatic animals in each unit), though neither area includes permanent flow.

Effluent from the Nogales International Wastewater Treatment Plant (NIWTP), located $14 \mathrm{~km}$ upstream from the Tumacácori unit and across the river from the Calabazas unit, has a 
significant impact on both water quality and quantity at the Tumacácori unit. Treated effluent provides perennial surface flow for more than $15 \mathrm{~km}$ of the Santa Cruz River in an area that would otherwise be dry much of the year.

Countering the benefits from the presence of the effluent, there are a number of water quality problems that affect park resources. Water samples from the Calabazas Road Bridge (located between the Tumacácori and Calabazas units) have included twenty-two groups of parameters that exceeded National Park Service Water Resources Division screening criteria (NPS 2001). In addition, dissolved oxygen, $\mathrm{pH}$, chlorine, cyanide, cadmium, copper, lead, mercury, selenium, silver, and zinc exceeded respective U.S. Environmental Protection Agency (USEPA) criteria for the protection of freshwater aquatic life (ADEQ 2000, USEPA 2001). Nitrate, arsenic, barium, cadmium and chromium exceeded USEPA drinking water criteria (ADEQ 2000, USEPA 2001), fecal-indicator bacteria concentrations (total coliform and fecal coliform) exceeded Water Resources Division screening limits for freshwater bathing, and turbidity measurements exceeded Water Resources Division limits deemed safe for aquatic life (ADEQ 2000, NPS 2001). The ADEQ has categorized the water in the Santa Cruz River as "impaired" due to turbidity at the Guevavi unit and impaired due to fecalindicator bacteria concentrations along stretches adjacent to both the Calabazas and Tumacácori units (ADEQ 2000).

High levels of chromium (metal) and DDE (dichlorodiphenyldichloroethylene; organochlorine compound) were present in animals collected from the Santa Cruz River during a 1999 study (King et al. 1999).

Almost half of the invertebrate samples in this study contained concentrations of chromium that could be harmful to higher-trophic-level organisms, and four of eight killdeer carcasses contained DDE levels that are associated with impaired reproduction and may also pose a bio-accumulation risk to predators (King et al. 1999). Perhaps the issue of greatest concern is the presence of toxic levels of un-ionized ammonia in sampling locations downstream from the treatment plant. High concentrations of ammonia were documented by five studies between 1995 and 1999, and have been identified as responsible for fish mortality (summary in King et al. 1999). A high proportion of fish collected downstream from the treatment plant also possessed physical anomalies of unknown cause (King et al. 1999).

Although levels of ammonia decreased with distance from the treatment plant, the toxicity of water upstream of the Tumacácori unit may dramatically reduce the likelihood that additional native aquatic or semi-aquatic animals will colonize that area from upstream locations. Indeed, in an earlier study, researchers noted that despite presence of five species of amphibian upstream from the treatment plant, “... no amphibians are found along the river from the waste water outfall downstream for several kilometers" (Drost 1998).

The river is also vulnerable to releases of raw sewage from the NIWTP, whether from a break in the main sewer line (which occurred in 1977; NPS 1993) or from periodic surges in the volume of raw sewage coming into the plant, thereby overwhelming the facility (Sprouse et al. 2002). Increased treatment capacity is planned for the plant (which would improve its ability to handle surges; Terry Sprouse, pers. comm.) and installation of pretreatment equipment would reduce ammonia concentrations to non-toxic levels. These improvements were initially scheduled for completion by March 2002 (King et al. 1999) but at the time of this writing (April 2005) they had not begun.

\section{Riparian Vegetation}

Regardless of the concerns regarding contamination, the water from NIWTP has resulted in the extensive cottonwood-willow riparian community at the Tumacácori unit and adjacent lands. Loss of those waters due to a proposed treatment plant in Nogales, Sonora, 
could result in the degradation of the diverse riparian area at the park.

Riparian plant communities in the southwestern United States account for less than $1 \%$ of the landscape cover (Skagen et al. 1998), yet it is estimated that greater than 50\% of southwestern bird species (Knopf and Samson 1994) and up to $80 \%$ of all wildlife species in the southwest are dependent on riparian areas (Chaney et al. 1990). Riparian areas in arid regions support high bird species diversity due their structural and floristic diversity as compared to surrounding areas (Thomas et al. 1979, Lee et al. 1989, Strong and Bock 1990) that translates into abundant insects for foraging and large trees for nesting (Powell and Steidl 2000). Riparian vegetation, such as cottonwoods, willows, and ash have been found to decrease levels of heavy metals in water and soil in addition to decreasing water temperatures, providing a source of organic matter, and stabilizing stream banks (Karpiscak et al. 2001, Karpiscak et al. 1996, Osborne and Kovacic 1993). The Bureau of Land Management estimates that less than $20 \%$ of the western United States' potential riparian vegetation remains to perform these vital services (BLM 1994). Such loss highlights the importance of maintaining these rare riparian plant communities along the Santa Cruz River.

\section{Off-road Vehicles}

Park staff and adjacent landowners prohibit off-road vehicles in the Santa Cruz River floodplain, but trespass is frequent, particularly at the Tumacácori unit where flood events wash out fencing (Roy Simpson, pers. comm.). Off-road vehicles cause soil compaction (Wilshire 1983) and erosion by damaging and destroying vegetation (Johnson and Smith 1983). They also affect wildlife through direct mortality and habitat destruction (e.g., crushed burrows; Wilshire 1983, Brotons and Herrando 2001).

\section{Non-native Species}

Awareness of non-native species as a management issue has risen dramatically in recent years and ecologists have ranked it as one of the most significant causes of species endangerment (Brooks and Pyke 2001). Nonnative plant species are a significant management issue at the park, particularly at the Tumacácori unit, where invasives such as tamarisk, Bermudagrass, and Russian thistle are well established. Non-natives plants are known to alter ecosystem function and processes (Naeem et al. 1996, D'Antonio and Vitousek 1992) and reduce the abundance of native species, potentially permanently changing diversity and species composition (Bock et al. 1986, D'Antonio and Vitousek 1992, OTA 1993). The Tumacácori unit provides habitat for non-native vertebrates as well, including western mosquitofish, largemouth bass, bluegill, and sunfish (Chapter 4); American bullfrog (Chapter 5); house sparrow and European starling (Chapter 6); and cattle, and feral cats and dogs (Chapter 7).

\section{Impacts from Undocumented Immigrants}

The proximity of the park to the U.S.-Mexico border results in a number of unique management issues. The Santa Cruz River provides a well-known and well-used corridor for undocumented immigrants traveling north from Mexico, and much of this traffic passes through the Tumacácori unit (NPS 2003). Although visitor safety concerns have not yet become a significant issue, reported impacts to the park include erosion, compacted soils, and vandalism (NPS 1996). Other national parks in the border region have reported fire hazards, theft and destruction of historic resources, disruption of wildlife movements (including reduced access to water sources), reduced water quality, and closure of park attractions due to safety concerns (NPS 2003). To our knowledge only one (recently initiated) study is aimed at quantifying the effects of immigrants on animal communities in southern Arizona (O’Dell 2003; but see McIntyre and Weeks 2002).

\section{Trash Flows}

During heavy flooding events in the Santa Cruz River watershed, a large quantity of trash washes downstream, primarily from the 
Nogales (Portrero) Wash that originates in Sonora, Mexico. This trash often becomes trapped in a few locations, leading to large accumulations (Figure 2.5). Trash is principally of plastics such as water bottles but also includes batteries and tires. Park personnel and volunteers have done an excellent job of cleaning up a number of these sites in recent years, but the problem will likely continue.

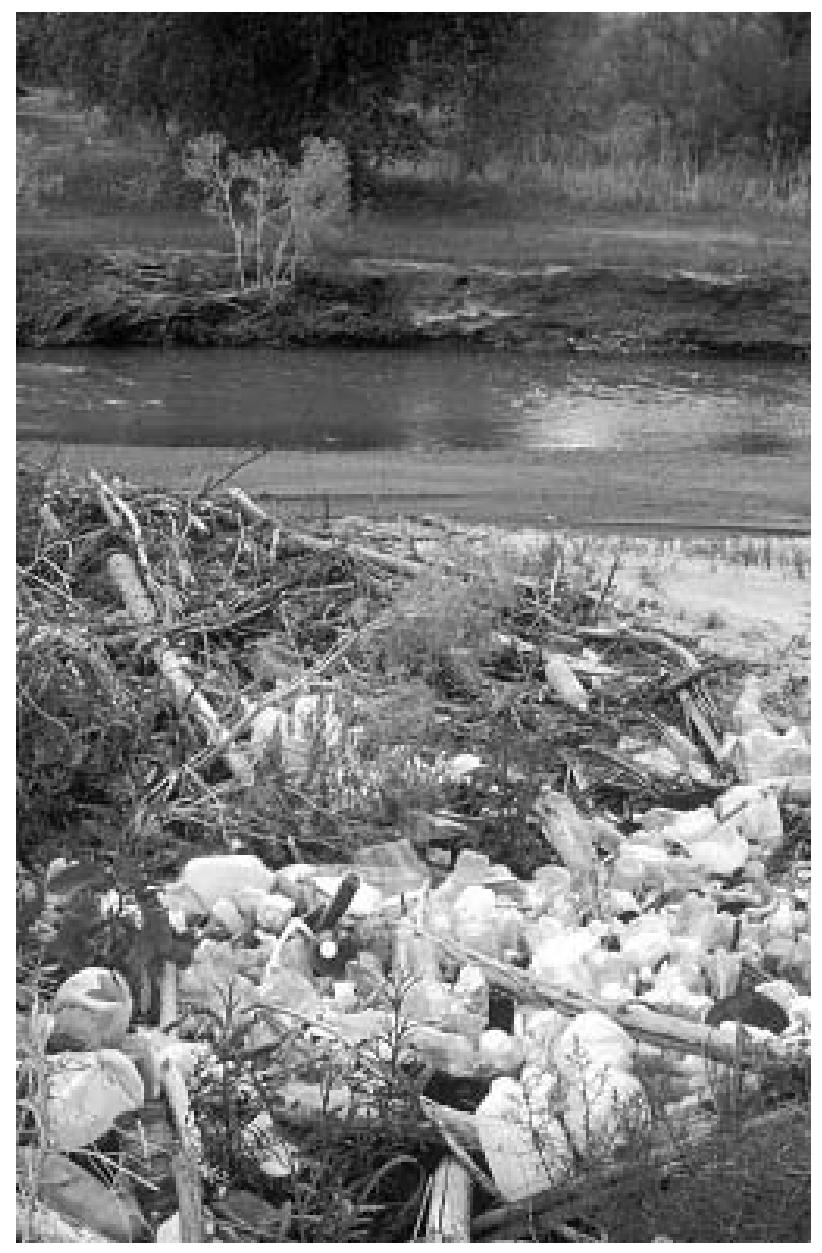

Figure 2.5. Trash accumulation along the Santa Cruz River, Tumacácori NHP, August 2002. 


\section{Chapter 3: Plant Inventory}

\section{Previous Research}

There have been two previous plant inventories at the Tumacácori unit. Mouat et al. (1977) recorded 130 species during seven survey days in the spring and summer of 1977. A less complete and poorly documented survey was conducted at the Tumacácori unit in the 1980s or 1990s (Bennett, year unknown). There are also 50 specimens from the park at the University of Arizona herbarium (Appendices A and F). To our knowledge, there were no prior plant inventories at either the Calabazas or Guevavi units.

\section{Methods}

Our surveys included both qualitative and quantitative methods: qualitative "general botanizing" surveys in which we opportunistically collected and recorded plants, and quantitative plot-based sampling which included three complementary methods to estimate abundance, percent cover by species, and species composition of all plants in a small area.

For this report, statistics such as the number of species collected or percentage of non-native species exclude records that we could not identify to species $(n=10$; e.g., Tithonia sp.) unless there were no other specimens identified to species for that genus ( $n=7$; e.g., Nandina sp.) (Appendix A). We recorded 11 species with $\geq 2$ subspecies and/or varieties (Appendix A), and we include all subspecies and/or varieties in our summary statistics of the number of "species" recorded. Counts include ornamental (i.e., planted) species $(n=$ $10)$, unless otherwise noted.

\section{Spatial Sampling Designs}

General botanizing surveys encompassed most areas within the park during most visits. For modular plots we used a simple random sampling design (Thompson 1992) to locate the southwest corner of 17 plots. The study area, from which we selected random points, covered approximately 111 ha (Fig. 3.1, Appendix J). When establishing plots on the ground we occasionally encountered obstacles (e.g., surface water, buildings) that prevented us from establishing a plot in the precise location specified. In this event we moved the plot, in most cases only a few meters from the original location and in a random direction. We also subjectively placed three plots in community types that we felt were not represented by one or more of the 17 other plots: one each in an agricultural field, in dense mesquite bosque, and in dense mesic riparian vegetation.

\section{General Botanizing}

\section{Field Methods}

We surveyed for plants from 2000 to 2003 and during multiple seasons to ensure that we encountered as many species as possible. General botanizing surveys during 2000 and 2001 included only the area within the original unit boundaries, but later surveys included the expansion area of the Tumacácori unit.

Whenever possible we collected one representative specimen (with reproductive structures) for each plant species in each park unit. We also maintained a list of species observed but not collected within each unit. These lists, along with the list of collected species, comprise a "flora" for each unit (Appendix A). When we collected a specimen, we assigned it a collection number and recorded the flower color, associated dominant vegetation, date, collector names, and UTM coordinates. We pressed and processed the specimens on site. Specimens remained pressed for 2-3 weeks and were later frozen for 48 hours or more to prevent infestation by insects and pathogens. We accessioned mounted specimens into the University of Arizona herbarium. 


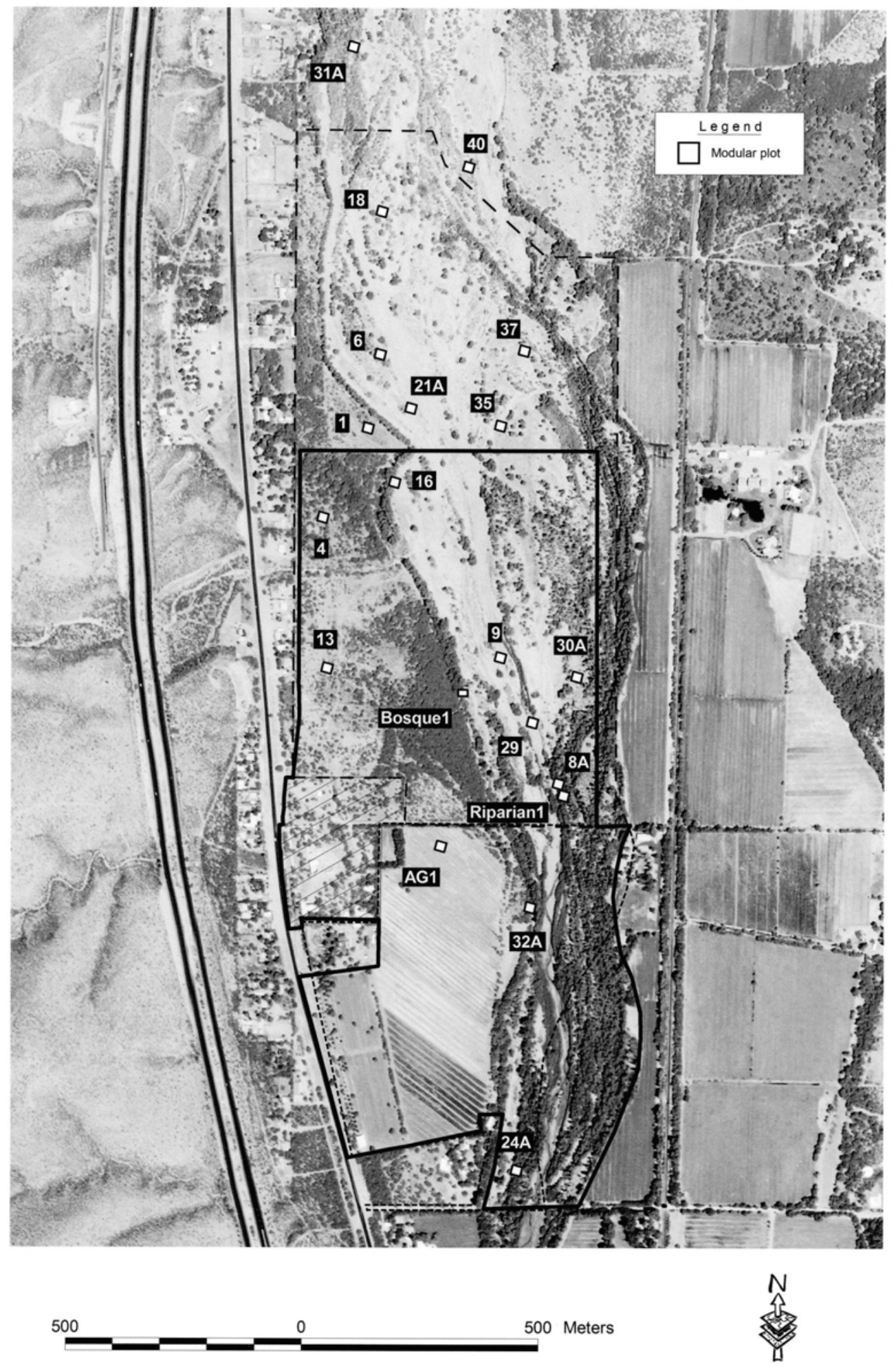

Figure 3.1. Locations of modular plots for plants, Tumacácori unit, Tumacácori NHP, 2002. See Appendix $\mathrm{J}$ for plot coordinates. 
Effort

We made 17 general botanizing visits (typically one observer for one-half day) within the original Tumacácori unit boundary, 12 visits to the expansion lands (typically two observers for one day), and 14 and 15 visits to the Calabazas and Guevavi units, respectively (typically one observer for one-half day at each unit). From August 2000 to October 2001, we surveyed approximately monthly within the original boundaries of all units. In 2002 (September and October) and 2003 (April and May) we expanded surveys to include areas within the expansion lands of the Tumacácori unit. Visits were more frequent from April through October to maximize opportunities for collecting specimens with reproductive structures (i.e., flowers or fruits).

\section{Analysis}

We present a variety of summary statistics: total number of species found by location and day of sampling, and number and percent of native and non-native species. To estimate inventory completeness we graph the number of new species by sampling event, which we randomized to account for seasonal differences in numbers of new species (e.g., we recorded a high number of new species after the summer monsoons and a low number of new species during the winter months).

\section{Modular Plots}

We performed modular plot fieldwork in cooperation with NPS Sonoran Desert Network staff who used the protocol (Peet et al. 1998) in multiple NPS units (e.g., Drake et al. 2003). The modular plot fieldwork reported here is part of that long-term vegetationmonitoring program, and these results may serve as a baseline to assess changes in the vegetation community at the Tumacácori unit.

\section{Field Methods}

We used a standardized, plot-based approach at the Tumacácori unit in November 2002. The basic unit was the $10 \times 10 \mathrm{~m}$ module, two or four of which were joined to create a plot, measuring either $10 \times 20 \mathrm{~m}$ or $20 \times 20 \mathrm{~m}$ (Fig. 3.2). We used two types of sampling at modular plots, each method with different objectives: (1) point-intercept transects to estimate species frequency and ground cover and (2) nested plots (similar to Braun-Blanquet plots [Braun-Blanquet 1965]), to estimate percent cover for all plants as well as basalarea measurements for large woody plants.

We sited plots as follows: navigated to the northwest corner of each plot using Emap GPS units; marked the corner with a permanent rebar stake; used a compass and tape measure to define remaining module corners; and used a Pathfinder GPS unit to obtain accurate UTM coordinates for the point. We aligned plot boundaries in cardinal directions (e.g., the west boundary was along a north-south line). All plots were in a $2 \times 2$ module arrangement (Fig. 3.2) with the exception of one $1 \times 2$ module arrangement ("Bosque 1").

\section{Point-intercept Transects}

We bisected each module with a north-south transect (Fig. 3.2) that was established using a $10-\mathrm{m}$ tape measure marked at $10-\mathrm{cm}$ increments. In each of three height categories $(<0.5 \mathrm{~m}, 0.5-2 \mathrm{~m}$ and $>2 \mathrm{~m})$ we recorded the first species to be intercepted by a vertical line (created using a laser pointer), at each of 100 points located every $10 \mathrm{~cm}$ along the transect line. If no plant was encountered we recorded "no plant." We classified ground cover at each point according to the following categories: bare soil, loose rock, bedrock, or litter (senescent plant material that was detached from plants).

\section{Braun-Blanquet Plots}

We used a form of the Braun-Blanquet method (Braun-Blanquet 1965) to estimate percent cover (area covered by each plant species as viewed from above) for each species on all modules and quadrats in each of the height categories used for point-intercept transects. We estimated coverage at two scales: large (10 x $10 \mathrm{~m}$; covering the entire module; $n=2$ or 4 per plot) and small (1 x $1 \mathrm{~m}$ quadrats; in opposite corners of each module; $n=4$ or 8 quadrats per plot) (Fig. 3.2). 


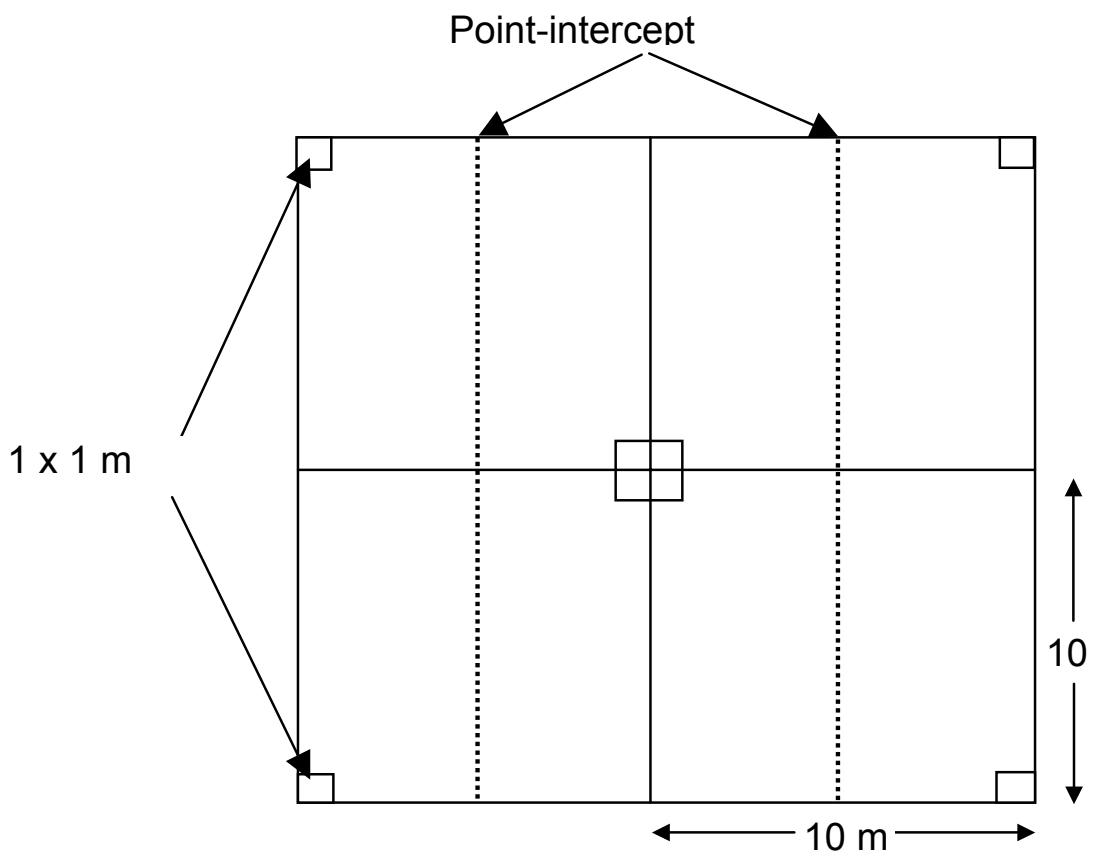

Figure 3.2. Typical modular plot layout of four $10 \times 10 \mathrm{~m}$ modules, eight $1 \times 1 \mathrm{~m}$ quadrats, and four $10-\mathrm{m}$ point-intercept transects, Tumacácori unit, Tumacácori NHP, 2002.

To estimate percent cover in each height category for each plant species, we assigned the total coverage by each species to one of six cover classes based on visual estimation: "trace" (< 1\%), "1" (1-5\%), "2" (6-25\%), “3" (26-50\%), "4" (51-75\%), or "5" (76-100\%).

Because quadrats were nested within modules (Fig. 3.2), modules always contained all the plant species that were recorded in the quadrats. We recorded tree species in each module if the majority of the trunk was inside the module, and recorded basal diameter if it was $>15 \mathrm{~cm}$. For stems $<15 \mathrm{~cm}$ basal diameter, we counted the number for each species but did not record basal diameter.

\section{Effort}

Four observers measured vegetation on 20 plots at the Tumacácori unit during ten field days from 2 to 17 November 2002. Nineteen plots had four modules in a $20 \times 20 \mathrm{~m}$ arrangement (Fig. 3.2) and one plot had two modules in a $20 \times 10 \mathrm{~m}$ arrangement $(n=78$ modules).

\section{Results}

We recorded 378 species during general botanizing and modular plot surveys from 2000 to 2003 (Appendix A). We recorded the most species at the Tumacácori unit $(n=293)$. We recorded fewer species at the Calabazas ( $n$ $=175)$ and Guevavi units $(n=151)$. The most common families were composites

(Asteraceae), grasses (Poaceae) and legumes (Fabaceae). More than $82 \%$ of the remaining families were represented by three or fewer species, a pattern consistent with floras of nearby areas (McLaughlin et al. 2001).

We recorded 67 non-native species in all units combined (Appendix A). Excluding ornamentals, the percentage of non-native species averaged $15 \%$ among park units but varied considerably: the highest percentage of non-native species was at the Tumacácori unit $(18 \% ; \mathrm{n}=52)$, a lower percentage at the Guevavi unit $(11 \% ; n=17)$, and the lowest percentage at the Calabazas unit $(9 \% ; n=16)$ (Appendix A). Considering all units, the grass family (Poaceae) had the highest percentage of 
non-native species $(33 \% ; n=22)$. Perhaps the most notable non-native species we

documented was the muster John Henry (at the Tumacácori unit); this was the second documentation of its occurrence in Arizona.

\section{General Botanizing}

\section{Tumacácori Unit}

We recorded 191 species (representing 58 families) in the original Tumacácori unit boundaries and an additional 62 species (7 families) in the expansion area (Appendix A). We collected specimens at 139 sites: 102 near the Mission and 37 in the expansion area.

Calabazas Unit

We recorded 175 species and collected specimens at 74 sites (Appendix A).

Guevavi Unit

We recorded 151 species and collected specimens at 58 sites (Appendix A).

\section{Modular Plots}

We recorded 93 species in 20 plots at the Tumacácori unit (Appendix A, Q, R). The mean number of species per plot was 18.4 $( \pm 1.3 \mathrm{SE}$, range $=8$ to 30$)$ (Appendix Q). Over one-third of the species $(n=33)$ were found on only one plot, and five species (including the non-native

Bermudagrass) were found on $\geq 75 \%$ of the plots (Appendix R). Fourteen percent $(n=13)$ of the species were non-native, and of these more than half were grasses (Appendix A).

\section{Comparison of Braun-Blanquet Plots and Point-} intercept Transects

For all height classes, only 55\% $(n=51)$ of the 93 species recorded on Braun-Blanquet plots were also recorded on point-intercept transects (Appendix R). There were also substantial differences in the frequency of species detections between the two methods; of the 24 species recorded in $>1$ plot (using both methods), all but one were recorded more often in Braun-Blanquet plots than on pointintercept transects. We recorded the 13 most common species (those recorded on $\geq 40 \%$ of plots) on a mean of $48 \%( \pm 7.5 \mathrm{SE})$ more plots than the same species were recorded along transects. Velvet mesquite, the most frequently recorded species along transects, ranked sixth in percent cover using the BraunBlanquet method while carelessweed (ranked first in percent cover Braun-Blanquet plots), ranked fourth in frequency along transects. The abundance rank of the most common nonnative species changed little based on the method used; Bermudagrass was recorded in 17 of the 20 plots by both methods and ranked sixth and seventh in dominance according to transects and Braun-Blanquet plots, respectively.

\section{Pima Pineapple Cactus and Huachuca Water Umbel}

We searched for two endangered species thought to be in the area: Pima pineapple cactus (Coryphantha scheeri var. robustispina) and Huachuca water umbel (Lilaeopsis schaffneriana var. recurva), but did not find either.

\section{Inventory Completeness}

Other researchers listed 46 species at the Tumacácori unit that we did not find (Appendix F). While these may still be present and we missed them, alternative explanations include misidentification (many previous records were not documented), local extirpation, and use of different field methods. Judging from the presence of conspicuous perennial species at both the Calabazas and Guevavi units but not Tumacácori unit (e.g., whitethorn acacia), some local extirpation may have occurred. Ornamental species that we did not find such as myrtle, Japanese privet, Chinese firethorn and garden tomato were probably used in landscaping around park buildings and died or were removed without replacement.

Species accumulation curves for general botanizing (Fig. 3.3) and modular plots (Fig. 3.4) show little sign of reaching asymptotes. Yet, taken together the general botanizing and modular plot work produced a high number of species for the park (see Discussion section). 
We recorded plants over three years and during periods of average rainfall, thereby making it possible that we recorded $90 \%$ of the species. However, in order to confirm the completeness of our surveys it will be necessary to repeat our effort, particularly during spring and postmonsoon periods following above-average rainfall.

\section{Discussion}

Three factors likely contributed to our finding twice the number of species reported by previous studies (Mouat et al. 1977; Bennett year unknown): (1) our field effort was more than twice that of previous studies, (2) our survey area was larger (111 ha including the expansion area versus seven ha at the Tumacácori unit), and (3) we likely benefited from a winter (2000) that had more precipitation than average. This unusual weather probably enhanced recruitment of winter annuals, resulting in higher species richness of annuals during our fieldwork than during sampling by Mouat et al. (1977).

To develop a context for the species richness at Tumacácori NHP, we compared our results to the nearby flora of the Appleton-Whittell Research Ranch near Elgin in the Sonoita Valley (McLaughlin et al. 2001). This flora was comprised of approximately 345 species in an area about 30 times larger than Tumacácori NHP, yet species richness $(n=$ 368 not including ornamental species) in all three units of Tumacácori NHP was greater than at the Appleton-Whittell Research Ranch.

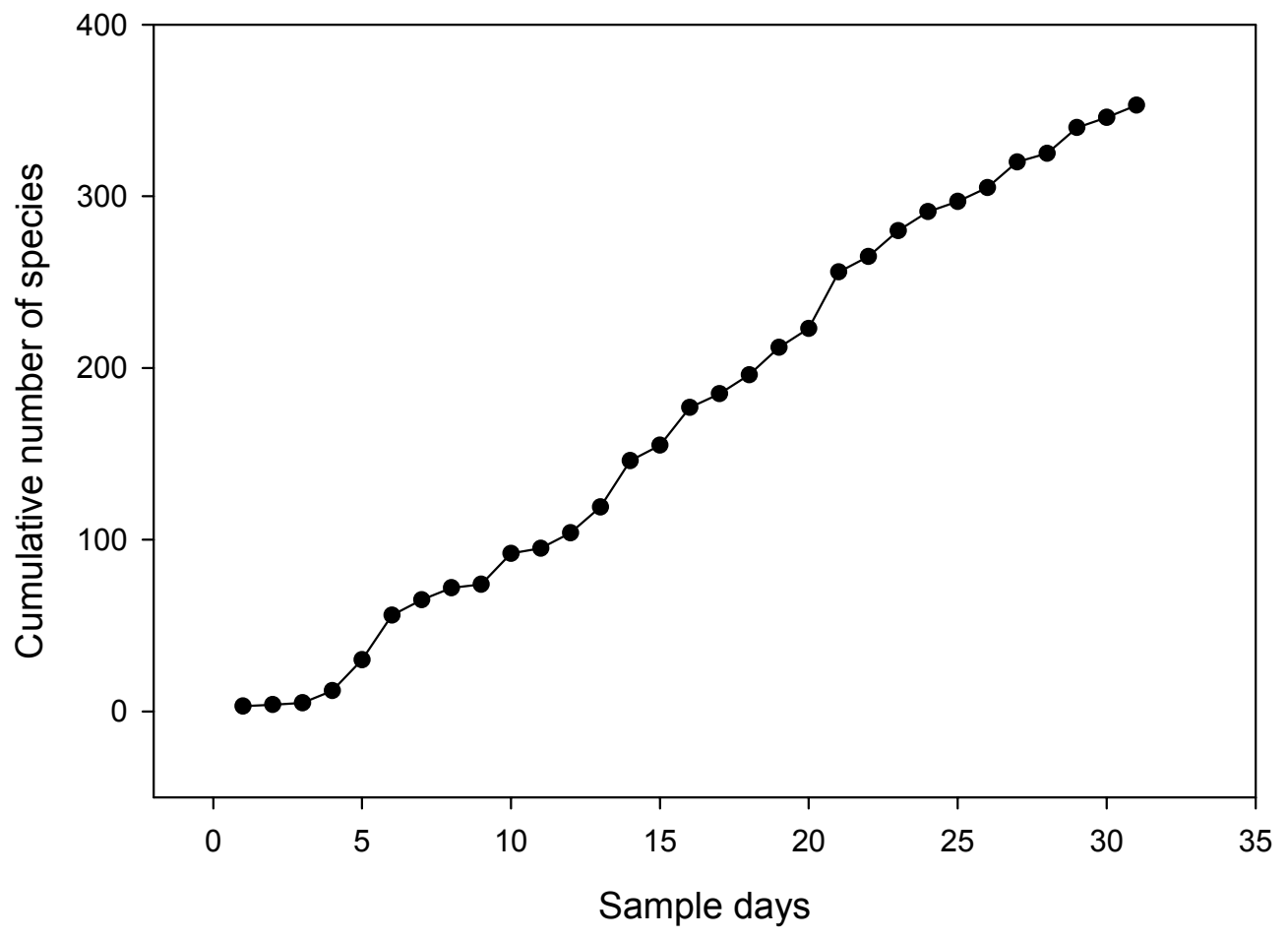

Figure 3.3. Species accumulation curve for cumulative number of new plant species collected as a function of the number of sample days, general botanizing and modular plot surveys, all units, Tumacácori NHP, 2000-2003. Order of sampling days was randomized to account for seasonal spikes in new plant species (e.g., post-monsoon season). 

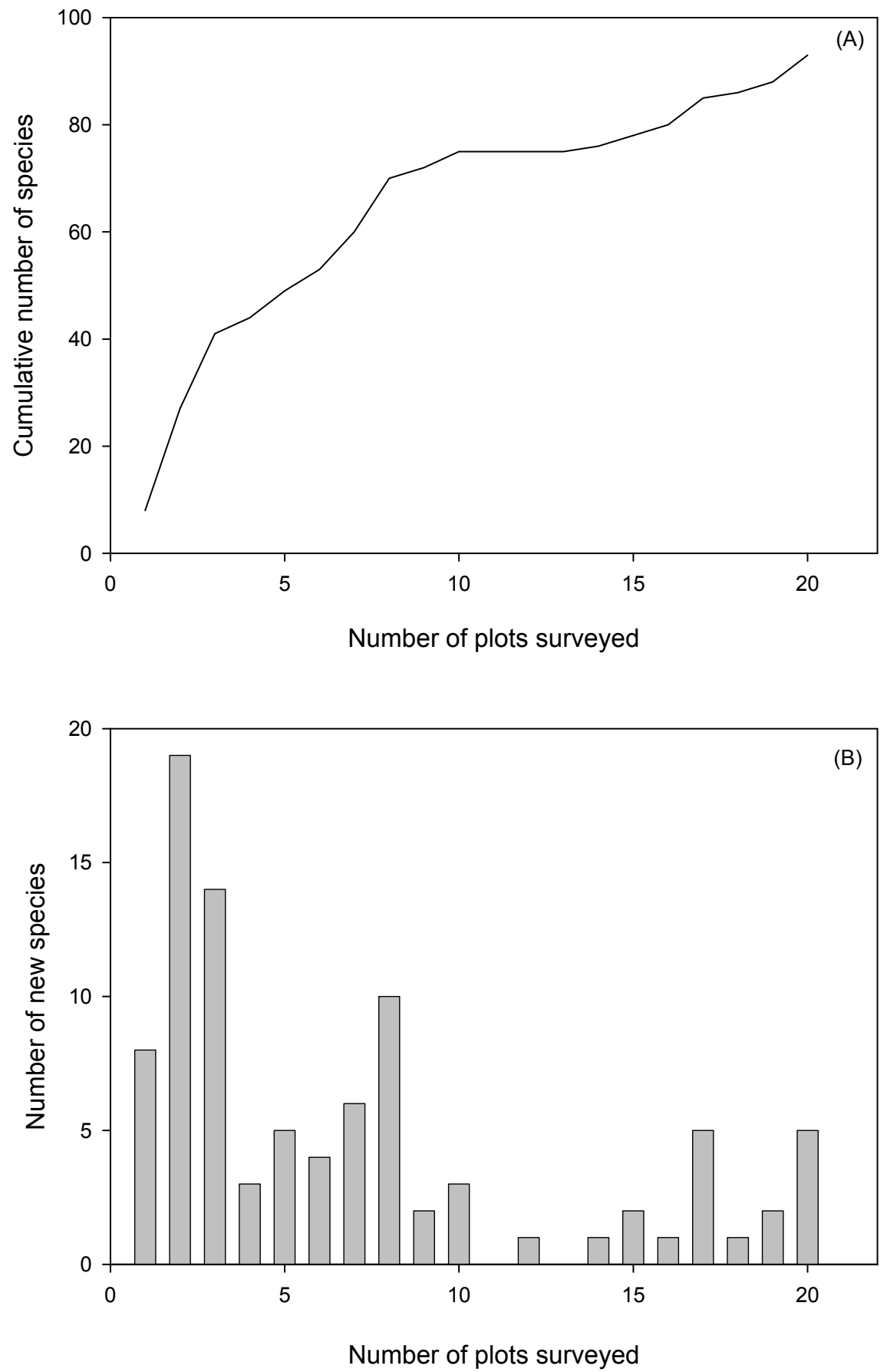

Figure 3.4. Cumulative $(A)$ and number of new plant species $(B)$ recorded as a function of the number of modular plots surveyed, Tumacácori unit, Tumacácori NHP, 2002. 
The higher number of recorded species at the Tumacácori unit compared to the other units of the park may be due not only to the larger sample area (about $128 \mathrm{ha}$ ), but also to differences in environmental conditions. The Tumacácori unit contains both xeric and mesic riparian areas, mesquite bosque, semi-desert grassland and landscaped areas, some of which provide habitat for species not recorded at the Calabazas or Guevavi units. Typical shrubinvaded semi-desert grassland present at the Calabazas and Guevavi units is less species rich, but these areas possess a surprising number of species for their size.

One notable difference among the units is that Calabazas and Guevavi units currently experience less disturbance than the Tumacácori unit; they are closed to the general public, are less subject to seed dispersal from the Santa Cruz river flow, and are less subject to ongoing disturbances (e.g., construction, grazing, flood events). These factors may explain why the floras of these units possess a lower percentage of non-native species and why they retain species that were historically recorded but no longer occur at the Tumacácori unit such as Takhoka-daisy, whitethorn acacia, and erect dayflower (Appendix A). Of the three units, Tumacácori appears to be the most highly affected by human activity. The unit hosts the park visitor center, offices, residential buildings, and maintenance compound. It has many unsurfaced utility roads and walkways, and receives many visitors. Of the 67 non-native species we recorded at the Tumacácori unit, 42 were not recorded by previous researchers (Appendix A). Many of these non-native species are winter annuals that may not have germinated following below-average winter rainfall preceding the survey of Mouat et al. (1977), though it should be expected that new non-native species might have colonized Tumacácori unit in the years since that study.

Excluding ornamental species (though these were present in previous surveys as well), the percent of non-native species averaged $15 \%$ among units (Appendix A). The percentage of non-native species in floras of southern
Arizona varies greatly among areas; Felger (1990) considers a non-native species richness component of $5-10 \%$ to be "healthy" though other factors must be taken into consideration in assessing the impacts of non-native species. These factors include whether each species has a high potential for increased distribution or community dominance; potential for disrupting nutrient cycling, fire regimes, or other ecological processes; and whether they are easily controlled. Notable for our surveys is the second verified record in Arizona of the muster John Henry. It was found in the understory of the cottonwood-willow forest east of the Santa Cruz River southeast of the mission, but not at the Calabazas or Guevavi units. It is considered a noxious weed in California (California Department of Food and Agriculture 2004). Once well established, a number of non-native species pose a significant management problem. Prominent species include tamarisk, Bermudagrass, Lehmann lovegrass, Johnsongrass, Russian thistle, London rocket, and yellow sweet clover. Bermudagrass, in particular, is difficult to control and was recorded in $85 \%$ of the modular plots (Appendices Q, R). A complete description of these non-native species as well as their life history, threat to native species, and eradication method(s) can be obtained from (Halvorson and Guertin 2003). 


\section{Chapter 4: Fish Inventory}

\section{Previous Research}

Arizona Game and Fish Department personnel completed periodic surveys of the Santa Cruz River, in or near Tumacácori NHP, between 1998 and 2001, in 2003, and one survey in the Tumacácori Channel in 1999 (Voeltz and Bettaso 2003).

\section{Methods}

We surveyed for fish at two sites at the Tumacácori unit: the Santa Cruz River and the Tumacácori Channel (previously referred to as "Cosper Slough" by Powell et al. [2002, 2003]). The channel is an abandoned meander that maintains its downstream connection with the Santa Cruz River. Alluvial groundwater seeping into the channel forms a short tributary stream and may be similar to the original "Tumacácori Spring" (Larry Martin, hydrologist, National Park Service, Ft. Collins, $\mathrm{CO}$ ). We surveyed the river from $30 \mathrm{~m}$ downstream of the confluence with the channel to about $25 \mathrm{~m}$ south of Santa Gertrudis Lane

(Fig. 2.2).

\section{Spatial Sampling Design}

For each sampling event (i.e., day) we surveyed up to one-half of the channel or river in our study area by surveying in a subjectively determined length of reach then skipping a similar length of reach. One-half of each reach was the maximum length that could be surveyed in a single sampling event.

\section{Field Methods}

Our field crew captured fish using two methods: (1) electrofishing (Dauble and Gray 1980) with a Smith-Root backpack unit in both areas (12-B POW; Smith-Root, Inc., Vancouver, WA; set to: DC pulse width of 60 $\mathrm{Hz}$, frequency of $6 \mathrm{~ms}$, voltage of $300 \mathrm{~V}$ ); and (2) dipnetting (long-handled dip nets with 4 mm mesh; Dauble and Gray 1980) in shallowwater areas of the channel. We identified captured fish to species, classified them as juvenile or adult according to relative size, sexed them when possible, and returned all fish to the same reach from which they were captured.

We randomly chose a bank of the river or channel from which to start surveys and proceeded upstream, concentrating on areas likely to shelter fish (e.g., stream margins and in-stream obstructions). We alternated banks and reaches of the river, sampling $100 \mathrm{~m}$ then skipping $150 \mathrm{~m}$ (i.e., surveying the east bank, skipping $150 \mathrm{~m}$, then surveying the west bank, and repeating). For the channel, we surveyed alternating $50 \mathrm{~m}$ reaches from the confluence with the river to the point of its origin (Fig. 2.2). We used electrofishing for the first 200 $\mathrm{m}$ (downstream) of the channel (which has relatively large and deep pools that allow shocking) and dip netting for the remainder of the channel.

\section{Effort}

Three to four field personnel surveyed the channel and river on four sampling periods (eight sampling events), once each in the spring and fall of 2001 and 2002 . We did not record sampling effort for individual reaches.

\section{Analysis}

Because we recorded total catch per sampling event (rather than by sampling within reaches), we were unable to apply statistical analyses to the data ( $n=1$ for each sampling event).

Therefore, we report data summaries: total catch per day, percent of total catch by species, and species richness by site. Because we did not subsample or account for detectability of each species, we cannot estimate population parameters (e.g., size). We do not differentiate juveniles and adults in our summaries because reliable aging methods are time-intensive (Bill Matter, pers. comm.). We compare sex ratios in Gila topminnow and western mosquitofish, species in which gender is easily determined. 


\section{Results}

\section{Species Richness}

We recorded eight species (four native, four non-native) and one hybrid (green sunfish/bluegill) at Tumacácori NHP (Table 4.1, Appendix B). We recorded all eight species on the first sampling event in the channel and Gila topminnow, longfin dace, and western mosquitofish in both sites on all sampling events (Table 4.1, Appendix S). Species richness in the channel was higher than in the river on all but the last sampling event (Fig. 4.1).

\section{Total Catch}

We captured a total of 3,329 individuals (Appendix S). Fifty-seven percent of captures were from the channel (Table 4.1). Total number of individuals caught per sampling event was lowest in the river in April 2001 (35 captures in one day) and highest in the river approximately one year later (722 captures in one day) (Fig. 4.1). Total number of captures at both sites was similar for each sampling event except November 2002 when we captured $75 \%$ fewer individuals in the river (Fig. 4.1).

For all sampling events and both sites, the species with the largest total catch were: western mosquitofish ( $45 \%$ of the total catch), longfin dace (42\%), and Gila topminnow $(11 \%)$ (Appendix S). Individuals of the other five species each made up $<1 \%$ of the total catch. There were substantial differences in the percentage of total catch by species between sites and among sampling events for the three most common species (Fig. 4.2). For both sites, percentage of total catch of western mosquitofish increased throughout the study (Fig. 4.2). In the channel, longfin dace showed a consistent decrease while Gila topminnow remained constant, but in the river the longfin dace and Gila topminnow showed inverse patterns of percent total catch (Fig. 4.2).

The proportion of females to males was high for both the Gila topminnow (3.2 $\pm 0.87 \mathrm{SE})$ and western mosquitofish $(2.1 \pm 0.36 \mathrm{SE})$ from all sites and sampling events (Appendix S). We noted breeding coloration only in the desert sucker (on 4 April 2001).

Table 4.1. Number of fish caught during four sampling periods at Tumacácori NHP, 20012002. See Appendix $B$ for scientific names and Appendix $S$ for number of individuals caught by sampling event.

\begin{tabular}{lrc}
\hline Common name & $\begin{array}{c}\text { Tumacácori } \\
\text { Channel }\end{array}$ & $\begin{array}{c}\text { Santa Cruz } \\
\text { River }\end{array}$ \\
\hline longfin dace & 434 & 979 \\
\hline Sonora sucker & 24 & \\
\hline desert sucker & 6 & \\
\hline western mosquitofish & 1,243 & 273 \\
\hline Gila topminnow & 172 & 182 \\
\hline green sunfish & 1 & 4 \\
\hline bluegill sunfish & 6 & \\
\hline bluegill/green sunfish hybrid & 1 & 1 \\
\hline largemouth bass & 3 & 1,439 \\
\hline Total catch & 1,890 & \\
\hline
\end{tabular}

\section{Inventory Completeness}

Based on distribution records (Minckley 1973) and expert opinion (Andrew Schultz, University of Arizona $\mathrm{PhD}$ candidate), we believe that we documented all species that are thought to occur in the park. It should be noted, however, that additional non-native species may be present (but undetected) or become established in the park.

\section{Gila Chub and Desert Pupfish}

The Gila chub (Gila intermedia) and desert pupfish (Cyprinodon macularius macularius) have not been recorded from the vicinity of the park but may have occurred historically. The U.S. Fish and Wildlife Service lists both species as endangered (AZGF 2004). The Gila chub is only known to occur in a few sites in the Santa Cruz River basin and nowhere near Tumacácori NHP (Weedman et al.1996). The desert pupfish was extirpated from the Santa Cruz River by 1904 (Minckley 1973). 

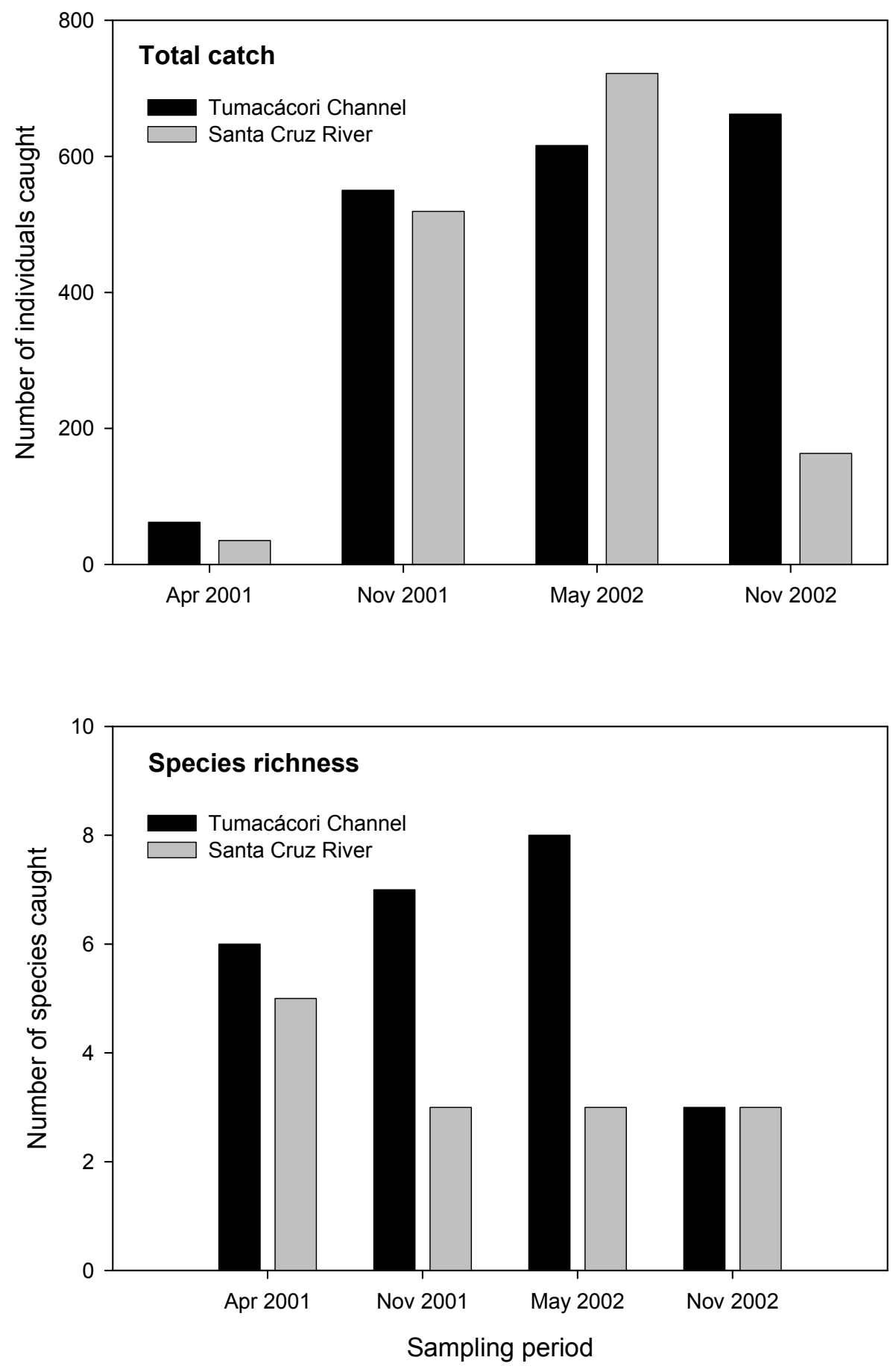

Figure 4.1. Total catch and species richness of fish, by sampling period, Tumacácori NHP, 2001-2002. 

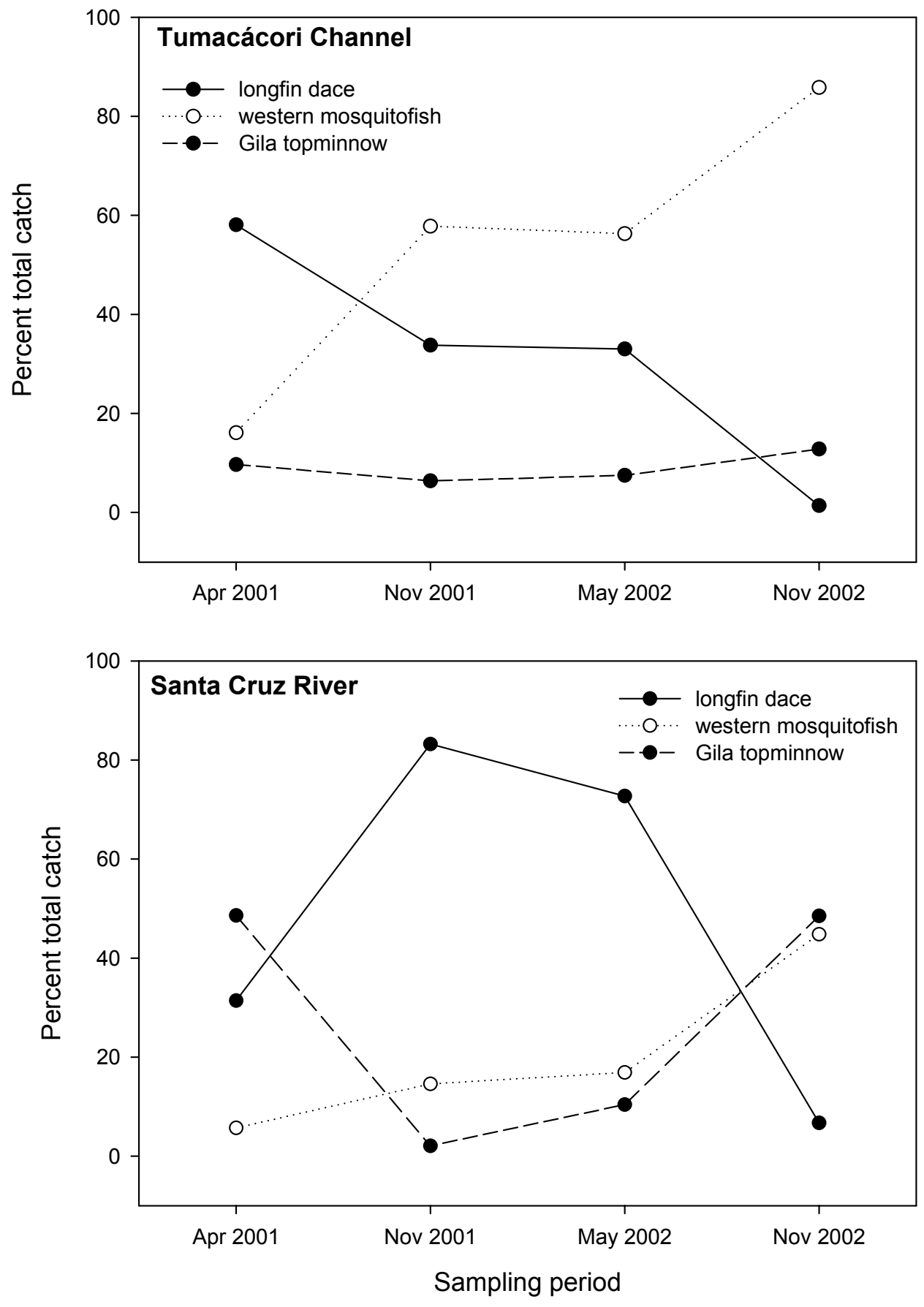

Figure 4.2. Percent total catch, by sampling period, for the three most common species of fishes at both sampling sites, Tumacácori NHP, 2001-2002. 


\section{Discussion}

\section{Gila Topminnow}

The apparent persistence of the federally endangered Gila topminnow in the Tumacácori Channel is perhaps the most important finding of our inventory effort. We found Gila topminnow in all sampling periods (Appendix S) and were likely present in the channel during the extreme drought of the late spring/early summer of 2002 (B. Powell, pers. $o b s$.), during which time no surface water was present in the river site. Therefore, the channel may act as a refugium for the species during these extreme drought events.

The Gila topminnow was once the most abundant species in the southwest, but within the last 20 years has become restricted to approximately 14 isolated populations in the greater Gila River watershed (which includes the Santa Cruz River) (Meffe et al. 1983, Weedman and Young 1987, Weedman 1998, Minckley 1999). As with most native fish declines, that of the Gila topminnow is thought to be the result of habitat destruction due to grazing, groundwater pumping, water diversion, drought, and the introduction of non-native species, especially the western mosquitofish and American bullfrog (Miller 1961, AZGF 1995). Despite the presence of western mosquitofish and American bullfrogs in the channel, Gila topminnows are persisting (Table 4.1). Because our survey effort was not designed to estimate abundance, it is not possible to infer population size or trends in abundance of the Gila topminnow, though the 14-fold increase in number of individuals captured between the first and last sampling event in the channel may suggest a population increase. The high ratio of female to male Gila topminnow is not unusual and is at the low end of the 1.5 to 6.3 females per male ratio reported in the literature (Schoenher 1974; cited in Weedman 1998).

\section{Desert and Sonora Suckers}

The presence of desert and Sonora suckers for the first three sampling events in the Tumacácori Channel is significant because both species are rare in southern Arizona (Recon 2004). There is at least one prior sighting of the desert sucker in the channel in June 1999 (Voeltz and Bettaso 2003).

However, we did not find either species during our fourth sampling period in fall 2002, which was after a period of lower than average rainfall for the region (Fig. 2.4). It is possible, but not likely, that we missed them on the fourth visit. Assuming they were not present, the possible loss of these species from the park is particularly troubling given that it is thought to be sedentary (Bestgen et al. 1987); movement back to the park may take considerable time or may not happen at all. However, it is clear that habitat exists for these species in the channel near where it enters the river. The breeding coloration of a desert sucker in April is consistent with its typical breeding period of spring to early summer (Recon 2004). Both sucker species are designated "Species of Concern" by the U.S. Fish and Wildlife Service (HDMS 2004).

\section{Western Mosquitofish and Other Non-native Fishes}

Once introduced throughout the western U.S. to control mosquito populations, the western mosquitofish is thought to be one of the major reasons for population declines of the Gila topminnow (and other small native fishes in the southwest) through predation, harassment, and competition (Meffe 1985, Courtenay and Meffe 1989). One study indicates that Gila topminnow cannot exist sympatrically with western mosquitofish; within two years of the western mosquitofish introduction into Arivaipa Creek in Arizona, the topminnow disappeared from the creek (Miller 1961). Other studies have shown the local extirpation of the endangered Sonoran topminnow (Poeciliopsis occidentalis) in Arizona after the introduction of western mosquitofish (Meffe et al. 1983, Meffe 1985, Marsh and Minckley 1990). Therefore, the persistence of the Gila topminnow in presence of western mosquitofish is notable.

In addition to large numbers of western mosquitofish, we recorded three other non- 
native sport-fish species: largemouth bass, bluegill, and green sunfish (Table 4.1). Although we recorded these species in low numbers (11 individuals total) and inconsistently (Appendix S), their impact on the native fishes cannot be underestimated; all three species are predatory. These aggressive fishes have impacts on other fauna as well; they have likely contributed to the decline of the Chiricahua leopard frog in southeastern Arizona (Rosen et al. 1995).

Crayfish

During most of our surveys, we observed crayfish (Orconectes virilis; Fig. 4.3), an important non-native invertebrate, especially in the channel. Crayfish are one of the most serious threats to native aquatic biota because they effectively compete with aquatic herbivores, prey on aquatic invertebrates and vertebrates, disrupt normal nutrient cycling, and decrease aquatic macroinvertebrate diversity (Creed 1994, Fernandez and Rosen 1996). Crayfish are extremely drought resistant; they burrow in moist soil during dry periods thereby presenting a persistent threat (Holdich and Lowery 1988, Fernandez and Rosen 1996, Kubly 1997). In addition, their extensive burrowing leads to bank erosion, increased turbidity, and siltation, all of which can restrict reproduction of native fishes requiring coarse gravel for egg development (Fernandez and Rosen, 1996). Fernandez and Rosen (1996) suggest eradication methods that include poisoning heavily populated sites, trapping more lightly populated regions, reintroduction of natural predators such as native river otters, and building barriers to prevent upstream spread.

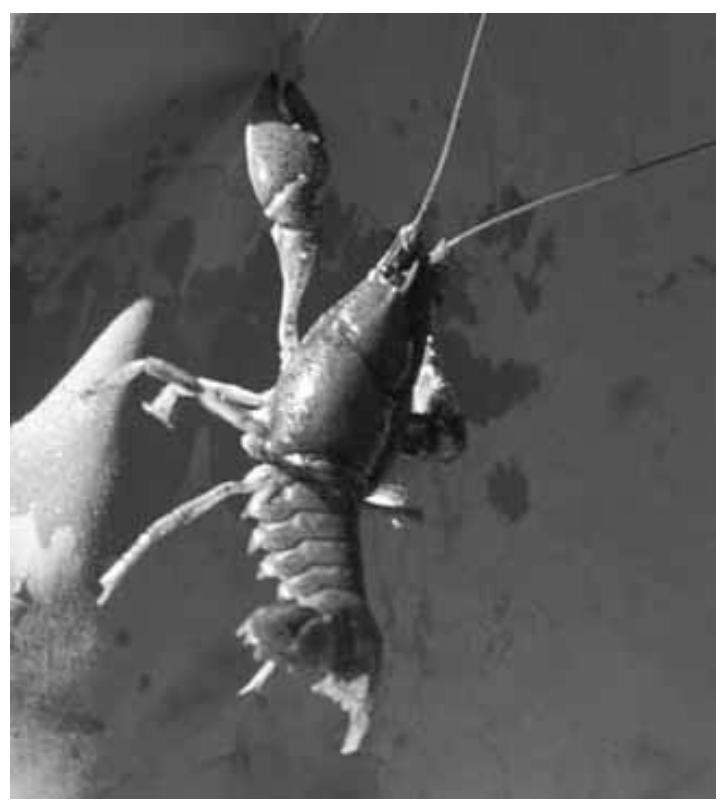

Figure 4.3. Crayfish, Tumacácori NHP, November 2002. 


\section{Chapter 5: Amphibian and Reptile Inventory}

\section{Previous Research}

To our knowledge, there has been no inventory or research related to amphibians and reptiles ("herpetofauna") at Tumacácori NHP, though we located two specimens collected from the park (Appendix O).

\section{Methods}

We surveyed for herpetofauna in 2001 and 2002 using four methods representing plotbased and more flexible non-plot based methods (Table 5.1). The latter approach allowed observers to respond to environmental conditions, such as temperature and precipitation, and adjust search time, intensity, and location accordingly. This flexibility was important for detecting rare, elusive, or ephemeral species most likely missing from existing records. We used both diurnal and nocturnal surveys in an effort to detect species with restricted periods of activity (Ivanyi et al. 2000). Finally, we considered amphibians and reptiles together in this report because we used the same search methods for both groups.

\section{Notes on Species Identifications}

The most challenging reptiles to identify in the region are whiptail lizards (Cnemidophorus species; now referred to as Aspidoscelis by some sources). Many of these parthenogenetic (non-sexually reproducing) whiptail lineage classes may have arisen as hybrids more than once from the same diploid, sexually reproducing parent species (Degenhardt et al. 1996). Therefore, it is possible that several undescribed "parthenospecies" exist in the desert southwest, but these questions have not yet been resolved by experts. Indeed, systematics of the genus Cnemidophorus remains one of the most challenging problems in herpetology (Wright 1993).

At Tumacácori NHP we saw "classic" Sonoran whiptails (adults with six longitudinal dorsal stripes, light spots in dark and occasionally light dorsal areas; dorsal stripes more yellow anteriorly; overall color was brown dorsally and unmarked white-cream ventrally; tail was more brownish-orange than bluish as seen in

Table 5.1. Amphibian and reptile survey effort by method, Tumacácori NHP, 2001-2002.

\begin{tabular}{|c|c|c|c|c|c|c|c|}
\hline \multirow[b]{2}{*}{ Survey type } & \multirow[b]{2}{*}{ Park unit } & \multirow[b]{2}{*}{ Community type ${ }^{a}$} & \multicolumn{2}{|c|}{2001} & \multicolumn{2}{|c|}{2002} & \multirow[b]{2}{*}{$\begin{array}{c}\text { Total survey } \\
\text { hours }\end{array}$} \\
\hline & & & $\begin{array}{c}\text { Survey } \\
\text { units }^{b}\end{array}$ & $\begin{array}{l}\text { Survey } \\
\text { hours }\end{array}$ & $\begin{array}{c}\text { Survey } \\
\text { units }\end{array}$ & Survey hours & \\
\hline \multirow[t]{6}{*}{ Intensive - diurnal } & Calabazas & Semi-desert grassland & 2 & 6.0 & 0 & & 6.0 \\
\hline & Guevavi & Semi-desert grassland & 1 & 3.0 & 0 & & 3.0 \\
\hline & Tumacácori & Agricultural & 2 & 4.0 & 0 & & 4.0 \\
\hline & & Bosque & 3 & 8.0 & 0 & & 8.0 \\
\hline & & Cleared bosque & 1 & 4.0 & 0 & & 4.0 \\
\hline & & Riparian & 6 & 16.0 & 0 & & 16.0 \\
\hline \multirow[t]{3}{*}{ Extensive - diurnal } & Calabazas & all & 0 & & 1 & 3.8 & 3.8 \\
\hline & Guevavi & all & 0 & & 1 & 2.0 & 2.0 \\
\hline & Tumacácori & all & 11 & 31.5 & 9 & 25.3 & 56.7 \\
\hline \multirow[t]{3}{*}{ Extensive - nocturnal } & Calabazas & all & 5 & 8.5 & 1 & 1.0 & 9.5 \\
\hline & Guevavi & all & 5 & 9.0 & 1 & 2.0 & 11.0 \\
\hline & Tumacácori & all & 24 & 69.3 & 6 & 15.5 & 84.8 \\
\hline Pitfall array & Tumacácori & Riparian & 20 & 312.2 & 24 & 359.9 & 672.1 \\
\hline
\end{tabular}

a See text for classification of community types.

${ }^{b}$ Number of plots for intensive surveys, survey routes for extensive surveys, or trapping sessions for pitfall array. 
the Gila spotted whiptail [C. flagellicaudus]; Degenhardt et al. 1996, Phil Rosen pers. obs.) and a variation of this classic appearance (possibly older individuals) that superficially resembled the Gila spotted whiptail. In this document we report all of these individuals as Sonoran whiptails.

\section{Spatial Sampling Design}

For all methods except intensive surveys, we surveyed for herpetofauna in non-random sites because we wanted to detect as many species as possible. To determine locations for intensive survey plots we used a modified simple-random sampling design (Thompson 1992) whereby we used ArcView GIS software to select points $(n=15)$ at random in each park unit to serve as the southwest corner of each plot. We then post-stratified plots (Thompson 1992) by vegetation type; in lieu of a vegetation map for the park we used aerial photographs to estimate vegetation types and moved the location of some plots that appeared to cover more than one vegetation type into the type representing the majority of the area.

\section{Intensive Surveys}

In 2001 we used searches constrained by both time and area to provide a standardized survey method. These surveys are similar to visual encounter surveys (described by Crump and Scott [1994]), but were confined to a 1 ha (100 $\mathrm{x} 100 \mathrm{~m}$ ) plot. Due to the heterogeneity of vegetation types at the Tumacácori unit, our random locations resulted in plots representing each of the dominant community types in the park: riparian, mesquite bosque, semi-desert grassland, and agricultural land (Figs. 5.1, 5.2). Riparian plots included a mixture of sandy, open floodplain and dense riparian vegetation. One of the mesquite bosque plots (referred to as "cleared bosque") was located at the festival grounds where grasses were cut regularly, most perennial vegetation had been cleared, and only scattered large mesquites remained.

\section{Field Methods}

We visited each plot twice in a morning (each time with a different observer) to increase the probability that a survey occurred during a period of peak activity for diurnal lizards, because activity levels vary with temperature (Rosen 2000). We determined UTM coordinates for each of the four plot corners using a Trimble GPS unit and marked the corners with rubber-capped rebar stake (except for the plot located in an agricultural field) (Appendix K). We wrote a brief description of the vegetation and soil characteristics of the area. Before and after each survey we recorded weather information: temperature, $\%$ relative humidity, $\%$ cloud cover, wind speed $[\mathrm{km} / \mathrm{h}]$, and an overall description of the conditions. We used Garmin Emap GPS units to ensure that we stayed within the plot during the search. For each animal that we observed, we recorded species (using a four letter code) and sex and age class (if known).

\section{Effort}

We visited all plots in the spring (24-27 April), and most plots again in the summer (910 September; Table 5.1) of 2001. We began all 35 surveys (one person-hour each) between 7:30 A.M. and 12:30 P.M. In 2002 we chose not to continue intensive surveys because of the relatively low number of species and individuals recorded and instead focused our efforts on other methods.

\section{Analysis}

We estimated relative abundance for each species as the mean number of individuals recorded per person-hour. We estimated species richness by community type using only intensive surveys, but estimated species richness by park unit using data from both intensive and extensive surveys. We combined survey types for richness estimates because summaries of intensive search data are biased toward diurnally active species; we did not complete any nocturnal/crepuscular intensive surveys.

\section{Extensive Surveys}

We designed extensive surveys to enable us to search areas that, based on our field experience, were likely to have high species richness or species not previously recorded. Extensive surveys, a type of visual-encounter 

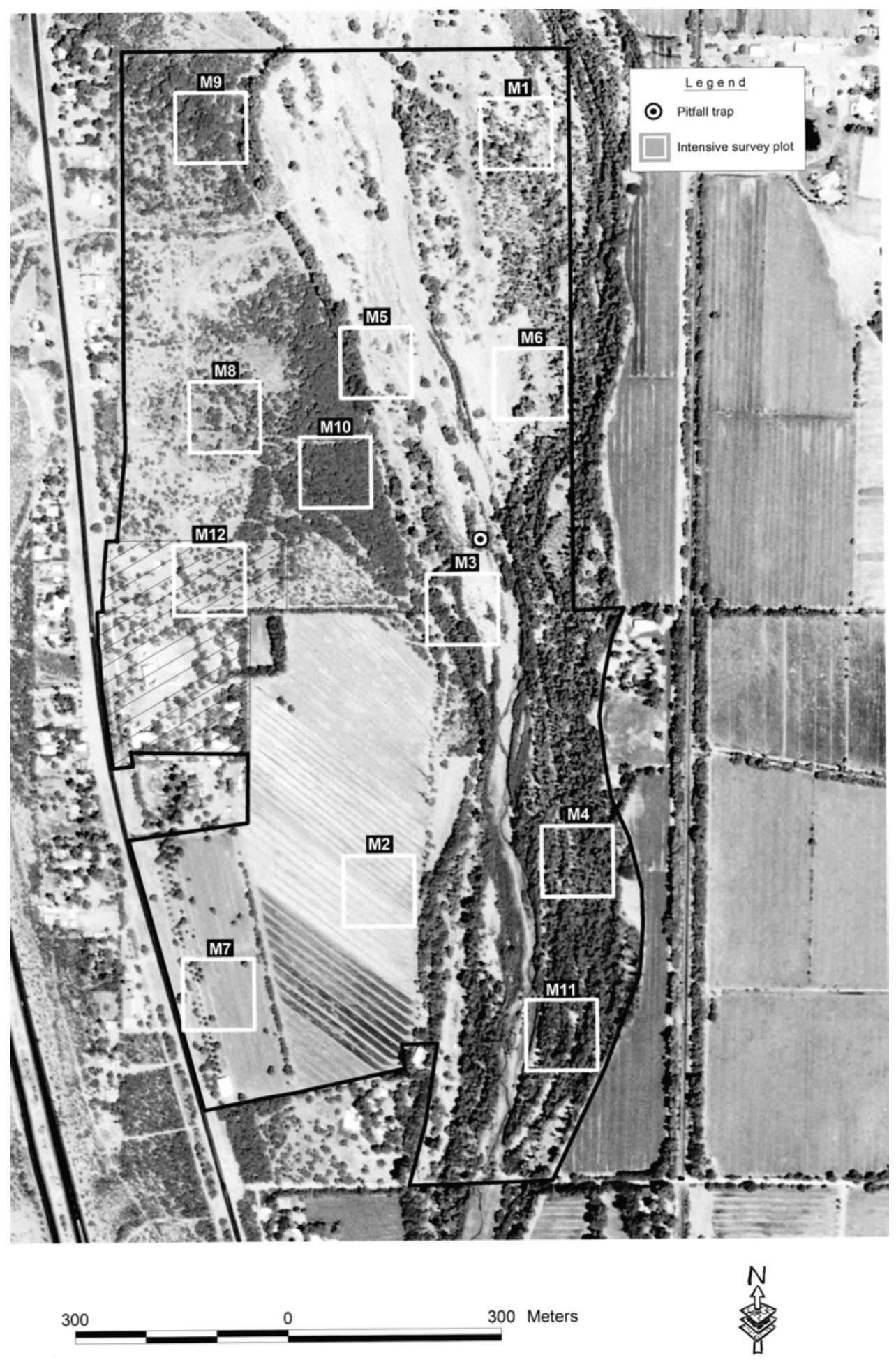

Figure 5.1. Locations of intensive survey plots and pitfall trap array for amphibians and reptiles, Tumacácori unit, Tumacácori NHP, 2001-2002. See Appendix K for UTM coordinates. 

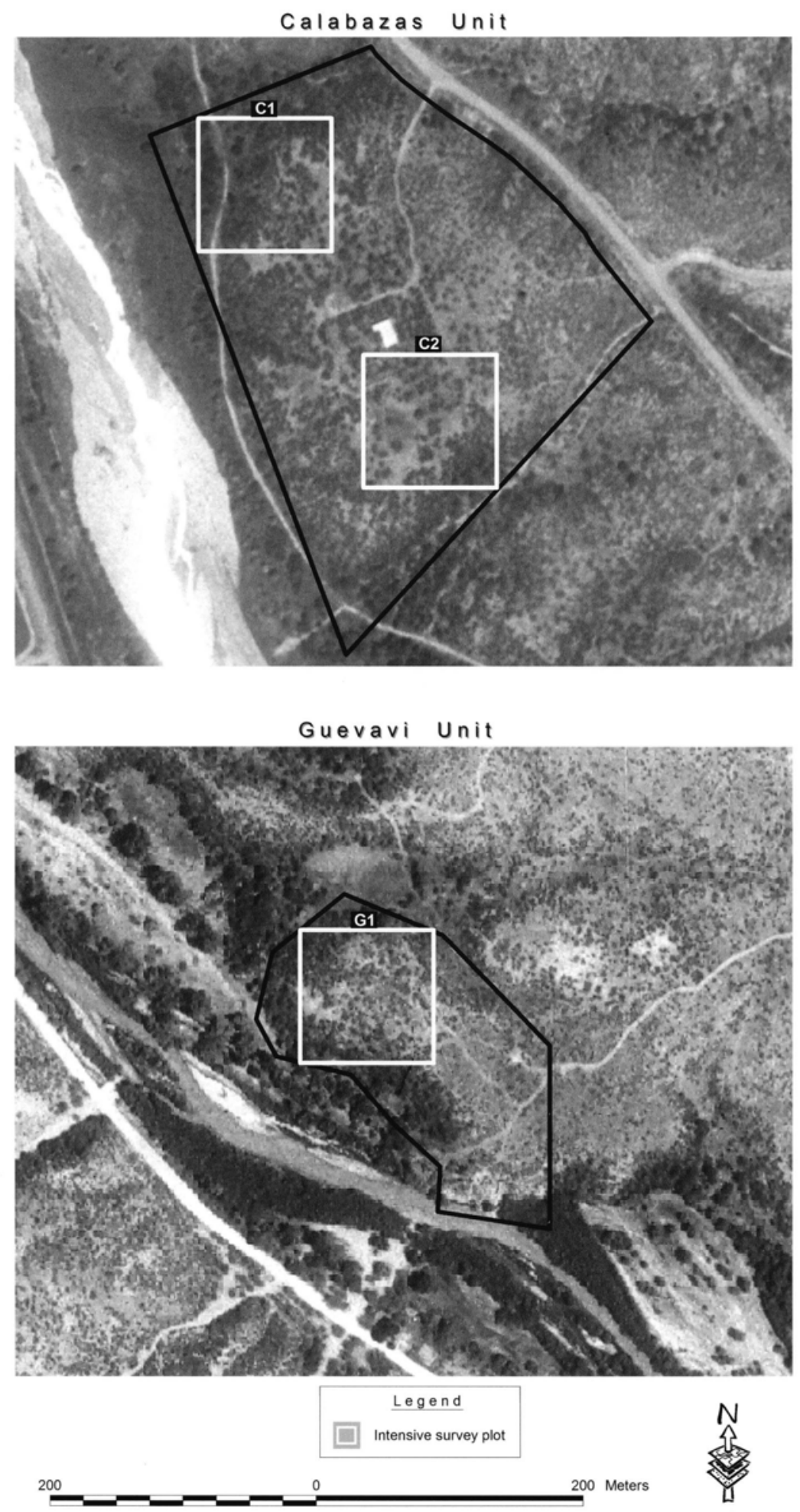

Figure 5.2. Locations of intensive survey plots for amphibians and reptiles, Calabazas and Guevavi units, Tumacácori NHP, 2001-2002. See Appendix K for UTM coordinates. 
survey (Crump and Scott 1994), differed from intensive surveys in that they were not constrained by area or time. In 2002 we used this method almost exclusively because of its efficiency. In general we focused extensive surveys during the cooler morning, evening, and nighttime periods to maximize our chances of encountering snakes and amphibians, which would be active during these times (Ivanyi et al. 2000).

\section{Field Methods}

We used the extensive survey method for both diurnal and nocturnal surveys. Nocturnal surveys were defined as those beginning after 5 P.M. and lasting more than 1.5 hours, often including the crepuscular period. Search times varied from approximately one to five hours (mean $=2.9$ hours) depending on conditions and logistical constraints. To increase the odds of finding rare animals, we placed 20 "cover boards" $(0.5 \times 0.5 \mathrm{~m}$ plywood squares which could be used as cover by animals; Fellers and Drost 1994) around the festival grounds area at the Tumacácori unit, and checked these opportunistically by turning the boards. Before and after each survey we recorded weather information: temperature, $\%$ relative humidity, \% cloud cover, wind speed $[\mathrm{km} / \mathrm{h}]$, and an overall description of the conditions. For each amphibian and reptile observed, we recorded species and sex and age class (if known). We recorded UTM coordinates to define the boundaries of our search area or the path we followed during our surveys.

\section{Effort}

We spent 168 hours on 52 extensive surveys between 24 April and 24 September 2001, and between 11 July and 25 August 2002 (Table 5.1 ). Almost $90 \%$ of the surveys $(n=46)$ were initiated during the cooler evening, nighttime, or morning hours (5 P.M. to 9 A.M.). It is not possible to accurately quantify search effort (total number of person-hours of searching) because more than one observer participated in some searches, and observers were occasionally close enough to one another to influence findings (i.e., an observer may have recorded an animal that was flushed by another observer). Also, volunteer observers sometimes accompanied crewmembers and although they likely increased the number of observations, they were not as skilled at finding animals as crew members.

\section{Analysis}

We primarily used extensive survey data in conjunction with intensive survey data to estimate species richness by park unit, and for the park as a whole. We report the number of individuals recorded per ten hours of search time, regardless of the number of observers.

\section{Pitfall Trap Array}

Pitfall traps, a live-trap, passive sampling technique, are useful in detecting species that may be difficult to observe because of rarity, limited activity periods, or inconspicuous behavior (Corn 1994).

\section{Field Methods}

We constructed the pitfall trap array by placing three 19-L buckets roughly $8 \mathrm{~m}$ away and at angles of approximately 120 degrees each from a central bucket (Gibbons and Semlitsch 1981). We dug shallow trenches between buckets in which we placed drift fences (7.6-m long, $0.5-\mathrm{m}$ tall aluminum-flashing that was supported with rebar) that connected each of the three outside buckets to the central bucket. Buckets were buried so that the lip of the bucket was at ground level. We placed cover boards (50 x $50 \mathrm{~cm}$ pieces of plywood) over the buckets to: (1) keep the animals cool during the day, (2) minimize mortality, and (3) attract additional animals (Corn 1994).

\section{Effort}

We established one pitfall trap array (with four pitfall traps and six funnel traps) in the expansion area adjacent to Tumacácori NHP, near the bank of the Santa Cruz River (Fig. 5.1). We operated the pitfall trap array for a total of 672 hours between 11 July and 24 September 2001, and between 10 July and 26 September 2002 (Table 5.1).

\section{Analysis}

We report the number of animals captured per 100 hours of array operation. Results 
primarily contributed to species lists for the park.

\section{Incidental Observations}

When we encountered uncommon amphibians and reptiles outside of formal surveys, we recorded the species, sex and age class (if known), time of observation, UTM coordinates, and route we were following. Incidental detections recorded by other survey crews (e.g., bird crew) were not accompanied by route descriptions. We collected incidental observations between 25 April and 24

September 2001, and between 15 May and 25 August 2002.

\section{Results}

We recorded seven amphibian and 17 reptile species at Tumacácori NHP in 2001 and 2002 (Tables 5.2-5.4, Appendix C). We recorded the most species $(n=22)$ at the Tumacácori unit and the fewest $(n=9)$ at the Guevavi unit (Tables 5.2, 5.3; Appendix C). A single Woodhouse's toad was heard calling on 24 July 2001; otherwise the only amphibians heard vocalizing were American bullfrogs.
We spent 208 hours actively searching for amphibians and reptiles at the park (103 hours on diurnal surveys, 105 hours on nocturnal surveys), and 672 hours sampling passively via the pitfall array (Table 5.1). Cumulative active search time at the Tumacácori unit (173.5 hours) was far greater than at the Calabazas (19.3 hours) or Guevavi units (16 hours).

\section{Intensive Surveys}

We recorded the most species $(n=7)$ in the semi-desert grassland community type and the fewest $(n=2)$ in the mesquite bosque community type (Table 5.2). Although Clark's spiny lizard was the most widespread species (recorded at least once in all park units and community types), the Sonoran spotted whiptail was the most abundant reptile on plots in all community types, except in the mesquite bosque where it was not recorded. The common lesser earless lizard, Clark's spiny lizard, and regal horned lizard were most abundant in the semi-desert grassland community type; the eastern fence

Table 5.2. Relative abundance of reptiles ${ }^{a}$ recorded during intensive surveys, by community type and park unit, Tumacácori NHP, 2001-2002. See Appendix C for scientific names.

\begin{tabular}{|c|c|c|c|c|c|c|c|c|c|c|c|c|c|}
\hline \multirow[b]{3}{*}{ Common name } & \multirow[b]{3}{*}{$n$} & \multirow{2}{*}{\multicolumn{2}{|c|}{$\begin{array}{l}\text { Calabazas } \\
\text { Semi-desert } \\
\text { grassland }\end{array}$}} & \multirow{2}{*}{\multicolumn{2}{|c|}{$\begin{array}{c}\text { Guevavi } \\
\text { Semi-desert } \\
\text { grassland } \\
\end{array}$}} & \multicolumn{8}{|c|}{ Tumacácori } \\
\hline & & & & & & \multicolumn{2}{|c|}{ Agricultural } & \multicolumn{2}{|c|}{$\begin{array}{c}\text { Mesquite } \\
\text { bosque }\end{array}$} & \multicolumn{2}{|c|}{$\begin{array}{c}\text { Cleared } \\
\text { bosque }\end{array}$} & \multicolumn{2}{|c|}{ Riparian } \\
\hline & & Mean & SE & Mean & SE & Mean & SE & Mean & SE & Mean & SE & Mean & SE \\
\hline common lesser earless lizard & 4 & & & 0.7 & 0.67 & & & & & & & 0.1 & 0.09 \\
\hline Clark's spiny lizard & 15 & 0.2 & 0.17 & 0.7 & 0.67 & 0.3 & 0.25 & 0.4 & 0.26 & 0.3 & 0.25 & 0.4 & 0.22 \\
\hline eastern fence lizard & 2 & & & & & & & & & & & 0.1 & 0.09 \\
\hline ornate tree lizard & 20 & 1.5 & 0.67 & 0.7 & 0.33 & 0.3 & 0.25 & & & 3.0 & 1.29 & 2.1 & 0.62 \\
\hline regal horned lizard & 1 & 0.2 & 0.17 & & & & & & & & & & \\
\hline desert grassland whiptail & 42 & 0.2 & 0.17 & & & 0.8 & 0.48 & 0.1 & 0.13 & 0.5 & 0.29 & 2.2 & 0.78 \\
\hline Sonoran spotted whiptail & 125 & 2.5 & 0.92 & 1.0 & 1.00 & 1.0 & 0.71 & & & 3.3 & 1.93 & 5.6 & 1.64 \\
\hline gopher snake & 2 & 0.2 & 0.17 & & & & & & & 0.3 & 0.25 & & \\
\hline unknown lizard & 58 & 0.2 & 0.17 & 0.3 & 0.33 & 0.3 & 0.25 & & & 0.5 & 0.50 & 0.9 & 0.28 \\
\hline Species richness & 8 & 6 & & 4 & & & & 2 & & & & & \\
\hline Total no. detections & & 2 & & 10 & & & & 4 & & & & & \\
\hline
\end{tabular}

a No amphibians were recorded during these surveys. 
Table 5.3. Number of amphibians and reptiles recorded per 10 hours of extensive surveys, and number of incidental observations for additional species, by park unit, Tumacácori NHP, 2001-2002. See Appendix C for scientific names.

\begin{tabular}{|c|c|c|c|c|c|c|c|}
\hline \multirow{2}{*}{$\begin{array}{l}\text { Group } \\
\text { Common name }\end{array}$} & \multirow{2}{*}{$\begin{array}{c}\text { Total } \\
\text { number } \\
\text { recorded }\end{array}$} & \multicolumn{3}{|c|}{$\begin{array}{c}\text { Number of individuals recorded per } 10 \\
\text { hours of survey }\end{array}$} & \multicolumn{3}{|c|}{ Incidental observations } \\
\hline & & Calabazas & Guevavi & Tumacácori & Calabazas & Guevavi & Tumacácori \\
\hline \multicolumn{8}{|l|}{ Amphibians } \\
\hline Couch's spadefoot & 115 & 1.5 & 10.8 & 7.0 & & & \\
\hline Mexican spadefoot & 3 & & 0.8 & 0.1 & 1 & & \\
\hline Colorado River toad & 2 & & & 0.1 & & & \\
\hline Woodhouse's toad & 10 & & & 0.7 & & & \\
\hline American bullfrog & 41 & & & 2.9 & & & \\
\hline Great Plains toad & 17 & & & 1.2 & & & \\
\hline unknown Bufo species ${ }^{a}$ & 37 & & & 2.6 & & & \\
\hline \multicolumn{8}{|l|}{ Reptiles } \\
\hline Sonora mud turtle & 5 & & & 0.4 & & & \\
\hline western box turtle & 1 & & & & 1 & & 1 \\
\hline common lesser earless lizard & 9 & & 0.8 & 0.6 & 1 & & \\
\hline Clark's spiny lizard & 25 & 1.5 & 0.8 & 1.6 & & & \\
\hline eastern fence lizard & 18 & & & 1.3 & & & \\
\hline ornate tree lizard & 55 & 3.0 & & 3.6 & & & \\
\hline regal horned lizard & 1 & & & $<0.1$ & & & \\
\hline desert grassland whiptail & 70 & & & 4.9 & & & \\
\hline Sonoran spotted whiptail & 242 & 3.8 & 9.2 & 1.6 & & & \\
\hline coachwhip & 2 & & & 0.1 & & & \\
\hline western patch-nosed snake & 1 & 0.8 & & & & 1 & \\
\hline long-nosed snake & 2 & $0.8^{b}$ & & $<0.1^{b}$ & & & \\
\hline Southwestern black-headed snake & 2 & & & 0.1 & & & \\
\hline night snake & 2 & & & 0.1 & & 1 & \\
\hline Sonoran coralsnake & 1 & & $0.8^{b}$ & & & & \\
\hline western diamond-backed rattlesnake & 10 & $1.5^{b}$ & 2.3 & 0.4 & & & \\
\hline Species richness & 23 & 7 & 7 & 20 & 3 & 2 & 1 \\
\hline
\end{tabular}

a These were juvenile Woodhouse's and Great Plains toads, which are difficult to differentiate.

b Species was only recorded during nocturnal surveys.

lizard and the two whiptails were most abundant in riparian areas; and the ornate tree lizard and gophersnake were most abundant in the cleared mesquite bosque area. We recorded no amphibians during intensive surveys.

We anticipated that surveys in riparian areas would yield more species than surveys in other community types. However, results were mixed. Relative abundance of all reptiles in the riparian community type was $>30 \%$ higher than in any other community type, yet species richness in riparian community type $(n=6$ species) was equal to that of semi-desert grassland community type at the Calabazas unit and only slightly greater than richness in the cleared mesquite bosque community type ( $n=5$ species), where we expended far less survey effort. The eastern fence lizard was the only species that we found only in one community type (riparian) at the Tumacácori unit. Similarly, we recorded the regal horned lizard only in the semi-desert grassland community type in the Calabasas unit.

\section{Extensive Surveys}

We recorded 21 species during extensive surveys, ten of these were not recorded during intensive surveys and seven were not recorded during either intensive surveys or incidental observations (Table 5.3). During nocturnal 
extensive surveys we recorded three reptile species that we did not record during diurnal surveys (intensive or extensive; Tables 5.2, 5.3). Nocturnal surveys were essential for recording amphibian species; of the seven species we recorded, all except one (Great Plains narrow-mouthed toad, captured in the pitfall array) were recorded on nocturnal extensive surveys, whereas only one species (American bullfrog) was recorded during diurnal surveys (all methods combined; Tables 5.2-5.4).

\section{Incidental Observations and Pitfall Array}

We added one new species to the park list by using both incidental observations (western box turtle; Tables 5.3) and the pitfall array (Great Plains narrow-mouthed toad; Table 5.4). Great Plains narrow-mouthed toads may be more common than indicated by our results due to its climbing ability (and thus its potential to escape from pitfall buckets; Corn 1994).

\section{Inventory Completeness}

Species accumulation curves for intensive and extensive surveys show the number of new species reaching their asymptotes (Fig. 5.3), indicating that we recorded most of the species likely to be observed with these methods, at least under the environmental conditions (e.g., lack of precipitation) during our study. A list comparing recorded amphibian species (Appendix C) with possible species (Appendix $G$ ) indicates that we recorded all but three amphibian species that may be present at Tumacácori NHP: canyon tree frog, redspotted toad, and Sonoran green toad. The canyon tree frog was reported from the Santa Cruz River between Tumacácori and Calabazas units by Drost (1998), and was collected near the Santa Cruz River in 1978 (reported by Rosen et al. [2004]); the likely collection site was Potrero Cienega (Phil Rosen, pers. comm.). Eight red-spotted toads were collected between Nogales and Tubac on the Santa Cruz River from 1930 to 1991 (Rosen et al. 2004). The toad was recently reported from roughly $80 \mathrm{~km}$ downstream from the Tumacácori unit on the West Branch (Rosen and Mauz 2001). The Sonoran green toad was collected in the vicinity of the San Xavier Mission on the Santa Cruz River (Sullivan et al. 1996; $60 \mathrm{~km}$ downstream from the Tumacácori unit), and has been recorded by other reliable observers (Phil Rosen, pers. comm.). The few records of the canyon tree frog in the Tumacácori NHP area of the Santa Cruz River suggest that the species may not regularly occur in this area, and to our knowledge the red-spotted toad has not been reported in this area within the last ten years.

Table 5.4. Number of animals captured per 100 hours of pitfall trap operation, Tumacácori unit, Tumacácori NHP, 2001-2002. See Appendix C for scientific names.

\begin{tabular}{|c|c|c|c|c|}
\hline Taxon group & Common name & $\begin{array}{c}\text { Total } \\
\text { number } \\
\text { captured }\end{array}$ & 2001 & 2002 \\
\hline \multirow[t]{4}{*}{ Amphibian } & Couch's spadefoot & 11 & 2.9 & 0.6 \\
\hline & Woodhouse's toad & 2 & 0.6 & \\
\hline & Great Plains narrow-mouthed toad & 1 & 0.3 & \\
\hline & Great Plains toada & 11 & 3.5 & \\
\hline \multirow[t]{4}{*}{ Reptile } & Clark's spiny lizard ${ }^{a}$ & 1 & 0.3 & \\
\hline & eastern fence lizarda & 1 & 0.3 & \\
\hline & desert grassland whiptaila & 5 & 0.6 & 0.8 \\
\hline & Sonoran spotted whiptail & 1 & 0.3 & \\
\hline Mammal & small mammal & 57 & 11.2 & 6.1 \\
\hline
\end{tabular}



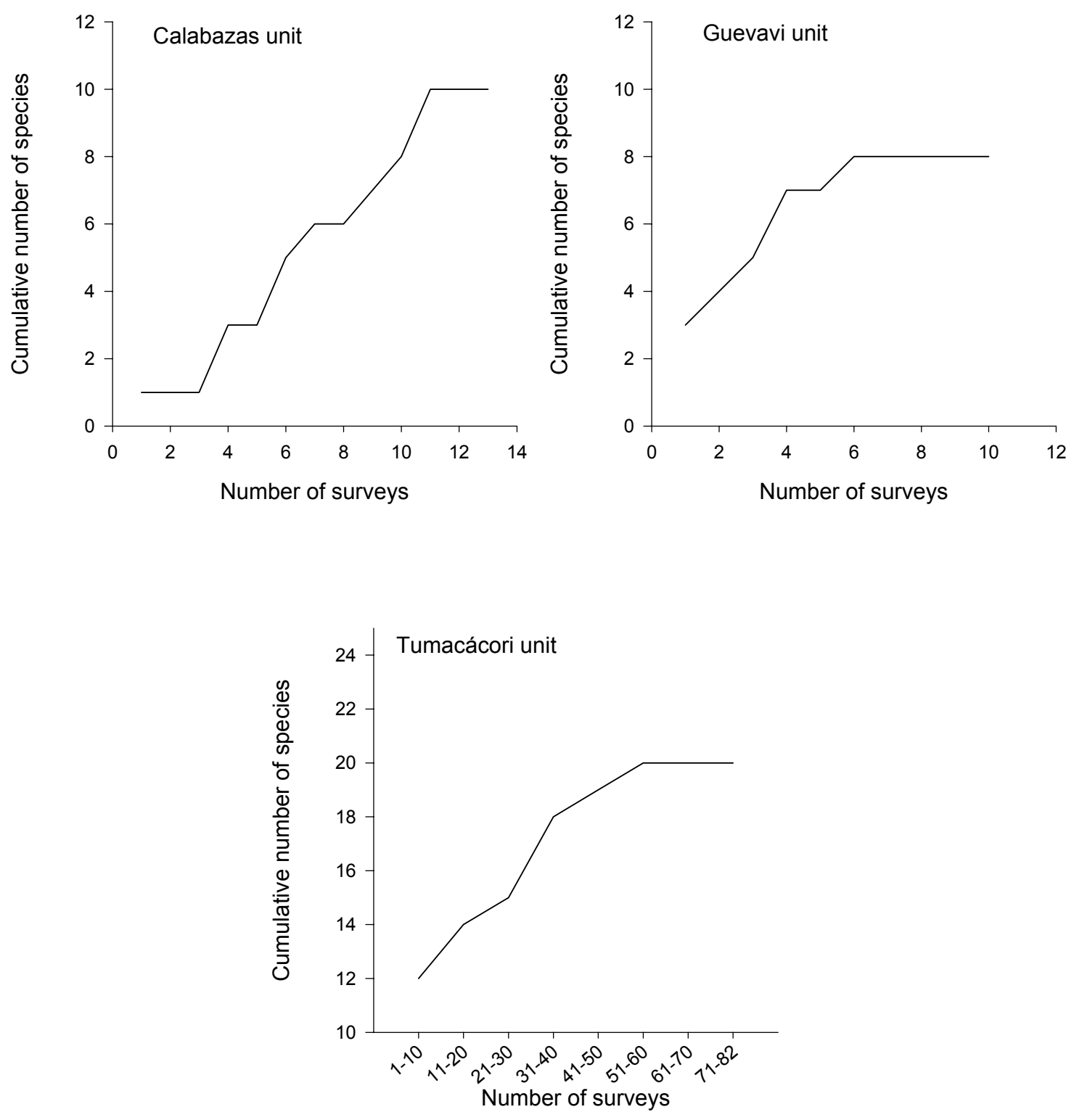

Figure 5.3. Species accumulation curves for intensive and extensive amphibian and reptile surveys, Tumacácori NHP, 2001-2002. 
The published geographic range of two nonnative species may include the park (Stebbins 2003) but to our knowledge they have not yet been recorded in the area. The African clawed frog, which requires permanent water, likely would have been recorded during our surveys in 2002 because drought reduced the amount of surface water to an area that was thoroughly searched. The tiger salamander, which is large, conspicuously colored, and most active during the during monsoon period, was also not detected.

We did not find three frog species that have likely been extirpated from the area: lowland and Chiricahua leopard frogs and the Tarahumara frog. The lowland leopard frog is sufficiently rare to be considered as a candidate for protection under the Endangered Species Act (HDMS 2004) and is unlikely in the area due to habitat degradation and regional population decline. The Chiricahua leopard frog, a species listed as threatened under the Endangered Species Act (HDMS 2004), is also unlikely in the area due to habitat degradation and regional population decline. Finally, the Tarahumara frog, a species that is thought to have been extirpated from the area, may be re-introduced (Stebbins 2003).

In contrast to our amphibian species list, our reptile list for the park is likely far from complete. Reliable reports of the ring-necked snake from the Tumacácori unit (Dennis Jex, pers. comm.) and on Pendleton Drive between Calabazas and Guevavi units (Kevin Bonine, pers. comm.), and three reports of common kingsnakes at the Tumacácori unit in 2002 alone (by the park maintenance crew) indicate these species are present. Drost (1998) reported both black-necked and checkered garter snakes (one individual of each species) between the Tumacácori and Calabazas units. Based on consideration of range maps, known habitat requirements, historic records, and results of a nearby study, an additional 32 species may be present, may have been historically present in the park, or might pass through the park in the course of movement from nearby areas (Appendix G). Of these species, at least the Mexican garter snake is likely extirpated from the area, and several other species are unlikely (but possible) at Tumacácori NHP based on local range and habitat association: yellow mud turtle, zebratailed lizard, desert spiny lizard, mountain skink, tiger whiptail, and saddled and spotted leaf-nosed snakes (Phil Rosen pers. comm.). The Baja California spiny-tailed iguana seems highly unlikely to occur naturally at Tumacácori NHP, but is listed here because Rosen et al. (2004) found a museum specimen that was collected from the area in 1890 (specimen number 17178, Smithsonian National Museum of Natural History). Two non-native turtles, slider (Pseudemys scripta) and spiny softshell (Trionyx spiniferus) have not, to our knowledge, been reported on the Santa Cruz River; however they could be illegally released in the area at any time and they could thus be observed at the park as they have at several other areas in southeast Arizona (Phil Rosen, pers. comm.).

Many of the additional species that may occur at the park are uncommonly seen (e.g., fossorial species that are active on the soil surface for only a small percentage of their lifetimes [Ivanyi et al. 2000]) and some may be extirpated. Therefore, finding additional species at Tumacácori NHP will be a product of many factors: additional time in the field under favorable conditions (e.g., following years with average or above-average precipitation), skilled observers, or simple luck. Although the Santa Cruz River area may provide future source populations for reestablishing additional species at the park, potentially toxic chemicals in the water downstream of the Nogales International Wastewater Treatment Plant may prevent such distribution in the short term (see Water Quality section in Chapter 2).

\section{Discussion}

Tumacácori NHP has potentially high species richness for amphibians and reptiles because of its variety of community types and location along a borderlands riparian area (Felger and 
Wilson 1995). However, dense vegetation in the riparian area and lack of surfaced roads make the park a challenging place to find these animals. Of the 24 species of amphibians and reptiles that we recorded, to our knowledge only two had previously been recorded (as vouchers) for this location (Appendix O). Overall, the species that we recorded in all park units indicate an area that, although far from pristine, maintains moderate species richness both in the presence of human activity (Tumacácori unit) and in relative isolation from human activity (Calabazas and Guevavi units).

We recorded several species at the Tumacácori unit that are associated with riparian areas, such as the eastern fence lizard, Clark's spiny lizard, Woodhouse's toad, American bullfrog, box turtle, Sonoran mud turtle and Great Plains narrow-mouthed toad (Rosen and Mauz 2001, Stebbins 2003). Species richness in the riparian area was somewhat low, however, compared with historical records (e.g., Arnold 1940). We did not find many species associated with water and riparian vegetation (e.g., native frogs and garter snakes; Stebbins 2003). Two species of garter snakes have been recorded on the Santa Cruz River upstream of Tumacácori unit (Drost 1998, see Appendix G), and these species may have been missed by our survey crews or may colonize the Tumacácori unit in the future.

Although we expected that species richness in the riparian area would be higher than other areas, the number of amphibian and reptile species that we recorded during intensive surveys in riparian areas $(n=6)$ was equal to that recorded in semidesert grasslands at Calabazas unit and similar to cleared mesquite bosque ( $n=5$; Table 5.2). This similarity may have been caused by thick vegetation in the riparian area (compared to other community types) that may reduce detectability of animals (Southwell 1996).

A nearby area (about $80 \mathrm{~km}$ north of the Tumacácori unit) that has been the subject of recent research is the West Branch, a tributary of the Santa Cruz River (Rosen and Mauz
2001). Although the authors did not quantify survey effort or size of their study area, the geographic proximity and superficial ecological similarity of the location to Tumacácori NHP make it appropriate to compare the two areas. For that study, Rosen surveyed for amphibians and reptiles in an area within $2 \mathrm{~km}$ of the Santa Cruz River in 2001 (Rosen and Mauz, 2001), and later augmented that research with further surveys, which documented additional species (Phil Rosen, pers. comm.). In total, they recorded the same number of native amphibians species $(n=6)$ (but no American bullfrog) and nearly as many reptile species (15 compared with our 17 species) (Rosen and Mauz 2001, Rosen pers. comm.) as did our effort. While the proportion of lizards to snakes was higher in their study and they recorded several species that we did not (Appendix G), overall species richness was similar between the two areas. Despite the moderately high species richness values for the West Branch area and Tumacácori NHP, both areas host fragments of the herpetofauna community that existed in the area prior to European settlement (Arnold 1940, Rosen and Mauz 2001).

The small Calabazas and Guevavi units appear to possess moderately species-rich herpetofaunas, and the number of species recorded at each unit is notable given our limited search time. A few of these species (western box turtle, western patch-nosed snake, western diamond-backed rattlesnake) have not been recorded by Rosen at his study site on the West Branch (Rosen and Mauz 2001, Phil Rosen pers. comm.), but were historically present in that area (Arnold 1940), suggesting that they may be sensitive to anthropogenic disturbance. Persistence of these species at the Calabazas and Guevavi units suggests that continuing to limit development (and possibly visitation) in these areas may ensure their presence. Recent surveys by other researchers suggest that western box turtle populations may be declining in the area of Tumacácori NHP (particularly in the region of the Calabazas and Guevavi units), possibly due to increased residential development and associated vehicle 
traffic (David Hall, unpub. data). Although the number of detections was low, the occurrence of this species at two park units underscores the importance of these undeveloped park areas. Sonoran coralsnake was the highlight of our findings at the Guevavi unit; this species is listed as Amenazada (federal status similar to Endangered Species Act "Threatened" listing) in Mexico (HDMS 2004).

We recorded American bullfrogs (Fig. 5.4) in the Tumacácori Channel during both herpetological and fish surveys. The American bullfrog is native to eastern North America but has been introduced throughout the western U.S. for food production and sport (Stebbins 2003). The American bullfrog is a species of management concern at Tumacácori NHP because both adults and tadpoles are voracious predators (Kiesecker and Blaustein 1997) and are thought to be partially responsible for the decline of many native fish species (Minckley and Deacon 1991), reptiles (Schwalbe and Rosen 1988), and amphibians (particularly other Ranid frogs; Hayes and Jennings 1986, Lawler et al. 1999) in the southwest.

\section{Notes on Venomous Reptiles}

It should be noted that although we recorded two species of poisonous snake at Tumacácori NHP, the total of ten western diamond-backed rattlesnake observations (likely including multiple records of the same individuals) and one Sonoran coralsnake were the result of over 200 hours of searching by trained herpetologists; these snakes are sufficiently rare to pose a limited threat to visitors. The chances of an accidental encounter resulting in injury are likely small. Furthermore, the majority of reptile bites, reported to Tucson's Arizona Poison and Drug Information Center, were provoked by the victim (e.g., harassment or attempt to handle; APDIC 2003). Even if a bite occurs, chances of death following a reptile bite are less than one percent (APDIC 2003), and no human fatalities have been attributed to the seldom-seen Sonoran coralsnake (Degenhardt et al.1996).

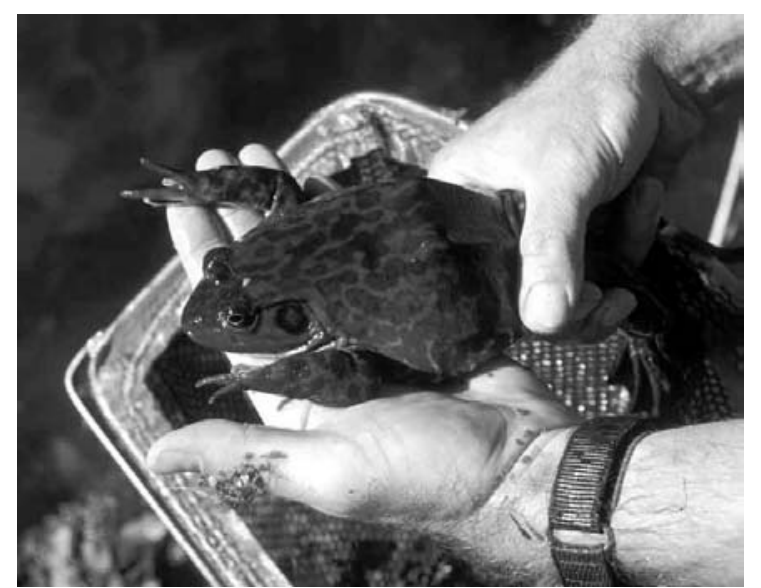

Figure 5.4. American bullfrog, Tumacácori NHP. 


\section{Chapter 6: Bird Inventory}

\section{Previous Research}

Previous bird research at Tumacácori NHP focused on the yellow-billed cuckoo (Powell 2000) and on mist-netting passerines and hummingbirds from 1997 to 2004 (MAPS; Turner 2003, Susan Wethington, unpub. data).

\section{Methods}

We surveyed for birds at the Tumacácori unit in 2001 and at all three units in 2002 and 2003. We used four field methods: variable circularplot (VCP) counts for diurnal breeding-season birds, nocturnal surveys for owls and nightjars during the breeding season, line-transects for fall and winter-season birds, and incidental observations for all birds in all seasons.

Although surveys in the fall and winter were not included in the original study proposal (Davis and Halvorson 2000), we nevertheless felt they were important because many species that use the area during the fall and winter may not be present during VCP surveys. We did, however, concentrate most of our survey effort during the breeding season because bird distribution is relatively uniform during the breeding season due to territoriality among birds (Bibby et al. 2000). This survey timing increases our precision in estimating relative abundance and enabled us to document breeding activity. Our survey period included peak spring migration times for most species, which added many migratory species to our list.

We also sampled vegetation around VCP survey stations. Vegetation structure and plant species composition are important predictors of bird species richness or the presence of particular species (MacArthur and MacArthur 1961, Rice et al. 1984, Strong and Bock 1990, Powell and Steidl 2000). By identifying broad-scale vegetation characteristics associated with high species richness at the park, park managers can guide development and other human impacts away from the areas that contribute disproportionably to the rich bird community.
In most cases we do not report observations that failed to determine the species (e.g., "unknown woodpeckers"). Ravens and meadowlarks are an exception. Both the Chihuahuan and common ravens occur at the park and both species are difficult to differentiate unless they are viewed at a short range under certain conditions or if they are seen flying together (Bednarz and Raitt 2002). We were not able to positively determine the species for any raven sighting and therefore report all observations as "unknown raven." For meadowlarks we were unable to determine the species of one individual observed during line-transect surveys; we report this record as "unknown meadowlark."

\section{Spatial Sampling Designs}

We subjectively determined the location of all survey stations and transect sections as a matter of convenience or logistical necessity. Because of the small size of all three units we almost completely covered the park (Figs. 6.1, 6.2). We did not visit the Calabazas or Guevavi units in 2001 because these units were not included in the original study plan (Davis and Halvorson 2000); however, we included these units in 2002 and 2003 in order to obtain a complete inventory.

We placed VCP stations and line-transect sections in sites selected to represent the bird communities in each park unit (Table 6.1). The relatively low number of stations and sections at Calabazas and Guevavi units are due to their small size. Although each of these smaller units possesses fewer than half the stations or transects present at the Tumacácori unit, together they comprise the most-sampled community type (semi-desert grassland; see below for description of community type designations). The "developed" community type at the Tumacácori unit was represented by only one station or transect section, and this was proportionate to its small area that includes buildings, bird feeders, and ornamental vegetation. 

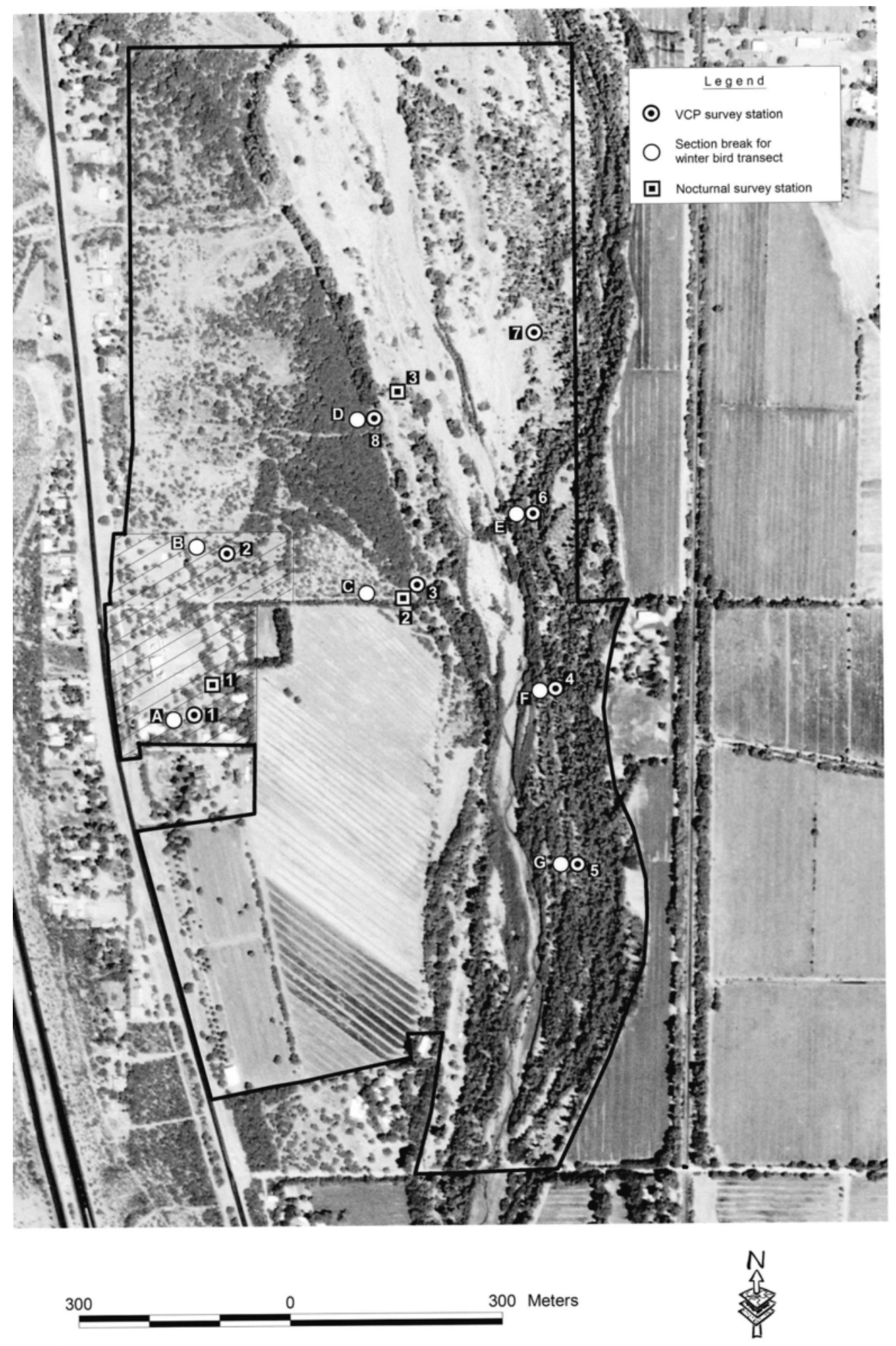

Figure 6.1. Locations of VCP survey stations and line-transect breaks (winter) for birds, Tumacácori unit, Tumacácori NHP, 2001-2003. See Appendix L for UTM coordinates. 

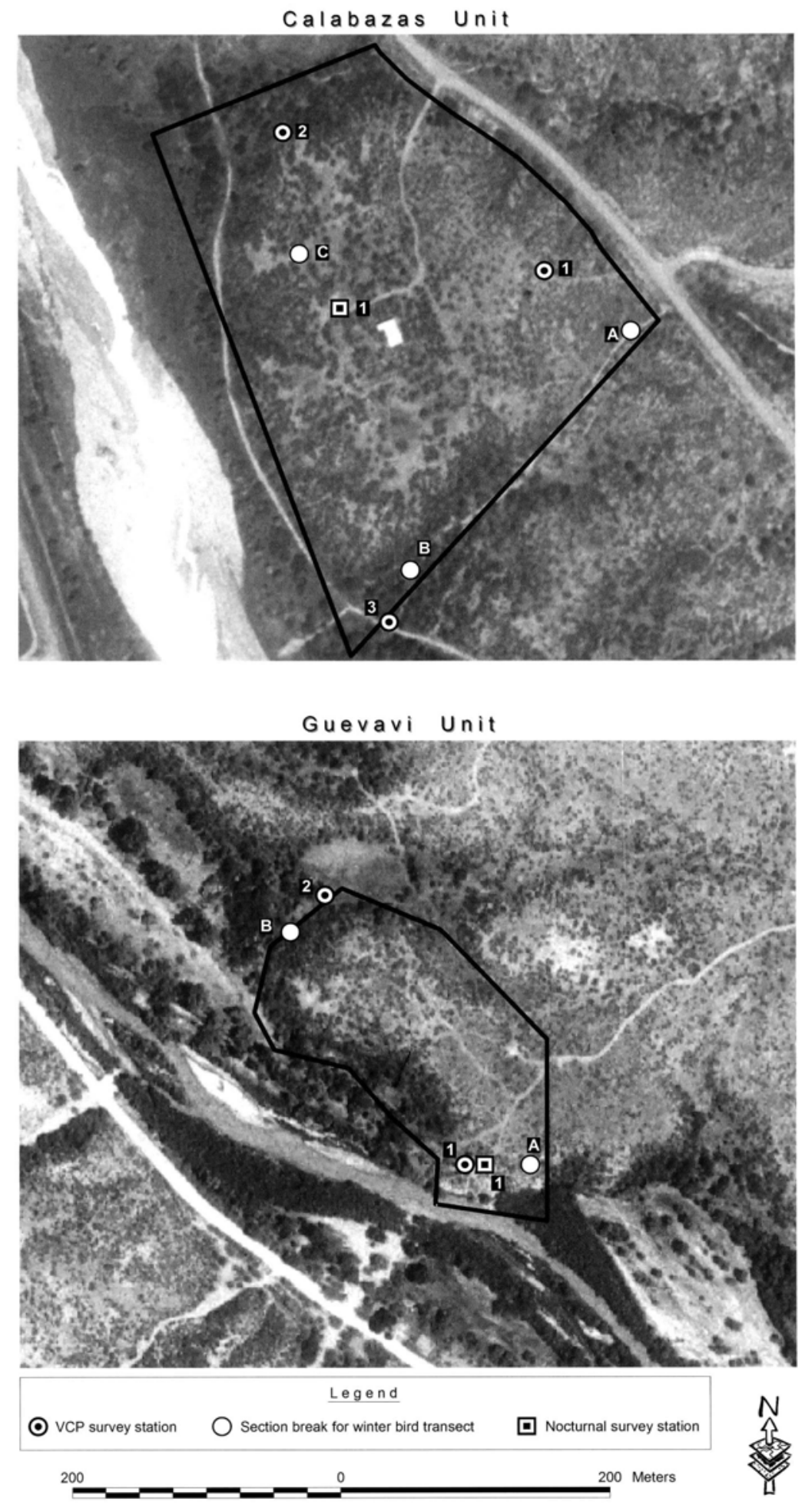

Figure 6.2. Locations of VCP survey stations and line-transect breaks (winter) for birds, Calabazas and Guevavi units, Tumacácori NHP, 2002-2003. See Appendix L for UTM coordinates. 
Table 6.1. Bird survey effort by method and community type, Tumacácori NHP, 2001-2003.

\begin{tabular}{|c|c|c|c|c|c|c|}
\hline \multirow[b]{2}{*}{ Survey type } & \multirow[b]{2}{*}{ Park unit } & \multirow[b]{2}{*}{ Community type } & \multirow{2}{*}{$\begin{array}{l}\text { Number of stations or } \\
\text { sections }\end{array}$} & \multicolumn{2}{|c|}{ Number of visits } & \multirow[b]{2}{*}{ Efforta } \\
\hline & & & & 2001 & $2002 / 2003$ & \\
\hline \multirow[t]{5}{*}{$\mathrm{VCP}$} & Calabazas & Semi-desert grassland & 3 & 0 & 5 & 15 \\
\hline & Guevavi & Semi-desert grassland & 2 & 0 & 5 & 10 \\
\hline & Tumacácori & Mesquite bosque & 3 & $4-5$ & 7 & 35 \\
\hline & & Riparian & 4 & 4 & $6-7$ & 47 \\
\hline & & Developed & 1 & 5 & 7 & 12 \\
\hline \multirow[t]{5}{*}{ Line transect } & Calabazas & Semi-desert grassland & 3 & 0 & $3-4$ & 10 \\
\hline & Guevavi & Semi-desert grassland & 1 & 0 & 4 & 4 \\
\hline & Tumacácori & Mesquite bosque & 2 & 0 & 4 & 8 \\
\hline & & Riparian & 3 & 0 & $3-4$ & 11 \\
\hline & & Developed & 1 & 0 & 4 & 4 \\
\hline \multirow[t]{4}{*}{ Nocturnal } & Calabazas & Semi-desert grassland & 1 & 0 & 2 & 2 \\
\hline & Guevavi & Semi-desert grassland & 1 & 0 & 2 & 2 \\
\hline & Tumacácori & Mesquite bosque & 2 & 3 & 2 & 10 \\
\hline & & Developed & 1 & 3 & 2 & 5 \\
\hline
\end{tabular}

a Number of stations multiplied by number of visits.

\section{Community Types}

To facilitate interpretation of results, we grouped survey stations and sections into bird community types. We used Ward's hierarchical cluster sampling (McGarigal et al. 2000) using the total number of detections of all bird species at each station from VCP surveys. Clustering is a multivariate classification technique useful in grouping samples that share similar species assemblages (McGarigal et al. 2000). We identified four community types: semi-desert grassland, mesquite bosque, riparian, and developed. For a description of all community types (except the developed type) see the Vegetation section in Chapter 2. The developed community type at the Tumacácori unit was represented by one station, centered in the courtyard of the Tumacácori Mission; vegetation included scattered mesquite, hackberry, and elderberry and various ornamental trees and shrubs. This was also the only area with bird feeders.

\section{VCP Surveys}

\section{Field Methods}

We used the variable circular-plot (VCP) method to survey for diurnally active birds during the breeding season (Reynolds et al. 1980, Buckland et al. 1993). Conceptually, these surveys are similar to traditional "point counts" (Ralph et. al 1995) during which an observer spends a standardized length of time at one location and records all birds seen or heard and the distance to each bird or group of birds.

We established one transect in 2001 at the Tumacácori unit ( 8 stations) and one transect each at the Calabazas ( 3 stations) and Guevavi (2 stations) units in 2002 (Table 6.1; Figs. 6.1, 6.2). Stations along each transect were a minimum of $250 \mathrm{~m}$ apart to maintain independence among observations at each station. Each year we surveyed from April through July, the period of peak breeding activity for most species in southern Arizona. The number of annual visits to each station varied slightly in some cases, but we maintained a minimum of 10 days between surveys. On each visit we alternated observers and the order in which we surveyed stations (along a transect) to minimize bias by observer, time of day, and direction of travel. We began bird surveys approximately 30 minutes before sunrise and concluded no later than four hours after sunrise, or when bird activity decreased markedly. We did not survey when winds exceeding $15 \mathrm{~km} / \mathrm{h}$ or when precipitation exceeded an intermittent drizzle.

We recorded a number of environmental variables prior to beginning each transect: wind speed category (Beaufort scale), presence and severity of rain (qualitative assessment), 
air temperature $\left({ }^{\circ} \mathrm{F}\right)$, relative humidity $(\%)$, and cloud cover (\%). After arriving at a station, we waited for one minute before beginning the count to allow birds to resume their normal activities. We identified (to species) all birds seen or heard during an eight-minute "active" period. For each detection, we recorded its distance in meters from the observer (measured with laser range finder when possible), time of detection (measured in oneminute intervals beginning at the start of the active period), and the sex and/or age class (adult or juvenile) if known. We did not measure distances to birds that were seen flying overhead, nor did we use techniques to attract birds (e.g., "pishing"). We made an effort to avoid double-counting individuals that had been recorded at previous stations. If we observed a species during the "passive" count period (between the eight-minute counts), and which had not been recorded previously at a station on that visit, we recorded its distance to the nearest station.

\section{Effort}

We visited eight stations at the Tumacácori unit from four to seven times each in both 2001 and 2002 (Table 6.1). We visited the stations at the Calabazas and Guevavi units (three and two stations, respectively) five times each in 2002. We visited each park unit at least five times, and visited stations representing each community type at least 12 times over the two-year period.

\section{Analysis}

We calculated relative abundance of each species in each community type as the total number of detections at all stations and visits, divided by effort (the number of stations multiplied by the number of visits) for 53 of the most common species. We reduced our full collection of observations from the two years of the study $(n=2,360)$ to a subset of data $(n=1,282)$ more appropriate for estimating relative abundance. First, we used only those detections that occurred $\leq 75 \mathrm{~m}$ from each count station (thereby excluding 586 observations) to facilitate comparisons of relative abundance of species, both within and among community types. We truncated observations because the probability of detecting an individual is a function of both the conspicuousness of the species (ranging from loud and highly visible [e.g., the Gila woodpecker] to the quiet [e.g., the varied bunting]) (Verner and Ritter 1983) and the structure of the vegetation. By truncating we assume that all individuals within $75 \mathrm{~m}$ of all stations can be detected with equal probability. We excluded additional observations to further standardize data for comparative purposes: birds flying over stations (255 observations), birds observed outside of the eight-minute count period (278 observations), unknown species except ravens (35 observations), and instances when an observer failed to record a distance (4 observations). In addition, we excluded 38 species that were recorded on fewer than two occasions in both years (52 observations); these species were not reliable components of the bird community but are included in our species list for the park (Appendix D). Some observations met more than one of these criteria for exclusion from analyses.

We modified the relative abundance estimates for six species that arrived at the park later in the breeding season (yellow-billed cuckoo, blue grosbeak, and varied bunting) or left early (Wilson's warbler, green-tailed towhee, and white-crowned sparrow; see Appendix T for arrival and departure time periods). For these species we used a sample size of one-half of that used for the other species to estimate their relative abundance in each community type. The results for these species (Table 6.2), therefore, should be interpreted as relative abundance during half of the breeding season, and not as the mean across the entire season as applies to the other species.

\section{Line-transect Surveys}

\section{Field Methods}

We used a modified line-transect method (Bibby et al. 2000) to survey for birds in all units from November 2002 to January 2003. Line transects differ from station transects (such as those used in our VCP surveys) in that an observer records birds seen or heard while 
the observer walks an envisioned transect line, rather than by standing at a series of stations. The transect method is more effective during the non-breeding season because bird vocalizations are less conspicuous and frequent, and therefore birds tend to be less visible (Bibby et al. 2000).

At Tumacácori NHP we established transects along trails or in areas that provided relatively easy walking; observers needed to focus on detecting birds rather than on footing or obstacles. We divided transects into sections of approximately $250 \mathrm{~m}$ in length. Section breaks corresponded with VCP station locations (Figs. 6.1, 6.2). To account for seasonal variation in bird distribution and abundance, we visited each transect four times with about three weeks between each visit. As with other survey methods, we alternated observers and direction of travel along transects to reduce biases, and did not survey during periods of excessive rain or wind (see VCP survey methods for details).

We began surveys about 30 minutes after sunrise and continued until all transect sections (in all three units) were completed. As with VCP surveys, we recorded weather conditions at the beginning and end of each survey. Prior to beginning a section, we recorded the section name (e.g., "A-B") and the start time.

For ten minutes we recorded all birds seen and/or heard within each section (i.e., we timed our travel so that we traversed the section in ten minutes) using the following distance categories: $<100 \mathrm{~m}$, $>100 \mathrm{~m}$, or "flyover." When possible we noted sex and age class of birds. We recorded birds observed before or after surveys as "incidentals" (see section below), and we did not use techniques to attract birds (e.g., "pishing").

\section{Effort}

We visited ten line-transect sections three to four times in the fall/winter of 2002-2003 $(n=$ 37 surveys; Table 6.1). Each unit and community type was visited four times.
Analysis

We used the same community types identified for VCP surveys, because the location of sections breaks and VCP stations were the same. To estimate relative abundance we used only detections that occurred within $100 \mathrm{~m}$ of the transect line in an effort to reduce bias associated with varying detectability (see details in VCP section). We calculated relative abundance using the same method as for VCP surveys and report detections in the "> $100 \mathrm{~m}$ " and "flyover" categories in Appendix D.

\section{Nocturnal Surveys}

\section{Field Methods}

To survey for owls we broadcasted commercially available vocalizations (Colver et al. 1999) using a compact disc player and broadcaster (Bibby et al. 2000), and recorded other nocturnal species (nighthawks and poorwills) when heard. We established one nocturnal survey transect along a road or trail in each park unit (Table 6.1, Figs. 6.1, 6.2). The number of stations varied from one to three per transect and stations were a minimum of $300 \mathrm{~m}$ apart. As with other survey methods, we varied observers and direction of travel along transects and did not survey during periods of excessive rain or wind. We began surveys approximately 45 minutes after sunset.

We began surveys at each station with a threeminute "passive" listening period during which time we broadcasted no calls. We then broadcasted vocalizations for a series of twominute "active" periods. We used vocalizations of species we thought, based on habitat requirements and range, might be present: burrowing owls at Calabazas and Guevavi units; elf, western screech, and barn owls at all three units. We broadcasted recordings of owls in sequence from smallest to largest size species so that smaller species would not be inhibited by the "presence" of larger predators or competitors (Fuller and Mosher 1987). During active periods, we broadcasted owl vocalizations for 30 seconds followed by a 30 -second listening period. This pattern was repeated two times for each species. We excluded great horned owl from 
the broadcast sequence because of their aggressive behavior toward other owls. We did not specifically survey for any species listed as threatened or endangered (e.g., the cactus-ferruginous pygmy owl [Glaucidium brasilianum cactorum]) because such species require specific protocols for surveying.

During the count period, we used a flashlight to scan nearby vegetation for visual detections. If we observed a bird during the three-minute passive period, we recorded the minute of the passive period in which the bird was first observed, the type of detection (aural, visual or both), and the distance to the bird. If we observed a bird during any of the two-minute active periods, we recorded in which interval(s) it was detected and the type of detection (aural, visual or both). As with other survey types, we attempted to avoid doublecounting individuals recorded at previous stations. We also used multiple observers, alternated direction of travel, and did not survey during inclement weather.

\section{Effort}

We surveyed at five nocturnal survey stations from two to five times in 2001 and $2002(n=$ 19 surveys), and surveyed each unit at least twice and each community type (except riparian) at least four times (Table 6.1).

\section{Analysis}

We report the total number of detections by unit; sample size was inadequate for calculating meaningful estimates of relative abundance.

\section{Incidental and Breeding Observations}

\section{Field Methods}

When we were not conducting formal surveys and we encountered a species of interest, a species in an unusual location, or an individual displaying breeding behavior, we recorded UTM coordinates, time of detection, and (if known) the sex and age class of the bird. We noted all breeding-behavior observations using a standardized classification system (NAOAC 1990), which characterizes breeding behavior into one of nine categories: adult carrying nesting material, nest building, adult performing distraction display, used nest, fledged young, occupied nest, adult carrying food, adult feeding young, or adult carrying a fecal sac.

\section{Analysis}

We provide frequency counts for species observed incidentally but do not calculate relative abundance as we did for VCP and linetransect surveys. We report results of incidental observations by park unit. For breeding behavior observations we summarize the number of observations in each category, by park unit.

\section{Vegetation Sampling at VCP Stations}

We sampled vegetation near each VCP survey station to characterize vegetation. These data could be used to help determine habitat associations for specific bird species and identify important features of species-rich communities at the park. We sampled vegetation at five subplots located at a modified random direction and distance from each station. Each plot was located within a $72^{\circ}$ range of the compass from the station (e.g., Plot 3 was located between $145^{\circ}$ and $216^{\circ}$ ) to reduce clustering of plots. We randomly placed plots within $75 \mathrm{~m}$ of the stations to correspond with truncation of data used in estimating relative abundance.

At each plot we used the point-quarter method (Krebs 1998) to sample vegetation by dividing the plot into four quadrants along cardinal directions. We applied this method to plants in three height categories: sub-shrubs (0.5-1.0 $\mathrm{m})$, shrubs $(>1.0-2.0 \mathrm{~m})$, trees $(>2.0 \mathrm{~m})$, and one size category: potential cavity-bearing vegetation (>20 cm diameter at breast height). If there was no vegetation for a given category within $25 \mathrm{~m}$ of the plot center, we indicated this in the species column. For each individual plant, we recorded distance from the plot center, species, height, and maximum canopy diameter (including errant branches). Association of a plant to a quadrant was determined by the location of its trunk, regardless of which quadrant the majority of 
the plant was in; no plant was recorded in more than one quadrant. Standing dead vegetation was only recorded in the "potential cavitybearing tree" category. On rare occasions when plots overlapped we repeated the selection process for the second plot.

Within a 5-m radius around the center of each plot, we visually estimated (1) percent ground cover by type (bare ground, litter, or rock); and (2) percent aerial cover of vegetation in each quadrant using three height categories: $0-0.5$ $\mathrm{m},>0.5-2.0 \mathrm{~m}$, and $>2.0 \mathrm{~m}$. For both estimates we used one of six categories for percent cover: " 0 " $(0 \%)$, " 10 " (1-20\%), “30" (21-40\%), "50” (41-60\%), "70" (61-80\%), and "90" (81-100\%).

\section{Analysis}

We collected these data to characterize gross vegetation characteristics around each survey station. In the event that future bird surveys detect marked changes in species or communities, the vegetation data reported in Appendix U will provide potential explanatory variables.

\section{Results}

\section{Species Richness}

We recorded 146 species during the two years of the study (considering all detections and survey types; Appendix D). Although comparisons among units may be biased by unequal survey effort, species richness was highest at the Tumacácori unit $(n=129)$, lower at the Calabazas unit $(n=80)$ and lowest at the Guevavi unit $(n=74)$. We recorded 50 species at all three units and 59 species at only one of the three units (Appendix D). All three nonnative species that we found during this study (rock pigeon, European starling, and house sparrow) were recorded at the Tumacácori unit, whereas only one (European starling) was recorded at the Calabazas unit and no nonnatives were recorded at the Guevavi unit. Neotropical migrant species made up 71\% $(n=$ 103) of all species recorded (Appendix D).

\section{VCP Surveys}

We recorded 104 species during VCP surveys in 2001 and 2002. Considering all species recorded at each station (including those observations that we eliminated from estimation of relative abundance, as described in the methods sections), species richness varied little among stations in each community type: mesquite bosque ( $n=71$ species), semidesert grasslands ( $n=69$ species), riparian $(n=$ 63 species), and developed (57 species). We found 34 species that were unique to a single community type while an equal number of species were recorded in all community types (Appendix D). The number of species unique to a community type was highest for semidesert grassland stations ( $n=14$ species) and fewest for the developed station $(n=4$ species).

Among the stations in each of the four community types, house sparrows were most abundant and were recorded predominantly in the developed community type (Table 6.2). Other abundant species at the developed station included the vermilion flycatcher and phainopepla. At the mesquite bosque stations, the yellow-breasted chat, Bell's vireo, and Lucy's warbler were most abundant; at the adjacent riparian stations, the yellow-breasted chat, Bewick's wren, and song sparrow were the most abundant. At the Calabazas and Guevavi units, representing the semi-desert grassland community type, the Lucy's warbler and Bewick's wren were the most abundant (Table 6.2).

\section{Line-transect Surveys}

We recorded 56 species during line-transect surveys in the three park units (Table 6.3). Species richness was highest in the semi-desert grasslands (23 species) and lower in the other community types (21 species each). The most abundant species in each community type were: the chipping and white-crowned sparrows in the mesquite bosque; the European starling and white-crowned sparrow in the developed; the yellow-rumped warbler and chipping sparrow in the riparian; and the 
Table 6.2. Relative abundance of birds recorded during VCP surveys, all units, Tumacácori NHP, 2001-2002. See Methods section for details on estimation of relative abundance and Table 6.1 for effort per community type. See Appendix D for scientific names.

\begin{tabular}{|c|c|c|c|c|c|c|c|c|c|c|c|c|}
\hline \multirow[b]{3}{*}{ Common name } & \multicolumn{12}{|c|}{ Community type } \\
\hline & \multicolumn{3}{|c|}{$\begin{array}{c}\text { Developed } \\
(n=12)\end{array}$} & \multicolumn{3}{|c|}{$\begin{array}{l}\text { Mesquite bosque } \\
(n=35)\end{array}$} & \multicolumn{3}{|c|}{$\begin{array}{c}\text { Riparian } \\
(n=43) \\
\end{array}$} & \multicolumn{3}{|c|}{$\begin{array}{c}\text { Semi-desert } \\
\text { grassland }(n=25)\end{array}$} \\
\hline & $n$ & Mean & SE & $n$ & Mean & $\mathrm{SE}$ & $n$ & Mean & SE & $n$ & Mean & $\mathrm{SE}$ \\
\hline gray hawk & & & & & & & 3 & $<0.1$ & 0.04 & & & \\
\hline Gambel's quail & 1 & $<0.1$ & 0.08 & 5 & 0.1 & 0.08 & & & & 3 & 0.1 & 0.09 \\
\hline white-winged dove & 9 & 0.8 & 0.28 & 14 & 0.4 & 0.10 & 24 & 0.6 & 0.11 & 5 & 0.2 & 0.12 \\
\hline mourning dove & 6 & 0.5 & 0.23 & 7 & 0.2 & 0.07 & 15 & 0.4 & 0.08 & 8 & 0.3 & 0.11 \\
\hline Inca dove & 3 & 0.3 & 0.13 & & & & & & & & & \\
\hline common ground-dove & 4 & 0.3 & 0.33 & 2 & $<0.1$ & 0.04 & & & & 4 & 0.2 & 0.09 \\
\hline yellow-billed cuckoo a & 1 & 0.2 & 0.17 & 1 & $<0.1$ & 0.06 & 2 & 0.1 & 0.07 & 1 & $<0.1$ & 0.08 \\
\hline broad-billed hummingbird & & & & 16 & 0.5 & 0.13 & 3 & $<0.1$ & 0.04 & 2 & $<0.1$ & 0.06 \\
\hline black-chinned hummingbird & 1 & $<0.1$ & 0.08 & 2 & $<0.1$ & 0.04 & 8 & 0.2 & 0.06 & 4 & 0.2 & 0.07 \\
\hline Gila woodpecker & 8 & 0.7 & 0.26 & 11 & 0.3 & 0.09 & 35 & 0.8 & 0.14 & 5 & 0.2 & 0.10 \\
\hline ladder-backed woodpecker & 2 & 0.2 & 0.11 & 5 & 0.1 & 0.06 & 14 & 0.3 & 0.09 & 4 & 0.2 & 0.07 \\
\hline northern flicker & 1 & $<0.1$ & 0.08 & & & & 4 & 0.1 & 0.06 & & & \\
\hline northern beardless-tyrannulet & & & & 2 & $<0.1$ & 0.04 & & & & 3 & 0.1 & 0.07 \\
\hline Say's phoebe & 11 & 0.9 & 0.19 & & & & & & & & & \\
\hline vermilion flycatcher & 19 & 1.6 & 0.19 & 4 & 0.1 & 0.07 & 5 & 0.1 & 0.05 & 2 & $<0.1$ & 0.06 \\
\hline dusky-capped flycatcher & & & & & & & 6 & 0.1 & 0.05 & & & \\
\hline ash-throated flycatcher & 3 & 0.3 & 0.18 & 2 & $<0.1$ & 0.04 & 6 & 0.1 & 0.07 & 7 & 0.3 & 0.09 \\
\hline brown-crested flycatcher & 2 & 0.2 & 0.11 & 6 & 0.2 & 0.08 & 24 & 0.6 & 0.12 & 8 & 0.3 & 0.10 \\
\hline Cassin's kingbird & 4 & 0.3 & 0.19 & 1 & $<0.1$ & 0.03 & 10 & 0.2 & 0.09 & 1 & $<0.1$ & 0.04 \\
\hline western kingbird & 2 & 0.2 & 0.17 & 3 & 0.1 & 0.06 & & & & & & \\
\hline Bell's vireo & 1 & $<0.1$ & 0.08 & 48 & 1.4 & 0.12 & 1 & $<0.1$ & 0.02 & 10 & 0.4 & 0.12 \\
\hline bridled titmouse & & & & & & & 18 & 0.4 & 0.09 & & & \\
\hline verdin & 5 & 0.4 & 0.26 & 29 & 0.8 & 0.13 & & & & 5 & 0.2 & 0.10 \\
\hline Bewick's wren & 12 & 1.0 & 0.35 & 26 & 0.7 & 0.12 & 39 & 0.9 & 0.13 & 18 & 0.7 & 0.16 \\
\hline blue-gray gnatcatcher & & & & & & & 1 & $<0.1$ & 0.02 & 2 & $<0.1$ & 0.06 \\
\hline northern mockingbird & 1 & $<0.1$ & 0.08 & 2 & $<0.1$ & 0.04 & & & & 1 & $<0.1$ & 0.04 \\
\hline curve-billed thrasher & 4 & 0.3 & 0.14 & 5 & 0.1 & 0.06 & & & & & & \\
\hline phainopepla & 16 & 1.3 & 0.41 & 26 & 0.7 & 0.15 & 13 & 0.3 & 0.09 & 12 & 0.5 & 0.13 \\
\hline Lucy's warbler & 7 & 0.6 & 0.23 & 39 & 1.1 & 0.15 & 16 & 0.4 & 0.09 & 27 & 1.1 & 0.18 \\
\hline yellow warbler & & & & 2 & $<0.1$ & 0.04 & 24 & 0.6 & 0.11 & & & \\
\hline common yellowthroat & & & & 2 & $<0.1$ & 0.04 & 16 & 0.4 & 0.11 & & & \\
\hline Wilson's warbler a & 1 & 0.2 & 0.17 & 4 & 0.2 & 0.18 & 3 & 0.1 & 0.08 & 2 & 0.2 & 0.10 \\
\hline yellow-breasted chat & & & & 54 & 1.5 & 0.25 & 51 & 1.2 & 0.18 & 8 & 0.3 & 0.11 \\
\hline summer tanager & 1 & $<0.1$ & 0.08 & 8 & 0.2 & 0.07 & 29 & 0.7 & 0.12 & 5 & 0.2 & 0.08 \\
\hline western tanager & 1 & $<0.1$ & 0.08 & 2 & $<0.1$ & 0.04 & 3 & $<0.1$ & 0.05 & & & \\
\hline green-tailed towhee a & & & & & & & & & & 1 & $<0.1$ & 0.08 \\
\hline canyon towhee & & & & & & & & & & 4 & 0.2 & 0.07 \\
\hline Abert's towhee & 1 & $<0.1$ & 0.08 & 7 & 0.2 & 0.08 & 3 & $<0.1$ & 0.04 & & & \\
\hline rufous-winged sparrow & 1 & $<0.1$ & 0.08 & 6 & 0.2 & 0.06 & & & & 3 & 0.1 & 0.07 \\
\hline rufous-crowned sparrow & & & & & & & & & & 4 & 0.2 & 0.07 \\
\hline black-throated sparrow & & & & & & & & & & 7 & 0.3 & 0.14 \\
\hline song sparrow & 1 & $<0.1$ & 0.08 & 1 & $<0.1$ & 0.03 & 36 & 0.8 & 0.14 & 1 & $<0.1$ & 0.04 \\
\hline white-crowned sparrow a & 2 & 0.3 & 0.33 & & & & & & & & & \\
\hline northern cardinal & 10 & 0.8 & 0.21 & 34 & 1.0 & 0.12 & 4 & 0.1 & 0.04 & 12 & 0.5 & 0.14 \\
\hline blue grosbeak a & 2 & 0.3 & 0.21 & 6 & 0.3 & 0.14 & 2 & 0.1 & 0.07 & 3 & 0.2 & 0.17 \\
\hline varied bunting a & & & & 3 & 0.2 & 0.09 & 1 & $<0.1$ & 0.05 & 2 & 0.2 & 0.15 \\
\hline great-tailed grackle & 8 & 0.7 & 0.19 & 1 & $<0.1$ & 0.03 & & & & & & \\
\hline brown-headed cowbird & 1 & 0.1 & 0.08 & 21 & 0.6 & 0.17 & 19 & 0.4 & 0.10 & 8 & 0.3 & 0.10 \\
\hline hooded oriole & 1 & 0.1 & 0.08 & 1 & $<0.1$ & 0.03 & 2 & $<0.1$ & 0.05 & 1 & $<0.1$ & 0.04 \\
\hline Bullock's oriole & 1 & 0.1 & 0.08 & 4 & 0.1 & 0.07 & & & & 3 & 0.1 & 0.09 \\
\hline house finch & 15 & 1.3 & 0.30 & 7 & 0.2 & 0.07 & 4 & 0.1 & 0.04 & 6 & 0.2 & 0.09 \\
\hline lesser goldfinch & 3 & 0.3 & 0.13 & 14 & 0.4 & 0.12 & 15 & 0.4 & 0.09 & 4 & 0.2 & 0.07 \\
\hline
\end{tabular}




\begin{tabular}{|c|c|c|c|c|c|c|c|c|c|c|c|c|}
\hline \multirow[b]{3}{*}{ Common name } & \multicolumn{12}{|c|}{ Community type } \\
\hline & \multicolumn{3}{|c|}{$\begin{array}{l}\text { Developed } \\
(n=12)\end{array}$} & \multicolumn{3}{|c|}{$\begin{array}{c}\text { Mesquite bosque } \\
(n=35)\end{array}$} & \multicolumn{3}{|c|}{$\begin{array}{l}\text { Riparian } \\
(n=43)\end{array}$} & \multicolumn{3}{|c|}{$\begin{array}{c}\text { Semi-desert } \\
\text { grassland }(n=25)\end{array}$} \\
\hline & $n$ & Mean & SE & $n$ & Mean & SE & $n$ & Mean & SE & $n$ & Mean & SE \\
\hline house sparrow & 32 & 2.7 & 1.01 & 1 & $<0.1$ & 0.03 & & & & & & \\
\hline
\end{tabular}

chipping sparrow and mourning dove in the semi-desert grassland (Table 6.3).

Excluding incidental observations and nocturnal records from both seasons, we recorded 13 species $(26 \%)$ during line-transect surveys that we did not record during the VCP surveys. Conversely, we recorded 68 species $(65 \%)$ during VCP surveys that we did not record during line-transect surveys.

\section{Nocturnal Surveys}

We recorded three species of owls and one common poorwill at the Guevavi unit, two species of owl at the Tumacácori unit and no species at the Calabazas unit. All four nocturnal species at the Guevavi unit were recorded during one survey. We detected the barn owl twice at the Tumacácori unit and once at the Guevavi unit; the western screech owl seven times at the Tumacácori unit and twice at the Guevavi unit; and the elf owl and the common poorwill once and three times, respectively, at the Guevavi unit.

\section{Incidental and Breeding Observations}

We recorded incidental observations of 121 species at the park: 60 species at the Calabasas unit, 50 species at the Guevavi unit, and 100 species at the Tumacácori unit. We recorded 41 species that were not recorded during another survey type.

We confirmed breeding for 32 species based on 72 observations of breeding behavior or evidence (Table 6.4). The highest number of species $(n=27)$ for which breeding was confirmed was at the Tumacácori unit, and the most records for an individual species (vermilion flycatcher; $n=9$ ) were also at the Tumacácori unit. The fewest number of species confirmed as breeders $(n=6)$ were recorded at the Guevavi unit, though two of these (Inca dove and common ground dove) were not recorded as breeding in either of the other units (Appendix U). Similarly, we observed evidence of breeding in three species at the Calabazas unit (lark sparrow, blackthroated sparrow, and blue grosbeak) that were not observed in the other two units. We found two nests (one each of the Bell's vireo and vermilion flycatcher) where adults were feeding brown-headed cowbird young.

\section{Inventory Completeness}

Based on the species accumulation curve, which shows the number of new species reaching an asymptote, we believe that we have recorded $>90 \%$ of the species that breed in and around the park or that stopover for a significant amount of time during the time of the VCP surveys (Fig. 6.3). However, based on the high bird species richness and the diversity of vegetation components at the park, we believe that the bird inventory is not complete and is likely missing spring and fall migrants and winter residents (Fig. 6.3). There are at least 40 species that were not recorded by us, MAPS personnel, or other researchers or observers, but which are likely to be recorded at Tumacácori NHP with additional survey effort (Appendix H; see Recommendations section for suggestions for completing inventories).

\section{Discussion}

This bird inventory is an important step in understanding the valuable role of the park and surrounding lands in providing habitat for birds. With moderate search effort (approximately 20 field days over two years) we recorded 146 species, several of which 
Table 6.3. Relative abundance of birds recorded during line-transect surveys, all units, Tumacácori NHP, 2002-2003. See Methods section for details on estimation of relative abundance and Table 6.1 for effort per community type. See Appendix D for scientific names.

\begin{tabular}{|c|c|c|c|c|c|c|c|c|c|c|c|c|}
\hline \multirow[b]{3}{*}{ Common name } & \multicolumn{12}{|c|}{ Community type } \\
\hline & \multicolumn{3}{|c|}{$\begin{array}{l}\text { Developed } \\
(n=4)\end{array}$} & \multicolumn{3}{|c|}{$\begin{array}{l}\text { Mesquite bosque } \\
(n=8)\end{array}$} & \multicolumn{3}{|c|}{$\begin{array}{r}\text { Riparian } \\
(n=11) \\
\end{array}$} & \multicolumn{3}{|c|}{$\begin{array}{l}\text { Semi-desert grassland } \\
\qquad(n=14)\end{array}$} \\
\hline & $\mathrm{n}$ & Mean & SE & $\mathrm{n}$ & Mean & SE & $\mathrm{n}$ & Mean & SE & $\mathrm{n}$ & Mean & SE \\
\hline great egret & & & & & & & 1 & 0.1 & 0.09 & & & \\
\hline Cooper's hawk & & & & & & & 1 & 0.1 & 0.09 & & & \\
\hline red-tailed hawk & 1 & 0.3 & 0.25 & & & & 1 & 0.1 & 0.09 & 2 & 0.1 & 0.10 \\
\hline mourning dove & & & & & & & & & & 12 & 0.9 & 0.42 \\
\hline common ground-dove & & & & & & & 1 & 0.1 & 0.09 & & & \\
\hline greater roadrunner & & & & 1 & 0.1 & 0.13 & & & & & & \\
\hline Gila woodpecker & 1 & 0.3 & 0.25 & & & & 7 & 0.6 & 0.28 & 3 & 0.2 & 0.11 \\
\hline ladder-backed woodpecker & & & & & & & & & & 1 & 0.1 & 0.07 \\
\hline hairy woodpecker & & & & 1 & 0.1 & 0.13 & & & & & & \\
\hline northern flicker & 1 & 0.3 & 0.25 & 2 & 0.3 & 0.16 & 3 & 0.3 & 0.19 & 4 & 0.3 & 0.22 \\
\hline gray flycatcher & & & & & & & & & & 1 & 0.1 & 0.07 \\
\hline black phoebe & & & & & & & 3 & 0.3 & 0.14 & & & \\
\hline Say's phoebe & 4 & 1.0 & 0.71 & 2 & 0.3 & 0.16 & & & & & & \\
\hline vermilion flycatcher & & & & 1 & 0.1 & 0.13 & & & & & & \\
\hline ash-throated flycatcher & & & & 1 & 0.1 & 0.13 & & & & 1 & 0.1 & 0.07 \\
\hline Cassin's kingbird & 1 & 0.3 & 0.25 & & & & & & & & & \\
\hline solitary vireo type & & & & & & & 1 & 0.1 & 0.09 & & & \\
\hline unknown raven & & & & & & & 1 & 0.1 & 0.09 & 6 & 0.4 & 0.25 \\
\hline bridled titmouse & & & & 4 & 0.5 & 0.33 & 7 & 0.6 & 0.31 & & & \\
\hline verdin & 3 & 0.8 & 0.25 & 9 & 1.1 & 0.30 & 3 & 0.3 & 0.14 & 6 & 0.4 & 0.23 \\
\hline rock wren & & & & & & & & & & 1 & 0.1 & 0.07 \\
\hline Bewick's wren & 5 & 1.3 & 0.48 & 10 & 1.3 & 0.31 & 8 & 0.7 & 0.27 & 8 & 0.6 & 0.20 \\
\hline house wren & & & & 1 & 0.1 & 0.13 & 1 & 0.1 & 0.09 & & & \\
\hline ruby-crowned kinglet & 1 & 0.3 & 0.25 & 9 & 1.1 & 0.44 & 7 & 0.6 & 0.24 & 2 & 0.1 & 0.10 \\
\hline blue-gray gnatcatcher & & & & & & & & & & 1 & 0.1 & 0.07 \\
\hline black-tailed gnatcatcher & & & & & & & & & & 1 & 0.1 & 0.07 \\
\hline hermit thrush & & & & & & & 1 & 0.1 & 0.09 & & & \\
\hline American robin & & & & & & & 2 & 0.2 & 0.12 & & & \\
\hline northern mockingbird & & & & & & & & & & 1 & 0.1 & 0.07 \\
\hline European starling & 4 & 1.0 & 1.00 & & & & & & & & & \\
\hline cedar waxwing & 3 & 0.8 & 0.75 & & & & & & & & & \\
\hline yellow-rumped warbler & 3 & 0.8 & 0.75 & 3 & 0.4 & 0.25 & 9 & 0.9 & 0.53 & & & \\
\hline green-tailed towhee & 5 & 1.3 & 0.63 & 1 & 0.1 & 0.13 & & & & & & \\
\hline canyon towhee & & & & & & & & & & 7 & 0.5 & 0.27 \\
\hline Abert's towhee & & & & 5 & 0.6 & 0.32 & 3 & 0.3 & 0.14 & 1 & 0.1 & 0.07 \\
\hline rufous-winged sparrow & 2 & 0.5 & 0.29 & 1 & 0.1 & 0.13 & & & & 9 & 0.6 & 0.29 \\
\hline chipping sparrow & 3 & 0.8 & 0.75 & 6 & 0.8 & 0.62 & 2 & 0.2 & 0.18 & 4 & 0.3 & 0.29 \\
\hline lark sparrow & 1 & 0.3 & 0.25 & & & & & & & & & \\
\hline black-throated sparrow & & & & & & & & & & 7 & 0.5 & 0.25 \\
\hline song sparrow & & & & & & & 3 & 0.3 & 0.14 & 1 & 0.1 & 0.07 \\
\hline white-crowned sparrow & 13 & 3.3 & 1.31 & 6 & 0.8 & 0.62 & & & & & & \\
\hline dark-eyed junco & 1 & 0.3 & 0.25 & & & & & & & & & \\
\hline northern cardinal & 3 & 0.8 & 0.48 & 7 & 0.9 & 0.40 & & & & 2 & 0.1 & 0.10 \\
\hline pyrrhuloxia & 2 & 0.5 & 0.50 & 2 & 0.3 & 0.25 & & & & & & \\
\hline unknown meadowlark & & & & & & & & & & 1 & 0.1 & 0.07 \\
\hline house finch & 2 & 0.5 & 0.50 & & & & & & & 2 & 0.1 & 0.10 \\
\hline lesser goldfinch & & & & 1 & 0.1 & 0.13 & 2 & 0.2 & 0.12 & & & \\
\hline house sparrow & 3 & 0.8 & 0.75 & & & & & & & & & \\
\hline
\end{tabular}


Table 6.4. Observations of breeding behavior by birds, Tumacácori NHP, 2001-2002. Breeding codes follow standards set by NAOAC (1990). See Appendix D for scientific names.

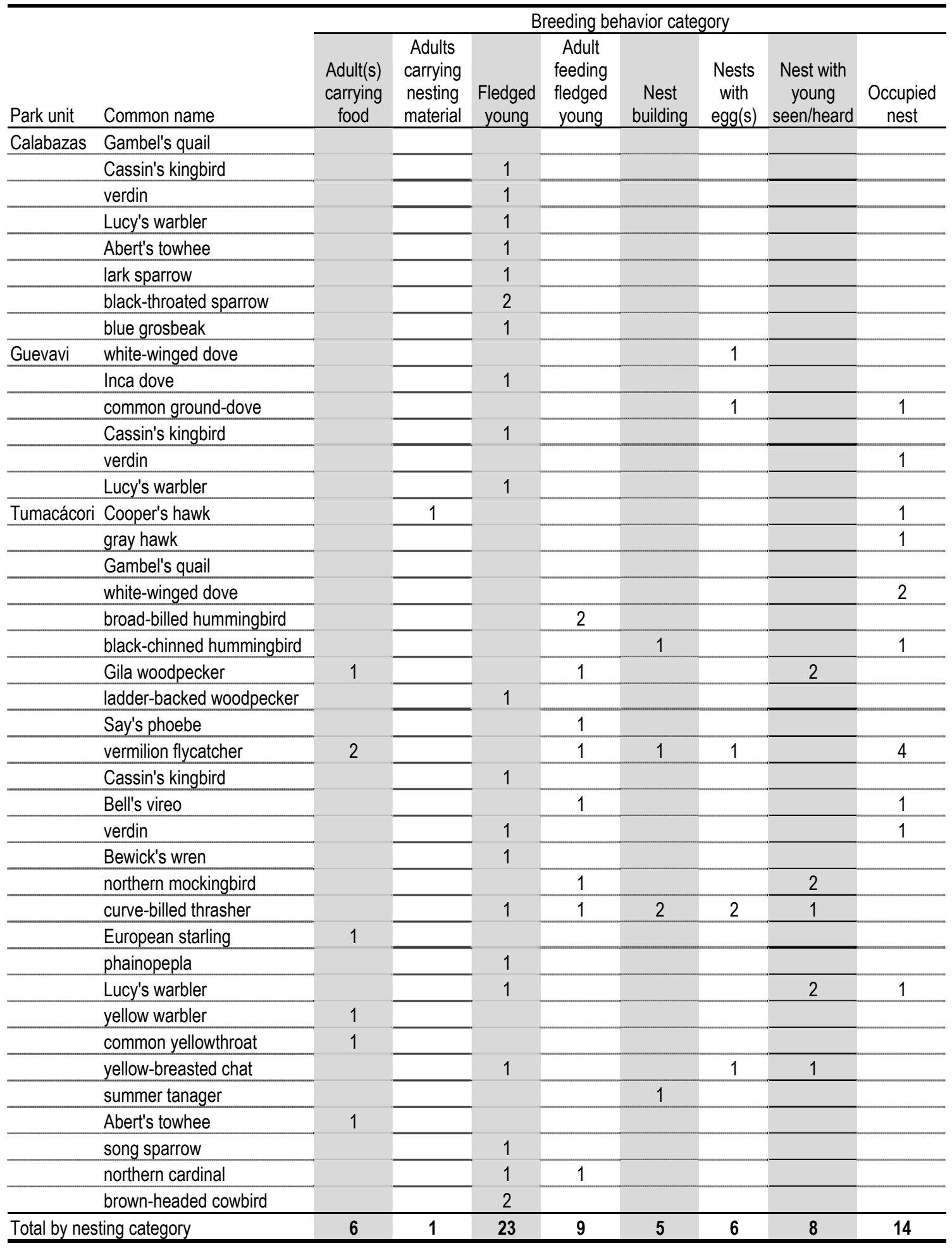




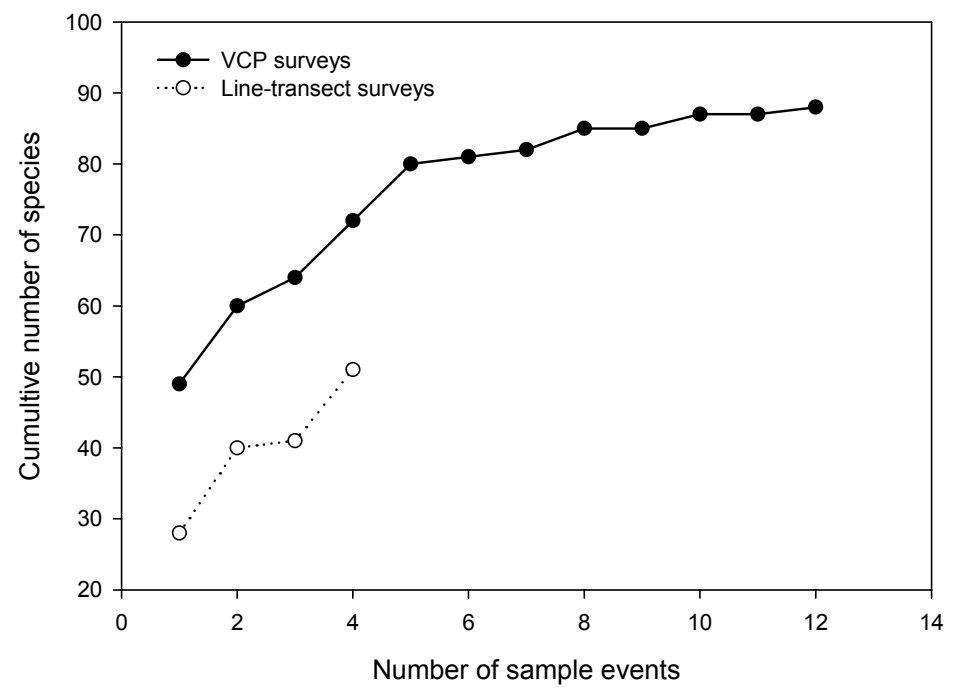

Figure 6.3. Species accumulation curves for number of bird species by sample event (i.e., survey days) for VCP and line-transect surveys, all units, Tumacácori NHP, 2001-2003.

have narrow habitat requirements in the southwest. We do not hesitate to conclude that the park possesses valuable and regionally unique resources for birds and maintains a remarkable avifauna. Seventy percent of the species we recorded were Neotropical migrants (Appendix D). We recorded a number of species of special conservation status (U.S. Fish and Wildlife Service; HDMS 2004): one endangered species (southwestern willow flycatcher); one candidate for endangeredspecies status (yellow-billed cuckoo); and three species of concern (white-faced ibis, gray hawk, and peregrine falcon). The Monitoring Avian Productivity and Survivorship (MAPS) personnel recorded the olive-sided flycatcher (Turner 2003), an additional species of concern.

We recorded only 16 individuals during 19 visits to nocturnal count stations (Table 6.4). Nevertheless, we recorded most of the owl and nightjar species that regularly inhabit the area, except for great horned owl, which was a surprising omission. Based on vegetation characteristics present in the park units, an increased survey effort would likely document all three owl species that we recorded at the Guevavi unit at the other two units, and the great horned owl in all three units. Additional species such as long-eared owl and northern saw-whet owl are possible at all three units. Based on its distribution in southern Arizona and adjacent Sonora, Mexico, the endangered cactus ferruginous pygmy-owl is unlikely to be at the park (Aaron Flesch, pers. comm.).

\section{Cottonwood/Willow Riparian Area}

Tumacácori NHP contains riparian vegetation components that are extremely rare in the southwest, most notably the cottonwood/willow gallery riparian forest (Ohmart 1994). Bird species such as the yellow-billed cuckoo, yellow warbler, common yellowthroat, and song sparrow (Table 6.2) are almost completely reliant on cottonwood/willow forests for nesting habitat in the southwest (Rosenberg et al. 1991). Because of the loss and degradation of this community type across the region (Russell and Monson 1998), the local abundance of these species highlights the importance of the park and surrounding areas for their conservation. Two species in particular are noteworthy: yellow-billed cuckoo and southwestern willow flycatcher (discussed below). 


\section{Yellow-billed Cuckoo}

The riparian area at the Tumacácori unit has one of the highest densities of yellow-billed cuckoos in the western U.S. (Powell 2000). The yellow-billed cuckoo is currently being considered for listing under the Endangered Species Act because of an alarming reduction in its breeding distribution over the last 50 years (Laymon and Halterman 1987, Hughes 1999). We recorded only four yellow-billed cuckoos during our VCP surveys. This low number is not surprising given the inconspicuous behavior of the bird and its late arrival on the breeding ground (Hughes 1999), but this also highlights that the VCP survey method is inappropriate for estimating abundance for this species. Based on the findings by Powell (2000, 2001 unpub. data), more yellow-billed cuckoos were present at the Tumacácori unit than we recorded.

\section{Southwestern Willow Flycatcher}

We recorded one confirmed sighting of the endangered southwestern willow flycatcher along the Santa Cruz River on 25 June 2001. The three other willow flycatchers that we recorded may have been the southwestern subspecies, but this could not be determined. Surveys specifically targeted for the species in 2002 did not locate the southwestern subspecies (Brian Powell, unpub. data; submitted to the Arizona Game and Fish Department). This may have been due to increased numbers of cattle in the riparian area in 2002 and the subsequent reduction of vegetation structure (Brian Powell, pers. obs.). The southwestern subspecies prefers dense understory vegetation for nest sites (Hatten and Paradzick 2003) and it is unclear whether the riparian area at the Tumacácori unit provides adequate breeding habitat for the species.

\section{Mesquite Bosque}

The mesquite bosque plant community once covered large areas of the valley bottoms such as in the Santa Cruz River drainage (Arnold 1940), but due to woodcutting, groundwater pumping, and invasion of tamarisk, this plant community is increasingly rare (Bahre 1991). Bird species inhabiting this community include: the Bell's vireo, Lucy's warbler, yellow-breasted chat, Abert's towhee, and varied bunting (Rosenberg et al. 1991).

\section{Non-native Species}

The abundance of house sparrows in the developed area around the Tumacácori Mission can be problematic for both the native bird species and cultural resources. House sparrows nest in cavities or on ledges (e.g., broken limbs, woodpecker cavities, and cracks in walls; Erlich et al. 1988), and are known to be aggressive toward other cavity-nesting species. At Tumacácori NHP these sparrows may displace cavity-nesters such as the Bewick's wren and Lucy's warblers, can damage cultural resources by enlarging existing cracks, and certainly create a nuisance and distraction via excessive nest material and defecation.

\section{Brown-headed Cowbirds}

The brown-headed cowbird is endemic to the Great Plains and Great Basin regions of the U.S. where it evolved a comensal relationship with the bison (Bison bison) and other large ungulates (Rothstein 1994). Since the arrival of cattle in the southwest, however, brownheaded cowbird populations have thrived (Mehlman 1995). During the breeding season, brown-headed cowbirds prefer edge communities, the abrupt interface of agricultural fields and human development with areas of dense vegetation, particularly along riparian areas (Rothstein 1994) such as at Tumacácori NHP.

Brown-headed cowbirds were abundant at the park during the breeding season in all community types except the developed area (Table 6.2). Brown-headed cowbirds pose a threat to many native birds because they are brood parasites (i.e., lay their eggs in the nests of other species), thereby reducing the productivity of host species. Species particularly susceptible to brown-headed cowbird parasitism include four abundant Neotropical migrants at Tumacácori NHP: Bell's vireo, song sparrow, yellow-breasted chat, and yellow warbler (see review in 
Schwietzer et al. 1998, Averill-Murray et al. 1999, Powell and Steidl 2000). In 2000, B.

Powell (unpub. data) found six yellowbreasted chat nests at the Tumacácori unit that contained at least one cowbird egg each. Brown-headed cowbirds can be controlled by removing habitat (food and foraging sites) and by trapping (which has some success at increasing host productivity [Smith et al. 2002]). Habitat removal is not logistically possible and trapping is currently beyond the limited time and budget of park staff.

Monitoring Avian Productivity and Survivorship Study

The Monitoring Avian Productivity and Survivorship (MAPS) study at the Tumacácori unit provides further evidence of the uniqueness of the bird community in this area (see DeSante et al. 1995 for more information on the program). The MAPS station at the park is located in the mesquite bosque and cottonwood/willow riparian area and has been in operation since 1997. In the seven years of station operation, MAPS personnel have recorded a total of 128 species, 20 of which are not on our species list, including: elegant trogon, worm-eating warbler, ovenbird, and the northern and Louisiana waterthrushes (Turner 2003; Appendix D). Station personnel also noted evidence of breeding for 33 species. 


\section{Chapter 7: Mammal Inventory}

\section{Previous Research}

To our knowledge, there has been no previous mammal research at Tumacácori NHP, though some mammal specimens have been collected from the park (Appendix O).

\section{Methods}

We surveyed for mammals using four field methods: trapping for small terrestrial, nocturnal mammals (primarily rodents, herein referred to as small mammals), infraredtriggered photography for medium and large mammals, investigation of roost sites for bats, and incidental observations for all mammals.

\section{Spatial Sampling Design}

To assign plot locations for most small mammal trapping plots $(n=19)$ we used a simple random design. In addition, we subjectively placed three plots each at the Calabazas and Guevavi units (C1-C3 and G1G3, respectively). We subjectively placed infrared-triggered cameras in areas that we thought would yield the most results (e.g., along animal trails). We searched for bats at roost sites at the Tumacácori Mission.

\section{Small Mammals}

\section{Field Methods}

We trapped small mammals at all three units in 2000 and 2001 (Figs. 7.1, 7.2). We used Sherman ${ }^{\circledR}$ live traps (large, folding aluminum or steel, 3 x 3.5 x 9"; H. B. Sherman, Inc., Tallahassee, FL) set in grids (White et al. 1983), with 10 -m spacing among traps arranged in configurations of five rows and five columns (Calabazas and Guevavi units) or 10 rows and five columns (Tumacácori unit). We opened and baited (one tablespoon; 16 parts dried oatmeal to one part peanut butter) traps in the evening then checked and closed traps the following morning. We placed a small amount of polyester batting in each trap to prevent mortality from the cold. We marked each captured animal with a semi-permanent marker to facilitate recognition; these "batch marks" appeared to last for the duration of the sampling period (one to three days). For each animal we recorded species, sex, age class (adult, subadult, or juvenile), reproductive condition, weight, and measurements for right-hind foot, tail, ear, and head and body. For males, we recorded reproductive condition as either scrotal or non-reproductive. For females we recorded reproductive condition as one or more of the following: non-reproducing, open pubis, closed pubis, enlarged nipples, small or non-present nipples, lactating, post lactating, or not lactating.

Effort

We typically trapped for sampling periods of three nights at all plots (11 at the Tumacácori unit, nine at the Calabazas unit, and five at the Guevavi unit; Figs. 7.1, 7.2). Because of differences in unit size, number of plots, and the number of sprung but empty traps, the number of trap nights (see below for definition) varied by unit: Calabazas $=613$; Guevavi $=382$; Tumacácori $=1,695$.

\section{Analysis}

We summarized data for each unit separately. We calculated relative abundance for species in each unit by dividing the number of captures by the number of trap nights (number of traps multiplied by number of nights they were open) after accounting for sprung traps (misfired or occupied; Beauvais and Buskirk 1999). Sprung traps reduce trap effort because they are no longer "available" to capture animals; we account for this by multiplying the number of sprung traps by 0.5 (lacking specific information, we estimate sprung traps were available for half of the night) (Nelson and Clark 1973).

\section{Note on Sigmodon Species}

During fieldwork we recorded two species of cotton rats (Arizona and yellow-nosed) but verification of our single voucher specimen for the yellow-nosed cotton rat confirmed it as a fulvous cotton rat. Given this uncertainty in 


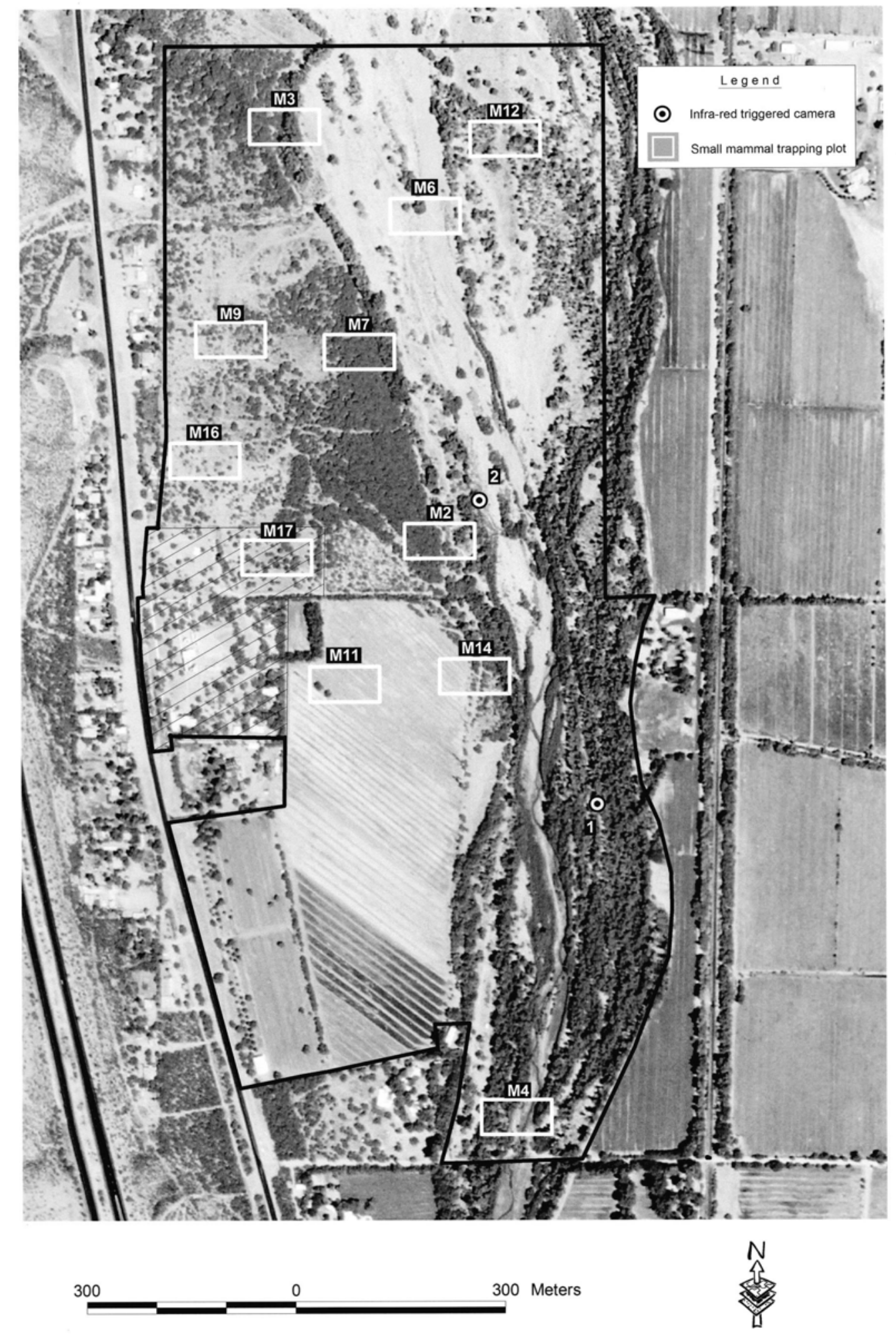

Figure 7.1. Locations of small mammal trapping plots and infrared-triggered cameras, Tumacácori unit, Tumacácori NHP, 2000-2001. See Appendix M for plot coordinates. 

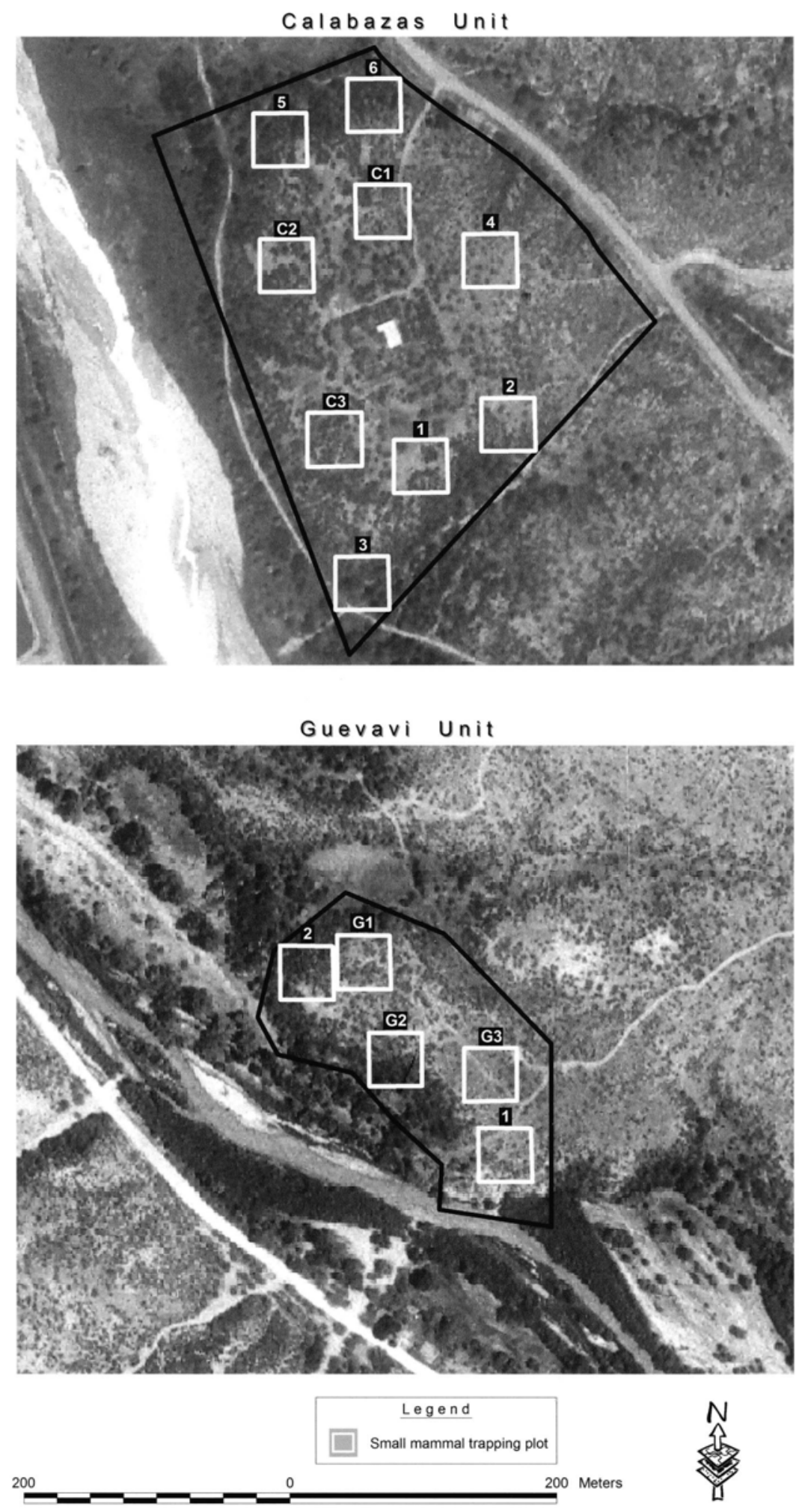

Figure 7.2. Locations of small mammal trapping plots, Calabazas and Guevavi units, Tumacácori NHP, 2000-2001. See Appendix M for plot coordinates. 
field identification of cotton rats we present trapping results for this genus as "cotton rat species."

\section{Infrared-triggered Cameras for Medium and Large Mammals}

\section{Field Methods}

We used infrared-triggered cameras (Trailmaster ${ }^{\circledR}$; model 1500, Goodman and Associates, Inc, Lenexa, KS; Kucera and Barrett 1993) to record the presence of medium and large mammals at the Tumacácori unit only (Fig. 7.1). Trailmasters have three components: a receiver, transmitter, and camera (Fig. 7.3). The transmitter sends an infrared beam to the receiver at a specified rate (5 times per second for this study). The receiver then sends a signal (via cable) to a camera mounted on a tripod 6-8 $\mathrm{m}$ away. When an animal blocks the infrared beam, the camera takes a picture. We set the receiver and transmitter approximately $20 \mathrm{~cm}$ above the ground to ensure that medium and large mammals were captured on film but smaller animals such as rodents and birds were avoided. We cleared sufficient vegetation from the area so as not to disrupt the infrared beam but simultaneously sought to minimize disturbance; animals that regularly use an area might avoid it if there were too much disturbance. We set cameras to take no more than one photograph every five minutes to reduce the chances of recording the same individual more than once (at least on the same occasion). We placed cameras in areas that would capture the most species and highest numbers of animals, typically along trails and near water (e.g., Santa Cruz River; Fig. 7.1). We baited camera sites with a commercial scent lure (ingredients included synthetic catnip oil, bobcat musk, beaver castorium, and propylene glycol as a preservative) or canned cat food. We checked cameras approximately every two weeks to change film and batteries and to ensure their proper function. We photographed a placard documenting the date and camera location on the first exposure of every new roll of film.

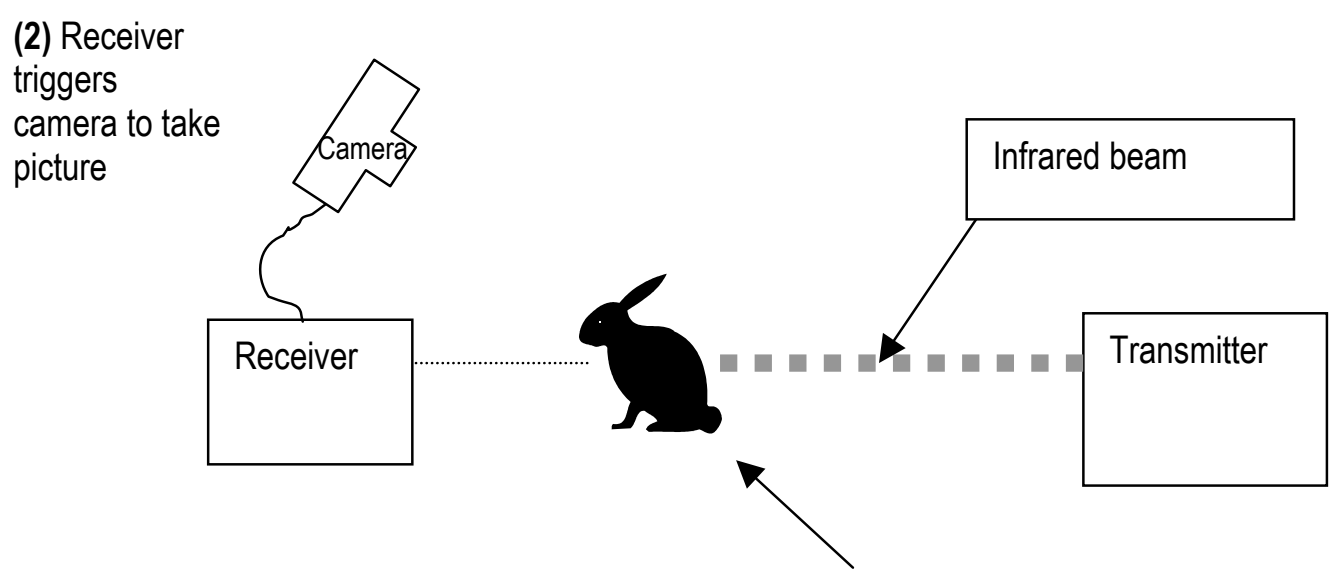

(1) Animal blocks infrared beam from getting to receiver

Figure 7.3. Diagram of infrared-triggered camera set-up. Image based on Swann et al. (2004). 


\section{Analysis}

Infrared-triggered cameras are the most costeffective method for recording the presence of medium and large mammal species (Kucera and Barrett 1993, Cutler and Swann 1999).

However, one drawback to this method is an inability to distinguish among most individuals, which precludes unbiased estimates of abundance (i.e., one must attempt to determine if one animal has been photographed repeatedly or a new individual is in each photo). Notable exceptions are species with distinctive markings that can be differentiated among individuals, such as bobcats (Heilbrun et al. 2003). In some cases, size or physical abnormality may differentiate individuals of any species, but this was not evident frequently enough in our photographs to be useful. Therefore, we report the number of times a species was photographed.

\section{Incidental Observations and Sign}

As with other taxa, we recorded UTM coordinates of mammal sightings. Observers from all field crews (e.g., bird crew as well as mammal crew) recorded mammal sightings and signs such as identifiable tracks or scat, and took photo vouchers when the sign alone was definitive.

\section{Bats}

We visited the Tumacácori unit once, on 2 October 2001, to search for bats in and around the Mission structure. We did not mist net bats at the Santa Cruz River because netting is most efficient when areas of open water are limited, thereby concentrating foraging bats into a small area (Ronnie Sidner, pers. comm.). This was not the case at Tumacácori NHP.

\section{Results}

\section{Small Mammals}

Excluding recaptures, we trapped 477 individuals representing 16 species on a total of 2,689 trap nights in 2000 and 2001 combined (Table 7.1, Appendix E). Species richness was highest at the Calabazas unit $(n=$
12), slightly less at the Tumacácori unit ( $n$ $=11)$, and lowest at the Guevavi unit $(n=9)$. However, the Guevavi unit had the most number of species not recorded at other units ( $n=3$; brush mouse, northern pygmy mouse, and northern grasshopper mouse) although just one individual represented each of these species (Table 7.1).

The desert pocket mouse was the most abundant rodent at both the Calabazas and Guevavi units and the second most abundant at the Tumacácori unit, where the cactus mouse was the most abundant (Table 7.1). The only non-native rodent, the house mouse, was recorded twice at the Calabazas unit, not at all at the Guevavi unit, and 56 times at the Tumacácori unit.

Despite field identification problems for the cotton rats, we trapped at least two species (based on voucher specimens). Based on our field measurements (tail, right-hind foot) it is likely that most of the "unknown cotton rats" were Arizona cotton rats; all but two adults that were originally recorded as "Arizona cotton rat" had measurements that are consistent with that species (Hoffmeister 1986).

\section{Medium and Large Mammals}

We took 70 Trailmaster photographs from which we could identify an animal to genus or species, and those photographs represented 10 species (Table 7.2). Eight of 10 species photographed are represented by five or fewer photographs (Table 7.2). The Virginia opossum was the most frequently photographed species. We photographed all four species of skunks that occur in Arizona.

\section{Bats}

We recorded one species, the pallid bat, during our visit to the Tumacácori unit on 2 October 2001; we heard its distinctive directive calls in the open courtyard on the north side of the mission. Upon inspection of the structure we found a few minor accumulations of guano 
Table 7.1. Total number of small mammals trapped ( $n$ ) and relative abundance (RA), excluding recaptures, by park unit, Tumacácori NHP, 2000-2001.

See text for relative abundance formula. See Appendix E for scientific names.

\begin{tabular}{|c|c|c|c|c|c|c|}
\hline \multirow[b]{2}{*}{ Common name } & \multicolumn{2}{|c|}{ Calabazas } & \multicolumn{2}{|c|}{ Guevavi } & \multicolumn{2}{|c|}{ Tumacácori } \\
\hline & $n$ & RA & $n$ & $\mathrm{RA}$ & $n$ & $\mathrm{RA}$ \\
\hline desert shrew & 1 & 0.2 & & & 2 & 0.1 \\
\hline desert pocket mouse & 56 & 9.1 & 41 & 10.7 & 47 & 2.8 \\
\hline Bailey's pocket mouse & 2 & 0.3 & 1 & 0.3 & & \\
\hline western harvest mouse & & & & & 3 & 0.2 \\
\hline fulvous harvest mouse & 6 & 1.0 & 9 & 2.4 & 1 & 0.1 \\
\hline cactus mouse & 17 & 2.8 & 8 & 2.1 & 76 & 4.5 \\
\hline deer mouse & 4 & 0.7 & & & 15 & 0.9 \\
\hline white-footed mouse & 2 & 0.3 & & & 15 & 0.9 \\
\hline brush mouse ${ }^{a}$ & & & 1 & 0.3 & & \\
\hline northern pygmy mouse & & & 1 & 0.3 & & \\
\hline northern grasshopper mouse ${ }^{a}$ & & & 1 & 0.3 & & \\
\hline southern grasshopper mouse & 18 & 2.9 & 8 & 2.1 & 3 & 0.2 \\
\hline white-throated woodrat & 13 & 2.1 & 14 & 3.7 & 14 & 0.8 \\
\hline unknown cotton-rat ${ }^{\mathrm{b}}$ & 25 & 4.1 & & & 35 & 2.1 \\
\hline house mouse & 2 & 0.3 & & & 56 & 3.3 \\
\hline Total captures & 146 & & 84 & & 247 & \\
\hline Species richness & & & & & & \\
\hline
\end{tabular}

a Identification uncertain- see Discussion section.

${ }^{b}$ We trapped at least two species (Arizona and yellow-nosed) based on identification of voucher specimens. See Methods section for more information.

Table 7.2. Results from infrared-triggered cameras, Tumacácori unit, Tumacácori NHP, 2000-2001.

\begin{tabular}{lc}
\hline Common name & Number of photographs \\
\hline Virginia opossum & 26 \\
\hline northern raccoon & 4 \\
\hline western spotted skunk & 4 \\
\hline striped skunk & 2 \\
\hline hooded skunk & 5 \\
\hline white-backed hog-nosed skunk & 1 \\
\hline feral cat & 4 \\
\hline western white-throated woodrat & 5 \\
\hline unknown cottontail & 5 \\
\hline collared peccary & 14 \\
\hline Total photos & 70 \\
\hline
\end{tabular}

along the east side of the interior of the Mission structure.

\section{Voucher Specimens and Photographs}

We collected 31 voucher specimens representing 15 species of small mammals (Appendix E). With the exception of the above-mentioned cotton rats, vouchers for each identified species were confirmed by Yar Petryszyn (UA mammal collection curator). We did not collect specimen vouchers for two species: brush mouse and northern grasshopper mouse and based on habitat requirements, these identifications may be questionable. We documented black bears at the park by photographing definitive tracks adjacent to the Santa Cruz River.

\section{Inventory Completeness}

We believe that our mammal inventory was most successful in documenting presence of small mammals. We estimate that we 
documented $>90 \%$ of the rodent species likely to occur at the park based on the asymptote of the species accumulation curve (Fig. 7.4); we did not detect any new species in the last 10 sampling periods. However, for other groups of mammals, the picture is quite different. Based on a comparison of the species we recorded to a list of "possible" species at the park (Appendix I), we believe that we recorded approximately $41 \%$ of the species. Bats make up the bulk of the species we did not find; we recorded only one species and there are a possible 24 additional species (Appendix I). It should be noted, however, that not all of the mammal species would use the building structures or vegetation for any significant amount of time. Most may simply fly over (bats) or pass through (e.g., jaguar) the park en route to habitat elsewhere. Large mammals that we would expect to find include: gray fox, kit fox, mountain lion, and ringtail (Hoffmeister 1986). Hank Cospar, a neighboring landowner, reported shooting a mountain lion on his property in 2000 (pers. comm. to Brian Powell).

\section{Discussion}

A majority of our research on mammals involved trapping small mammals at 25 sites. The high species richness of small mammal communities at the smaller Calabazas and Guevavi units is consistent with known patterns of small mammal species richness in southern Arizona; true semidesert grasslands contain the highest species richness of any vegetation community in southern Arizona (Price 1978, Stamp and Ohmart 1979, Hoffmeister 1986, Sureda and Morrison 1999). Although we did not quantify ground cover at small mammal plots, our plant surveys (particularly modular plot research at the Tumacácori unit) documented high structural diversity (based on percent cover at three height categories), which appears to be important for rodents. We observed, but did not quantify, similar vegetation characteristics at the other two units.

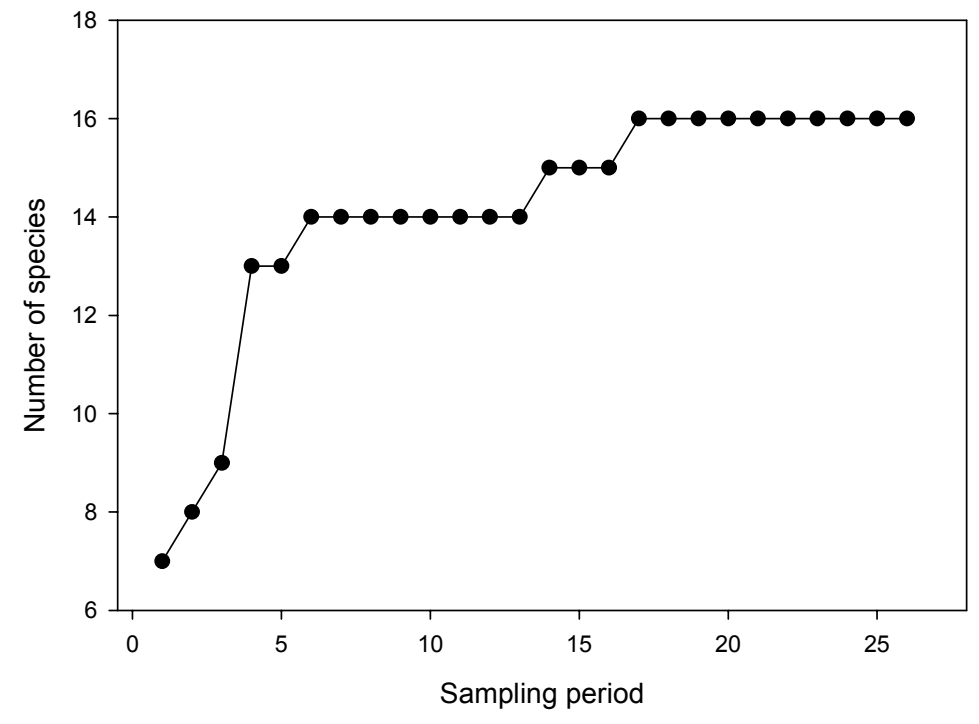

Figure 7.4. Species accumulation curve for small mammal trapping, all park units, Tumacácori NHP, 2000-2001. One sampling period represents one trapping event (2-3 days) at each plot. 


\section{Non-native Species}

The only non-native rodent species that we recorded was the house mouse. It occurred primarily at the Tumacácori unit, not far from buildings (with which it is commonly associated; Hoffmeister 1986). By using Trailmaster photographs and incidental sightings, we documented or observed the nonnative domestic cat, domestic dog, and cow. Domestic cats can pose a serious problem for native vertebrates, especially rodents, reptiles and birds, through harassment and predation of nests and individuals (Clarke and Pacin 2002).

\section{$\underline{\text { Cattle }}$}

Cattle are prohibited from the riparian area around the Tumacácori unit, but trespass livestock is a persistent problem. Cattle are attracted to riparian areas because of an abundance of shade and palatable forage (Kauffman and Krueger 1984), and periodic flooding complicates construction of effective cattle exclosures. Particularly during the record-dry summer of 2002 (Fig. 2.4), the persistence of livestock in the river bottom appears to have contributed to a dramatic decline in understory herbaceous vegetation volume and total vegetation cover (Brian Powell, pers. obs.).

Livestock grazing has degraded an estimated $80 \%$ of streams and riparian ecosystems in the western United States through loss of vegetation, stream-bank erosion, soil compaction, flooding, and water pollution (BLM 1994). Indeed, perhaps no single land use activity has affected western riparian systems as much as cattle grazing (Bahre 1991, Fleischner 1994). Livestock grazing can also increase the number and extent of non-native plants (Belsky et al. 1999) and can negatively affect wildlife through habitat modification and competition for resources (Saab et al. 1995). Nevertheless, it appears that riparian vegetation, and the animals that rely on these rare components, can recover quickly from grazing (Krueper et al. 2003), though recovery from soil erosion and compaction may never be complete.

\section{Virginia Opossum}

We documented the Virginia opossum in $37 \%$ of our infrared photographs at the Tumacácori unit. It is likely that opossums are relatively new to the area (Hoffmeister 1986) and may have several impacts, including predation of bird nests (Peterson et al. 2004), competition with other medium-sized, omnivorous mammals such as the raccoon (Ginger et al. 2003) and transmission of tuberculosis (Mycobacterium bovis) to both wildlife and livestock (Fitzgerald et al. 2003).

\section{Bats}

Our limited field effort (one night) to search for bats produced only one species, the pallid bat. The buildings at the Tumacácori and Calabazas units and persistence of water in the Santa Cruz River and presence of adjacent vegetation certainly host additional species, five of which have been collected from the Tumacácori mission building (Appendix O).

\section{Extirpated Species}

It is important to mention four species that may have occurred at Tumacácori NHP within the last 100 years but which are now extirpated: grizzly bear (Ursus arctos), Mexican gray wolf (Canis lupus baileyi), and bighorn sheep (Ovis canadensis); or is extremely rare: jaguar (Hoffmeister 1986). Among these, the jaguar is the only species that has been seen in proximity to the Tumacácori unit in the last 50 years. The most recent documentation (from a photograph in 2001) is rumored to have been from the Pajarito Mountains (approximately $20 \mathrm{~km}$ southwest of the Calabasas unit), but no location was released to the public. 


\section{Chapter 8: Management Implications}

Based on the data from this study and our knowledge of the natural resource issues at the park, we point out implications that could potentially affect management of the park's natural resources. Coordination with other agencies, non-governmental organizations, and/or adjacent landowners may prove the best route in the future to resolving some of these issues.

\section{Development Adjacent to the Park}

The most serious threat to the biological diversity of Tumacácori NHP is residential development of adjacent and nearby lands. The high value of real estate in the area makes it likely that many of the larger landholders will sell their land to residential real estate developers. Potential impacts of residential development include an increase in the number and extent of non-native plants (see Plant chapter for review of associated concerns), increased runoff of toxins and sediment, disruption of animal movement patterns, habitat loss and fragmentation (Mills et al. 1989, Theobald et al. 1997, Riley et al. 2003), and increased harassment and mortality of native animals by free roaming pets, and feral dogs and cats. Development will also likely increase groundwater withdrawal, possibly reducing the amount of surface water that makes the area biologically rich and valuable. Conservation easements on critical land surrounding the park, which may be most effectively pursued in partnerships with other land-management agencies, non-governmental organizations, and private landowners, could be a valuable tool in helping to maintain the biodiversity of the park.

\section{Natural Resources Staff}

Current staff at Tumacácori NHP includes no natural resources professionals. Thus the monument lacks an efficient means of meeting the inventory, monitoring, assessment, and management needs related to maintaining biodiversity as described in this report. Without new staff the park will likely not effectively (1) manage non-native species, (2) coordinate monitoring activities with Sonoran Desert Network Inventory and Monitoring program, (3) work with adjacent landowners to establish compatible land-use practices, and (4) coordinate research related to other natural resources management issues at the park.

\section{Cattle and Off-road Vehicles}

Cattle and off-road vehicles (ORVs) have a negative impact on the soil, water, and plants of the sensitive riparian area. These impacts can lead to an increase in non-native plant species, mortality of fossorial and slowmoving vertebrate species (e.g., ornate box turtle), increased erosion, and decreased water quality. Cattle and ORVs that are in the riparian area are in trespass and the park staff is currently maintaining fencing in the riparian area.

\section{Managing Invasive, Non-native Species}

There are many non-native plants and animals that pose significant threats to the park's biological and cultural resources. American bullfrog, crayfish, and western mosquitofish should be of particular concern in the Tumacácori channel. A host of terrestrial nonnative species including domestic cats and dogs, cattle (mentioned above), and many nonnative plants, including Bermudagrass, tamarisk, and Russian thistle, thrive in the park. It was beyond the scope of this project to investigate specific control techniques for each species. Many National Park Service units have consulted experts and developed a nonnative species management plan that would guide future management decisions (e.g., NPS 1996). The work by Halvorson and Guertin (2003) would provide an excellent foundation for this process.

\section{Impacts from Undocumented Immigrants}

Undocumented immigrants moving through the park leave behind trash, cut trails, and potentially threaten visitor safety. Border 
Patrol and other law enforcement personnel, in pursuit of undocumented immigrants, may intensify soil compaction, establishment of trails, and other disturbances. Other National Park Service units have successfully worked with Border Patrol and local law-enforcement agencies to maintain visitor safety and resource preservation as priorities in their resources management programs. 


\section{Chapter 9: Additional Inventories}

No inventory is ever truly complete; species' distributions expand and contract across boundaries with time, particularly at small parks such as Tumacácori NHP. In general, we have balanced our efforts between qualitative surveys designed to detect the maximum number of species and quantitative, repeatable surveys designed to estimate relative abundance with an associated measure of precision. Additional inventories could reach the $90 \%$ completion mark for some taxonomic groups.

Future inventory efforts at Tumacácori NHP will benefit from highly skilled and experienced field personnel, and researchers who seek outside expert confirmation of species identifications (with photos or, preferably, voucher specimens) early in the inventory project. We encourage identification and a clear presentation of uncertainties when they occur and openly acknowledge and account for identification problems within genera such as Sigmodon, Cnemidophorus, Sylvilagus, and Bufo (see mammal and amphibian and reptile chapters for details).

\section{Plants}

Additional general botanizing surveys, carried out during wet summers in the expansion area of the Tumacácori unit, should increase the species list for annual plants. A diligent effort to seek out species that have previously been reported (Moatt et al. 1977, Bennett, year unknown) but not found during our surveys, would help confirm possible changes to the flora. Additional modular plots, especially in the under-sampled mesquite bosque and dense cottonwood/willow forests, would be an effective tool for long-term monitoring of vegetation changes.

\section{Amphibians and Reptiles}

Cnemidophorus (whiptail) lizards are difficult to identify; John Wright is an expert who could confirm the identity of specimens from the Tumacácori unit. Confirming whiptails to species would require collection of perhaps 20 individuals to represent various ages and variations in appearance. Whiptails are notoriously difficult to capture; methods that we used with limited success included stunning with large rubber bands, noosing, trapping in pitfall and funnel traps, and capture in blind tubes (PVC pipes capped at one end). We were sometimes able to discover and capture whiptails by "turning cover" (i.e., looking under logs, boards, and debris) during cold mornings. A possible strategy might be to use a hardware cloth net that is chain-weighted along the edges.

Perhaps the two most effective ways to increase the species list for amphibians and reptiles are: 1) take high-quality photographs of animals as they are seen and 2) collect roadkilled animals, particularly snakes, from along the Frontage Road, which borders the Tumacácori unit to the west. Other inventory efforts in Sonoran Desert Network parks have benefited from collection of these indisputable forms of evidence by park staff (Don Swann, pers. comm.). The Sonoran Desert Network staff can facilitate accession of collected specimens.

\section{Birds}

Additional surveys during the winter and late summer/early fall migration will add species missed by our efforts. It is important to note, however, that bird lists are difficult to complete, particularly for very rare species in the area (e.g., northern parula, gray catbird, and worm-eating warbler; Appendix D). Only sites that are visited regularly by avid bird watchers (e.g., Madera Canyon, Ramsey Canyon, and Sonoita Creek Preserve in southern Arizona) have bird lists that can be considered to be largely "complete."

The riparian area at the Tumacácori unit is becoming an increasingly popular destination for bird watchers. This increased attention is due to a number of factors including presence 
of the Monitoring Avian Productivity and Survivorship station and the designation of the area as an "Important Bird Area" by the Tucson Audubon Society.

\section{Southwestern Willow Flycatcher Surveys}

Additional surveys, conducted by trained observers in cooperation with Arizona Game and Fish Dept, can confirm the status of the southwestern willow flycatcher at Tumacácori NHP. Such surveys are beyond the ability of current park personnel.

\section{Mammals}

Additional bat surveys would be useful, particularly mist-netting along the Santa Cruz River and periodic checking of the structures for roosting bats because it is possible to observe presence of additional species using these simple methods. The use of ultrasonic detectors to identify bat species is increasing and many researchers are refining the field techniques and improving the technology (e.g., Johnson et al. 2002, Gannon et al. 2003).

These technologies may become more helpful in the coming years with these refinements.

Additional infrared-triggered camera work can document the presence of medium and large terrestrial mammals, and a number of species will inevitably be documented with further surveys (e.g., mountain lion). Care must be taken in placing the units because of the potential for cameras to be damaged or stolen.

\section{Effects of Water Quality on Wildlife}

Water quality of the Santa Cruz River is currently being monitored because most of the perennial flow in the river comes from the Nogales Wastewater Treatment Plant. Better information is needed on the effects that the chemicals left in the water following treatment have on the vertebrates in the river (King et al. 1999). Currently, residual pharmaceuticals are not being tested for and potentially may be affecting river dwelling species in the park. 


\section{Chapter 10: Glossary}

Abundance: Number of individuals (or groups, clusters), expressed in relative or absolute terms.

Accuracy: Closeness of a measured value to the true value (see precision).

Community species richness: Number of species in a grouping, which may be delineated at various scales and perspectives (e.g., functional, geographic, taxonomic). True richness is seldom known and in this report we present recorded richness.

Density: Number of individuals scaled by unit of area or volume (e.g., four chipping sparrows/hectare).

Documented: Species was verified by evidence: voucher specimen (or parts of a specimen) or photograph (see observed and recorded).

Ecological community: A collection of populations in a defined (spatial and temporal) location (e.g., amphibians at Tumacácori NHP).

Ecological population: A group of individuals of the same species in a defined location (e.g., cottonwood trees at Tumacácori NHP).

Habitat: A species-specific term that generally refers to an area with resources and environmental conditions to promote occupancy, survival, and reproduction of that species (Morrison et al. 1998; see Chapter 1).

$\underline{n}$ : Sample size; number of sample units.

Neotropical migrants: bird species that include populations breeding north and wintering south of the Tropic of Cancer (Rappole 1995).

Observed: Species or individual seen and/or heard by a reliable observer (see documented and recorded).

Precision: Closeness of repeated measurement to each other (see accuracy).
Recorded: Species or individual observed and/or documented (see observed and documented).

Relative abundance: An index to abundance, usually the number of individuals (groups, clusters) recorded in a survey, scaled by survey effort (e.g., five gopher snakes per person-hour) and presented as a mean of all surveys, with an estimate of precision (e.g., standard error)

Standard error (SE): The standard deviation of a mean divided by the square of $n$; a measure of the precision of an estimate (e.g., sample mean).

Standard deviation: The square root of variance, which is the average of squared deviations from the mean. Deviation from mean is the difference between individual samples and the mean of all samples. 


\section{Chapter 11: Literature Cited}

American Ornithologists' Union (AOU). 1998. Checklist of North American birds, seventh edition. American Ornithologists' Union and Allen Press Inc., Lawrence, KS.

American Ornithologists' Union (AOU). 2003. Forty-second supplement to the American Ornithologists' Union checklist of North American birds. Auk 117:847858.

Arizona Department of Environmental Quality (ADEQ). 2000. The status of water quality in Arizona Clean Water Act section 305(b) Report 2000. EQR-00-03. Phoenix, AZ.

Arizona Department of Water Resources (ADWR). 1999. Third management plan for the Phoenix Active Management Area, 2000-2010. Phoenix, AZ.

Arizona Game and Fish Department (AZGF). 1995. Poeciliopsis occidentalis occidentalis. Unpublished abstract compiled and edited by the Heritage Data Management System, Arizona Game \& Fish Department, Phoenix, AZ.

Arizona Game and Fish Department (AZGF). 2004. Accessed 5 March February 2004 from :

www.gf.state.az.us/w_c/edits/hdms_status _definitions.html.

Arizona Poison and Drug Information Center (APDIC). 2003. Accessed 20 February 2003 from APDIC website: http://www.pharmacy.arizona.edu/centers /apdic/snakes.shtml.

Arnold, L. W. 1940. An ecological study of the vertebrate animals of the mesquite forest. MS thesis, University of Arizona, Tucson, AZ.

Averill-Murray, A., S. Lynn, and M. L. Morrison. 1999. Cowbird parasitism of Arizona Bell's vireos (Vireo bellii arizonae) in a desert riparian landscape: implications for cowbird management and riparian restoration. Studies in Avian Biology 18:109-120.
Baker, R. J., L. C. Bradley, R. D. Bradley, J. W. Dragoo, M. D. Engstrom, R. S. Hoffmann, C. A. Jones, F. Reid, D. W. Rice, and C. Jones. 2003. Revised checklist of North American mammals north of Mexico, 2003. Occasional Papers of the Museum of Texas Tech University 229:1-23.

Beauvais, G. P. and S. W. Buskirk. 1999. Modifying estimates of sampling effort to account for sprung traps. Wildlife Society Bulletin 27:39-43.

Bahre, C. J. 1991. A legacy of change: historic human impact on vegetation of the Arizona borderlands. University of Arizona Press, Tucson, AZ.

Bednarz, J. C. and R. J. Raitt. 2002. Chihuahuan raven (Corvus cryptoleucus). In The birds of North America, No. 606. A. Poole and F. Gill, eds. The Birds of North America, Inc., Philadelphia, PA.

Belsky, A. J., A. Matzke, and S. Uselman. 1999. Survey of livestock influences on stream and riparian ecosystems in the western United States. Journal of Soil and Water Conservation 54:419-431.

Bennett, P. Year unknown. Reference list. (A list of plants of Tumacácori National Historic Park; obtained in 1999). Unpublished; created while an employee of the US Geological Survey, Biological Resources Division, Sonoran Desert Research Station, University of Arizona, Tucson, AZ.

Bestgen, K. R., D. A. Hendrickson, D. M. Kubly, and D. L. Propst. 1987. Movement and growth of fishes in the Gila River drainage, Arizona and New Mexico. Southwestern Naturalist 32:351356.

Bibby, C. J., N. D. Burgess, and D. A. Hill. 2000. Bird census techniques. Academic Press, London, England.

Bock, C. E., J. H. Bock, K. L. Jepson, and J. C. Ortega. 1986. Ecological effects of planting African lovegrasses in Arizona. 
National Geographic Research 2:456463.

Braun-Blanquet, J. 1965. Plant sociology: the study of plant communities. Hafner Inc., London, England.

Brooks, M. L. and D. A. Pyke. 2001. Invasive plants and fire in the deserts of North America. Tall Timbers Research Station Miscellaneous Publication 11:1-14.

Brotons, L. and S. Herrando. 2001. Reduced bird occurrence in pine forest fragments associated with road proximity in a Mediterranean agricultural area. Landscape and Urban Planning 57:77-89.

Brown, D. E. and C. H. Lowe. 1980. Biotic communities of the Southwest: supplementary map to biotic communities: southwestern United States and northwestern Mexico. D. Brown, editor. University of Utah Press, Salt Lake City, UT.

Brown, D. E., C. H. Lowe, and C. P. Pase. 1979. A digitized classification system for the biotic communities of North America, with community (series) and association examples for the southwest. Journal of Arizona-Nevada Academy of Science 14:1-16.

Buckland, S. T., D. R. Anderson, K. P. Burnham, and J. L. Laake. 1993. Distance sampling: estimating abundance of biological populations. Chapman and Hall, New York, NY.

Bureau of Land Management (BLM). 1994. Rangeland reform 1994. Draft environmental impact statement. U. S. Department of the Interior, Washington, D.C.

Burt, W. H. and R. P. Grossenheider. 1976. The Peterson field guide series: a field guide to the mammals of North America north of Mexico. Houghton Mifflin, New York, NY.

California Department of Food and Agriculture (CDFA). 2004. Encycloweedia: notes on identification, biology, and management of plants defined as noxious weeds by California law. Accessed 10 February
2004 from:

http://pi.cdfa.ca.gov/weedinfo/Index.html.

Chaney, E., W. Elmore, and W. S. Platts. 1990. Livestock grazing on western riparian areas. Northwest Resource Information Center Inc., Eagle, ID.

Clarke A. L. and T. Pacin. 2002. Domestic cat "colonies" in natural areas: a growing exotic species threat. Natural Areas Journal 22:154-159.

Colver, K. J., D. Stokes, and L. Stokes. 1999. Stokes field guide to bird songs. Time Warner, New York, NY.

Corn, S. P. 1994. Straight-line drift fences and pitfall traps. Pp. 109-117. In W. R. Heyer, M. A. Donnelly, R. W. McDiarmid, L. C. Hayek, and M. S. Foster, eds. Measuring and monitoring biodiversity: standard methods for amphibians. Smithsonian Institution Press, Washington, D.C.

Courtenay, W. R., Jr., and G. K. Meffe. 1989. Small fishes in strange places: a review of introduced poeciliids. Pp. 319-331. In G. K. Meffe and F. F. Snelson, Jr., eds. Ecology and evolution of livebearing fishes (Poeciliidae). Prentice Hall, Engelwood Cliffs, NJ.

Creed, R. P. 1994. Direct and indirect effects of crayfish grazing in a stream community. Ecology 75:2091-2103.

Crump, M. L., and N. J. Scott. 1994. Visual encounter surveys. Pp. 84-92. In W. R. Heyer, M. A. Donnelly, R. W. McDiarmid, L. C. Hayek, and M. S. Foster, eds. Measuring and monitoring biodiversity: standard methods for amphibians. Smithsonian Institution Press, Washington, D.C.

Cutler, T. L., and D. E. Swann. 1999. Using remote photography in wildlife ecology: a review. Wildlife Society Bulletin 27:571-581.

D'Antonio, C. M., and P. M. Vitousek. 1992. Biological invasions by exotic grasses, the grass fire cycle, and global change. Annual Review of Ecology and Systematics 23:63-87. 
Daubenmire, R. 1976. The use of vegetation in assessing the productivity of forest lands. Botanical Review 42:115-43.

Dauble, D. D. and R. H. Gray. 1980. Comparison of a small seine and a backpack electroshocker to evaluate nearshore fish population in rivers. The Progressive Fish-Culturist 42:93-95.

Davis, K. and W. L. Halvorson. 2000. A study plan to inventory vascular plants and vertebrates: Sonoran Desert Network. National Park Service, Phoenix, AZ.

Davis, W. A. and S. M. Russell. 1999. Finding birds in southeast Arizona. Tucson Audubon Society, Tucson, AZ.

Degenhardt, W. G., C. W. Painter, and A. H. Price. 1996. Amphibians and reptiles of New Mexico. University of New Mexico Press, Albuquerque, NM.

DeSante, D. F., K. M. Burton, J. F. Saracco, and B. L. Walker. 1995. Productivity indices and survival rate estimates from MAPS, a continent-wide programme of constant-effort mist netting in North America. Journal of Applied Statistics 22:935-947.

Drake, S., H. Rodriquez-Gallegos, A. Hubbard, and S. Skirvin. 2003. Comparative analysis of remote sensing techniques for vegetation mapping and monitoring on Sonoran Desert Network parks. Report to the Sonoran Desert Network Inventory and Monitoring program, National Park Service, Tucson, AZ.

Drost, C. A. 1998. Survey of amphibians and amphibian habitat on the upper Santa Cruz River, Arizona. Unpublished report to the U.S. Bureau of Reclamation.

Ehrlich, P. R., D. S. Dobkin, and D. Wheye. 1988. The birder's handbook: a field guide to the natural history of North American birds. Simon and Shuster, New York, NY.

Fellers, G. M. and C. A. Drost. 1994. Sampling with artificial cover. Pp. 146150. In W. R. Heyer, M. A. Donnelly, R.
W. McDiarmid, L. C. Hayek, and M. S. Foster, eds. Measuring and monitoring biodiversity: standard methods for amphibians. Smithsonian Institution Press, Washington, D.C.

Felger, R. S. 1990. Non-native plants of Organ Pipe Cactus National Monument, Arizona. Technical Report No. 31. Cooperative National Park Resource Studies Unit, University of Arizona, Tucson, AZ.

Felger R. S. and M. F. Wilson. 1995. Northern Sierra Madre Occidental and its Apachian outliers: a neglected center of biodiversity. In L. F. Debano, P. F. Ffolliott, A. Ortega-Rubio, G. Alfredo, G. J. Gottfried, R. H. Hamre, and C. B. Edminster, technical coordinators. 1995. Biodiversity and management of the Madrean Archipelago: the sky islands of southwestern United States and northwestern Mexico. 19-23 Sept 1994.; Tucson, AZ. Gen. Tech. Rep. RM-GTR264. U.S. Department of Agriculture, Forest Service, Rocky Mountain Forest and Range Experiment Station, Fort Collins, CO.

Fernandez, P. J. and P. C. Rosen. 1996. Final report: effects of the introduced crayfish Orconectes virilis on native aquatic herpetofauna in Arizona. Submitted to Arizona Game and Fish Department, Heritage Fund, Phoenix, AZ.

Fitzgerald, S. D., L. S. Zwick, K. L. Diegel, D. E. Berry, S. V. Church, J. G. Sikarskie, J. B. Kaneene, and W. M. Reed. 2003. Experimental aerosol inoculation of Mycobacterium bovis in North American opossums (Didelphis virginiana). Journal of Wildlife Diseases 39:418-423.

Fleischner, T. L. 1994. Ecological costs of livestock grazing in western North America. Conservation Biology 8:629644.

Fuller, M. R. and J. A. Mosher. 1987. Raptor survey techniques. Pp. 37-66. In B. A. Geron-Pendleton, B. A. Millsap, K. W. Cline, and D. M. Bird, eds. Raptor 
management techniques manual. National Wildlife Federation, Washington, D.C.

Gannon, W. L., R. E. Sherwin, and S.

Haymond. 2003. On the importance of

articulating assumptions when conducting acoustic studies of habitat use by bats.

Wildlife Society Bulletin 31:45-61.

Gibbons, J. M. and R. D. Semlitsch. 1981.

Terrestrial drift fence with pitfall traps: an effective technique for quantitative sampling of animal populations.

Brimleyana 7:1-6.

Ginger, S. M., E. C. Hellgren, M. A. Kasparian, L. P. Levesque, D. M. Engle and D. M. Leslie. 2003. Niche shift by Virginia opossum following reduction of a putatice competitor, the raccoon. Journal of Mammalogy 84:1279-1291.

Halvorson, W. L. and P. Guertin. 2003. USGS Weeds in the West project: status of introduced plants in southern Arizona Parks. U.S. Geological Survey, Southwest Biological Science Center, Sonoran Desert Research Station, University of Arizona, Tucson, AZ.

Hatten, J. R. and C. E. Paradzick. 2003. A multiscaled model of southwestern willow flycatcher breeding habitat. Journal of Wildlife Management 67:774-788.

Hayek, L. C. and M. A. Buzas. 1997.

Surveying natural populations. Columbia University Press, New York, NY.

Hayes, M. P. and M. R. Jennings. 1986. Decline of Ranid frog species in western North America: are bullfrogs (Rana catesbeiana) responsible? Journal of Herpetology 20:490-509.

Heilbrun, R. D., N. J. Silvy, M. E. Tewes, and M. J. Peterson. 2003. Using automatically triggered cameras to identify individual bobcats. Wildlife Society Bulletin 31:748-755.

Heritage Data Management System (HDMS). 2004. Arizona Game and Fish Department. Accessed 5 March from: http://www.gf.state.az.us/w_c/edits/hdms _species_lists.html.
Hoffmeister, D. F. 1986. Mammals of Arizona. The University of Arizona Press, Tucson, AZ.

Holdich, D. M. and R. S. Lowery. 1988. Freshwater crayfish: biology, management, and exploitation. Timber Press, Portland, OR.

Hughes, J. M. 1999. Yellow-billed cuckoo. In Birds of North America: Life histories for the $21^{\text {st }}$ century. A. Poole and F. Gill, eds. The birds of North America, Inc., Philadelphia, PA.

Integrated Taxonomic Information System (ITIS). 2004. Accessed on 20 March 2004. http://www.itis.usda.gov/index.html.

Ivanyi, C., J. Perry, T. R. Van Devender, and H. Lawler. 2000. Reptile and amphibian accounts. Pp. 533-585. In S. J. Phillips and P. W. Comus, eds. A natural history of the Sonoran Desert. Arizona-Sonora Desert Museum Press, Tucson, AZ.

Johnson, C. W. and J. P. Smith. 1983. Soil loss caused by off-road vehicle use on steep slopes. Transactions of the American Society of Agricultural Engineers 26:402-411.

Johnson, J. B., M. A. Menzel, J. W. Edwards, and W. M. Ford. 2002. A comparison of 2 acoustical bat survey techniques. Wildlife Society Bulletin 30:931-936.

Karpiscak, M. M., C. P. Gerba, P. M. Watt, K. E. Foster, and J. A. Falabi. 1996. Multispecies plant systems for wastewater quality improvements and habitat enhancement. Water Science and Technology 33:231-236.

Karpiscak, M. M., L. R. Whiteaker, J. F. Artiola, and K. E. Foster. 2001. Nutrient and heavy metal uptake and storage in constructed wetland systems in Arizona. Water Science and Technology 44:455462.

Kauffman, J. B. and W. C. Krueger. 1984. Livestock impacts on riparian ecosystems and streamside management implications: a review. Journal of Range Management $37: 430-438$. 
Kiesecker, J. M. and A. R. Blaustein. 1997. Population differences in responses of red-legged frogs (Rana aurora) to introduced bullfrogs. Ecology 78:17521760.

King, K. A., B. J. Zaun, and A. L. Velasco. 1999. Contaminants as a limiting factor of fish and wildlife populations in the Santa Cruz River, Arizona. United States Fish and Wildlife Service Region 2 Contaminants Program, Phoenix, AZ.

Knopf, F. L. and F. B. Samson. 1994. Scale perspectives on avian diversity in western riparian ecosystems. Conservation Biology 8:669-676.

Krebs, C. J. 1998. Ecological Methodology. Second Edition. Addison-Welsey Educational, Menlo Park, CA.

Kubly, D. 1997. Introduced crayfish in Arizona: a nuisance in our waters. Arizona Wildlife Views 40:14-15.

Kucera, T. E. and R. H. Barrett. 1993. The Trailmaster camera system for detecting wildlife. Wildlife Society Bulletin 21:505-508.

Krueper, D., J. Bart, and T. D. Rich. 2003. Response of vegetation and breeding birds to the removal of cattle on the San Pedro River, Arizona (U.S.A.). Conservation Biology 17:607-615.

Lancia, R. A., J. D. Nichols, and K. H. Pollock. 1996. Estimating the number of animals in wildlife populations. Pp. 215253. In T. A. Bookhout, editor. Research and management techniques for wildlife and habitats. Fifth edition. The Wildlife Society, Bethesda, MD.

Latta, M. J., C. J. Beardmore, and T. E. Corman. 1999. Arizona Partners in Flight conservation plan. Technical Report 142. Nongame and Endangered Wildlife Program, Arizona Game and Fish Department, Phoenix, AZ.

Lawler, S. P., D. Dritz., T. Strange, and M. Holyoak. 1999. Effects of introduced mosquitofish and bullfrogs on the threatened California red-legged frog. Conservation Biology 13:613-622.
Laymon, S. A. and M. D. Halterman. 1987. Can the western subspecies of the yellowbilled cuckoo be saved from extinction? Western Birds 18:19-25.

Lee, L. C., T. A. Muir, and R. R. Johnson. 1989. Riparian ecosystems as essential habitat for raptors in the American West. Pp. 15-26. In B. G. Pendleton, editor. Western raptor management symposium and workshop. National Wildlife Federation, Washington, D.C.

MacArthur, R. H. and J. W. MacArthur. 1961. On bird species diversity. Ecology 42:594-598.

McIntyre, D. L. and J. R. Weeks. 2002. Environmental impacts of illegal immigration on the Cleveland National Forest in California. The Professional Geographer 54:392-405.

McLaughlin, S. P., E. L. Geiger, and J. E. Bowers. 2001. Flora of the AppletonWhittell Research Ranch, Northeastern Santa Cruz County, Arizona. Journal of the Arizona-Nevada Academy of Science 33:113-131.

McGarigal, K., S. Cushman, and S. Stafford. 2000. Multivariate statistics for wildlife and ecology research. Springer-Verlag, New York, NY.

Marsh, P. C. and W. L. Minckley. 1990. Management of endangered Sonoran topminnow at Bylas Springs, Arizona: description, critique, and recommendations. Great Basin Naturalist 50:265-272.

Meffe, G. K. 1985. Predation and species replacement in southwestern fishes: a case study. Southwestern Naturalist 30:173187.

Meffe, G. K., D. A. Hendrickson, W. L. Minckley, and J. N. Rinne. 1983. Factors resulting in decline of the endangered Sonoran topminnow (Antheriniformes: Poeciliidae) in the United States. Biological Conservation 25:135-159.

Mehlman. D. W. 1995. Notes on the increase of the brown-headed cowbird in New Mexico. Western Birds 23:59-63. 
Miller, R. R. 1961. Man and the changing fish fauna of the American Southwest. Papers of the Michigan Academy of Sciences, Arts and Letters 45:365-404.

Mills, G. S., J. B. Dunning Jr., and J. M. Bates. 1989. Effects of urbanization of breeding bird community structure in southwestern desert habitats. Condor 91:416-428.

Minckley, W. L. 1973. Fishes of Arizona. Arizona Game and Fish Department, Phoenix, AZ.

Minckley, W. L. 1999. Ecological review and management recommendations for recovery of the endangered Gila topminnow. Great Basin Naturalist 59:230-244.

Minckley, W. L. and J. E. Deacon, eds. 1991. Battle against extinction: native fish management in the American West. University of Arizona Press, Tucson, AZ.

Morrison, M. L., B. G. Marcot, and R. W. Mannan. 1998. Wildlife-habitat relationships: concepts and applications. Second Edition. University of Wisconsin Press, Madison, WI.

Mouat, D. A., S. J. Walker, and B. D. Treadwell. 1977. The Tumacácori Mission National Monument floral inventory and vegetation map project. Office of Arid Lands Studies, Applied Remote Sensing Program, University of Arizona, Tucson, AZ.

Naeem, S., L. J. Thompson, T. H. Jones, J. H. Lawton, S. P. Lawler, and R. M. Woodfin. 1996. Changing community composition and elevated $\mathrm{CO}_{2}$. Pp. 93100. In C. Korner, and F. A. Bazzaz, eds. Carbon Dioxide, Populations, and Communities. Academic Press, San Diego, CA.

National Park Service (NPS). 1992. NPS-75: Natural resources inventory and monitoring guidelines. U.S. Dept. of Interior, National Park Service, Washington, D.C.

National Park Service (NPS). 1993. Draft general management plan and environmental impact statement,
Tumacácori National Historical Park, Arizona. U.S. Dept. of Interior, National Park Service, Washington, D.C.

National Park Service (NPS). 1996. General management plan and environmental impact statement: Tumacácori National Historical Park. U.S. Dept. of Interior, National Park Service, Washington, D.C.

National Parks Service (NPS). 2001. Baseline water quality data inventory and analysis (BWQDIA), Tumacácori National Historical Park. U.S. Dept. of Interior, Water Resources Division and Servicewide Inventory and Monitoring Program, Fort Collins, CO.

National Park Service (NPS). 2003. Resource issues in southern U.S. border parks from drug trafficking and undocumented alien activity. Unpublished report, April 2003. Southern Arizona Office, National Park Service, Phoenix, AZ.

Nelson, L. and F. W. Clark. 1973. Correction for sprung traps in catch/effort calculations of trapping results. Journal of Mammology 54:295-298.

North American Ornithological Atlas Committee (NAOAC). 1990. Handbook for atlasing North American breeding birds. C. Smith, editor. Accessed 13 July 2001 from: http://americanbirding.org/norac/atlascont.h tm.

O'Dell, D. 2003. Effects of trampling on small mammal, bird, and vegetation communities. Unpublished M.S. thesis proposal. School of Natural Resources, University of Arizona, Tucson, AZ.

Ohmart, R. D. 1994. The effects of humaninduced changes on the avifauna of western riparian habitats. Studies in Avian Biology 15:272-285.

Office of Technology Assessment (OTA). 1993. Harmful non-indigenous species in the United States. OTA-F-565, U.S. Government Printing Office, Washington, D.C.

Osborne, L. L. and D. A. Kovacic. 1993. Riparian vegetated buffer strips in water- 
quality restoration and stream management. Freshwater Biology 29:243-258.

Peet, R. K., T. R. Wentworth, and P. S. White. 1998. A flexible, multipurpose method for recording vegetation composition and structure. Castanea 63:262-274.

Peterson, B. L., B. E. Kus, and D. H. Deutschman. 2004. Determining nest predators of the least Bell's vireo through point counts, tracking stations and video photography. Journal of Field Ornithology 75:89-95.

Powell, B. F. 2000. Results of yellow-billed cuckoo surveys adjacent to Tumacácori National Historical Park in Arizona: a report on the 2000 breeding season. U.S. Geological Survey, Sonoran Desert Research Station, University of Arizona, Tucson, AZ.

Powell, B. F. and R. J. Steidl. 2000. Nesting habitat and reproductive success of southwestern riparian birds. Condor 102:823-831.

Powell, B. F., E. W. Albrecht, W. L. Halvorson, C. A. Schmidt, P. Anning, and K. Docherty. 2004. Vascular plant and vertebrate inventory of Tumacácori National Historical Park. Final report to the National Park Service, Sonoran Desert Inventory and Monitoring Program, Tucson, AZ.

Powell, B. F., E. W. Albrecht, W. L. Halvorson, and K. Docherty. 2003. Biological inventory report for the Sonoran Desert Network: 2002. Annual Report No. 2. Sonoran Desert Network Inventory Program. U.S. Geological Survey, Sonoran Desert Research Station and School of Renewable Natural Resources, University of Arizona, Tucson, AZ.

Powell, B. F., K. Docherty, and W. L. Halvorson. 2002. Biological inventory report for the Sonoran Desert Network: 2000 and 2001 field seasons. Annual Report No. 1. Sonoran Desert Network Inventory Program. U.S. Geological Survey, Sonoran Desert Research Station and School of Renewable Natural Resources, University of Arizona, Tucson, AZ.

Price, M. V. 1978. The role of microhabitat in structuring desert rodent communities. Ecology 59:10-921.

Ralph, C. J., J. R. Sauer, S. Droege, technical eds. 1995. Monitoring bird populations by point counts. Gen. Tech. Rep. PSWGTR-149. Pacific Southwest Research Station, Forest Service, U.S. Department of Agriculture, Albany, CA.

Rappole, J. H. 1995. The ecology of migrant birds: a neotropical perspective.

Smithsonian Institution Press, Washington, D.C.

Recon. 2004. Advance draft, Pima County multiple species conservation plan, Pima County, Arizona. Recon report number 3273B.

Reynolds, R. T., J. M. Scott, and R. A. Nussbaum. 1980. A variable circularplot method for estimating bird numbers. Condor 82:309-313.

Rice, J., B. W. Anderson, and R. D. Ohmart. 1984. Comparison of the importance of different habitat attributes to avian community organization. Journal of Wildlife Management 48:895-911.

Riley, S. P. D., R. M. Sauvajot, T. K. Fuller, E. C. York, D. A. Kamradt, C. Bromley, and R. K. Wayne. 2003. Effects of urbanization and habitat fragmentation on bobcats and coyotes in southern California. Conservation Biology 17:566-576.

Robins, C. R. 1991. Common and scientific names of fishes from the United States and Canada. Fifth edition. American Fisheries Society Special Publication 20. American Fisheries Society, Bethesda, MD.

Rosen, P. C. 2000. A monitoring study of vertebrate community ecology in the northern Sonoran Desert, Arizona. Unpublished $\mathrm{PhD}$ dissertation, Department of Ecology and Evolutionary 
Biology, University of Arizona, Tucson, AZ.

Rosen, P. C. and K. Mauz. 2001. Biological values of the West Branch of the Santa Cruz River, with an outline for a potential reserve; including a preliminary flora. Document for the Sonoran Desert Conservation Plan, Pima County Board of Supervisors, Tucson, AZ. Accessed 4 April 2004:

http://www.co.pima.az.us/cmo/sdcp/sdcp2 /reports/WB/WestBF.htm\#_Toc52410838 4

Rosen, P. C., B. Radke, and D. J. Caldwell. 2004. Lowland riparian herpetofaunas in Southeastern Arizona. In Biodiversity and management of the Madrean Archipelago II: Connecting mountain islands and desert seas. General Technical Report. In prep. U.S. Department of Agriculture, Forest Service, Fort Collins, CO.

Rosen, P. C., C. R. Schwalbe, D. A. Parizek, Jr., P. A. Holm, and C. H. Lowe. 1995. Introduced aquatic vertebrates in the Chiricahua region: effects on declining native ranid frogs. Pp. 251-261. In biodiversity and management of the Madrean Archipelago: the sky island of the southwestern United States and northwestern Mexico. General Technical Report RM-GTR-264. U.S. Department of Agriculture, Forest Service, Rocky Mountain Research Station, Fort Collins, CO.

Rosenberg, K. V., R. D. Ohmart, W. C. Hunter, and B. W. Anderson. 1991. Birds of the lower Colorado River Valley. University of Arizona Press, Tucson, AZ.

Rothstein, S. I. 1994. The cowbird's invasion of the far west: history, causes, and consequences experienced by host species. Pp. 301-315. In J. R. Jehl, Jr. and N. K. Johnson, eds. A century of avifaunal change in western North America. Studies in Avian Biology No. 15.
Russell, S. M. and G. Monson. 1998. The birds of Sonora. University of Arizona Press, Tucson, AZ.

Schwalbe, C. R. and P. C. Rosen. 1988. Preliminary report on effects of bullfrogs on wetland herpetofauna in southeastern Arizona. Pp. 166-173. In R. C. Szaro, K. E. Severson, and D. R. Patton, eds. Management of amphibians, reptiles, and small mammals in North America. Gen. Tech. Rep. RM-166, U.S. Department of Agriculture, Forest Service, Rocky Mountain Research Station, Fort Collins, $\mathrm{CO}$.

Schweitzer, S. H., D. M. Finch, and D. M. Leslie, Jr. 1998. The brown-headed cowbird and its riparian dependant hosts in New Mexico. General Technical Report RMRS-GTR-1. U.S. Department of Agriculture, Forest Service, Rocky Mountain Research Station, Fort Collins, $\mathrm{CO}$.

Saab, V. A., C. E. Bock, T. D. Rich and D. S. Dobkin. 1995. Livestock grazing effects in western North America. Pp. 311-353. In T. E. Martin and D. M. Finch, eds. Ecology and management of neotropical migratory birds: a synthesis and review of critical issues. Oxford University Press, London, England.

Skagen, S. K., C. P. Melcher, W. H. Howe, and F. L. Knopf. 1998. Comparative use of riparian corridors and oases by migrating birds in southeastern Arizona. Conservation Biology 12:896-909.

Smith, J. N. M., M. J. Taitt, and L. Zanette. 2002. Removing brown-headed cowbirds increases seasonal fecundity and population growth in song sparrows. Ecology 83:3037-3047.

Southwell, C. 1996. Estimation of population size and density when counts are incomplete. In D. E. Wilson, F. R. Cole, J. D. Nichols, R. Rudran, and M. S. Foster, eds. Measuring and monitoring biological diversity: standard methods for mammals. Smithsonian Institution Press, Washington, D.C. 
Sprouse, T., R. Emanuel, B. Tellman. 2002.

Final report: Surface water quality monitoring overview and assessment for the Sonoran Desert Network, National Park Service. Unpublished report. Water Resources Research Center, University of Arizona, Tucson, AZ.

Stamp, N. E. and R. D. Ohmart. 1979. Rodents of desert shrub and riparian woodland habitats of the Sonoran desert. Southwestern Naturalist 24:279-289.

Stebbins, R. C. 2003. A field guide to western reptiles and amphibians. Third edition. Houghton Mifflin, New York, NY.

Stohlgren, T. J., J. F. Quinn, M. Ruggiero, and G. S. Waggoner. 1995. Status of biotic inventories in U.S. national parks. Biological Conservation 71:97-106.

Strong, T. R. and C. E. Bock. 1990. Bird species distribution in riparian habitats in southeastern Arizona. Condor 92:866885.

Sullivan, B. K., R. W. Bowker, K. B. Malmos, and E. W. A. Gergus. 1996. Arizona distribution of three Sonoran Desert anurans: Bufo retiformis, Gastrophryne olivacea, and Pternohyla fodiens. Great Basin Naturalist 56:38-47.

Sureda, M. and M. L. Morrison. 1999. Habitat characteristics of small mammals in southeastern Utah. Great Basin Naturalist 59:323-330.

Swann, D. E., C. C. Hass, D. C. Dalton, and S. A. Wolf. 2004. Infrared-triggered cameras for detecting wildlife: an evaluation and review. Wildlife Society Bulletin 32:1-9.

Theobald, D. M., J. R. Miller, and N. T. Hobbs. 1997. Estimating the cumulative effects of development on wildlife habitat. Landscape and Urban Planning 39:25-36.

Thomas, J. W., C. Maser, and J. E. Rodiek. 1979. Wildlife habitats in managed rangelands, the Great Basin of southeastern Oregon: riparian zones. General Technical Report PNW-80. U.S. Department of Agriculture, Forest Service, Arcata, CA.
Thompson, S. K. 1992. Sampling. John Wiley and Sons, New York, NY.

Turner, W. 2003. Bird banding at Tumacácori National Historical Park, AZ Draft. Unpublished report to the National Park Service, Phoenix, AZ.

United States Department of Agriculture (USDA). 2004. The PLANTS Database, Version 3.5 National Plant Data Center, Natural Resources Conservation Service, Baton Rouge, LA. Accessed 1 February 2004: (http://plants.usda.gov).

United States Environmental Protection Agency. 2001. National primary drinking water standards. EPA 816-F-01007.

United States Fish and Wildlife Service (USFWS). 2002. Birds of conservation concern 2002. Division of migratory bird management, Arlington, VA.

VanHorne, B. 1983. Density as a misleading indicator of habitat quality. Journal of Wildlife Management 47:893-901.

Voeltz, J. B. and R. H. Bettaso. 2003. 2003 Status of the Gila topminnow and desert pupfish in Arizona. Nongame and Endangered Wildlife Program Technical Report 226. Arizona Game and Fish Department, Phoenix, AZ.

Verner, J. and L. V. Ritter. 1983. A comparison of transects and point counts in oak-pine woodlands of California. Condor 87:47-68.

Weedman, D. A. and K. L. Young. 1987. Status of the Gila topminnow and desert pupfish in Arizona. Nongame and Endangered Wildlife Program Technical Report 118. Arizona Game and Fish Department, Phoenix, AZ.

Weedman, D. A., A. L. Girmendonk, and K. L. Young. 1996. Status review of Gila chub, Gila intermedia, in the United States and Mexico. Nongame and Endangered Wildlife Program Technical Report 91. Arizona Game and Fish Department, Phoenix, AZ.

Weedman, D. A. 1998. Gila topminnow, Poeciliopsis occidentalis occidentalis, 
revised recovery plan. Arizona Game and Fish Department, Phoenix, AZ. Prepared for U.S. Fish and Wildlife Service, Albuquerque, NM.

Western Regional Climate Center (WRCC). 2004. Arizona Climate Sumaries from Tumacácori National Historical Park: Accessed 1 March 2004:

http://www.wrcc.dri.edu/summary/clims maz.html.

White, G. C., K. P. Anderson, K. P. Burnham, and D. L. Otis. 1983. Capture-recapture and removal methods for sampling closed populations. Los Alamos National Laboratory, Los Alamos, NM.

Wilshire, H. G. 1983. Off-road vehicle recreation management policy for public lands in the United States: a case history. Environmental Management 7:489-500.

Wright, J. W. 1993. Evolution of the lizards in the genus Cnemidophorus. Pp. 27-81. In P. R. Brown and J. W. Wright, eds. Biology of whiptail lizards (genus Cnemidophorus). Oklahoma Museum of Natural History, Norman, OK. 
Appendix A. List of plant species that were observed (0) or documented (D) at Tumacácori NHP by University of Arizona Inventory personnel, 2000-2003. Species in bold-faced type are non-native. Species denoted "ornamental" were in the landscaped areas around the visitors' center. See Appendix F for list of species recorded by previous researchers but not by this inventory effort. Species with "**" were not previously recorded at the Tumacácori unit (by Mouat et al. 1977, Bennett [year unknown], and/or specimens stored at University of Arizona herbarium). Park units: "CAL" = Calabazas; "GUV" = Guevavi; "TUM" = Tumacácori.

\begin{tabular}{|c|c|c|c|c|c|}
\hline \multirow[b]{2}{*}{ Family } & \multirow[b]{2}{*}{ Scientific name } & \multirow[b]{2}{*}{ Common name } & \multicolumn{3}{|c|}{ Park unit } \\
\hline & & & CAL & GUV & TUM \\
\hline \multirow[t]{6}{*}{ Acanthaceae } & Anisacanthus thurberi (Torr.) Gray ${ }^{\mathrm{b} c}$ & Thurber's desert honeysuckle & 0 & $\mathrm{D}$ & $\mathrm{D}$ \\
\hline & Carlowrightia arizonica Gray & Arizona wrightwort & & $\mathrm{D}$ & \\
\hline & Dicliptera resupinata (Vahl) Juss. ${ }^{\mathrm{b}} \mathrm{c}$ ** & Arizona foldwing & & & $\mathrm{D}$ \\
\hline & Elytraria imbricata (Vahl) Pers. ${ }^{b}$ ** & purple scalystem & & & D \\
\hline & Ruellia nudiflora (Engelm. \& Gray) Urban a c & violet wild petunia & & & D \\
\hline & Tetramerium nervosum Nees a b & hairy fournwort & 0 & $\mathrm{D}$ & D \\
\hline Agavaceae & Yucca elata (Engelm.) Engelm. & soaptree yucca & D & & \\
\hline Aizoaceae & Trianthema portulacastrum L. ${ }^{a}$ & desert horsepurslane & & $\mathrm{D}$ & D \\
\hline Aloeaceae & Aloe sp. L. a (ornamental) ** & aloe & & & D \\
\hline \multirow[t]{4}{*}{ Amaranthaceae } & Amaranthus palmeri S. Wats. ${ }^{a} \mathrm{~b} c$ & carelessweed & 0 & $\mathrm{D}$ & D \\
\hline & Gomphrena sonorae Torr. ${ }^{a}$ & Sonoran globe amaranth & & & D \\
\hline & $\begin{array}{l}\text { Guilleminea densa var. densa (Humb. \& Bonpl. ex } \\
\text { Willd.) Moq. }{ }^{\text {a }}\end{array}$ & small matweed & & 0 & $\mathrm{D}$ \\
\hline & Tidestromia sp. Standl. ${ }^{c * *}$ & honeysweet & & & 0 \\
\hline \multirow[t]{2}{*}{ Anacardiaceae } & Rhus lanceolata (Gray) Britt. a ** & prairie sumac & & & $D$ \\
\hline & Schinus molle L. a (ornamental) & American pepper & & & D \\
\hline \multirow[t]{6}{*}{ Apiaceae } & Bowlesia incana Ruiz \& Pavón a ** & bowlesia & & 0 & D \\
\hline & Conium maculatum $\mathrm{L} . \mathrm{b} * *$ & poison hemlock & & & D \\
\hline & $\begin{array}{l}\text { Cyclospermum leptophyllum (Pers.) Sprague ex } \\
\text { Britt. \& Wilson a b** }\end{array}$ & marsh parsley & & & $\mathrm{D}$ \\
\hline & Daucus pusillus Michx. ${ }^{\text {*** }}$ & American wild carrot & D & 0 & 0 \\
\hline & Hydrocotyle verticillata Thunb. ${ }^{b * *}$ & whorled marshpennywort & & & D \\
\hline & Spermolepis echinata (Nutt. ex DC.) Heller a ${ }^{* *}$ & bristly scaleseed & D & 0 & 0 \\
\hline \multirow[t]{2}{*}{ Apocynaceae } & Nerium oleander L. a (ornamental) ** & oleander & & & $\mathrm{D}$ \\
\hline & Vinca major L. a (ornamental) & bigleaf periwinkle & & & D \\
\hline Aristolochiaceae & Aristolochia watsonii Woot. \& Standl. a & Watson's dutchman's pipe & 0 & 0 & D \\
\hline \multirow[t]{2}{*}{ Asclepiadaceae } & $\begin{array}{l}\text { Funastrum cynanchoides ssp. cynanchoides (Dcne.) } \\
\text { Schlechter ac** }\end{array}$ & fringed twinevine & & & D \\
\hline & $\begin{array}{l}\text { Funastrum cynanchoides ssp. heterophyllum (Vail) } \\
\text { Kartesz, comb. nov. ined. a }\end{array}$ & Hartweg's twinevine & & & $\mathrm{D}$ \\
\hline \multirow[t]{20}{*}{ Asteraceae } & Acourtia nana (Gray) Reveal \& King & dwarf desertpeony & D & & \\
\hline & Agoseris heterophylla (Nutt.) Greene a ${ }^{* *}$ & annual agoseris & & & $\mathrm{D}$ \\
\hline & Ambrosia artemisiifolia L. & annual ragweed & & $\mathrm{D}$ & \\
\hline & Ambrosia confertiflora DC. a b c & weakleaf burr ragweed & D & $\mathrm{D}$ & D \\
\hline & Ambrosia trifida L. a b c** & great ragweed & & & D \\
\hline & Antheropeas lanosum (Gray) Rydb. & white easterbonnets & D & 0 & \\
\hline & Artemisia ludoviciana Nutt. $\mathrm{b} c * *$ & white sagebrush & D & & $\mathrm{D}$ \\
\hline & Baccharis salicifolia (Ruiz \& Pavón) Pers. ${ }^{b}$ c ** & mule's fat & & & D \\
\hline & Baccharis sarothroides Gray a b c ** & desertbroom & 0 & 0 & D \\
\hline & Baileya multiradiata Harvey \& Gray ex Gray a ** & desert marigold & D & & 0 \\
\hline & Bidens laevis (L.) B.S.P. ${ }^{b}$ & smooth beggartick & & & D \\
\hline & Bidens leptocephala Sherff a c & fewflower beggarticks & D & $\mathrm{D}$ & D \\
\hline & Calycoseris wrightii Gray ${ }^{\text {*** }}$ & white tackstem & D & & D \\
\hline & Chaetopappa ericoides (Torr.) Nesom & rose heath & D & & \\
\hline & Cirsium neomexicanum Gray a ${ }^{\text {** }}$ & New Mexico thistle & D & & D \\
\hline & Conyza bonariensis (L.) Cronq. ${ }^{\text {a } * *}$ & asthmaweed & & & D \\
\hline & Conyza canadensis (L.) Cronq. a b & Canada horseweed & D & $\mathrm{D}$ & 0 \\
\hline & Erigeron arisolius Nesom & arid throne fleabane & D & & \\
\hline & Erigeron divergens Torr. \& Gray a $* *$ & spreading fleabane & 0 & $\mathrm{D}$ & D \\
\hline & Evax verna var. verna Raf. a ** & spring pygmycudweed & 0 & $\mathrm{D}$ & 0 \\
\hline
\end{tabular}




\begin{tabular}{|c|c|c|c|c|c|}
\hline \multirow[b]{2}{*}{ Family } & \multirow[b]{2}{*}{ Scientific name } & \multirow[b]{2}{*}{ Common name } & \multicolumn{3}{|c|}{ Park unit } \\
\hline & & & $\mathrm{CAL}$ & GUV & TUM \\
\hline \multirow[t]{38}{*}{ Asteraceae } & Gamochaeta purpurea (L.) Cabrera ${ }^{\text {** }}$ & spoonleaf purple everlasting & & & $\mathrm{D}$ \\
\hline & Gnaphalium palustre Nutt. ${ }^{a} * *$ & western marsh cudweed & 0 & $\mathrm{D}$ & D \\
\hline & Gutierrezia microcephala (DC.) Gray c ** & threadleaf snakeweed & D & & 0 \\
\hline & Helianthus annuus L. a b c** & common sunflower & D & & D \\
\hline & Helianthus petiolaris Nutt. ${ }^{c * *}$ & prairie sunflower & & & 0 \\
\hline & $\begin{array}{l}\text { Heliomeris Iongifolia var. annua (M.E. Jones) Yates c } \\
\star \star\end{array}$ & longleaf false goldeneye & & & 0 \\
\hline & $\begin{array}{l}\text { Heliomeris longifolia var. Iongifolia (Robins. \& } \\
\text { Greenm.) Cockerell }{ }^{b * *}\end{array}$ & longleaf false goldeneye & D & & D \\
\hline & Heliomeris multiflora var. multiflora Nutt. ${ }^{b * *}$ & showy goldeneye & & & D \\
\hline & Heterotheca subaxillaris (Lam.) Britt. \& Rusby a c** & camphorweed & 0 & $\mathrm{D}$ & 0 \\
\hline & Hymenoclea monogyra Torr. \& Gray ex Gray b c & singlewhorl burrobrush & & & $\mathrm{D}$ \\
\hline & Isocoma tenuisecta Greene ${ }^{c}$ & burroweed & & & 0 \\
\hline & Lactuca serriola L. a & prickly lettuce & 0 & & D \\
\hline & Laennecia coulteri (Gray) Nesom a ** & conyza & $\mathrm{D}$ & $\mathrm{D}$ & D \\
\hline & Laennecia sophiifolia (Kunth) Nesom & leafy marshtail & & $\mathrm{D}$ & \\
\hline & Machaeranthera gracilis (Nutt.) Shinners ${ }^{\text {** }}$ & slender goldenweed & $D$ & $\mathrm{D}$ & $\mathrm{O}$ \\
\hline & Machaeranthera pinnatifida (Hook.) Shinners ${ }^{c * *}$ & lacy tansyaster & $\mathrm{D}$ & & 0 \\
\hline & Machaeranthera tagetina Greene ${ }^{a} * *$ & mesa tansyaster & & $\mathrm{D}$ & D \\
\hline & Machaeranthera tanacetifolia (Kunth) Nees & tanseyleaf tansyaster & $\mathrm{D}$ & $\mathrm{D}$ & \\
\hline & Malacothrix clevelandii Gray a ** & Cleveland's desertdandelion & 0 & & D \\
\hline & Malacothrix fendleri Gray a b & Fendler's desertdandelion & $\mathrm{D}$ & $\mathrm{D}$ & D \\
\hline & Malacothrix glabrata (Gray ex D.C. Eat.) Gray a & smooth desertdandelion & & & D \\
\hline & Melampodium longicorne Gray ${ }^{b} * *$ & Arizona blackfoot & $\mathrm{D}$ & & D \\
\hline & Parthenice mollis Gray & annual monsterwort & & $\mathrm{D}$ & \\
\hline & $\begin{array}{l}\text { Pseudognaphalium canescens ssp. canescens (DC.) } \\
\text { W.A. Weber }{ }^{* *}\end{array}$ & Wright's cudweed & & D & $\mathrm{D}$ \\
\hline & $\begin{array}{l}\text { Pseudognaphalium leucocephalum (Gray) A. Anderb. } \\
\text { a b** }\end{array}$ & white cudweed & D & & D \\
\hline & Rafinesquia neomexicana Gray ${ }^{\text {* } *}$ & New Mexico plumseed & $\mathrm{D}$ & & D \\
\hline & $\begin{array}{l}\text { Senecio flaccidus var. douglasii (DC.) B.L. Turner \& } \\
\text { T.M. Barkl. b** }\end{array}$ & Douglas' ragwort & & & D \\
\hline & Senecio flaccidus var. flaccidus Less. ${ }^{c *}$ & threadleaf ragwort & & & 0 \\
\hline & Sonchus asper (L.) Hill a c ** & spiny sowthistle & & & D \\
\hline & Tagetes minuta L. ${ }^{* * *}$ & muster John Henry & & & D \\
\hline & Tithonia sp. Desf. ex Juss. ${ }^{c}$ & tithonia & & & 0 \\
\hline & Tithonia thurberi Gray ${ }^{a}$ & Arizona sunflowerweed & 0 & $\mathrm{D}$ & 0 \\
\hline & Trixis californica Kellogg a ${ }^{* *}$ & American threefold & & & D \\
\hline & Uropappus lindleyi (DC.) Nutt. ${ }^{\text {a }}$ & Lindley's silverpuffs & $\mathrm{D}$ & 0 & 0 \\
\hline & Viguiera sp. Kunth ${ }^{* * *}$ & goldeneye & & & 0 \\
\hline & Xanthium strumarium L. ${ }^{\mathrm{b}} \mathrm{c} * *$ & rough cockleburr & & & D \\
\hline & $\begin{array}{l}\text { Xanthocephalum gymnospermoides (Gray) Benth. \& } \\
\text { Hook. f. }\end{array}$ & San Pedro matchweed & & $\mathrm{D}$ & \\
\hline & Zinnia acerosa (DC.) Gray & desert zinnia & D & & \\
\hline Berberidaceae & Nandina sp. Thunb. ${ }^{\text {a }}$ (ornamental) ${ }^{* *}$ & nandina & & & D \\
\hline Bignoniaceae & Chilopsis linearis (Cav.) Sweet ${ }^{b}$ & desert willow & & & D \\
\hline Bixaceae & Amoreuxia palmatifida Moc. \& Sessé ex DC. ${ }^{c * *}$ & Mexican yellowshow & & & 0 \\
\hline Boraginaceae & $\begin{array}{l}\text { Amsinckia menziesii var. intermedia (Fisch \& C.A. } \\
\text { Mey.) Ganders }{ }^{a}\end{array}$ & common fiddleneck & & & D \\
\hline & Cryptantha sp. Lehm. ex G. Don ${ }^{c}$ & cryptantha & $\mathrm{D}$ & & O \\
\hline & Cryptantha angustifolia (Torr.) Greene ${ }^{a * *}$ & Panamint cryptantha & & 0 & D \\
\hline & Cryptantha micrantha (Torr.) I.M. Johnston a ** & redroot cryptantha & & & D \\
\hline & Cryptantha nevadensis A. Nels. \& Kennedy & Nevada cryptantha & D & & \\
\hline & Cryptantha pterocarya (Torr.) Greene & wingnut cryptantha & 0 & $\mathrm{D}$ & \\
\hline & Cryptantha pusilla (Torr. \& Gray) Greene & low cryptantha & $\mathrm{D}$ & & \\
\hline & Lappula occidentalis var. occidentalis (S. Wats.) & & & & \\
\hline & Greene $^{a}$ & flatspine stickseed & $D$ & 0 & D \\
\hline & Pectocarya heterocarpa (I.M. Johnston) I.M. Johnston & chuckwalla combseed & & $\mathrm{D}$ & \\
\hline
\end{tabular}




\begin{tabular}{|c|c|c|c|c|c|}
\hline \multirow[b]{2}{*}{ Family } & \multirow[b]{2}{*}{ Scientific name } & \multirow[b]{2}{*}{ Common name } & \multicolumn{3}{|c|}{ Park unit } \\
\hline & & & $\mathrm{CAL}$ & GUV & TUM \\
\hline \multirow[t]{3}{*}{ Boraginaceae } & Pectocarya recurvata I.M. Johnston ${ }^{\text {a }}$ ** & curvenut combseed & $\mathrm{D}$ & $\mathrm{D}$ & 0 \\
\hline & Plagiobothrys arizonicus (Gray) Greene ex Gray a ** & Arizona popcornflower & D & 0 & 0 \\
\hline & Plagiobothrys pringlei Greene & Pringle's speargrass & & $\mathrm{D}$ & \\
\hline \multirow[t]{11}{*}{ Brassicaceae } & Capsella bursa-pastoris (L.) Medik. ${ }^{a * *}$ & shepherd's purse & & & $\mathrm{D}$ \\
\hline & Descurainia pinnata (Walt.) Britt. ${ }^{a}$ & western tansymustard & D & 0 & $\mathrm{D}$ \\
\hline & Descurainia sophia (L.) Webb ex Prantl a ** & herb sophia & 0 & $\mathrm{D}$ & D \\
\hline & Draba cuneifolia var. integrifolia S. Wats. & wedgeleaf draba & D & & \\
\hline & Erysimum repandum $\mathrm{L}$. & spreading wallflower & & $\mathrm{D}$ & \\
\hline & Lepidium sp. L. a c & pepperweed & & & D \\
\hline & Lepidium lasiocarpum Nutt. a & shaggyfruit pepperweed & D & & $\mathrm{D}$ \\
\hline & Lepidium thurberi Woot. a c & Thurber's pepperweed & 0 & $\mathrm{D}$ & $\mathrm{D}$ \\
\hline & Lesquerella gordonii (Gray) S. Wats. ${ }^{\text {a }}$ & gordon bladderpod & 0 & 0 & D \\
\hline & Rorippa nasturtium-aquaticum (L.) Hayek b ** & watercress & & & D \\
\hline & Sisymbrium irio L. ${ }^{\text {a }}$ & London rocket & 0 & 0 & D \\
\hline \multirow[t]{7}{*}{ Cactaceae } & Ferocactus wislizeni (Engelm.) Britt. \& Rose ${ }^{b}$ & candy barrelcactus & $\mathrm{D}$ & 0 & 0 \\
\hline & Opuntia ficus-indica (L.) P. Mill. a (ornamental) ** & tuna cactus & & & $\mathrm{D}$ \\
\hline & Opuntia leptocaulis DC. & Christmas cactus & D & & \\
\hline & Opuntia macrorhiza Engelm. & twistspine pricklypear & $\mathrm{D}$ & & \\
\hline & Opuntia phaeacantha var. laevis (Coult.) L. Benson b & tulip pricklypear & 0 & $\mathrm{D}$ & 0 \\
\hline & $\begin{array}{l}\text { Opuntia santa-rita (Griffiths \& Hare) Rose }{ }^{a} \\
\text { (ornamental) }\end{array}$ & Santa Rita pricklypear & & & D \\
\hline & Opuntia spinosior (Engelm.) Toumey bc ** & walkingstick cactus & 0 & $\mathrm{D}$ & 0 \\
\hline \multirow[t]{2}{*}{ Campanulaceae } & Nemacladus glanduliferus Jepson & glandular threadplant & D & & \\
\hline & Triodanis perfoliata (L.) Nieuwl. ${ }^{\text {** }}$ & clasping Venus' looking-glass & 0 & & $\mathrm{D}$ \\
\hline \multirow[t]{2}{*}{ Caprifoliaceae } & Sambucus nigra ssp. canadensis (L.) R. Bolli a b** & common elderberry & 0 & 0 & $\mathrm{D}$ \\
\hline & Sambucus nigra ssp. cerulea (Raf.) R. Bolli c & blue elderberry & & & 0 \\
\hline Caryophyllaceae & Loeflingia squarrosa Nutt. & spreading pygmyleaf & & $\mathrm{D}$ & \\
\hline \multirow[t]{8}{*}{ Chenopodiaceae } & Atriplex canescens var. linearis (S. Wats.) Munz ${ }^{\text {a }}$ & thinleaf fourwing saltbush & & & $\mathrm{D}$ \\
\hline & Atriplex elegans (Moq.) D. Dietr. a b & wheelscale saltbush & D & $\mathrm{D}$ & D \\
\hline & Atriplex wrightii S. Wats. ${ }^{\text {a }}$ & Wright saltbush & & & $\mathrm{D}$ \\
\hline & Chenopodium sp. L. & goosefoot & D & $\mathrm{D}$ & \\
\hline & Chenopodium berlandieri Moq. & pitseed goosefoot & & $\mathrm{D}$ & \\
\hline & Chenopodium pratericola Rydb. ${ }^{\text {** }}$ & desert goosefoot & & & $\mathrm{D}$ \\
\hline & Chenopodium rubrum L. ${ }^{a * *}$ & red goosefoot & & & $\mathrm{D}$ \\
\hline & Salsola kali L. a b c & Russian thistle & 0 & $\mathrm{D}$ & D \\
\hline Commelinaceae & Commelina erecta $\mathrm{L}$. & whitemouth dayflower & 0 & $\mathrm{D}$ & \\
\hline \multirow[t]{5}{*}{ Convolvulaceae } & Evolvulus arizonicus Gray ${ }^{a}$ & wild dwarf morning-glory & O & $\mathrm{D}$ & $\mathrm{D}$ \\
\hline & Ipomoea barbatisepala Gray c ${ }^{* *}$ & canyon morning-glory & & & 0 \\
\hline & Ipomoea coccinea L. ${ }^{* * *}$ & redstar & & $\mathrm{D}$ & 0 \\
\hline & Ipomoea costellata Torr. ${ }^{\mathrm{c} * *}$ & crestrib morningglory & & $\mathrm{D}$ & 0 \\
\hline & Ipomoea hederacea Jacq. a c & ivyleaf morningglory & 0 & $\mathrm{D}$ & 0 \\
\hline \multirow[t]{4}{*}{ Cucurbitaceae } & Cucurbita digitata Gray a & fingerleaf gourd & 0 & 0 & $\mathrm{D}$ \\
\hline & Cucurbita foetidissima Kunth b c & Missouri gourd & 0 & $\mathrm{D}$ & D \\
\hline & Echinopepon wrightii (Gray) S. Wats. ${ }^{\mathrm{b} * *}$ & wild balsam apple & $\mathrm{D}$ & & $\mathrm{D}$ \\
\hline & Sicyosperma gracile Gray ${ }^{\text {** }}$ & climbing arrowheads & & & D \\
\hline \multirow[t]{2}{*}{ Cupressaceae } & $\begin{array}{l}\text { Juniperus coahuilensis (Martinez) Gaussen ex R.P. } \\
\text { Adams }\end{array}$ & redberry juniper & D & & \\
\hline & Platycladus orientalis (L.) Franco a (ornamental) ** & oriental arborvitae & & & D \\
\hline Cuscutaceae & Cuscuta umbellata Kunth b & flatglobe dodder & & & $\mathrm{D}$ \\
\hline \multirow[t]{2}{*}{ Cyperaceae } & Cyperus odoratus L. ${ }^{\text {** }}$ & fragrant flatsedge & & & $\mathrm{D}$ \\
\hline & Eleocharis montevidensis Kunth $\mathrm{b} * *$ & sand spikerush & & & D \\
\hline Equisetaceae & Equisetum laevigatum A. Braun $\mathrm{b}^{* *}$ & smooth horsetail & & & D \\
\hline \multirow[t]{5}{*}{ Euphorbiaceae } & Acalypha neomexicana Muell.-Arg. ${ }^{c}$ & New Mexico copperleaf & & & $\mathrm{D}$ \\
\hline & Acalypha ostryifolia Riddell b c & pineland threeseed mercury & & $\mathrm{D}$ & D \\
\hline & Argythamnia neomexicana Muell.-Arg. ${ }^{a * *}$ & New Mexico silverbush & & & D \\
\hline & Chamaesyce albomarginata (Torr. \& Gray) Small a ** & whitemargin sandmat & & & D \\
\hline & Chamaesyce florida (Engelm.) Millsp. ${ }^{\text {a }}$ ** & Chiricahua Mountain sandmat & & & $D$ \\
\hline
\end{tabular}




\begin{tabular}{|c|c|c|c|c|c|}
\hline \multirow[b]{2}{*}{ Family } & \multirow[b]{2}{*}{ Scientific name } & \multirow[b]{2}{*}{ Common name } & \multicolumn{3}{|c|}{ Park unit } \\
\hline & & & $\mathrm{CAL}$ & GUV & TUM \\
\hline \multirow[t]{9}{*}{ Euphorbiaceae } & Chamaesyce hirta (L.) Millsp. ${ }^{b}$ & pillpod sandmat & $\mathrm{D}$ & $\mathrm{D}$ & $\mathrm{D}$ \\
\hline & Chamaesyce hyssopifolia (L.) Small c & hyssopleaf sandmat & $\mathrm{D}$ & $\mathrm{D}$ & 0 \\
\hline & $\begin{array}{l}\text { Chamaesyce micromera (Boiss. ex Engelm.) Woot. \& } \\
\text { Standl. a ** }\end{array}$ & Sonoran sandmat & & & $D$ \\
\hline & Chamaesyce pediculifera (Engelm.) Rose \& Standl. & Carrizo Mountain sandmat & D & & \\
\hline & Cnidoscolus angustidens Torr. & mala mujer & D & & \\
\hline & Croton pottsii var. pottsii (Klotzsch) Muell.-Arg. & leatherweed & D & 0 & \\
\hline & Croton texensis (Klotzsch) Muell.-Arg. ${ }^{b * *}$ & Texas croton & & & D \\
\hline & Euphorbia heterophylla L. a c & Mexican fireplant & $\mathrm{D}$ & 0 & 0 \\
\hline & Tragia nepetifolia Cav. & catnip noseburn & D & & \\
\hline \multirow[t]{27}{*}{ Fabaceae } & Acacia constricta Benth. & whitethorn acacia & $\mathrm{D}$ & & \\
\hline & Acacia greggii Gray a b c & catclaw acacia & 0 & 0 & D \\
\hline & Astragalus allochrous Gray & halfmoon milkvetch & D & 0 & \\
\hline & Astragalus arizonicus Gray & Arizona milkvetch & D & & \\
\hline & Astragalus nuttallianus DC. ${ }^{\text {** }}$ & smallflowered milkvetch & 0 & $\mathrm{D}$ & 0 \\
\hline & Caesalpinia gilliesii (Hook.) Wallich ex D. Dietr. ${ }^{a}$ & bird-of-paradise shrub & & & D \\
\hline & Calliandra eriophylla Benth. & fairyduster & 0 & & \\
\hline & Cassia leptocarpa Benth. ${ }^{b * *}$ & woolly senna & & & D \\
\hline & Chamaecrista nictitans (L.) Moench ${ }^{\mathrm{b}}$ ** & partridge pea & & & D \\
\hline & $\begin{array}{l}\text { Chamaecrista nictitans var. leptadenia (Greenm.) } \\
\text { Gandhi \& Hatch }\end{array}$ & partridge pea & & D & \\
\hline & Crotalaria pumila Ortega $\mathrm{b} c * *$ & low rattlebox & & $\mathrm{D}$ & D \\
\hline & Desmodium neomexicanum Gray ${ }^{b} * *$ & New Mexico ticktrefoil & & $\mathrm{D}$ & D \\
\hline & Hoffmannseggia glauca (Ortega) Eifert a & Indian rushpea & & & D \\
\hline & Lotus humistratus Greene & foothill deervetch & $\mathrm{D}$ & 0 & \\
\hline & Lupinus concinnus J.G. Agardh a ** & scarlet lupine & & $\mathrm{D}$ & D \\
\hline & Marina calycosa (Gray) Barneby & San Pedro false prairie-clover & $\mathrm{D}$ & & \\
\hline & Medicago polymorpha L. a & burclover & & & D \\
\hline & Melilotus indicus (L.) All. a & annual yellow sweetclover & & & D \\
\hline & Melilotus officinalis (L.) Lam. ${ }^{c * *}$ & yellow sweetclover & & & 0 \\
\hline & Mimosa aculeaticarpa Ortega & catclaw mimosa & $D$ & & \\
\hline & $\begin{array}{l}\text { Mimosa aculeaticarpa var. biuncifera (Benth.) } \\
\text { Barneby } b^{* *}\end{array}$ & catclaw mimosa & & & D \\
\hline & Parkinsonia aculeata L. a (ornamental) & Jerusalem thorn & & & D \\
\hline & Parkinsonia florida (Benth. ex Gray) S. Wats. ${ }^{a}$ & blue paloverde & & & D \\
\hline & Phaseolus ritensis M.E. Jones & Santa Rita Mountain bean & & $\mathrm{D}$ & \\
\hline & Prosopis velutina Woot. a b c & velvet mesquite & 0 & 0 & $\mathrm{D}$ \\
\hline & $\begin{array}{l}\text { Rhynchosia senna var. texana (Torr. \& Gray) M.C. } \\
\text { Johnston }\end{array}$ & Texas snoutbean & $\mathrm{D}$ & $\mathrm{D}$ & \\
\hline & Senna bauhinioides (Gray) Irwin \& Barneby & twinleaf senna & D & 0 & \\
\hline Fouquieriaceae & Fouquieria splendens Engelm. & ocotillo & D & & \\
\hline Fumariaceae & Pseudofumaria lutea (L.) Borkh. ${ }^{a} * *$ & rock fumewort & 0 & $\mathrm{D}$ & 0 \\
\hline \multirow[t]{2}{*}{ Geraniaceae } & Erodium cicutarium (L.) L'Hér. ex Ait. a ${ }^{* *}$ & redstem stork's bill & & & D \\
\hline & Erodium texanum Gray & Texas stork's bill & $\mathrm{D}$ & & \\
\hline \multirow[t]{7}{*}{ Hydrophyllaceae } & Eucrypta micrantha (Torr.) Heller & dainty desert hideseed & D & & \\
\hline & Nama hispidum Gray a & bristly nama & 0 & 0 & D \\
\hline & Phacelia sp. Juss. & phacelia & D & & \\
\hline & Phacelia affinis Gray & limestone phacelia & D & & \\
\hline & Phacelia arizonica Gray a & Arizona phacelia & D & 0 & 0 \\
\hline & Phacelia crenulata Torr. ex S. Wats. & cleftleaf wildheliotrope & D & & \\
\hline & Phacelia distans Benth. ${ }^{\text {a* }}$ & distant phacelia & 0 & & D \\
\hline Juglandaceae & Juglans major (Torr.) Heller a c & Arizona walnut & & & D \\
\hline Krameriaceae & Krameria erecta Willd. ex J.A. Schultes & littleleaf ratany & $\mathrm{D}$ & & \\
\hline \multirow[t]{3}{*}{ Lamiaceae } & Lamium amplexicaule L. a ** & henbit deadnettle & 0 & $\mathrm{D}$ & D \\
\hline & Marrubium vulgare L. a b c & horehound & & 0 & D \\
\hline & Salvia subincisa Benth. & sawtooth sage & $D$ & & \\
\hline Liliaceae & Calochortus kennedyi Porter & desert mariposa lily & D & & 0 \\
\hline
\end{tabular}




\begin{tabular}{|c|c|c|c|c|c|}
\hline \multirow[b]{2}{*}{ Family } & \multirow[b]{2}{*}{ Scientific name } & \multirow[b]{2}{*}{ Common name } & \multicolumn{3}{|c|}{ Park unit } \\
\hline & & & $\mathrm{CAL}$ & GUV & TUM \\
\hline \multirow[t]{3}{*}{ Liliaceae } & Dasylirion wheeleri S. Wats. & common sotol & $\mathrm{D}$ & & \\
\hline & $\begin{array}{l}\text { Dichelostemma capitatum (Benth.) Wood ssp. } \\
\text { capitatum }\end{array}$ & bluedicks & D & & 0 \\
\hline & Nothoscordum sp. Kunth a** & false garlic & & & D \\
\hline \multirow[t]{2}{*}{ Loasaceae } & $\begin{array}{l}\text { Mentzelia albicaulis (Dougl. ex Hook.) Dougl. ex Torr. } \\
\& \text { Gray a b c }\end{array}$ & whitestem blazingstar & 0 & D & D \\
\hline & Mentzelia aspera L. b c ** & tropical blazingstar & & $\mathrm{D}$ & D \\
\hline \multirow[t]{12}{*}{ Malvaceae } & Abutilon sp. P. Mill c** & Indian mallow & & & 0 \\
\hline & Abutilon mollicomum (Willd.) Sweet & Sonoran Indian mallow & 0 & $\mathrm{D}$ & \\
\hline & Abutilon parvulum Gray & dwarf Indian mallow & & $\mathrm{D}$ & \\
\hline & Anoda cristata (L.) Schlecht. ${ }^{c}$ & crested anoda & & $\mathrm{D}$ & 0 \\
\hline & Malva parviflora L. a & cheeseweed mallow & & & $\mathrm{D}$ \\
\hline & Malvella leprosa (Ortega) Krapov. & alkali mallow & & $\mathrm{D}$ & \\
\hline & Rhynchosida physocalyx (Gray) Fryxell a b c & buffpetal & 0 & $\mathrm{D}$ & D \\
\hline & Sida abutifolia P. Mill. a c & spreading fanpetals & D & $\mathrm{D}$ & 0 \\
\hline & Sida neomexicana Gray & New Mexico fanpetals & & $\mathrm{D}$ & \\
\hline & Sida spinosa L. & prickly fanpetals & & $\bar{D}$ & \\
\hline & Sphaeralcea angustifolia (Cav.) G. Don a & copper globemallow & & & D \\
\hline & Sphaeralcea emoryi Torr. ex Gray & Emory's globemallow & & $\mathrm{D}$ & \\
\hline Meliaceae & Melia azedarach L . (ornamental) & Chinaberrytree & & & D \\
\hline Menispermaceae & Cocculus diversifolius DC. ${ }^{\text {a } ~}$ c & snailseed & & & D \\
\hline Molluginaceae & Mollugo verticillata $\mathrm{L}$. & green carpetweed & D & & \\
\hline Moraceae & Morus microphylla Buckl. ${ }^{\mathrm{b}}$ ** & Texas mulberry & & & D \\
\hline \multirow[t]{8}{*}{ Nyctaginaceae } & Allionia incarnata L. ${ }^{a}$ & trailing windmills & D & 0 & D \\
\hline & Boerhavia coccinea P. Mill. a c & scarlet spiderling & 0 & 0 & D \\
\hline & Boerhavia erecta L. & erect spiderling & D & & \\
\hline & Boerhavia purpurascens Gray & purple spiderling & D & & \\
\hline & Boerhavia scandens L. a b c & climbing wartclub & D & 0 & D \\
\hline & Boerhavia spicata Choisy $b^{* *}$ & creeping spiderling & & & $\mathrm{D}$ \\
\hline & Boerhavia watsonii Standl. a ${ }^{* *}$ & & & & D \\
\hline & Mirabilis longiflora L. $\mathrm{b} c * *$ & sweet four o'clock & & & D \\
\hline \multirow[t]{2}{*}{ Oleaceae } & Fraxinus velutina Torr. $\mathrm{a} b \mathrm{c} * *$ & velvet ash & & & $\mathrm{D}$ \\
\hline & Ligustrum lucidum Ait. f. a (ornamental) ** & glossy privet & & & D \\
\hline \multirow[t]{6}{*}{ Onagraceae } & $\underset{* *}{\text { Camissonia californica (Nutt. ex Torr. \& Gray) Raven }{ }^{b}}$ & California suncup & & & $D$ \\
\hline & Camissonia chamaenerioides (Gray) Raven a ** & longcapsule suncup & & & D \\
\hline & Gaura mollis James a b & velvetweed & 0 & 0 & D \\
\hline & Ludwigia repens J.R. Forst. $b$ ** & creeping primrose-willow & & & $\mathrm{D}$ \\
\hline & Oenothera primiveris Gray a ** & desert evening-primrose & D & 0 & D \\
\hline & Oenothera rosea L'Her. ex Ait ${ }^{b}$ ** & rose evening-primrose & & & D \\
\hline Orobanchaceae & Orobanche cooperi (Gray) Heller & desert broomrape & D & & \\
\hline \multirow[t]{2}{*}{ Oxalidaceae } & Oxalis sp. L. (species with subterranean bulbs) & woodsorrel & D & & \\
\hline & Oxalis corniculata L. ${ }^{\text {** }}$ & creeping woodsorrel & & & D \\
\hline \multirow[t]{4}{*}{ Papaveraceae } & Argemone pleiacantha Greene $b c * *$ & southwestern pricklypoppy & & & D \\
\hline & Argemone polyanthemos (Fedde) G.B. Ownbey a c & crested pricklypoppy & & & $\mathrm{D}$ \\
\hline & $\begin{array}{l}\text { Eschscholzia californica ssp. mexicana (Greene) C. } \\
\text { Clark }^{\text {a }}\end{array}$ & California poppy & 0 & 0 & $\mathrm{D}$ \\
\hline & Papaver rhoeas L. a ** & corn poppy & & & D \\
\hline Passifloraceae & Passiflora mexicana Juss. a b & Mexican passionflower & 0 & 0 & D \\
\hline \multirow[t]{2}{*}{ Pedaliaceae } & Proboscidea althaeifolia (Benth.) Dcne. & desert unicorn-plant & D & & \\
\hline & Proboscidea parviflora (Woot.) Woot. \& Standl. a b c & doubleclaw & & & $\mathrm{D}$ \\
\hline Phytolaccaceae & Rivina humilis $\mathrm{L}$. a b c & rougeplant & 0 & $\mathrm{D}$ & D \\
\hline Pinaceae & Pinus eldarica Medw. ${ }^{b * *}$ & Afghan pine & & & D \\
\hline \multirow[t]{3}{*}{ Plantaginaceae } & Plantago major $\mathrm{L} . \mathrm{b} * *$ & common plantain & & & $D$ \\
\hline & Plantago patagonica Jacq. ${ }^{\text {a** }}$ & woolly plantain & & 0 & D \\
\hline & Plantago virginica $\mathrm{L}$. & Virginia plantain & & $\mathrm{D}$ & \\
\hline Poaceae & Aristida adscensionis L. a c & sixweeks threeawn & 0 & $\mathrm{D}$ & $\mathrm{D}$ \\
\hline
\end{tabular}




\begin{tabular}{|c|c|c|c|c|c|}
\hline \multirow[b]{2}{*}{ Family } & \multirow[b]{2}{*}{ Scientific name } & \multirow[b]{2}{*}{ Common name } & \multicolumn{3}{|c|}{ Park unit } \\
\hline & & & $\overline{C A L}$ & GUV & TUM \\
\hline \multirow[t]{54}{*}{ Poaceae } & Aristida purpurea Nutt.$^{c^{* *}}$ & purple threeawn & & & 0 \\
\hline & Aristida purpurea var. nealleyi (Vasey) Allred a ${ }^{* *}$ & blue threeawn & 0 & & D \\
\hline & Aristida purpurea var. purpurea Nutt. & purple threeawn & D & & \\
\hline & $\begin{array}{l}\text { Aristida schiedeana var. orcuttiana (Vasey) Allred \& } \\
\text { Valdés-Reyna }{ }^{* * *}\end{array}$ & Orcutt's threeawn & & & 0 \\
\hline & Aristida ternipes Cav. & spidergrass & D & 0 & \\
\hline & Aristida ternipes var. gentilis (Henr.) Allred & spidergrass & & $\mathrm{D}$ & \\
\hline & Aristida ternipes var. ternipes Cav. a c & spidergrass & & & 0 \\
\hline & Arundo donax L. ${ }^{\mathrm{c} * *}$ & giant reed & & & 0 \\
\hline & Avena fatua $\mathrm{L} .{ }^{\mathrm{a}}$ & wild oat & & & D \\
\hline & Bothriochloa barbinodis (Lag.) Herter $\mathrm{b} * *$ & cane bluestem & D & $D$ & D \\
\hline & Bouteloua aristidoides (Kunth) Griseb. a c & needle grama & 0 & $\mathrm{D}$ & D \\
\hline & Bouteloua barbata Lag. ${ }^{c}$ & sixweeks grama & & & 0 \\
\hline & Bouteloua curtipendula (Michx.) Torr. a & sideoats grama & 0 & $\mathrm{D}$ & 0 \\
\hline & Bouteloua gracilis (Willd. ex Kunth) Lag. ex Griffiths ${ }^{c}$ & blue grama & & & 0 \\
\hline & Bouteloua radicosa (Fourn.) Griffiths ${ }^{c * *}$ & purple grama & & & 0 \\
\hline & Bouteloua repens (Kunth) Scribn. \& Merr. ${ }^{{ }^{* *}}$ & slender grama & D & $\mathrm{D}$ & 0 \\
\hline & Bouteloua rothrockii Vasey a b c & Rothrock's grama & D & $\mathrm{D}$ & D \\
\hline & Bromus catharticus Vahl a & rescuegrass & & $\mathrm{D}$ & D \\
\hline & Cenchrus longispinus (Hack.) Fern. ${ }^{c * *}$ & field sandbur & & & 0 \\
\hline & Cenchrus spinifex Cav. a b c & coastal sandbur & 0 & & $\mathrm{D}$ \\
\hline & Chloris virgata Sw. a c & feather fingergrass & 0 & 0 & D \\
\hline & Cottea pappophoroides Kunth b & cotta grass & & $\mathrm{D}$ & D \\
\hline & Cynodon dactylon (L.) Pers. a b c & Bermudagrass & 0 & $\mathrm{D}$ & D \\
\hline & Dactyloctenium aegyptium (L.) Willd. a ** & Egyptian grass & & & D \\
\hline & Dasyochloa pulchella (Kunth) Willd. ex Rydb. ${ }^{a}$ ** & low woollygrass & D & & 0 \\
\hline & Digitaria californica (Benth.) Henr. a & Arizona cottontop & & & D \\
\hline & Digitaria sanguinalis (L.) Scop. ${ }^{\text {a b c }}$ & hairy crabgrass & & & D \\
\hline & Echinochloa colona (L.) Link ${ }^{c * *}$ & jungle rice & & & 0 \\
\hline & Echinochloa crus-galli (L.) Beauv. $\mathrm{b} * *$ & barnyardgrass & & & D \\
\hline & Elymus elymoides (Raf.) Swezey a b** & squirreltail & 0 & 0 & D \\
\hline & Eragrostis barrelieri Daveau a $* *$ & Mediterranean lovegrass & & & D \\
\hline & Eragrostis cilianensis (All.) Vign. ex Janchen a c & stinkgrass & 0 & $\mathrm{D}$ & 0 \\
\hline & Eragrostis curvula (Schrad.) Nees a c** & weeping lovegrass & 0 & & D \\
\hline & Eragrostis intermedia A.S. Hitchc. ${ }^{c * *}$ & plains lovegrass & & & 0 \\
\hline & Eragrostis lehmanniana Nees a c ${ }^{* *}$ & Lehmann lovegrass & 0 & $\mathrm{D}$ & D \\
\hline & Eriochloa acuminata (J. Presl) Kunth c & tapertip cupgrass & & & 0 \\
\hline & Eriochloa acuminata var. minor (Vasey) R.B. Shaw & tapertip cupgrass & & $\mathrm{D}$ & \\
\hline & Hilaria belangeri (Steud.) Nash a ** & curly-mesquite & D & & D \\
\hline & $\begin{array}{l}\text { Hordeum murinum ssp. glaucum (Steud.) Tzvelev } \\
\mathrm{a} * *\end{array}$ & smooth barley & & & $\mathrm{D}$ \\
\hline & Hordeum pusillum Nutt. a & little wildbarley & 0 & 0 & D \\
\hline & Hordeum vulgare $\mathrm{L} . \mathrm{a}^{* *}$ & common barley & & & D \\
\hline & Leptochloa dubia (Kunth) Nees a & green sprangletop & 0 & 0 & D \\
\hline & Leptochloa panicea ssp. mucronata (Michx.) Nowack a & mucronate sprangletop & & $\mathrm{D}$ & D \\
\hline & Muhlenbergia fragilis Swallen ${ }^{*} * *$ & delicate muhly & & & 0 \\
\hline & Muhlenbergia microsperma (DC.) Trin. ${ }^{a}$ & littleseed muhly & & & D \\
\hline & Panicum hallii Vasey & Hall's panicgrass & D & & \\
\hline & Panicum hirticaule J. Presl & Mexican panicgrass & & $\mathrm{D}$ & \\
\hline & Panicum obtusum Kunth a & vine mesquite & & & D \\
\hline & Paspalum dilatatum Poir. $\mathrm{b} * *$ & dallisgrass & & & D \\
\hline & Poa bigelovii Vasey \& Scribn. ${ }^{\text {a }}$ & Bigelow's bluegrass & D & & D \\
\hline & Polypogon monspeliensis (L.) Desf. $b * *$ & annual rabbitsfoot grass & & & D \\
\hline & Schismus arabicus Nees a ${ }^{* *}$ & Arabian schismus & D & & 0 \\
\hline & Schismus barbatus (Loefl. ex L.) Thellung a ** & $\begin{array}{l}\text { common Mediterranean } \\
\text { grass }\end{array}$ & D & 0 & D \\
\hline & Setaria grisebachii Fourn. a c & Grisebach's bristlegrass & 0 & $\mathrm{D}$ & 0 \\
\hline
\end{tabular}




\begin{tabular}{|c|c|c|c|c|c|}
\hline \multirow[b]{2}{*}{ Family } & \multirow[b]{2}{*}{ Scientific name } & \multirow[b]{2}{*}{ Common name } & \multicolumn{3}{|c|}{ Park unit } \\
\hline & & & $\mathrm{CAL}$ & GUV & TUM \\
\hline \multirow[t]{15}{*}{ Poaceae } & Setaria leucopila (Scribn. \& Merr.) K. Schum. ${ }^{\text {b**}}$ & streambed bristlegrass & & & $\mathrm{D}$ \\
\hline & Setaria pumila (Poir.) Roemer \& J.A. Schultes ${ }^{b} * *$ & yellow bristlegrass & & & D \\
\hline & Setaria viridis (L.) Beauv. ${ }^{\text {a } * *}$ & green bristlegrass & & & D \\
\hline & Setaria vulpiseta (Lam.) Roemer \& J.A. Schultes a & plains bristlegrass & 0 & $\mathrm{D}$ & D \\
\hline & Sorghum bicolor ssp. bicolor (L.) Moench a ** & grain sorghum & & $\mathrm{D}$ & D \\
\hline & $\begin{array}{l}\text { Sorghum bicolor ssp. drummondii (Nees ex } \\
\text { Steud.) de Wet \& Harlan a }{ }^{* *}\end{array}$ & broom-corn & & & 0 \\
\hline & Sorghum halepense (L.) Pers. a b c & Johnsongrass & 0 & & D \\
\hline & Sporobolus airoides (Torr.) Torr. ${ }^{b * *}$ & alkali sacaton & & & D \\
\hline & Sporobolus cryptandrus (Torr.) Gray a b c & sand dropseed & 0 & $\mathrm{D}$ & D \\
\hline & Sporobolus wrightii Munro ex Scribn. & big sacaton & 0 & $\mathrm{D}$ & \\
\hline & Tridens muticus (Torr.) Nash & slim tridens & D & & \\
\hline & $\begin{array}{l}\text { Urochloa arizonica (Scribn. \& Merr.) O. Morrone \& F. } \\
\text { Zuloaga }{ }^{c}\end{array}$ & Arizona signalgrass & & D & 0 \\
\hline & Urochloa fasciculata (Sw.) R. Webster a $* *$ & browntop signalgrass & & & D \\
\hline & Vulpia octoflora (Walt.) Rydb. & sixweeks fescue & 0 & $\mathrm{D}$ & 0 \\
\hline & Vulpia octoflora var. octoflora (Walt.) Rydb. ${ }^{a * *}$ & sixweeks fescue & & & $\mathrm{D}$ \\
\hline \multirow[t]{4}{*}{ Polemoniaceae } & Eriastrum diffusum (Gray) Mason a c & miniature woollystar & 0 & $\mathrm{D}$ & 0 \\
\hline & Gilia mexicana A.\& V. Grant a ** & El Paso gilia & D & $\mathrm{D}$ & D \\
\hline & Gilia sinuata Dougl. ex Benth. ${ }^{a}$ & rosy gilia & & & 0 \\
\hline & Ipomopsis longiflora (Torr.) V. Grant & flaxflowered ipomopsis & D & & \\
\hline Polygalaceae & Polygala barbeyana Chod. & blue milkwort & D & & \\
\hline \multirow{7}{*}{ Polygonaceae } & Eriogonum abertianum Torr. ${ }^{\text {a }}$ & Abert's buckwheat & D & $\mathrm{D}$ & D \\
\hline & Eriogonum deflexum Torr. ${ }^{\mathrm{c} * *}$ & flatcrown buckwheat & & & 0 \\
\hline & Eriogonum polycladon Benth. ${ }^{\mathrm{b}} \mathrm{c} * *$ & sorrel buckwheat & & & D \\
\hline & Polygonum argyrocoleon Steud. ex Kunze ${ }^{b * *}$ & silversheath knotweed & & & D \\
\hline & Polygonum punctatum Ell. $\mathrm{b}^{* *}$ & dotted smartweed & & & $\mathrm{D}$ \\
\hline & Rumex sp. L. ${ }^{\mathrm{b} * *}$ & dock & & & D \\
\hline & Rumex crispus L. ${ }^{b * *}$ & curly dock & & & D \\
\hline \multirow[t]{6}{*}{ Portulacaceae } & Calandrinia ciliata (Ruiz \& Pavon) DC. ${ }^{\text {a* }}$ & fringed redmaids & D & 0 & 0 \\
\hline & Cistanthe parryi var. parryi (Gray) Hershkovitz & Parry's pussypaws & & $\mathrm{D}$ & \\
\hline & Portulaca oleracea L. a ** & little hogweed & & & D \\
\hline & Portulaca suffrutescens Engelm. & shrubby purslane & & $\mathrm{D}$ & \\
\hline & Talinum aurantiacum Engelm. & orange fameflower & $\mathrm{D}$ & 0 & \\
\hline & Talinum paniculatum (Jacq.) Gaertn. a b & jewels of Opar & 0 & 0 & D \\
\hline Primulaceae & Androsace occidentalis Pursh a ** & western rockjasmine & D & 0 & 0 \\
\hline Punicaceae & Punica granatum L. a (ornamental) & pomegranate & & & $\mathrm{D}$ \\
\hline \multirow[t]{4}{*}{ Ranunculaceae } & Clematis drummondii Torr. \& Gray ${ }^{c}$ & Drummond's clematis & & & 0 \\
\hline & Clematis ligusticifolia Nutt. a b & western white clematis & & & D \\
\hline & Delphinium scaposum Greene & tall mountain larkspur & D & & \\
\hline & Myosurus minimus $\mathrm{L}$. & tiny mousetail & & $\mathrm{D}$ & \\
\hline \multirow[t]{3}{*}{ Rhamnaceae } & Ceanothus greggii Gray ${ }^{\mathrm{c} * *}$ & desert ceanothus & & & 0 \\
\hline & Condalia mexicana Schlecht. ${ }^{a} * *$ & Mexican bluewood & & & D \\
\hline & Ziziphus obtusifolia (Hook. ex Torr. \& Gray) Gray a b c & lotebush & 0 & 0 & $\mathrm{D}$ \\
\hline \multirow[t]{3}{*}{ Salicaceae } & Populus fremontii S. Wats. a b c & Fremont cottonwood & & & $\mathrm{D}$ \\
\hline & Salix gooddingii Ball $b c^{* *}$ & Goodding's willow & & & D \\
\hline & Salix taxifolia Kunth ${ }^{c * *}$ & yewleaf willow & & & 0 \\
\hline \multirow[t]{10}{*}{ Scrophulariaceae } & Castilleja exserta (Heller) Chuang \& Heckard a ** & exserted Indian paintbrush & & & D \\
\hline & Leucophyllum sp. Bonpl. a (ornamental) ** & barometerbush & & & D \\
\hline & Maurandella antirrhiniflora (Humb. \& Bonpl. ex Willd.) & & & & \\
\hline & Rothm. & roving sailor & 0 & & \\
\hline & Mimulus guttatus DC. ${ }^{* * *}$ & common monkeyflower & & $\mathrm{D}$ & D \\
\hline & Mimulus rubellus Gray & little redstem monkeyflower & $\mathrm{D}$ & 0 & \\
\hline & Nuttallanthus texanus (Scheele) D.A. Sutton a ${ }^{* *}$ & Texas toadflax & & 0 & D \\
\hline & Penstemon parryi (Gray) Gray & Parry's beardtongue & D & & \\
\hline & Veronica anagallis-aquatica L. $\mathrm{b}$ ** & water speedwell & & & D \\
\hline & Veronica peregrina $\mathrm{L}$. a $\mathrm{b} * \star$ & neckweed & 0 & $\mathrm{D}$ & D \\
\hline
\end{tabular}




\begin{tabular}{|c|c|c|c|c|c|}
\hline \multirow[b]{2}{*}{ Family } & \multirow[b]{2}{*}{ Scientific name } & \multirow[b]{2}{*}{ Common name } & \multicolumn{3}{|c|}{ Park unit } \\
\hline & & & $\mathrm{CAL}$ & GUV & TUM \\
\hline Simaroubaceae & Ailanthus altissima (P. Mill.) Swingle ${ }^{b * *}$ & tree of heaven & & & $\mathrm{D}$ \\
\hline \multirow[t]{9}{*}{ Solanaceae } & Calibrachoa parviflora (Juss.) D'Arcy b** & seaside petunia & & & D \\
\hline & Chamaesaracha sp. (Gray) Benth. ${ }^{* *}$ & five eyes & & & 0 \\
\hline & Datura quercifolia Kunth ${ }^{b}$ ** & Chinese thorn-apple & & & D \\
\hline & Datura wrightii Regel a b c & sacred thorn-apple & D & & D \\
\hline & Lycium andersonii Gray a b & water jacket & $\mathrm{O}$ & 0 & D \\
\hline & Nicotiana glauca Graham ${ }^{b}$ ** & tree tobacco & & & D \\
\hline & Physalis acutifolia (Miers) Sandw. ${ }^{a}$ & sharpleaf groundcherry & & & D \\
\hline & Physalis longifolia Nutt. & longleaf groundcherry & & $\mathrm{D}$ & \\
\hline & Solanum elaeagnifolium Cav. a b & silverleaf nightshade & 0 & & D \\
\hline \multirow[t]{2}{*}{ Tamaricaceae } & Tamarix sp. L. c & tamarisk & & & 0 \\
\hline & Tamarix ramosissima Ledeb. ${ }^{b}$ & saltcedar & & & D \\
\hline \multirow[t]{2}{*}{ Ulmaceae } & Celtis laevigata var. reticulata (Torr.) L. Benson a c & netleaf hackberry & 0 & $\mathrm{D}$ & 0 \\
\hline & Celtis pallida Torr. a b & spiny hackberry & & & D \\
\hline \multirow[t]{2}{*}{ Urticaceae } & Parietaria sp. L. ${ }^{c * *}$ & pellitory & & & 0 \\
\hline & Parietaria pensylvanica Muhl. ex Willd. & Pennsylvania pellitory & $\mathrm{D}$ & & \\
\hline \multirow[t]{2}{*}{ Verbenaceae } & Glandularia gooddingii (Briq.) Solbrig a $* *$ & southwestern mock vervain & D & & D \\
\hline & Tetraclea coulteri Gray & Coulter's wrinklefruit & D & & \\
\hline Viscaceae & Phoradendron californicum Nutt. ${ }^{a}$ & mesquite mistletoe & 0 & 0 & D \\
\hline Vitaceae & Vitis arizonica Engelm. ${ }^{a}$ & canyon grape & & 0 & D \\
\hline \multirow[t]{3}{*}{ Zygophyllaceae } & Kallstroemia grandiflora Torr. ex Gray & Arizona poppy & $\mathrm{D}$ & & \\
\hline & $\begin{array}{l}\text { Larrea tridentata (Sessé \& Moc. ex DC.) Coville a } \\
\text { (possibly ornamental) }\end{array}$ & creosote bush & & & D \\
\hline & Tribulus terrestris L. a b & puncturevine & & $\mathrm{D}$ & $\mathrm{D}$ \\
\hline
\end{tabular}

a Species recorded during 2000-2001 survey of the original Tumacácori NHP boundary.

b Species recorded during 2002-2003 survey of the Tumacácori expansion area.

c Species recorded on modular plots. 
Appendix B. Fish species recorded in the Santa Cruz River and Tumacácori Channel by University of Arizona Inventory personnel, Tumacácori NHP, 2001-2002. Species in bold-faced type are non-native.

\begin{tabular}{|c|c|c|c|c|c|}
\hline Order & Family & Scientific name & Common name & $\mathrm{ESA}^{\mathrm{a}}$ & $\begin{array}{l}\text { ESA } \\
\text { date }\end{array}$ \\
\hline \multirow[t]{3}{*}{ Cypriniformes } & Cyprinidae & Agosia chrysogaster ${ }^{b}$ & longfin dace & SC & 1996 \\
\hline & Catostomidae & Catostomus insignis & Sonora sucker & SC & 1996 \\
\hline & & Catostomus clarkii & desert sucker & SC & 1996 \\
\hline \multirow[t]{2}{*}{ Cyprinodontiformes } & Poeciliidae & Gambusia affinis & western mosquitofish & & \\
\hline & & Poeciliopsis occidentalis occidentalis & Gila topminnow & LE & 1967 \\
\hline \multirow[t]{3}{*}{ Perciformes } & Centrarchidae & Lepomis cyanellus & green sunfish & & \\
\hline & & Lepomis macrochirus & bluegill sunfish & & \\
\hline & & Micropterus salmoides & largemouth bass & & \\
\hline
\end{tabular}

a ESA = Endangered Species Act: LE = "Listed Endangered", SC = "Species of Concern"; U.S. Fish and Wildlife Service (HDMS 2004).

b "Sensitive species"; Bureau of Land Management (HDMS 2004). 
Appendix C. Amphibian and reptile species that were observed (0), documented with photo voucher (P), or documented with specimen voucher (S) by University of Arizona Inventory personnel, Tumacácori

NHP, 2001-2002. Species in bold-faced type is non-native. See Appendix $L$ for additional information on voucher specimens. Park units: "CAL" = Calabazas; "GUV" = Guevavi; "TUM" = Tumacácori.

\begin{tabular}{|c|c|c|c|c|c|c|}
\hline \multirow[b]{2}{*}{ Order } & \multirow[b]{2}{*}{ Family } & \multirow[b]{2}{*}{ Scientific name } & \multirow[b]{2}{*}{ Common name } & \multicolumn{3}{|c|}{ Park unit } \\
\hline & & & & CAL & GUV & TUM \\
\hline \multirow[t]{7}{*}{ Anura } & Pelobatidae & Scaphiopus couchii & Couch's spadefoot & $P$ & $\mathrm{P}$ & $\mathrm{P}, \mathrm{S}$ \\
\hline & & Spea multiplicata & Mexican spadefoot & $P$ & $\mathrm{P}, \mathrm{S}$ & $\mathrm{P}$ \\
\hline & Bufonidae & Bufo alvarius & Colorado River toad & & & $\mathrm{P}$ \\
\hline & & Bufo woodhousii & Woodhouse's toad & & & $\mathrm{P}, \mathrm{S}$ \\
\hline & & Bufo cognatus & Great Plains toad & & & 0 \\
\hline & Ranidae & Rana catesbeiana & American bullfrog & & & $P$ \\
\hline & Microhylidae & Gastrophryne olivacea & Great Plains narrow-mouthed toad ${ }^{a}$ & & & 0 \\
\hline \multirow[t]{2}{*}{ Testudines } & Kinosternidae & Kinosternon sonoriense & Sonora mud turtle & & & $P$ \\
\hline & Emydidae & Terrapene ornata & ornate box turtle & 0 & & $P$ \\
\hline \multirow[t]{15}{*}{ Squamata } & Phyrnosomatide & Holbrookia maculata & common lesser earless lizard & 0 & 0 & $\mathrm{P}$ \\
\hline & & Sceloporus clarkii & Clark's spiny lizard & 0 & 0 & $\mathrm{P}, \mathrm{S}$ \\
\hline & & Sceloporus undulatus & eastern fence lizard & & & $\mathrm{P}$ \\
\hline & & Urosaurus ornatus & ornate tree lizard & $P$ & & $P$ \\
\hline & & Phrynosoma solare & regal horned lizard & $P$ & & $\mathrm{P}$ \\
\hline & Teiidae & Cnemidophorus uniparens & desert grassland whiptail & 0 & & $\mathrm{P}, \mathrm{S}$ \\
\hline & & Cnemidophorus sonorae & Sonoran spotted whiptail & 0 & 0 & $\mathrm{P}, \mathrm{S}$ \\
\hline & Colubridae & Masticophis flagellum & coachwhip & & & $\mathrm{P}$ \\
\hline & & Salvadora hexalepis & western patch-nosed snake & $P$ & $S$ & \\
\hline & & Pituophis catenifer & gopher snake & 0 & & 0 \\
\hline & & Rhinocheilus lecontei & long-nosed snake & 0 & & $\mathrm{P}, \mathrm{S}$ \\
\hline & & Tantilla hobartsmithi & southwestern black-headed snake & & & $\mathrm{P}$ \\
\hline & & Hypsiglena torquata & night snake & & $\mathrm{P}$ & $P$ \\
\hline & Elapidae & Micruroides euryxanthus & Sonoran coral snake & & $P$ & \\
\hline & Viperidae & Crotalus atrox & western diamond-backed rattlesnake & 0 & $\mathrm{P}$ & $P$ \\
\hline
\end{tabular}

a "Wildlife of Special Concern"; Arizona Game and Fish Department (HDMS 2004). 
Appendix D. Bird species recorded at Tumacácori NHP by University of Arizona Inventory personnel, 2001-2003, and by personnel working for the Monitoring Avian Productivity and Survivorship Program (MAPS), 1997-2003. Numbers of individuals recorded by Inventory personnel are noted in the "Park unit" columns; numbers are not scaled by search effort and should not to be used for comparison among species. Species in bold-faced type are non-native. Underlining indicates that we obtained a photo voucher. List includes individuals that were observed flying over the park. Park units: "CAL" = Calabazas; "GUV" = Guevavi; "TUM" = Tumacácori.

\begin{tabular}{|c|c|c|c|c|c|c|c|c|}
\hline \multirow[b]{2}{*}{ Order Family } & \multirow[b]{2}{*}{ Scientific name } & \multirow[b]{2}{*}{ Common name } & \multicolumn{3}{|c|}{ Park unita } & \multirow[b]{2}{*}{ MAPSb } & \multirow[b]{2}{*}{$E S A^{c}$} & \multirow{2}{*}{$\begin{array}{l}\text { ESA } \\
\text { date }^{\text {d }}\end{array}$} \\
\hline & & & CAL & GUV & TUM & & & \\
\hline \multicolumn{9}{|l|}{ Anseriformes } \\
\hline \multirow[t]{2}{*}{ Anatidae } & Dendrocygna autumnalis ${ }^{* g}$ & black-bellied whistling duck & 4 & 1 & 1 & $X$ & & \\
\hline & Anas platyrhynchos* & mallard & & & 1 & $\mathrm{X}$ & & \\
\hline \multicolumn{9}{|l|}{ Galliformes } \\
\hline \multirow[t]{2}{*}{ Odontophoridae } & Callipepla gambelii & Gambel's quail & 4 & 10 & 28 & $x$ & & \\
\hline & Cyrtonyx montezumae & Montezuma quail & & & & $x$ & & \\
\hline \multicolumn{9}{|l|}{ Pelicaniformes } \\
\hline \multicolumn{9}{|c|}{ Ciconiiformes } \\
\hline \multirow[t]{4}{*}{ Ardeidae } & Ardea herodias* & great blue heron & & 1 & 9 & $x$ & & \\
\hline & Ardea alba*g & great egret & 2 & 1 & 2 & & & \\
\hline & Egretta thula*g & snowy egret & 1 & & & & & \\
\hline & Nycticorax nycticorax* & black-crowned night-heron & & & 1 & & & \\
\hline Threskiornithidae & Plegadis chihi ${ }^{\star f}$ & white-faced Ibis & & & 2 & $X$ & SC & 1996 \\
\hline \multirow[t]{2}{*}{ Cathartidae } & Coragyps atratus* & black vulture & 2 & & 6 & $\mathrm{X}$ & & \\
\hline & Cathartes aura* & turkey vulture & 1 & & 25 & $X$ & & \\
\hline \multicolumn{9}{|l|}{ Falconiformes } \\
\hline \multirow[t]{5}{*}{ Accipitridae } & Accipiter striatus ${ }^{* f}$ & sharp-shinned hawk & & & 2 & & & \\
\hline & Accipiter cooperii ${ }^{*}$ & Cooper's hawk & & & 17 & $X$ & & \\
\hline & Asturina nitida maxima ${ }^{e, f, g}$ & gray hawk & 2 & 7 & 31 & $B$ & SC & 1996 \\
\hline & Buteo swainsoni ${ }^{*}$ & Swainson's hawk & 1 & & & & & \\
\hline & Buteo jamaicensis* & red-tailed hawk & & 4 & 4 & $X$ & & \\
\hline \multirow[t]{2}{*}{ Falconidae } & Falco sparverius ${ }^{*}$ & American kestrel & & 2 & 1 & & & \\
\hline & Falco peregrinus ${ }^{* f, g, i}$ & peregrine falcon & 1 & & 1 & & SC & 1998 \\
\hline \multicolumn{9}{|l|}{ Charadrifformes } \\
\hline Charadriidae & Charadrius vociferus* & killdeer & 4 & 1 & 1 & $X$ & & \\
\hline \multirow[t]{2}{*}{ Scolopacidae } & Actitis macularia* & spotted sandpiper & & & 1 & & & \\
\hline & Gallinago gallinago* & common snipe & & & 1 & & & \\
\hline \multicolumn{9}{|l|}{ Columbiformes } \\
\hline Columbidae & Columba livia & rock pigeon & & & 1 & $X$ & & \\
\hline & Patagioenas fasciata* & band-tailed pigeon & & & 1 & $X$ & & \\
\hline & Zenaida asiatica* & white-winged dove & 7 & 8 & 109 & $B$ & & \\
\hline & Zenaida macroura* & mourning dove & 36 & 18 & 140 & $B$ & & \\
\hline & Columbina inca & Inca dove & & 2 & 6 & $X$ & & \\
\hline & Columbina passerina & common ground-dove & 6 & 11 & $\underline{22}$ & $B$ & & \\
\hline Cucluliformes & & & & & & & & \\
\hline Cuculidae & $\begin{array}{l}\text { Coccyzus americanus } \\
\text { occidentalis }{ }^{\star}, g, h, i\end{array}$ & yellow-billed cuckoo & 2 & 5 & $\underline{20}$ & $B$ & C & 2002 \\
\hline & Geococcyx californianus & greater roadrunner & 4 & 2 & 8 & $X$ & & \\
\hline Strigiformes & & & & & & & & \\
\hline Tytonidae & Tyto alba & barn owl & & 2 & 2 & & & \\
\hline Strigidae & Megascops kennicottii & western screech-owl & & 2 & 7 & $B$ & & \\
\hline & Bubo virginianus & great horned owl & & & & $X$ & & \\
\hline & Micrathene whitneyi ${ }^{* i}$ & elf owl & & 1 & & $X$ & & \\
\hline Caprimulgiformes & & & & & & & & \\
\hline Caprimulgidae & Chordeiles acutipennis* & lesser nighthawk & & & 2 & $X$ & & \\
\hline Caprimulgidae & Phalaenoptilus nuttallii & common poorwill & & 3 & & & & \\
\hline
\end{tabular}




\begin{tabular}{|c|c|c|c|c|c|c|c|c|}
\hline \multirow[b]{2}{*}{ Order Family } & \multirow[b]{2}{*}{ Scientific name } & \multirow[b]{2}{*}{ Common name } & \multicolumn{3}{|c|}{ Park unita } & \multirow[b]{2}{*}{ MAPS ${ }^{b}$} & \multirow[b]{2}{*}{$\mathrm{ESA}^{\mathrm{c}}$} & \multirow{2}{*}{$\begin{array}{l}\text { ESA } \\
\text { date }^{\mathrm{d}}\end{array}$} \\
\hline & & & CAL & GUV & TUM & & & \\
\hline \multicolumn{9}{|l|}{ Apodiformes } \\
\hline \multirow[t]{2}{*}{ Apodidae } & Chaetura vauxi ${ }^{*}$ & Vaux's swift & & & 1 & $x$ & & \\
\hline & Aeronautes saxatalis* & white-throated swift & & & & $X$ & & \\
\hline \multirow[t]{5}{*}{ Trochilidae } & Cynanthus latirostris* & broad-billed hummingbird & 4 & 1 & $\underline{58}$ & $B$ & & \\
\hline & Archilochus alexandri* & $\begin{array}{l}\text { black-chinned } \\
\text { hummingbird }\end{array}$ & 6 & 1 & $\underline{17}$ & $B$ & & \\
\hline & Calypte anna* & Anna's hummingbird & & & 1 & $x$ & & \\
\hline & Calypte costae ${ }^{*} h$ & Costa's hummingbird & 2 & & & & & \\
\hline & Selasphorus platycercus* & broad-tailed hummingbird & 2 & & 1 & $x$ & & \\
\hline $\begin{array}{c}\text { Trogoniformes } \\
\text { Trogonidae }\end{array}$ & Trogon elegans*g & elegant trogon & & & & $X$ & & \\
\hline \multicolumn{8}{|l|}{ Coraciformes } & \\
\hline \multicolumn{9}{|l|}{ Piciformes } \\
\hline \multirow[t]{6}{*}{ Picidae } & Melanerpes lewis & Lewis's woodpecker & & & 2 & & & \\
\hline & Melanerpes uropygialis ${ }^{i}$ & Gila woodpecker & 15 & 20 & $\underline{167}$ & $B$ & & \\
\hline & Picoides scalaris & ladder-backed woodpecker & 8 & 10 & $\underline{33}$ & $B$ & & \\
\hline & Picoides villosus & hairy woodpecker & & & 1 & & & \\
\hline & Colaptes auratus & northern flicker & 4 & & 19 & $x$ & & \\
\hline & Colaptes chrysoides ${ }^{h, i}$ & gilded flicker & & & 1 & & & \\
\hline \multicolumn{9}{|l|}{ Passeriformes } \\
\hline \multirow[t]{4}{*}{ Tyrannidae } & Camptostoma imberbe* & $\begin{array}{l}\text { northern beardless- } \\
\text { tyrannulet }\end{array}$ & 5 & 3 & 11 & $B$ & & \\
\hline & Contopus cooperi* & olive-sided flycatcher & & & & $X$ & SC & 1996 \\
\hline & Contopus sordidulus* & western wood-pewee & & & 6 & $X$ & & \\
\hline & Empidonax flaviventris* & yellow-bellied flycatcher & & & & $\mathrm{X}$ & & \\
\hline \multirow[t]{19}{*}{ Tyrannidae } & Empidonax trailliii ${ }^{*} g$ & willow flycatcher & & & 3 & X & & \\
\hline & Empidonax traillii traillii ${ }^{\star} f, g, h$ & $\begin{array}{l}\text { southwestern willow } \\
\text { flycatcher }\end{array}$ & & & 1 & & LE & 1995 \\
\hline & Empidonax hammondiï & Hammond's flycatcher & & & 1 & $x$ & & \\
\hline & Empidonax wrightii* & gray flycatcher & & 3 & 1 & & & \\
\hline & Empidonax oberholseri* & dusky flycatcher & & & & $x$ & & \\
\hline & Empidonax difficilis ${ }^{*}$ & pacific-slope flycatcher & & 1 & 1 & $X$ & & \\
\hline & Empidonax occidentalis* & cordilleran flycatcher & & & 1 & $X$ & & \\
\hline & Sayornis nigricans & black phoebe & 1 & 1 & 6 & $X$ & & \\
\hline & Sayornis phoebe* & eastern phoebe & & & 1 & & & \\
\hline & Sayornis saya* & Say's phoebe & 2 & & 25 & & & \\
\hline & Pyrocephalus rubinus* & vermilion flycatcher & 2 & 4 & $\underline{53}$ & $x$ & & \\
\hline & Myiarchus tuberculifer* & dusky-capped flycatcher & & 4 & $\underline{25}$ & $B$ & & \\
\hline & Myiarchus cinerascens* & ash-throated flycatcher & 10 & 7 & $\underline{31}$ & $B$ & & \\
\hline & Myiarchus tyrannulus* & brown-crested flycatcher & 3 & 7 & $\underline{48}$ & $B X$ & & \\
\hline & Myiodynastes luteiventris* & sulphur-bellied flycatcher & & & 1 & $x$ & & \\
\hline & Tyrannus melancholicus ${ }^{g}$ & tropical kingbird & & & & $x$ & & \\
\hline & Tyrannus vociferans* & Cassin's kingbird & 6 & 15 & 36 & $X$ & & \\
\hline & Tyrannus verticalis* & western kingbird & 3 & & 22 & $X$ & & \\
\hline & Pachyramphus aglaiae ${ }^{g}$ & rose-throated becard & & & 1 & $x$ & & \\
\hline \multirow[t]{4}{*}{ Vireonidae } & Vireo bellii* ${ }^{*}, i$ & Bell's vireo & 14 & 9 & $\underline{71}$ & $B$ & & \\
\hline & Vireo plumbeus* & plumbeous vireo & 2 & 1 & 1 & $\mathrm{X}$ & & \\
\hline & Vireo cassinii ${ }^{*}$ & Cassin's vireo & 1 & & & $x$ & & \\
\hline & Vireo gilvus* & warbling vireo & & & $\underline{7}$ & $X$ & & \\
\hline \multirow[t]{3}{*}{ Corvidae } & Aphelocoma californica & western scrub-jay & & & 2 & & & \\
\hline & Corvus sp. & unknown raven & 24 & 5 & 61 & & & \\
\hline & Corvus cryptoleucus & Chihuahuan raven & & & & $X$ & & \\
\hline
\end{tabular}




\begin{tabular}{|c|c|c|c|c|c|c|c|c|}
\hline \multirow[b]{2}{*}{ Order Family } & \multirow[b]{2}{*}{ Scientific name } & \multirow[b]{2}{*}{ Common name } & \multicolumn{3}{|c|}{ Park unita } & \multirow[b]{2}{*}{ MAPS ${ }^{b}$} & \multirow[b]{2}{*}{$\mathrm{ESA}^{\mathrm{c}}$} & \multirow{2}{*}{$\begin{array}{l}\text { ESA } \\
\text { date }^{d}\end{array}$} \\
\hline & & & CAL & GUV & TUM & & & \\
\hline \multicolumn{9}{|l|}{ Passeriformes } \\
\hline Corvidae & Corvus corax & common raven & & & & $x$ & & \\
\hline \multirow[t]{5}{*}{ Hirundinidae } & Tachycineta thalassina* & violet-green swallow & & & 2 & & & \\
\hline & Stelgidopteryx serripennis* & $\begin{array}{l}\text { northern rough-winged } \\
\text { swallow }\end{array}$ & 2 & 5 & 14 & $x$ & & \\
\hline & Riparia riparia* & bank swallow & & & 1 & & & \\
\hline & Petrochelidon pyrrhonota* & cliff swallow & & 3 & 15 & & & \\
\hline & Hirundo rustica* & barn swallow & 4 & 2 & 16 & $x$ & & \\
\hline Paridae & Baeolophus wollweberi & bridled titmouse & & & $\underline{58}$ & $B$ & & \\
\hline Remizidae & Auriparus flaviceps & verdin & 14 & 6 & 70 & $B$ & & \\
\hline Aegithalidae & Psaltriparus minimus & bushtit & & & & $x$ & & \\
\hline Sittidae & Sitta carolinensis & white-breasted nuthatch & & & 3 & $\mathrm{X}$ & & \\
\hline \multirow[t]{4}{*}{ Troglodytidae } & $\begin{array}{l}\text { Campylorhynchus } \\
\text { brunneicapillus }\end{array}$ & cactus wren & & & 1 & $x$ & & \\
\hline & Salpinctes obsoletus & rock wren & 1 & & 1 & & & \\
\hline & Thryomanes bewickii & Bewick's wren & 20 & 18 & $\underline{137}$ & B & & \\
\hline & Troglodytes aedon ${ }^{*}$ & house wren & 1 & & 5 & $x$ & & \\
\hline Regulidae & Regulus calendula* & ruby-crowned kinglet & 1 & 1 & 17 & $x$ & & \\
\hline \multirow[t]{2}{*}{ Sylviidae } & Polioptila caerulea* & blue-gray gnatcatcher & 3 & 1 & 2 & & & \\
\hline & Polioptila melanura & black-tailed gnatcatcher & 3 & 1 & & $x$ & & \\
\hline \multirow[t]{5}{*}{ Turdidae } & Sialia currucoides* & mountain bluebird & & 2 & & & & \\
\hline & Myadestes townsendi* & Townsend's solitaire & 6 & & & & & \\
\hline & Catharus ustulatus ${ }^{*}$ & Swainson's thrush & & & 1 & $x$ & & \\
\hline & Catharus guttatus* & hermit thrush & & & 1 & $X$ & & \\
\hline & Turdus migratorius* & American robin & & & 3 & & & \\
\hline \multirow[t]{5}{*}{ Mimidae } & Dumetella carolinensis ${ }^{*} g$ & gray catbird & & & & $X$ & & \\
\hline & Mimus polyglottos & northern mockingbird & 2 & 3 & 9 & $x$ & & \\
\hline & Toxostoma rufum & brown thrasher & & & & $\mathrm{X}$ & & \\
\hline & Toxostoma curvirostre & curve-billed thrasher & 2 & 3 & 25 & $x$ & & \\
\hline & Toxostoma crissale ${ }^{i}$ & crissal thrasher & & & 1 & $x$ & & \\
\hline Sturnidae & Sturnus vulgaris & European starling & & 1 & 20 & $\mathrm{X}$ & & \\
\hline Motacillidae & Anthus rubescens ${ }^{*}$ & American pipit & & & 1 & & & \\
\hline Bombycillidae & Bombycilla cedrorum* & cedar waxwing & 1 & & 3 & $x$ & & \\
\hline Ptilogonatidae & Phainopepla nitens & phainopepla & 29 & 25 & $\underline{115}$ & $B$ & & \\
\hline \multirow[t]{11}{*}{ Parulidae } & Vermivora celata* & orange-crowned warbler & & & 4 & $x$ & & \\
\hline & Vermivora ruficapilla* & Nashville warbler & & & 1 & $x$ & & \\
\hline & Vermivora virginiae* & Virginia's warbler & & & & $\mathrm{X}$ & & \\
\hline & Vermivora luciae* ${ }^{* h}$ & Lucy's warbler & 28 & 18 & $\underline{107}$ & $B$ & & \\
\hline & Parula americana* & northern parula & & & 1 & & & \\
\hline & Dendroica petechia* & yellow warbler & & 2 & $\underline{46}$ & $B$ & & \\
\hline & Dendroica coronata* & yellow-rumped warbler & 1 & & 9 & & & \\
\hline & Dendroica coronata audubo & Audubon's warbler & & & 10 & $x$ & & \\
\hline & Dendroica nigrescens ${ }^{*}$ & black-throated gray warbler & & & 4 & $x$ & & \\
\hline & Dendroica townsendi* & Townsend's warbler & & & & $x$ & & \\
\hline & Helmitheros vermivorus* & worm-eating warbler & & & & $\underline{x}$ & & \\
\hline \multirow[t]{6}{*}{ Parulidae } & Seiurus aurocapilla* & ovenbird & & & & $\underline{x}$ & & \\
\hline & Seiurus noveboracensis* & northern waterthrush & & & 1 & $x$ & & \\
\hline & Seiurus motacilla* & Louisiana waterthrush & & & & $x$ & & \\
\hline & Oporornis tolmiei* & Macgillivray's warbler & & 2 & 1 & $\mathrm{X}$ & & \\
\hline & Geothlypis trichas* & common yellowthroat & & 1 & $\underline{30}$ & $B$ & & \\
\hline & Wilsonia pusilla* & Wilson's warbler & 3 & & $\underline{11}$ & $x$ & & \\
\hline Parulidae & Icteria virens ${ }^{*}$ & yellow-breasted chat & 13 & 6 & $\underline{144}$ & $B$ & & \\
\hline Thraupidae & Piranga rubra* & summer tanager & 4 & 6 & $\underline{70}$ & $B$ & & \\
\hline
\end{tabular}




\begin{tabular}{|c|c|c|c|c|c|c|c|c|}
\hline \multirow[b]{2}{*}{ Order Family } & \multirow[b]{2}{*}{ Scientific name } & \multirow[b]{2}{*}{ Common name } & \multicolumn{3}{|c|}{ Park unita } & \multirow[b]{2}{*}{ MAPS $^{b}$} & \multirow[b]{2}{*}{$\mathrm{ESA}^{\mathrm{c}}$} & \multirow{2}{*}{$\begin{array}{l}\text { ESA } \\
\text { date }\end{array}$} \\
\hline & & & CAL & GUV & TUM & & & \\
\hline \multicolumn{9}{|l|}{ Passeriformes } \\
\hline Thraupidae & Piranga ludoviciana* & western tanager & 5 & 2 & $\underline{13}$ & $X$ & & \\
\hline \multirow[t]{15}{*}{ Emberizidae } & Pipilo chlorurus* & green-tailed towhee & 4 & & 10 & $x$ & & \\
\hline & Pipilo fuscus & canyon towhee & 3 & 13 & & $X$ & & \\
\hline & Pipilo aberti & Abert's towhee & 3 & 3 & $\underline{30}$ & $B$ & & \\
\hline & Aimophila carpalis ${ }^{*} h, i$ & rufous-winged sparrow & 8 & 10 & $\underline{24}$ & $B$ & & \\
\hline & Aimophila cassinii & Cassin's sparrow & & 3 & & & & \\
\hline & Aimophila ruficeps* & rufous-crowned sparrow & 6 & & & & & \\
\hline & Spizella passerina* & chipping sparrow & 4 & & 37 & & & \\
\hline & Spizella breweri* & Brewer's sparrow & 6 & 2 & 16 & $x$ & & \\
\hline & Chondestes grammacus ${ }^{*}$ & lark sparrow & 6 & 1 & 30 & $X$ & & \\
\hline & Amphispiza bilineata & black-throated sparrow & 24 & 1 & & & & \\
\hline & Melospiza melodia & song sparrow & 3 & 2 & 75 & $B$ & & \\
\hline & Melospiza lincolnii" & Lincoln's sparrow & & & 2 & $x$ & & \\
\hline & Zonotrichia albicollis & white-throated sparrow & & & 1 & & & \\
\hline & Zonotrichia leucophrys* & white-crowned sparrow & 2 & & 41 & $X$ & & \\
\hline & Junco hyemalis & dark-eyed junco & & & 2 & & & \\
\hline \multirow[t]{8}{*}{ Cardinalidae } & Cardinalis cardinalis & northern cardinal & 20 & 7 & $\underline{81}$ & $B$ & & \\
\hline & Cardinalis sinuatus & pyrrhuloxia & 4 & & 4 & $x$ & & \\
\hline & Pheucticus melanocephalus ${ }^{*}$ & black-headed grosbeak & 1 & 2 & 6 & $B$ & & \\
\hline & Passerina caerulea* & blue grosbeak & 17 & & $\underline{17}$ & $B$ & & \\
\hline & Passerina amoena* & lazuli bunting & 7 & 5 & 6 & $X$ & & \\
\hline & Passerina cyanea* & indigo bunting & & & $\underline{3}$ & $x$ & & \\
\hline & Passerina versicolor* & varied bunting & 3 & 1 & $\underline{6}$ & $B$ & & \\
\hline & Passerina ciris* & painted bunting & & 2 & & $\underline{x}$ & & \\
\hline \multirow[t]{9}{*}{ Icteridae } & Agelaius phoeniceus* & red-winged blackbird & 2 & 1 & & $x$ & & \\
\hline & $\begin{array}{l}\text { Xanthocephalus } \\
\text { xanthocephalus }\end{array}$ & yellow-headed blackbird & & & & $x$ & & \\
\hline & Euphagus cyanocephalus* & Brewer's blackbird & 1 & 4 & & & & \\
\hline & Quiscalus mexicanus & great-tailed grackle & 1 & 2 & 40 & $x$ & & \\
\hline & Molothrus aeneus* & bronzed cowbird & & & $\underline{4}$ & $x$ & & \\
\hline & Molothrus ater & brown-headed cowbird & 15 & 8 & $\underline{114}$ & $B$ & & \\
\hline & Icterus cucullatus* & hooded oriole & 3 & & $\underline{9}$ & $B$ & & \\
\hline & Icterus bullockii* & Bullock's oriole & 5 & 2 & 11 & $x$ & & \\
\hline & Icterus parisorum ${ }^{*}$ & Scott's oriole & & & & $X$ & & \\
\hline \multirow[t]{2}{*}{ Fringillidae } & Carpodacus mexicanus & house finch & 11 & 14 & 65 & $\mathrm{~B}$ & & \\
\hline & Carduelis psaltria* & lesser goldfinch & 9 & 9 & 122 & $B$ & & \\
\hline Passeridae & Passer domesticus & house sparrow & & & 110 & 0 & & \\
\hline Species richness & & & 80 & 74 & 129 & 126 & & \\
\hline
\end{tabular}

${ }^{*}$ Neotropical migrant (Rappole 1995).

a Number of birds recorded by all survey methods.

${ }^{b}$ MAPS = Monitoring Avian Productivity and Survivorship mist-netting program: $X=$ detected 1997-2003, B = evidence of breeding in 2003 (Turner 2003).

" ESA = Endangered Species Act: LE = "Listed Endangered", C = "Candidate", SC = "Species of Concern"; U.S. Fish and Wildlife Service (HDMS 2004).

d ESA date = year of listing in Endangered Species Act.

e "Sensitive species"; Bureau of Land Management (HDMS 2004).

f "Sensitive species"; U.S.D.A. Forest Service (HDMS 2004).

g "Wildlife of Special Concern"; Arizona Game and Fish Department (HDMS 2004).

h "Priority species"; Arizona Partners in Flight (Latta et al. 1999).

i "Species of conservation concern”; U.S. Fish and Wildlife Service (HDMS 2004). 
Appendix E. Mammal species observed or documented by University of Arizona Inventory personnel or were found in museum collections (Appendix 0), Tumacácori NHP, 2001-2002. Species in bold-faced type are non-native. Park units: "CAL" = Calabazas; "GUV" = Guevavi; "TUM" = Tumacácori.

\begin{tabular}{|c|c|c|c|c|c|c|c|}
\hline \multirow[b]{2}{*}{ Order } & \multirow[b]{2}{*}{ Family } & \multirow[b]{2}{*}{ Scientific name } & \multirow[b]{2}{*}{ Common name } & \multicolumn{3}{|c|}{ Park unit } & \multirow{2}{*}{$\begin{array}{c}\text { Appendix } \\
0\end{array}$} \\
\hline & & & & CAL & GUV & TUM & \\
\hline \multirow[t]{5}{*}{ Chiroptera } & Phyllostomidae & Mactrotis californicus & California leaf-nosed bat & & & & $X$ \\
\hline & Vespertilionidae & Antrozous pallidus & pallid bat & & & $\mathrm{X}$ & $X$ \\
\hline & & Myotis velifer & cave myotis & & & & $\mathrm{X}$ \\
\hline & & Myotis californicus & California myotis & & & & $X$ \\
\hline & Molossidae & Tadarida brasiensis & Brazilian free-tailed bat & & & & $X$ \\
\hline Didelphimorphia & Didelphidae & Didelphis virginiana & Virginia opossum & & & $\mathrm{X}$ & \\
\hline Insectivora & Sorcidae & Notiosorex sp. & unknown desert shrew & $x$ & & $X$ & \\
\hline \multirow[t]{10}{*}{ Carnivora } & Ursidae & Ursus americanus & American black bear & & & $\mathrm{X}$ & \\
\hline & Procyonidae & Procyon lotor & northern raccoon & & & X & \\
\hline & Mephitidae & Spilogale gracilis & western spotted skunk & & & $\mathrm{X}$ & \\
\hline & & Mephitis mephitis & striped skunk & & & $\mathrm{X}$ & \\
\hline & & Mephitis macroura & hooded skunk & & & $\mathrm{X}$ & \\
\hline & & Conepatus leuconotus & white-backed hog-nosed skunk & & & $x$ & \\
\hline & Canidae & Canis familiaris & domestic dog & & & $x$ & \\
\hline & & Canis latrans & coyote & & & $x$ & \\
\hline & Felidae & Felis catus & domestic cat & & & $\mathrm{X}$ & \\
\hline & & Lynx rufus & bobcat & & & $\mathrm{X}$ & \\
\hline \multirow[t]{17}{*}{ Rodentia } & Geomyidae & Thomomys bottae & Botta's pocket gopher & & & $\mathrm{X}$ & \\
\hline & Heteromyidae & Chaetodipus penicillatus & Sonoran desert pocket mouse & $x$ & $\mathrm{X}$ & $\mathrm{X}$ & \\
\hline & & Chaetodipus baileyi & Bailey's pocket mouse & $x$ & $x$ & & \\
\hline & Muridae & Reithrodontomys megalotis a & western harvest mouse & & & $\mathrm{X}$ & \\
\hline & & Reithrodontomys fulvescens & fulvous harvest mouse & $X$ & $X$ & $\mathrm{X}$ & \\
\hline & & Peromyscus eremicus eremicus $a, b$ & cactus mouse & $x$ & $X$ & $x$ & \\
\hline & & Peromyscus maniculatus & deer mouse & $x$ & & $\mathrm{X}$ & \\
\hline & & Peromyscus leucopus & white-footed mouse & $x$ & & $x$ & \\
\hline & & Peromyscus boylii & brush mouse & & $\mathrm{X}$ & & \\
\hline & & Baiomys taylori & northern pygmy mouse & & $X$ & & \\
\hline & & Onychomys leucogaster & northern grasshopper mouse & & $X$ & & \\
\hline & & Onychomys torridus & southern grasshopper mouse & $x$ & $X$ & $\mathrm{x}$ & \\
\hline & & Neotoma albigula & western white-throated woodrat & $x$ & $x$ & $X$ & \\
\hline & & Sigmodon fulviventer & tawny-belled cotton rat & $x$ & & & \\
\hline & & Sigmodon ochrognathus ${ }^{\text {a }}$ & yellow-nosed cotton rat & $x$ & & & \\
\hline & & Sigmodon arizonae arizonae & Arizona cotton rat & $x$ & & $x$ & \\
\hline & & Mus musculus & house mouse & $x$ & & $\mathrm{X}$ & \\
\hline Lagomorpha & Leporidae & Sylvilagus species & unknown cottontail & $x$ & & $\mathrm{X}$ & \\
\hline \multirow[t]{5}{*}{ Artiodactyla } & Bovidae & Bos taurus & domestic cow & & & $x$ & \\
\hline & Tayassuidae & Pecari tajacu & collard peccary & & & $x$ & \\
\hline & Cervidae & Odocoileus species & unknown deer & & $X$ & & \\
\hline & & Odocoileus hemionus & mule deer & $X$ & & & \\
\hline & & Odocoileus virginianus & white-tailed deer & & & $x$ & $x$ \\
\hline
\end{tabular}

\footnotetext{
a "Species of Concern"; U.S. Fish and Wildlife Service. ESA date for all species: 28 February 1996 (HDMS 2004).

b "Sensitive species"; U.S.D.A. Forest Service (HDMS 2004).
} 
Appendix F. Plant species recorded at the Tumacácori unit by previous researchers but not recorded by University of Arizona Inventory personnel, Tumacácori NHP. Species in bold-faced type are non-native.

\begin{tabular}{|c|c|c|c|c|c|}
\hline Family & Scientific name & Common name & Moatta & Bennett ${ }^{b}$ & $U^{c}$ \\
\hline \multirow[t]{3}{*}{ Amaranthaceae } & Alternanthera pungens Kunth & creeping chaffweed & $\mathrm{X}$ & & \\
\hline & Amaranthus arenicola I.M. Johnston & sandhill amaranth & & $\mathrm{X}$ & \\
\hline & $\begin{array}{l}\text { Amaranthus fimbriatus var. denticulatus (Torr.) Uline \& } \\
\text { Bray }\end{array}$ & fringed amaranth & & $\mathrm{X}$ & \\
\hline Anacardiaceae & Rhus trilobata var. anisophylla (Greene) Jepson & skunkbush sumac & & $\mathrm{X}$ & \\
\hline \multirow[t]{8}{*}{ Asteraceae } & Ambrosia cordifolia (Gray) Payne & heartleaf bursage & & $\mathrm{X}$ & \\
\hline & Ambrosia psilostachya DC. & Cuman ragweed & $\mathrm{X}$ & $X$ & \\
\hline & Bidens frondosa $\mathrm{L}$. & bur marigold & & $X$ & \\
\hline & Bidens pilosa L. & beggar's tick & & $\mathrm{X}$ & \\
\hline & Dyssodia papposa (Vent.) A.S. Hitchc. & dogbane dyssodia & $\mathrm{X}$ & & \\
\hline & Machaeranthera tanacetifolia (Kunth) Nees & tanseyleaf aster & $\mathrm{X}$ & & \\
\hline & Sonchus oleraceus L. & common sowthistle & & & $\mathrm{X}$ \\
\hline & Verbesina encelioides (Cav.) Benth. \& Hook f. ex Gray & golden crownbeard & $\mathrm{X}$ & $\mathrm{X}$ & $\mathrm{X}$ \\
\hline \multirow[t]{2}{*}{ Capparaceae } & Cleome lutea var. jonesii J.F. Macbr. & Jones spiderflower & & $\mathrm{X}$ & $\mathrm{X}$ \\
\hline & $\begin{array}{l}\text { Polanisia dodecandra spp. trachysperma (Torr. \& } \\
\text { Gray) Iltis }\end{array}$ & clammyweed & $\mathrm{X}$ & $\mathrm{X}$ & \\
\hline Caprifoliaceae & Lonicera interrupta Benth. & chaparral honeysuckle & & $\mathrm{X}$ & \\
\hline \multirow[t]{4}{*}{ Chenopodiaceae } & Chenopodium dessicatum A. Nels. & arid goosefoot & $\mathrm{X}$ & & \\
\hline & Chenopodium fremontii var. fremontii S. Wats. & Fremont goosefoot & & $\mathrm{X}$ & \\
\hline & Chenopodium incanum (S. Wats.) Heller & mealy goosefoot & & & $\mathrm{X}$ \\
\hline & Chenopodium leptophyllum (Moq.) Nutt. ex S. Wats. & narrowleaf goosefoot & & $\mathrm{X}$ & \\
\hline Commelinaceae & Commelina erecta $\mathrm{L}$. & erect dayflower & $\mathrm{X}$ & & \\
\hline \multirow{2}{*}{ Convolvulaceae } & Ipomoea purpurea (L.) Roth & common morningglory & $\mathrm{X}$ & $\mathrm{X}$ & \\
\hline & Ipomoea ternifolia var. leptotoma (Torr.) J.A. McDonald & pink morningglory & & & $X$ \\
\hline Cuscutaceae & Cuscuta indecora var. indecora Choisy & bigseed alfalfa dodder & & $\mathrm{X}$ & \\
\hline Cyperaceae & Cyperus esculentus $L$. & chufa & & $X$ & \\
\hline \multirow[t]{3}{*}{ Euphorbiaceae } & Chamaesyce abramsiana (L.C. Wheeler) Koutnik & Abram's spurge & & & $\mathrm{X}$ \\
\hline & Chamaesyce prostrata (Ait.) Small & prostrate sandmat & $\mathrm{X}$ & $\mathrm{X}$ & \\
\hline & Chamaesyce serpyllifolia ssp. serpyllifolia (Pers.) Small & thyme-leaf sandmat & $\mathrm{X}$ & & \\
\hline \multirow[t]{2}{*}{ Fabaceae } & Parkinsonia microphylla Torr. & littleleaf palo verde & & $\mathrm{X}$ & \\
\hline & Sphinctospermum constrictum (S. Wats.) Rose & hourglass peaseed & & & $\mathrm{X}$ \\
\hline Myrtaceae & Myrtus communis L. & myrtle & $\mathrm{X}$ & & \\
\hline Nyctaginaceae & Boerhavia coulteri (Hook. f.) S. Wats. & Coulter spiderling & $\mathrm{X}$ & $\mathrm{X}$ & $X$ \\
\hline Oleaceae & Ligustrum japonicum Thunb. & Japanese privet & $\mathrm{X}$ & & \\
\hline \multirow[t]{7}{*}{ Poaceae } & Bouteloua chondrosioides (Kunth) Benth. Ex S. Wats. & sprucetop grama & & & X \\
\hline & Bromus tectorum L. & cheat grass & & $\mathrm{X}$ & \\
\hline & $\begin{array}{l}\text { Eragrostis pectinacae var. pectinacea (Michx.) Nees } \\
\text { ex Steud. }\end{array}$ & purple love grass & $\mathrm{X}$ & & \\
\hline & Muhlenbergia filiformis (Thurb. ex S. Wats.) Rydb. & pullup muhly & & $\mathrm{X}$ & \\
\hline & Muhlenbergia porteri Scribn. ex Beal & bush muhly & $\mathrm{X}$ & $\mathrm{X}$ & $X$ \\
\hline & Sporobolus contractus A.S. Hitchc. & spike dropseed & $\mathrm{X}$ & & \\
\hline & Sporobolus wrightii Munro ex Scribn. & big sacaton & $\mathrm{X}$ & & \\
\hline Portulacaceae & $\begin{array}{l}\text { Portulaca umbraticola ssp. coronata (Small) Matthews } \\
\& \text { Ketron }\end{array}$ & wingpod purslane & $\mathrm{X}$ & & \\
\hline \multirow[t]{2}{*}{ Rosaceae } & Pyracantha fortuneana (Maxim.) Li & Chinese firethorn & $x$ & & \\
\hline & Rubus arizonensis Focke & Arizona blackberry & & $\mathrm{X}$ & \\
\hline \multirow[t]{3}{*}{ Solanaceae } & Lycium berlandieri Dunal & berlandier wolfberry & $\mathrm{X}$ & & \\
\hline & Solanum douglasii Dunal & green-spot nightshade & & $\mathrm{X}$ & \\
\hline & Solanum lycopersicum var. lycopersicum L. & garden tomato & $\mathrm{X}$ & & \\
\hline Zygophyllaceae & Kallstroemia grandiflora Torr. ex Gray & Arizona poppy & $\mathrm{X}$ & $X$ & \\
\hline
\end{tabular}




\section{Appendix G. Amphibian and reptile species that were not recorded by University of Arizona Inventory personnel but that may occur at Tumacácori NHP based on documentation in the area by other researchers, or based on published range maps. Species in boldface-type are non-native.}

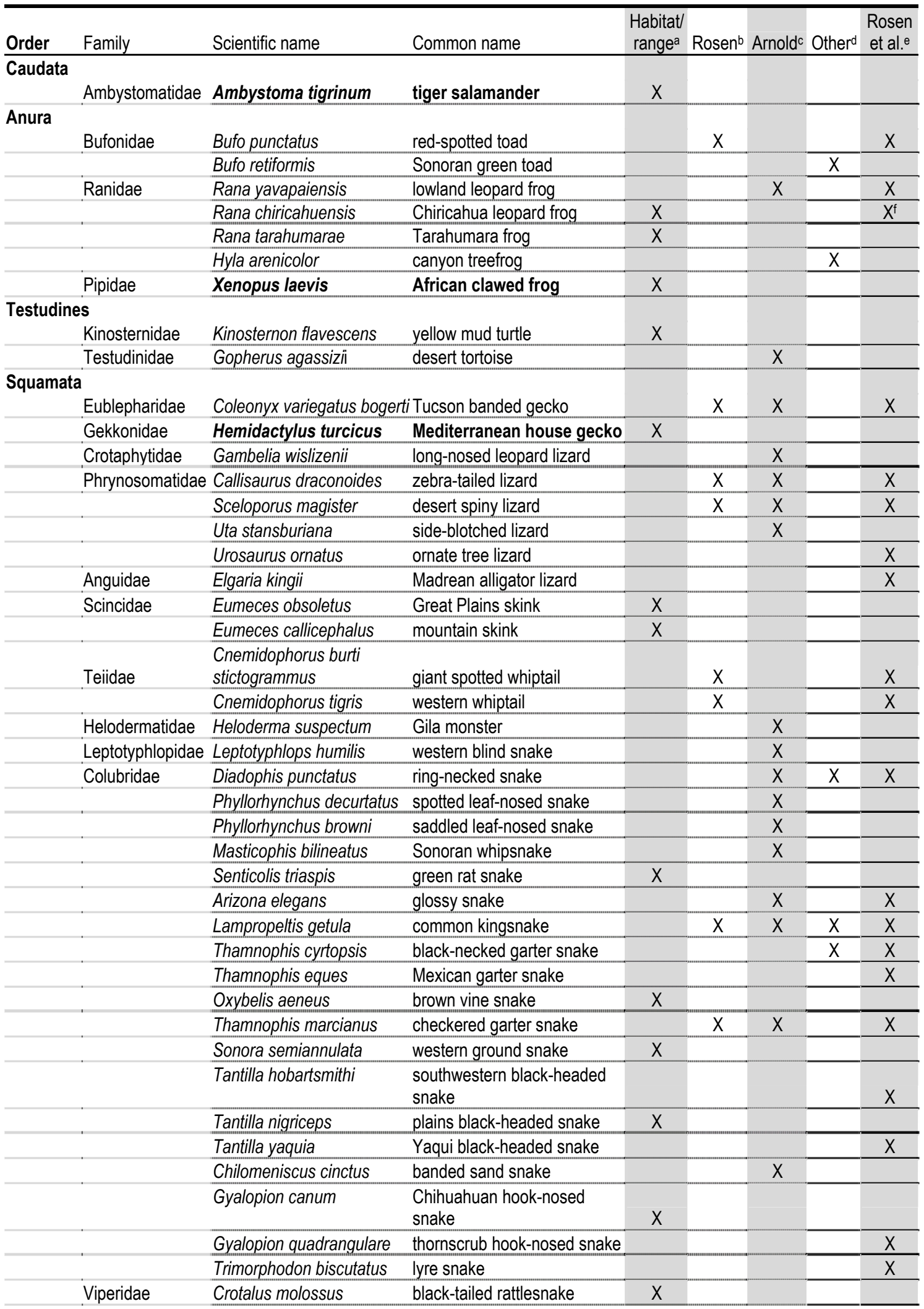




\begin{tabular}{|c|c|c|c|c|c|c|c|}
\hline Family & Scientific name & Common name & $\begin{array}{l}\text { Habitat/ } \\
\text { range }^{a}\end{array}$ & Rosen $^{b}$ & Arnoldc & Other ${ }^{d}$ & $\begin{array}{l}\text { Rosen } \\
\text { et al.e }\end{array}$ \\
\hline \multirow[t]{2}{*}{ Squamata Viperidae } & Crotalus tigris & tiger rattlesnake & $\mathrm{X}$ & & & & \\
\hline & Crotalus scutulatus & Mohave rattlesnake & & & $x$ & & $X$ \\
\hline Iguanidae & Ctenosaura hemilopha & $\begin{array}{l}\text { Baja California spiny-tailed } \\
\text { iguana }\end{array}$ & & & & & $\mathrm{X}$ \\
\hline
\end{tabular}

a Within geographic range, and with habitat associations present as described in Stebbins (2003), listed if not listed by another source.

${ }^{b}$ Recorded by Rosen and Mauz (2000) or by Rosen (pers. comm.).

${ }^{c}$ Recorded by Arnold (1940) $\sim 60 \mathrm{~km}$ north of Tumacácori NHP.

d Sightings by park personnel or reliable volunteers at Tumacácori NHP, or recorded by Drost (1998).

e Found in the Rosen et al. (2004) survey of museum records from the Nogales area of the Santa Cruz River.

f Possibly Rana chiricahuensis; recorded as Rana pipiens complex. 
Appendix H. Bird species that were not recorded by University of Arizona Inventory personnel but that may occur at Tumacácori NHP. Data are from Davis and Russell (1999). Observations at the park by other researchers/observers are indicated in the "Notes" column. Species on this list are those that are most likely; we do not include species that are considered "accidental" (species with few observations in southern Arizona).

\begin{tabular}{|c|c|c|c|c|}
\hline \multirow[b]{2}{*}{ Scientific name } & \multirow[b]{2}{*}{ Common name } & \multicolumn{2}{|c|}{ Habitat/Range } & \multirow[b]{2}{*}{ Notes } \\
\hline & & Winter & Summer & \\
\hline Butorides virescens & green heron & $\mathrm{X}$ & $\mathrm{X}$ & $\begin{array}{l}\text { Breeds along permanent streams (e.g., Sonoita } \\
\text { Creek) }\end{array}$ \\
\hline Aix sponsa & wood duck & $\mathrm{X}$ & & Riparian areas - water \\
\hline Anas crecca & green-winged teal & $\mathrm{X}$ & & Riparian areas- water \\
\hline Circus cyaneus & northern harrier & $\mathrm{X}$ & & Common in agricultural areas \\
\hline Buteo regalis & ferruginous hawk & $\mathrm{X}$ & & Agricultural areas \\
\hline Buteo lagopus & rough-legged hawk & $\mathrm{X}$ & & Agricultural areas \\
\hline Buteo albonatatus & zone-tailed hawk & $\mathrm{X}$ & $\mathrm{X}$ & $\begin{array}{l}\text { All areas; voucher specimen from the park; see } \\
\text { Appendix } 0\end{array}$ \\
\hline Aquila chrysaetos & golden eagle & $\mathrm{X}$ & $\mathrm{X}$ & Open areas \\
\hline Falco columbarius & merlin & $\mathrm{X}$ & & All communities \\
\hline Falco mexicanus & prairie falcon & $\mathrm{X}$ & $\mathrm{X}$ & Open grasslands \\
\hline Callipepla squamata & scaled quail & $\mathrm{X}$ & $\mathrm{X}$ & Semidesert grasslands \\
\hline "Charadrius vociferus & killdeer & $\mathrm{X}$ & X & Agricultural fields; seen by Larry Norris April 2003 \\
\hline Charadrius montanus & mountain plover & $\mathrm{X}$ & & Agricultural fields \\
\hline Columbina talpacoti & ruddy ground-dove & $\mathrm{X}$ & $\mathrm{X}$ & $\begin{array}{l}\text { Open areas/ mesquite bosque; seen by Larry Norris } \\
\text { August } 2002\end{array}$ \\
\hline Asio otus & long-eared owl & $\bar{X}$ & $\mathrm{X}$ & $\begin{array}{l}\text { Summer resident in dense bosque and adjacent } \\
\text { agricultural fields }\end{array}$ \\
\hline Aegolius acadicus & northern saw-whet owl & $\mathrm{X}$ & & Riparian areas \\
\hline Amazilia violiceps & $\begin{array}{l}\text { violet-crowned } \\
\text { hummingbird }\end{array}$ & & $\mathrm{X}$ & Riparian woodlands \\
\hline Selasphorus rufus & rufous hummingbird & $X$ & $\mathrm{X}$ & $\begin{array}{l}\text { All areas; Seen by Susan Wethington in March, July, } \\
\text { August, September and October } 2003\end{array}$ \\
\hline Ceryle alcyon & belted kingfisher & $\mathrm{X}$ & & Riparian areas-water \\
\hline Sphyrapicus nuchalis & red-naped sapsucker & $\bar{x}$ & & Riparian areas \\
\hline Contopus pertinax & greater pewee & $\mathrm{X}$ & & Riparian area/mesquite bosque \\
\hline Pachyramphus aglaiae & rose-throated becard & $\mathrm{X}$ & $X$ & $\begin{array}{l}\text { Riparian areas; seen by Larry Norris (July 2002) and } \\
\text { Barry Zimmer (February 2004) }\end{array}$ \\
\hline Lanius ludovicianus & loggerhead shrike & $\mathrm{X}$ & $\mathrm{X}$ & $\begin{array}{l}\text { Semidesert grasslands; specimen voucher from the } \\
\text { park; see Appendix } 0\end{array}$ \\
\hline Vireo huttoni & Hutton's vireo & $\mathrm{X}$ & & Riparian areas; seen by Larry Norris June 2001 \\
\hline Vireo gilvus & warbling vireo & $\mathrm{X}$ & & Riparian areas; seen by Larry Norris April 2002 \\
\hline Eremophila alpestris & horned lark & $\mathrm{X}$ & $X$ & Agricultural fields \\
\hline Tachycineta bicolor & tree swallow & $\mathrm{X}$ & & All areas \\
\hline Certhia Americana & brown creeper & $\mathrm{X}$ & & Riparian areas \\
\hline Catherpes mexicanus & canyon wren & $\mathrm{X}$ & & Semidesert grasslands \\
\hline Cistothorus palustris & marsh wren & $\bar{X}$ & & Riparian areas- adjacent to water \\
\hline Sialia mexicana & western bluebird & $\mathrm{X}$ & & Semidesert grasslands \\
\hline Ixoreus naevius & varied thrush & $\mathrm{X}$ & & \\
\hline Pipilo maculates & spotted towhee & $\mathrm{X}$ & & Dense vegetation \\
\hline Aimophila botterii & Botteri's sparrow & & $\mathrm{X}$ & Semidesert grasslands \\
\hline Pooecetes gramineus & vesper sparrow & $\mathrm{X}$ & & $\begin{array}{l}\text { Agricultural fields/ mesquite bosque edge; seen by } \\
\text { Larry Norris April } 2002\end{array}$ \\
\hline Calamospiza melanocorys & lark bunting & $\mathrm{X}$ & & Fallow fields \\
\hline Passerculus sandwichensis & savannah sparrow & $\mathrm{X}$ & & Fields \\
\hline Passerella iliaca & fox sparrow & $\mathrm{X}$ & & Riparian woodlands \\
\hline Melospiza georgiana & swamp sparrow & $\mathrm{X}$ & & Riparian woodlands \\
\hline Zonotrichia atricapilla & golden-crowned sparrow & $\mathrm{X}$ & & Semidesert grasslands \\
\hline Calcarius ornatus & $\begin{array}{l}\text { chestnut-collared } \\
\text { longspur }\end{array}$ & $X$ & & Open areas \\
\hline Sturnella magna & eastern meadowlark & $\bar{x}$ & $\mathrm{X}$ & Semidesert grasslands \\
\hline Sturnella neglecta & western meadowlark & $\mathrm{X}$ & & Semidesert grasslands \\
\hline
\end{tabular}




\begin{tabular}{llll}
\hline \multirow{2}{*}{ Scientific name } & Common name & \multicolumn{2}{c}{ Habitat/Range } \\
\cline { 2 - 3 } & Winter & Summer & Notes \\
\hline Carpodacus cassinii & Cassin's finch & $\mathrm{X}$ & All areas-feeders \\
\hline Carduelis pinus & pine siskin & $\mathrm{X}$ & All areas-feeders \\
\hline Carduelis lawrencei & Lawrence's goldfinch & $\mathrm{X}$ & All areas-feeders \\
\hline Carduelis tristis & American goldfinch & $\mathrm{X}$ & All areas-feeders \\
\hline
\end{tabular}




\section{Appendix I. Mammal species that were not recorded by University of Arizona Inventory personnel or}

were found in museum collections (Appendix 0), but that may occur at Tumacácori NHP.

\begin{tabular}{|c|c|c|c|c|c|}
\hline & \multirow[b]{2}{*}{ Family } & \multirow[b]{2}{*}{ Scientific name } & \multirow[b]{2}{*}{ Common name } & \multicolumn{2}{|c|}{ Habitat/Range } \\
\hline & & & & $\begin{array}{c}\text { Burt and } \\
\text { Grossenheider } \\
(1976)\end{array}$ & $\begin{array}{c}\text { Hoffmeister } \\
(1986)\end{array}$ \\
\hline \multirow[t]{2}{*}{ Insectivora } & Sorcidae & Notiosorex crawfordi & Crawford's desert shrew & $x$ & $X$ \\
\hline & & Notiosorex cockrumi & Cockrum's desert shrew & & $X$ \\
\hline \multirow[t]{18}{*}{ Chiroptera } & Phyllostomidae & Choeronycteris mexicana & Mexican long-tongue bat & $X$ & $X$ \\
\hline & & Leptonycteris curasoae & southern long-nosed bat & $X$ & $x$ \\
\hline & Vespertilionidae & Myotis occultus & Arizona myotis & $X$ & \\
\hline & & Myotis yumanensis & Yuma myotis & $X$ & \\
\hline & & Myotis auriculus & southern myotis & & $X$ \\
\hline & & Myotis thysanodes & fringed myotis & $X$ & $x$ \\
\hline & & Myotis volans & long-legged myotis & $x$ & $x$ \\
\hline & & Myotis cilioabrum & western small-footed myotis & $X$ & $X$ \\
\hline & & Lasionycteris noctivagans & silver-haired bat & $X$ & \\
\hline & & Pipistrellus hesperus & western pipistrelle & $X$ & $X$ \\
\hline & & Eptesicus fuscus & big brown bat & $X$ & $X$ \\
\hline & & Lasiurus blossevillii & western red bat & $X$ & $X$ \\
\hline & & Lasiurus cinereus & hoary bat & $X$ & $X$ \\
\hline & & Lasiurus xanthinus & western yellow bat & $X$ & $X$ \\
\hline & & Corynorhinus townsendii & Townsend's big eared bat & $x$ & $X$ \\
\hline & Molossidae & Nyctinomops femorosaccus & pocketed free-tailed bat & $X$ & $X$ \\
\hline & & Nyctinomops macrotis & big free-tailed bat & $X$ & \\
\hline & & Eumops perotis & western bonneted bat & $X$ & $X$ \\
\hline \multirow[t]{7}{*}{ Carnivora } & Procyonidae & Nasua narica & white-nosed coati & $x$ & $X$ \\
\hline & & Bassariscus astutus & ringtail & $X$ & $X$ \\
\hline & Mustelidae & Taxidea taxus & American badger & $X$ & \\
\hline & Canidae & Urocyon cinereoargenteus & common gray fox & $X$ & $X$ \\
\hline & & Vulpes macrotis & kit fox & $x$ & $X$ \\
\hline & Felidae & Panthera onca & jaguar & $X$ & $X$ \\
\hline & & Puma concolor & mountain lion & $X$ & $X$ \\
\hline \multirow[t]{17}{*}{ Rodentia } & Sciuridae & Spermophilus variegatus & rock squirrel & $X$ & $X$ \\
\hline & & Spermophilus spilosoma & spotted ground squirrel & $X$ & $X$ \\
\hline & & Spermophilus tereticaudus & round-tailed ground squirrel & $X$ & $X$ \\
\hline & & Ammospermophilus harrisii & Harris' antelope squirrel & $X$ & $X$ \\
\hline & Geomyidae & Thomomys bottae & Botta's pocket gopher & $X$ & $X$ \\
\hline & Heteromyidae & Perognathus flavus & silky pocket mouse & $X$ & $X$ \\
\hline & & Perognathus amplus & Arizona pocket mouse & $X$ & $x$ \\
\hline & & Chaetodipus intermedius & rock pocket mouse & $X$ & $X$ \\
\hline & & Chaetodipus hispidus & hispid pocket mouse & $X$ & $X$ \\
\hline & & Dipodomys spectabilis & banner-tailed kangaroo rat & $x$ & $X$ \\
\hline & & Dipodomys ordii & Ord's kangaroo rat & $X$ & $X$ \\
\hline & & Dipodomys merriami & Merriam's kangaroo rat & $X$ & $X$ \\
\hline & Castoridae & Castor canadensis & American beaver & $x$ & \\
\hline & Muridae & Reithrodontomys megalotis & western harvest mouse & $X$ & $X$ \\
\hline & & Peromyscus merriami & Merriam's mouse & $X$ & $X$ \\
\hline & & Sigmodon hispidus & hispid cotton rat & $X$ & $X$ \\
\hline & & Sigmodon ochrognathus & yellow-nosed cotton rat & $X$ & $X$ \\
\hline \multirow{4}{*}{\multicolumn{2}{|c|}{ Lagomorpha Leporidae }} & Lepus alleni & antelope jackrabbit & $X$ & $X$ \\
\hline & & Lepus californicus & black-tailed jackrabbit & $X$ & $X$ \\
\hline & & Sylvilagus floridanus & eastern cottontail & $X$ & $X$ \\
\hline & & Sylvilagus audubonii & desert cottontail & $X$ & $X$ \\
\hline
\end{tabular}


Appendix J. UTM coordinates (NAD 83) of vegetation (modular) survey plots at the Tumacácori Unit, Tumacácori NHP, 2002. Accuracy is $\pm 1 \mathrm{~m}$.

\begin{tabular}{|c|c|c|c|}
\hline $\begin{array}{l}\text { Plot } \\
\text { name }\end{array}$ & Corner & Easting & Northing \\
\hline \multirow[t]{4}{*}{1} & $\mathrm{NE}$ & 495298 & 3493558 \\
\hline & NW & 495276 & 3493563 \\
\hline & SE & 495292 & 3493539 \\
\hline & SW & 495272 & 3493543 \\
\hline \multirow[t]{4}{*}{4} & $\mathrm{NE}$ & 495199 & 3493369 \\
\hline & NW & 495180 & 3493372 \\
\hline & SE & 495195 & 3493349 \\
\hline & SW & 495176 & 3493353 \\
\hline \multirow[t]{4}{*}{6} & $\mathrm{NE}$ & 495317 & 3493717 \\
\hline & NW & 495299 & 3493718 \\
\hline & SE & 495315 & 3493696 \\
\hline & SW & 495296 & 3493699 \\
\hline \multirow[t]{4}{*}{8} & $\mathrm{NE}$ & 495700 & 3492806 \\
\hline & NW & 495678 & 3492812 \\
\hline & SE & 495690 & 3492785 \\
\hline & SW & 495675 & 3492788 \\
\hline \multirow[t]{4}{*}{9} & $\mathrm{NE}$ & 495577 & 3493069 \\
\hline & NW & 495556 & 3493078 \\
\hline & SE & 495573 & 3493052 \\
\hline & SW & 495552 & 3493057 \\
\hline \multirow[t]{4}{*}{13} & $\mathrm{NE}$ & 495208 & 3493049 \\
\hline & NW & 495189 & 3493051 \\
\hline & SE & 495206 & 3493029 \\
\hline & SW & 495184 & 3493033 \\
\hline \multirow[t]{4}{*}{16} & $\mathrm{NE}$ & 495350 & 3493445 \\
\hline & NW & 495333 & 3493444 \\
\hline & SE & 495349 & 3493421 \\
\hline & SW & 495326 & 3493428 \\
\hline \multirow[t]{4}{*}{18} & $\mathrm{NE}$ & 495322 & 3494018 \\
\hline & NW & 495302 & 3494021 \\
\hline & SE & 495317 & 3493997 \\
\hline & SW & 495298 & 3494001 \\
\hline $21 \mathrm{~A}$ & NW & 495369 & 3493592 \\
\hline \multirow[t]{4}{*}{$24 \mathrm{~A}$} & $\mathrm{NE}$ & 495608 & 3491984 \\
\hline & NW & 495586 & 3491989 \\
\hline & SE & 495606 & 3491964 \\
\hline & SW & 495588 & 3491971 \\
\hline \multirow[t]{2}{*}{29} & $\mathrm{NE}$ & 495643 & 3492937 \\
\hline & NW & 495623 & 3492940 \\
\hline
\end{tabular}

\begin{tabular}{|c|c|c|c|}
\hline $\begin{array}{l}\text { Plot } \\
\text { name }\end{array}$ & Corner & Easting & Northing \\
\hline \multirow[t]{2}{*}{29} & SE & 495637 & 3492916 \\
\hline & SW & 495618 & 3492921 \\
\hline \multirow[t]{4}{*}{$30 \mathrm{~A}$} & $\mathrm{NE}$ & 495734 & 3493032 \\
\hline & NW & 495717 & 3493034 \\
\hline & SE & 495729 & 3493012 \\
\hline & SW & 495712 & 3493018 \\
\hline \multirow[t]{4}{*}{$31 \mathrm{~A}$} & $\mathrm{NE}$ & 495263 & 3494365 \\
\hline & NW & 495247 & 3494369 \\
\hline & SE & 495259 & 3494345 \\
\hline & SW & 495237 & 3494351 \\
\hline \multirow[t]{4}{*}{$32 \mathrm{~A}$} & $\mathrm{NE}$ & 495637 & 3492544 \\
\hline & NW & 495617 & 3492548 \\
\hline & SE & 495632 & 3492525 \\
\hline & SW & 495614 & 3492528 \\
\hline \multirow[t]{4}{*}{35} & $\mathrm{NE}$ & 495573 & 3493566 \\
\hline & NW & 495554 & 3493567 \\
\hline & SE & 495570 & 3493546 \\
\hline & SW & 495550 & 3493545 \\
\hline \multirow[t]{4}{*}{37} & $\mathrm{NE}$ & 495623 & 3493721 \\
\hline & NW & 495601 & 3493725 \\
\hline & SE & 495620 & 3493703 \\
\hline & SW & 495600 & 3493706 \\
\hline \multirow[t]{4}{*}{40} & $\mathrm{NE}$ & 495506 & 3494109 \\
\hline & NW & 495486 & 3494115 \\
\hline & SE & 495501 & 3494091 \\
\hline & SW & 495481 & 3494096 \\
\hline \multirow[t]{4}{*}{ AG1 } & $\mathrm{NE}$ & 495450 & 3492673 \\
\hline & NW & 495431 & 3492677 \\
\hline & SE & 495447 & 3492653 \\
\hline & SW & 495427 & 3492657 \\
\hline \multirow[t]{4}{*}{ Bosque1 } & $\mathrm{NE}$ & 495492 & 3492995 \\
\hline & NW & 495474 & 3492996 \\
\hline & SE & 495491 & 3492984 \\
\hline & SW & 495473 & 3492985 \\
\hline \multirow[t]{4}{*}{ Riparian1 } & $\mathrm{NE}$ & 495712 & 3492781 \\
\hline & NW & 495693 & 3492783 \\
\hline & SE & 495705 & 3492761 \\
\hline & SW & 495685 & 3492765 \\
\hline
\end{tabular}


Appendix K. UTM coordinates (NAD 83) for intensive plots for amphibian and reptile surveys, Tumacácori NHP, 2001-2002. Unless otherwise indicated, accuracy is $\pm 1 \mathrm{~m}$.

\begin{tabular}{|c|c|c|c|c|}
\hline Park unit & Plot name & Corner & Easting & Northing \\
\hline \multirow[t]{8}{*}{ Calabazas } & $\mathrm{C} 01^{\mathrm{a}}$ & NW & 503714 & 3479918 \\
\hline & & $\mathrm{NE}$ & 503814 & 3479917 \\
\hline & & SE & 503814 & 3479817 \\
\hline & & SW & 503715 & 3479817 \\
\hline & $\mathrm{CO}^{\mathrm{a}}$ & NW & 503838 & 3479740 \\
\hline & & $\mathrm{NE}$ & 503938 & 3479739 \\
\hline & & SE & 503938 & 3479640 \\
\hline & & SW & 503838 & 3479640 \\
\hline \multirow[t]{4}{*}{ Guevavi } & $\mathrm{G} 01^{\mathrm{a}}$ & NW & 509238 & 3475113 \\
\hline & & $\mathrm{NE}$ & 509338 & 3475113 \\
\hline & & SE & 509338 & 3475013 \\
\hline & & SW & 509238 & 3475013 \\
\hline \multirow[t]{33}{*}{ Tumacácori } & M01 & NW & 495638 & 3493431 \\
\hline & & $\mathrm{NE}$ & 495741 & 3493428 \\
\hline & & SE & 495737 & 3493326 \\
\hline & & SW & 495641 & 3493326 \\
\hline & M02 & SW & 495443 & 3492264 \\
\hline & M03 & SW & 495562 & 3492658 \\
\hline & M04 & SW & 495718 & 3492303 \\
\hline & M05 & SW & 495441 & 3493012 \\
\hline & & SE & 495536 & 3493006 \\
\hline & & $\mathrm{NE}$ & 495543 & 3493107 \\
\hline & & NW & 495433 & 3493112 \\
\hline & M06 & NW & 495663 & 3493080 \\
\hline & & $\mathrm{NE}$ & 495759 & 3493079 \\
\hline & & SE & 495760 & 3492976 \\
\hline & & SW & 495661 & 3492981 \\
\hline & M07 & SW & 495220 & 3492117 \\
\hline & M08 & SE & 495330 & 3492933 \\
\hline & & SW & 495230 & 3492929 \\
\hline & & NW & 495230 & 3493029 \\
\hline & & NE & 495328 & 3493026 \\
\hline & M09 & NW & 495215 & 3493441 \\
\hline & & NE & 495315 & 3493440 \\
\hline & & SE & 495307 & 3493347 \\
\hline & & SW & 495213 & 3493339 \\
\hline & M10 & NW & 495391 & 3492952 \\
\hline & & $\mathrm{NE}$ & 495484 & 3492955 \\
\hline & & SE & 495485 & 3492851 \\
\hline & & SW & 495387 & 3492853 \\
\hline & M11 & SW & 495701 & 3492053 \\
\hline & M12 & NW & 495205 & 3492795 \\
\hline & & NE & 495309 & 3492803 \\
\hline & & SE & 495314 & 3492712 \\
\hline & & SW & 495212 & 3492704 \\
\hline
\end{tabular}

${ }^{a}$ Coordinates are the original used for navigating to the plot when it was established and therefore accuracy is $\pm 30 \mathrm{~m}$. 
Appendix L. UTM coordinates (NAD 83) for bird survey stations and transect sections, Tumacácori NHP, 2001-2003. Accuracy is $\pm 15 \mathrm{~m}$.

\begin{tabular}{|c|c|c|c|c|c|}
\hline Survey type & Unit & Station & Community type ${ }^{a}$ & Easting & Northing \\
\hline \multirow[t]{13}{*}{ VCP } & Calabazas & 1 & SD grassland & 503969 & 3479802 \\
\hline & & 2 & SD grassland & 503775 & 3479906 \\
\hline & & 3 & SD grassland & 503853 & 3479539 \\
\hline & Guevavi & 1 & SD grassland & 509363 & 3474931 \\
\hline & & 2 & SD grassland & 509258 & 3475135 \\
\hline & Tumacácori & 1 & Developed & 495222 & 3492552 \\
\hline & & 2 & Mesquite bosque & 495271 & 3492780 \\
\hline & & 3 & Mesquite bosque & 495540 & 3492734 \\
\hline & & 8 & Mesquite bosque & 495481 & 3492971 \\
\hline & & 6 & Riparian & 495704 & 3492834 \\
\hline & & 4 & Riparian & 495734 & 3492585 \\
\hline & & 5 & Riparian & 495763 & 3492336 \\
\hline & & 7 & Riparian & 495709 & 3493091 \\
\hline \multirow[t]{12}{*}{ Line transect ${ }^{b}$} & Calabazas & $A-B$ & SD grassland & 504033 & 3479757 \\
\hline & & $B-C$ & SD grassland & 503869 & 3479578 \\
\hline & & C-A & SD grassland & 503787 & 3479815 \\
\hline & Guevavi & $A-B$ & SD grassland & 509412 & 3474931 \\
\hline & & $B-A$ & SD grassland & 509232 & 3475107 \\
\hline & Tumacácori & $A-B$ & Developed & 495193 & 3492545 \\
\hline & & $B-C$ & Mesquite bosque & 495228 & 3492790 \\
\hline & & C-D & Mesquite bosque & 495468 & 3492722 \\
\hline & & D-E & Riparian & 495479 & 3492975 \\
\hline & & E-F & Riparian & 495687 & 3492835 \\
\hline & & $F-G$ & Riparian & 495735 & 3492594 \\
\hline & & G-F & Riparian & 495763 & 3492346 \\
\hline \multirow[t]{5}{*}{ Nocturnal breeding season } & Calabazas & 1 & SD grassland & 503817 & 3479774 \\
\hline & Guevavi & 1 & SD grassland & 509363 & 3474931 \\
\hline & Tumacácori & 1 & Developed & 495248 & 3492594 \\
\hline & & 2 & Mesquite bosque & 495520 & 3492715 \\
\hline & & 3 & $\begin{array}{l}\text { Mesquite bosque/ } \\
\text { Riparian }\end{array}$ & 495515 & 3493009 \\
\hline
\end{tabular}

a SD grassland = semi-desert grassland.

${ }^{b}$ Line transect section breaks. 
Appendix M. UTM coordinates (NAD 83) of small mammal trapping plots, Tumacácori NHP, 2000-2001. Accuracy is $\pm 15 \mathrm{~m}$. Park units: "CAL" = Calabazas; "GUV" = Guevavi; "TUM" = Tumacácori.

\begin{tabular}{|c|c|c|c|c|}
\hline$\underline{P a r k}$ unit & Plot name & Corner & Easting & Northing \\
\hline \multirow[t]{36}{*}{ CAL } & \multirow[t]{4}{*}{1} & A1 & 503863 & 3479672 \\
\hline & & A5 & 503896 & 3479674 \\
\hline & & E1 & 503859 & 3479637 \\
\hline & & E5 & 503898 & 3479640 \\
\hline & \multirow[t]{4}{*}{2} & $\mathrm{~A} 1$ & 503948 & 3479656 \\
\hline & & A5 & 503930 & 3479685 \\
\hline & & E1 & 503968 & 3479679 \\
\hline & & E5 & 503959 & 3479699 \\
\hline & \multirow[t]{4}{*}{3} & $\mathrm{~A} 1$ & 503846 & 3479547 \\
\hline & & A5 & 503821 & 3479561 \\
\hline & & E1 & 503864 & 3479565 \\
\hline & & E5 & 503845 & 3479580 \\
\hline & \multirow[t]{4}{*}{4} & $\mathrm{~A} 1$ & 503916 & 3479830 \\
\hline & & A5 & 503911 & 3479791 \\
\hline & & E1 & 503948 & 3479824 \\
\hline & & E5 & 503948 & 3479791 \\
\hline & \multirow[t]{4}{*}{5} & $\mathrm{~A} 1$ & 503783 & 3479870 \\
\hline & & A5 & 503779 & 3479905 \\
\hline & & E1 & 503754 & 3479883 \\
\hline & & E5 & 503757 & 3479917 \\
\hline & \multirow[t]{4}{*}{6} & $\mathrm{~A} 1$ & 503853 & 3479905 \\
\hline & & A5 & 503852 & 3479939 \\
\hline & & E1 & 503824 & 3479908 \\
\hline & & E5 & 503816 & 3479940 \\
\hline & \multirow[t]{4}{*}{ C1 } & $\mathrm{NE}$ & 503870 & 3479868 \\
\hline & & NW & 503830 & 3479868 \\
\hline & & SE & 503870 & 3479828 \\
\hline & & SW & 503830 & 3479828 \\
\hline & \multirow[t]{4}{*}{ C2 } & $\mathrm{NE}$ & 503798 & 3479827 \\
\hline & & NW & 503758 & 3479827 \\
\hline & & SE & 503798 & 3479787 \\
\hline & & SW & 503758 & 3479787 \\
\hline & \multirow[t]{4}{*}{ C3 } & $\mathrm{NE}$ & 503834 & 3479696 \\
\hline & & NW & 503794 & 3479696 \\
\hline & & SE & 503834 & 3479656 \\
\hline & & SW & 503794 & 3479656 \\
\hline \multirow[t]{17}{*}{ GUV } & \multirow[t]{4}{*}{1} & $\mathrm{~A} 1$ & 509397 & 3474969 \\
\hline & & A5 & 509414 & 3474933 \\
\hline & & E1 & 509364 & 3474950 \\
\hline & & E5 & 509379 & 3474921 \\
\hline & \multirow[t]{4}{*}{2} & $\mathrm{~A} 1$ & 509228 & 3475102 \\
\hline & & A5 & 509226 & 3475072 \\
\hline & & E1 & 509256 & 3475096 \\
\hline & & E5 & 509255 & 3475068 \\
\hline & \multirow[t]{4}{*}{ G1 } & $\mathrm{NE}$ & 509305 & 3475108 \\
\hline & & NW & 509265 & 3475108 \\
\hline & & SE & 509305 & 3475068 \\
\hline & & SW & 509265 & 3475068 \\
\hline & \multirow[t]{4}{*}{ G2 } & $\mathrm{NE}$ & 509329 & 3475034 \\
\hline & & NW & 509289 & 3475034 \\
\hline & & SE & 509329 & 3474994 \\
\hline & & SW & 509289 & 3474994 \\
\hline & G3 & NE & 509400 & 3475023 \\
\hline
\end{tabular}

\begin{tabular}{|c|c|c|c|c|}
\hline Park unit & Plot name & Corner & Easting & Northing \\
\hline & & NW & 509360 & 3475023 \\
\hline \multirow[t]{2}{*}{ GUV } & G3 & SE & 509400 & 3474983 \\
\hline & & SW & 509360 & 3474983 \\
\hline \multirow[t]{44}{*}{ TUM } & M12 & $\mathrm{NE}$ & 495666 & 3493383 \\
\hline & & NW & 495576 & 3493383 \\
\hline & & SE & 495666 & 3493343 \\
\hline & & SW & 495576 & 3493343 \\
\hline & M16 & $\mathrm{NE}$ & 495244 & 3492921 \\
\hline & & NW & 495154 & 3492921 \\
\hline & & SE & 495244 & 3492881 \\
\hline & & SW & 495154 & 3492881 \\
\hline & M17 & $\mathrm{NE}$ & 495346 & 3492782 \\
\hline & & NW & 495256 & 3492782 \\
\hline & & SE & 495346 & 3492742 \\
\hline & & SW & 495256 & 3492742 \\
\hline & M03 & $\mathrm{NE}$ & 495350 & 3493401 \\
\hline & & NW & 495260 & 3493401 \\
\hline & & SE & 495350 & 3493361 \\
\hline & & SW & 495260 & 3493361 \\
\hline & M04 & $\mathrm{NE}$ & 495677 & 3491978 \\
\hline & & NW & 495587 & 3491978 \\
\hline & & SE & 495677 & 3491938 \\
\hline & & SW & 495587 & 3491938 \\
\hline & M06 & $\mathrm{NE}$ & 495551 & 3493272 \\
\hline & & NW & 495461 & 3493272 \\
\hline & & SE & 495551 & 3493232 \\
\hline & & SW & 495461 & 3493232 \\
\hline & M07 & $\mathrm{NE}$ & 495466 & 3493077 \\
\hline & & NW & 495376 & 3493077 \\
\hline & & SE & 495466 & 3493037 \\
\hline & & SW & 495376 & 3493037 \\
\hline & M09 & $\mathrm{NE}$ & 495281 & 3493095 \\
\hline & & NW & 495191 & 3493095 \\
\hline & & SE & 495281 & 3493055 \\
\hline & & SW & 495191 & 3493055 \\
\hline & M02 & $\mathrm{NE}$ & 495570 & 3492805 \\
\hline & & NW & 495480 & 3492805 \\
\hline & & SE & 495570 & 3492765 \\
\hline & & SW & 495480 & 3492765 \\
\hline & M11 & $\mathrm{NE}$ & 495433 & 3492600 \\
\hline & & NW & 495343 & 3492600 \\
\hline & & SE & 495433 & 3492560 \\
\hline & & SW & 495343 & 3492560 \\
\hline & M14 & $\mathrm{NE}$ & 495619 & 3492611 \\
\hline & & NW & 495529 & 3492611 \\
\hline & & SE & 495619 & 3492571 \\
\hline & & SW & 495529 & 3492571 \\
\hline
\end{tabular}


Appendix N. Museums that were queried in 1998 for vertebrate voucher specimens with "Arizona" and "Tumacácori National Historical Park" in the collection location. Collections in bold had specimens from Tumacácori NHP.

\begin{tabular}{|c|c|}
\hline Collection & Vertebrate group(s) \\
\hline Auburn University & Reptiles and amphibians \\
\hline Chicago Academy of Sciences & All \\
\hline Cincinnati Museum of Natural History \& Science & All \\
\hline Cornell Vertebrate Collections, Cornell University & Birds and mammals \\
\hline Field Museum of Natural History, Chicago & Mammals \\
\hline George Mason University (Fairfax, VA) & All \\
\hline James Ford Bell Museum of Natural History, University of Minnesota & Mammals \\
\hline $\begin{array}{l}\text { Laboratory for Environmental Biology, Centennial Museum, University of Texas at El } \\
\text { Paso }\end{array}$ & Unknown \\
\hline Marjorie Barrick Museum, University of Nevada-Las Vegas & Reptiles, amphibians, and birds \\
\hline Michigan State University Museum (East Lansing) & All \\
\hline Milwaukee Public Museum & All \\
\hline Monte Bean Life Science Museum, Brigham Young University & Unknown \\
\hline Museum of Comparative Zoology, Harvard University & Reptiles and amphibians \\
\hline Museum of Texas Tech University & All \\
\hline Museum of Natural History, University of Kansas & Reptiles, amphibians, and mammals \\
\hline Museum of Vertebrate Zoology, University of California, Berkeley & All \\
\hline Museum of Life Sciences, Louisiana State University, Shreveport & All \\
\hline Natural History Museum of Los Angeles County & Reptiles and amphibians \\
\hline New Mexico Museum of Natural History (Albuquerque) & Unknown \\
\hline North Carolina State Museum of Natural Sciences & Birds and mammals \\
\hline Oklahoma Museum of Natural History, Norman & All \\
\hline Peabody Museum, Yale University & All \\
\hline Pipe Spring National Memorial, Arizona & Mammals \\
\hline Saguaro National Park & All \\
\hline Sharlot Hall Museum, Prescott, Arizona & Unknown \\
\hline Strecker Museum, Baylor University, Waco & All \\
\hline Texas Cooperative Wildlife Collection & All but fish \\
\hline Tulane University Museum of Natural History & Reptiles and amphibians \\
\hline University of Arizona & All \\
\hline University of Texas, Arlington & All \\
\hline University of Illinois, Champaign-Urbana & All \\
\hline University of Michigan & Reptiles and amphibians \\
\hline University of Colorado Museum & All \\
\hline Walnut Canyon National Monument, Arizona & All \\
\hline Western Archeological and Conservation Center, Tucson & All \\
\hline Wupatki National Memorial, Flagstaff & All \\
\hline
\end{tabular}


Appendix 0. Voucher specimens from Tumacácori NHP that were not collected by University of Arizona Inventory personnel. See appendix $\mathrm{N}$ for list of collections that were queried for specimens from "Tumacácori National Historical Park".

\begin{tabular}{|c|c|c|c|c|c|c|}
\hline $\begin{array}{l}\text { Taxon } \\
\text { group }\end{array}$ & Scientific name & Common name & Collection & Date & Collector & $\begin{array}{l}\text { Number of } \\
\text { specimens } \\
\text { (if known) }\end{array}$ \\
\hline \multirow[t]{2}{*}{ Reptiles } & Sceloporus clarkii & Clark's spiny lizard & Chicago Academy of Science & $01 / 01 / 1940$ & J. Y. Beaty & 1 \\
\hline & Pituophis catenifer & gopher snake & University of Arizona & $06 / 28 / 1962$ & R.L. Bezy & 1 \\
\hline \multirow[t]{30}{*}{ Birds } & Callipepla gambelii & Gambel's quail & University of Arizona & NA & NA & 2 \\
\hline & Accipiter cooperii & Cooper's hawk & University of Arizona & $\mathrm{NA}$ & $\mathrm{NA}$ & \\
\hline & Buteo swainsoni & Swainson's hawk & University of Arizona & NA & NA & \\
\hline & Buteo albonotatus & zone-tailed hawk & University of Arizona & NA & NA & \\
\hline & Falco sparverius & American kestrel & University of Arizona & NA & NA & \\
\hline & Patagioenas fasciata & band-tailed pigeon & University of Arizona & NA & NA & \\
\hline & Cynanthus latirostris & broad-billed hummingbird & University of Arizona & NA & NA & \\
\hline & Camptostoma imberbe & $\begin{array}{l}\text { northern beardless- } \\
\text { tyrannulet }\end{array}$ & University of Arizona & NA & NA & \\
\hline & Contopus sordidulus & western wood-pewee & University of Arizona & $\mathrm{NA}$ & NA & \\
\hline & Pyrocephalus rubinus & vermilion flycatcher & University of Arizona & NA & NA & \\
\hline & Myiarchus tuberculifer & dusky-capped flycatcher & University of Arizona & $\mathrm{NA}$ & NA & \\
\hline & Myiarchus cinerascens & ash-throated flycatcher & University of Arizona & NA & NA & 2 \\
\hline & Myiarchus tyrannulus & brown-crested flycatcher & University of Arizona & NA & NA & \\
\hline & Tyrannus vociferans & Cassin's kingbird & University of Arizona & $\mathrm{NA}$ & NA & 2 \\
\hline & Lanius ludovicianus & loggerhead shrike & University of Arizona & $\mathrm{NA}$ & $\mathrm{NA}$ & \\
\hline & Vireo gilvus & warbling vireo & University of Arizona & NA & NA & \\
\hline & Auriparus flaviceps & verdin & University of Arizona & NA & $\mathrm{NA}$ & \\
\hline & Thryomanes bewickii & Bewick's wren & University of Arizona & $\mathrm{NA}$ & NA & \\
\hline & Mimus polyglottos & northern mockingbird & University of Arizona & $\mathrm{NA}$ & NA & \\
\hline & Toxostoma curvirostre & curve-billed thrasher & University of Arizona & NA & NA & 2 \\
\hline & Phainopepla nitens & phainopepla & University of Arizona & $\mathrm{NA}$ & NA & 2 \\
\hline & Vermivora luciae & Lucy's warbler & University of Arizona & $\mathrm{NA}$ & NA & \\
\hline & Icteria virens & yellow-breasted chat & University of Arizona & NA & NA & \\
\hline & Piranga flava & hepatic tanager & University of Arizona & $\mathrm{NA}$ & NA & \\
\hline & Pipilo fuscus & canyon towhee & University of Arizona & NA & NA & \\
\hline & Cardinalis cardinalis & northern cardinal & University of Arizona & $\mathrm{NA}$ & NA & \\
\hline & Passerina caerulea & blue grosbeak & University of Arizona & $\mathrm{NA}$ & NA & \\
\hline & Passerina versicolor & varied bunting & University of Arizona & NA & NA & \\
\hline & Molothrus ater & brown-headed cowbird & University of Arizona & NA & NA & 3 \\
\hline & Carpodacus mexicanus & house finch & University of Arizona & NA & NA & \\
\hline \multirow[t]{9}{*}{ Mammals } & Antrozous pallidus ${ }^{a}$ & pallid bat & Saguaro National Park & 1938,1950 & $\begin{array}{c}\text { A. G. } \\
\text { Henson }\end{array}$ & 4 \\
\hline & Macrotus californicus ${ }^{a}$ & Calfornia leaf-nosed bat & Saguaro National Park & 1950 & $\begin{array}{c}\text { A. G. } \\
\text { Henson }\end{array}$ & 1 \\
\hline & Myotis californicus ${ }^{a}$ & California myotis & Saguaro National Park & & $\begin{array}{l}\text { A. G. } \\
\text { Henson }\end{array}$ & 2 \\
\hline & Myotis velifer & cave myotis & University of California, Berkele & 1937 & $\begin{array}{c}\text { W. B. } \\
\text { Richardson }\end{array}$ & 71 \\
\hline & Myotis velifera & cave myotis & Saguaro National Park & $\overline{1950,1951}$ & $\begin{array}{c}\text { A. G. } \\
\text { Henson }\end{array}$ & 7 \\
\hline & Myotis velifera & cave myotis & Saguaro National Park & 1937 & S. Benson & 2 \\
\hline & Tadarida brasiliensis ${ }^{a}$ & Brazilian free-tailed bat & Saguaro National Park & 1950 & $\begin{array}{c}\text { A. G. } \\
\text { Henson }\end{array}$ & 3 \\
\hline & Odocoileus virginianus & white-tailed deer & University of Arizona & $11 / 07 / 1966$ & Don Mott & \\
\hline & Odocoileus virginianus & white-tailed deer & University of Arizona & $10 / 30 / 1964$ & A. Peyron & \\
\hline
\end{tabular}

a Specimen identification not verified. 
Appendix P. Vertebrate voucher specimens collected at Tumacácori NHP by University of Arizona Inventory personnel, 2000-2002. All specimens are located in University of Arizona collections. Park units: "CAL" = Calabazas; "GUV" = Guevavi; "TUM" = Tumacácori.

\begin{tabular}{|c|c|c|c|c|c|c|}
\hline $\begin{array}{l}\text { Taxon } \\
\text { group }\end{array}$ & Park unit & Common name & Date & Collector & $\begin{array}{c}\text { Accession } \\
\text { number }\end{array}$ & Specimen type \\
\hline \multicolumn{7}{|c|}{ Amphibians and Reptiles } \\
\hline & \multirow[t]{2}{*}{ GUV } & Mexican spadefoot & 07/12/01 & James Borgmeyer & 53512 & full \\
\hline & & western patch-nosed Snake & $07 / 02 / 01$ & Dan Bell & 53816 & full \\
\hline & \multirow[t]{8}{*}{ TUM } & Couch's spadefoot & $07 / 11 / 01$ & James Borgmeyer & 53513 & full \\
\hline & & Woodhouse's toad & $07 / 10 / 02$ & Kevin Bonine & & full \\
\hline & & Clark's spiny lizard & $07 / 11 / 02$ & Dan Bell & & full \\
\hline & & desert grassland whiptail & $07 / 11 / 02$ & Kevin Bonine & 53989 & full \\
\hline & & Sonoran spotted whiptail & $04 / 25 / 01$ & Mike Wall & 53648 & full \\
\hline & & Sonoran spotted whiptail & $07 / 11 / 01$ & James Borgmeyer & 53511 & full \\
\hline & & Sonoran spotted whiptail & $07 / 10 / 02$ & Kevin Bonine & 53988 & full \\
\hline & & long-nosed snake & $04 / 11 / 01$ & Dave Prival & 53514 & full \\
\hline \multirow[t]{7}{*}{ Fish } & \multirow[t]{7}{*}{ TUM } & desert sucker & $05 / 15 / 02$ & Eric Albrecht & & full \\
\hline & & Sonora sucker & $05 / 15 / 02$ & Eric Albrecht & 346 & full \\
\hline & & longfin dace & $05 / 15 / 02$ & Eric Albrecht & 345 & full \\
\hline & & western mosquitofish & $05 / 15 / 02$ & Eric Albrecht & 344 & full \\
\hline & & green sunfish & $05 / 15 / 02$ & Eric Albrecht & 343 & full \\
\hline & & largemouth bass & $05 / 15 / 02$ & Eric Albrecht & 341 & full \\
\hline & & bluegill sunfish & $05 / 15 / 02$ & Eric Albrecht & 342 & full \\
\hline \multirow[t]{30}{*}{ Mammals } & \multirow[t]{12}{*}{ CAL } & unknown desert shrew & $09 / 24 / 00$ & Jason Schmidt & 26900 & $\begin{array}{l}\text { skull and } \\
\text { skeleton }\end{array}$ \\
\hline & & Sonoran desert pocket mouse & $09 / 23 / 00$ & Jason Schmidt & 26862 & skull \\
\hline & & Bailey's pocket mouse & $09 / 23 / 00$ & Jason Schmidt & 26904 & skull \\
\hline & & fulvous harvest mouse & $09 / 23 / 00$ & Neil Perry & 26863 & skull \\
\hline & & cactus mouse & $09 / 23 / 00$ & Jason Schmidt & 26838 & skin and skull \\
\hline & & cactus mouse & 06/13/01 & Ryan Gann & 26832 & skin and skull \\
\hline & & house mouse & $06 / 12 / 01$ & Neil Perry & 26858 & skin and skull \\
\hline & & deer mouse & $09 / 25 / 00$ & Ryan Gann & 26907 & skull \\
\hline & & white-footed mouse & $09 / 25 / 00$ & Neil Perry & submitteda $^{a}$ & skull \\
\hline & & southern grasshopper mouse & $09 / 23 / 00$ & Neil Perry & 26861 & skull \\
\hline & & western white-throated woodrat & $09 / 24 / 00$ & Jason Schmidt & 26899 & skull \\
\hline & & tawny-belled cotton rat & $09 / 23 / 00$ & Jason Schmidt & 26929 & skull \\
\hline & \multirow[t]{8}{*}{ GUV } & Sonoran desert pocket mouse & $09 / 30 / 00$ & Neil Perry & 26934 & skull \\
\hline & & Sonoran desert pocket mouse & $10 / 02 / 00$ & Jason Schmidt & 26933 & skull \\
\hline & & Bailey's pocket mouse & $09 / 30 / 00$ & Neil Perry & 26908 & skull \\
\hline & & fulvous harvest mouse & $10 / 02 / 00$ & Jason Schmidt & 26864 & skull \\
\hline & & cactus mouse & $09 / 30 / 00$ & Jason Schmidt & 26860 & skull \\
\hline & & northern pygmy mouse & $06 / 13 / 01$ & Neil Perry & 26891 & skin and skull \\
\hline & & southern grasshopper mouse & $10 / 02 / 00$ & Jason Schmidt & 26931 & skull \\
\hline & & western white-throated woodrat & $09 / 30 / 00$ & Neil Perry & submitteda & skull \\
\hline & \multirow[t]{10}{*}{ TUM } & desert shrew & $10 / 29 / 00$ & Neil Perry & 26902 & skull \\
\hline & & feral cat & $10 / 18 / 02$ & Neil Perry & 26766 & skull \\
\hline & & bobcat & $02 / 27 / 03$ & Neil Perry & submitteda $^{a}$ & skull \\
\hline & & Botta's pocket gopher & $11 / 03 / 00$ & Jason Schmidt & 27049 & skull \\
\hline & & Sonoran desert pocket mouse & $10 / 29 / 00$ & Jason Schmidt & 26865 & skull \\
\hline & & Sonoran desert pocket mouse & $11 / 03 / 00$ & Jason Schmidt & 26923 & skull \\
\hline & & Sonoran desert pocket mouse & $11 / 05 / 00$ & Jason Schmidt & 26912 & skull \\
\hline & & western harvest mouse & $06 / 05 / 01$ & Neil Perry & 26859 & skin and skull \\
\hline & & cactus mouse & $10 / 29 / 00$ & Jason Schmidt & 26909 & skull \\
\hline & & cactus mouse & $10 / 29 / 00$ & Jason Schmidt & 26905 & skull \\
\hline
\end{tabular}




\begin{tabular}{lllllll}
\hline $\begin{array}{l}\text { Taxon } \\
\text { group }\end{array}$ & Park unit & Common name & Date & Collector & $\begin{array}{c}\text { Accession } \\
\text { number }\end{array}$ & Specimen type \\
\hline Mammals & TUM & cactus mouse & $10 / 31 / 00$ & Jason Schmidt & 26924 & skull \\
\hline & & cactus mouse & $11 / 04 / 00$ & Jason Schmidt & 26914 & skull \\
\hline & & deer mouse & $10 / 31 / 00$ & Ryan Gann & 26906 & skull \\
\hline & Arizona cotton rat & $10 / 29 / 00$ & Neil Perry & submitted $^{a}$ & \\
\hline
\end{tabular}

a Voucher specimen submitted but has not been accessioned. 
Appendix Q. Summary of plant data from modular plots, Tumacácori NHP, 2002. All plots had four modules except "Bosque 1", which had two modules. See Appendix A for scientific names.

\begin{tabular}{|c|c|c|c|c|c|c|c|c|}
\hline \multirow[b]{2}{*}{ Plot name } & \multirow[b]{2}{*}{ Common name } & \multicolumn{5}{|c|}{ Frequency of occurrence in modular quadrata } & \multicolumn{2}{|c|}{$\begin{array}{c}\text { Total number of point intercepts } \\
\text { along transects }\end{array}$} \\
\hline & & $10 \times 10$ & NE & NW & SE & SW & $\begin{array}{l}\text { Number of } \\
\text { modules and } \\
\text { plots }^{c}\end{array}$ & Intercept sumb \\
\hline \multirow[t]{8}{*}{1} & carelessweed & 4 & & 2 & 2 & & & \\
\hline & desert broom & 3 & & & & & & \\
\hline & feather fingergrass & 1 & & & & & & \\
\hline & few-flower beggarticks & 1 & & & 1 & & & \\
\hline & needle grama & 3 & & 2 & & & 1 & 1 \\
\hline & prickly Russian thistle & 3 & & & 1 & & & \\
\hline & stinkgrass & 1 & & & & & & \\
\hline & velvet mesquite & 4 & & 1 & & & 5 & 202 \\
\hline \multirow[t]{10}{*}{4} & bloodberry rougeplant & 2 & & & & & 2 & 13 \\
\hline & carelessweed & 4 & & 4 & 3 & & 6 & 80 \\
\hline & catclaw & 6 & & & & & 6 & 188 \\
\hline & climbing spiderling & 2 & & & & & & \\
\hline & graythorn & 5 & & & & & 3 & 28 \\
\hline & needle grama & 2 & & & 1 & & & \\
\hline & netleaf hackberry & 2 & & & & & & \\
\hline & ragweed & 1 & & & 1 & & & \\
\hline & snailseed & 6 & & & & & 3 & 36 \\
\hline & velvet mesquite & 2 & & & & & 2 & 23 \\
\hline \multirow[t]{19}{*}{6} & Bermudagrass & 2 & & 1 & & & & \\
\hline & cane cholla & 2 & & & & & & \\
\hline & carelessweed & 8 & & 5 & 6 & & 5 & 39 \\
\hline & cheeseweed burrobrush & 9 & & 2 & 4 & & 8 & 37 \\
\hline & doubleclaw & 1 & & & & & & \\
\hline & entireleaf morningglory & 5 & & 1 & 4 & & & \\
\hline & feather fingergrass & 4 & & & & & 2 & 6 \\
\hline & few-flower beggarticks & 1 & & 1 & & & & \\
\hline & flatcrown buckwheat & 2 & & & & & & \\
\hline & gooding willow & 2 & & 2 & & & & \\
\hline & miniature woollystar & 1 & & & & & & \\
\hline & mule's fat & 3 & & 1 & 2 & & & \\
\hline & needle grama & 3 & & 1 & & & 2 & 30 \\
\hline & prickly Russian thistle & 5 & & & 2 & & 4 & 7 \\
\hline & sand dropseed & 1 & & & & & & \\
\hline & sixweeks threeawn & 2 & & & & & & \\
\hline & tapertip cupgrass & 1 & & & & & & \\
\hline & tropical blazingstar & 1 & & 1 & & & 1 & 1 \\
\hline & white blazingstar & 2 & & & & & & \\
\hline \multirow[t]{15}{*}{$8 \mathrm{~A}$} & Arizona black walnut & 3 & & & & & 1 & 2 \\
\hline & Bermudagrass & 5 & 2 & 2 & & 1 & 1 & 6 \\
\hline & Fremont cottonwood & 12 & 3 & 4 & 3 & 2 & 5 & 126 \\
\hline & Johnsongrass & 3 & & & & & & \\
\hline & Jungle ricegrass & 2 & & & & & & \\
\hline & New Mexico copperleaf & 2 & & & & & 1 & 9 \\
\hline & carelessweed & 3 & & & & 2 & & \\
\hline & desert broom & 3 & & & & & & \\
\hline & entireleaf morningglory & 5 & & 2 & & & & \\
\hline & few-flower beggarticks & 4 & 1 & 2 & 1 & & 2 & 14 \\
\hline & fringed twinevine & 3 & & & & & 1 & 1 \\
\hline & gooding willow & 12 & 2 & 2 & 3 & 3 & 11 & 302 \\
\hline & hairy crabgrass & 1 & & & & & & \\
\hline & mule's fat & 4 & & & & & 4 & 20 \\
\hline & netleaf hackberry & 1 & & & & & & \\
\hline
\end{tabular}




\begin{tabular}{|c|c|c|c|c|c|c|c|c|}
\hline \multirow[b]{2}{*}{ Plot name } & \multirow[b]{2}{*}{ Common name } & \multicolumn{5}{|c|}{ Frequency of occurrence in modular quadrata } & \multicolumn{2}{|c|}{$\begin{array}{c}\text { Total number of point intercepts } \\
\text { along transects }\end{array}$} \\
\hline & & $10 \times 10$ & NE & NW & SE & SW & plots $^{\mathrm{c}}$ & Intercept sumb \\
\hline \multirow[t]{5}{*}{$8 \mathrm{~A}$} & prickly Russian thistle & 2 & & & & & & \\
\hline & ragweed & 1 & & & & & & \\
\hline & sacred thorn-apple & 1 & & & & & & \\
\hline & tapertip cupgrass & 1 & & & & & & \\
\hline & velvet ash & 3 & & & & & & \\
\hline \multirow[t]{30}{*}{9} & Bermudagrass & 5 & 1 & 1 & 1 & & 3 & 18 \\
\hline & Fremont cottonwood & 12 & & & & & 2 & 55 \\
\hline & Johnsongrass & 4 & 2 & & & & & \\
\hline & Lehmann's lovegrass & 1 & & & 1 & & 1 & 8 \\
\hline & Mexican fireplant & 2 & & & & & 1 & 2 \\
\hline & New Mexico copperleaf & 3 & 1 & 1 & & & & \\
\hline & annual goldeneye & 2 & & & & & & \\
\hline & blood ragweed & 3 & 1 & 1 & & & & \\
\hline & canyon morning-glory & 1 & & 1 & & & & \\
\hline & carelessweed & 8 & 1 & 5 & 6 & 2 & 6 & 64 \\
\hline & cocklebur & 4 & & 1 & & & & \\
\hline & common sunflower & 4 & & & & & & \\
\hline & cutleaf goldenweed & 3 & & 1 & & & & \\
\hline & desert broom & 3 & & & & & & \\
\hline & entireleaf morningglory & 5 & & & & & & \\
\hline & feather fingergrass & 8 & 1 & 1 & 3 & 2 & 1 & 3 \\
\hline & few-flower beggarticks & 6 & 1 & 2 & 2 & 1 & 3 & 6 \\
\hline & gooding willow & 6 & 1 & & & & 2 & 77 \\
\hline & hairy crabgrass & 4 & 1 & 2 & & & & \\
\hline & hyssop spurge & 2 & & 1 & & & & \\
\hline & low rattlebox & 2 & & & & & & \\
\hline & needle grama & 5 & 1 & 1 & & 2 & 2 & 15 \\
\hline & plains lovegrass & 3 & & 2 & & & 1 & 1 \\
\hline & prickly Russian thistle & 1 & & & & & & \\
\hline & ragweed & 7 & & & & & & \\
\hline & sand dropseed & 2 & 1 & & & & 1 & 1 \\
\hline & stinkgrass & 1 & & & & & & \\
\hline & tapertip cupgrass & 6 & 1 & 3 & 2 & 2 & 4 & 11 \\
\hline & yellow sweet-clover & 3 & & & & & & \\
\hline & yewleaf willow & 3 & & & & & 2 & 28 \\
\hline \multirow[t]{19}{*}{13} & Arizona signalgrass & 2 & & & & & & \\
\hline & Bermudagrass & 1 & & & & & & \\
\hline & Mexican morningglory & & & & & & 1 & 2 \\
\hline & Rothrock's grama & 4 & & & & & & \\
\hline & buff petal & 2 & & & & 1 & 1 & 1 \\
\hline & burrow goldenweed & 2 & & & & & & \\
\hline & carelessweed & 5 & & 1 & & & & \\
\hline & climbing spiderling & 2 & & & & & & \\
\hline & crestrib morning-glory & 2 & 1 & & & & & \\
\hline & cutleaf goldenweed & 3 & & & & & & \\
\hline & desert broom & 8 & & & & & 3 & 6 \\
\hline & desert ceanothus & 2 & & & & & 2 & 7 \\
\hline & feather fingergrass & 1 & & & & & & \\
\hline & fringed twinevine & 1 & & & & & 1 & 3 \\
\hline & needle grama & 4 & & 2 & 1 & & 1 & 4 \\
\hline & prickly Russian thistle & 4 & 1 & 1 & 2 & 1 & & \\
\hline & procumbent sida & 4 & & 2 & 2 & & 2 & 2 \\
\hline & ragweed & 4 & & 1 & & & 1 & 1 \\
\hline & sand dropseed & 4 & & & & & & \\
\hline
\end{tabular}




\begin{tabular}{|c|c|c|c|c|c|c|c|c|}
\hline \multirow[b]{2}{*}{ Plot name } & \multirow[b]{2}{*}{ Common name } & \multicolumn{5}{|c|}{ Frequency of occurrence in modular quadrata } & \multicolumn{2}{|c|}{$\begin{array}{c}\text { Total number of point intercepts } \\
\text { along transects }\end{array}$} \\
\hline & & $10 \times 10$ & NE & NW & SE & SW & plots $^{c}$ & Intercept sumb \\
\hline \multirow[t]{7}{*}{13} & sixweeks grama & 3 & & & & & & \\
\hline & slender grama & 1 & & 1 & & & & \\
\hline & southwestern prickly poppy & 1 & & & & & & \\
\hline & spidergrass & 11 & & & & & 3 & 17 \\
\hline & stinkgrass & 3 & & & 1 & & & \\
\hline & threadleaf snakeweed & 2 & & & & & & \\
\hline & velvet mesquite & 11 & 4 & & 2 & 3 & 12 & 416 \\
\hline \multirow[t]{21}{*}{16} & Bermudagrass & 2 & & & & & & \\
\hline & Fremont cottonwood & 4 & & & 1 & & 2 & 164 \\
\hline & Mexican fireplant & 3 & & & 1 & & & \\
\hline & Mexican yellowshow & 1 & & & & & & \\
\hline & New Mexico copperleaf & 4 & & & & & & \\
\hline & bloodberry rougeplant & 2 & & 1 & & & & \\
\hline & blue elderberry & 3 & & & & & & \\
\hline & buff petal & 1 & & & & & & \\
\hline & catclaw & 1 & & & & & 3 & 14 \\
\hline & climbing spiderling & & & & & & 2 & 3 \\
\hline & desert broom & 4 & & 1 & & & 2 & 17 \\
\hline & entireleaf morningglory & 3 & & 1 & & & & \\
\hline & few-flower beggarticks & 4 & & 2 & 2 & & 2 & 5 \\
\hline & graythorn & 7 & & & & & & \\
\hline & netleaf hackberry & 4 & & & & & 1 & 1 \\
\hline & ragweed & 1 & & & 1 & & & \\
\hline & snailseed & 6 & & 1 & 1 & & 1 & 3 \\
\hline & tapertip cupgrass & 1 & & & & & & \\
\hline & threadleaf groundsel & 1 & & & & & & \\
\hline & tropical blazingstar & 4 & & 2 & 2 & & & \\
\hline & velvet mesquite & 11 & & 3 & 5 & & 7 & 283 \\
\hline \multirow[t]{11}{*}{18} & Bermudagrass & 1 & & & & & & \\
\hline & Lehmann's lovegrass & 6 & & & & & & \\
\hline & carelessweed & 8 & 4 & 3 & 2 & 4 & 3 & 13 \\
\hline & cheeseweed burrobrush & 5 & & & & & 1 & 7 \\
\hline & desert broom & 2 & & & & 2 & & \\
\hline & feather fingergrass & 8 & & 2 & & & 1 & 11 \\
\hline & few-flower beggarticks & 2 & 2 & & & & & \\
\hline & needle grama & 4 & 1 & 1 & 1 & 1 & 3 & 43 \\
\hline & prickly Russian thistle & 8 & 2 & 2 & & & & \\
\hline & sorrel buckwheat & 8 & 2 & & 2 & & 1 & 1 \\
\hline & tapertip cupgrass & 3 & & & & & & \\
\hline \multirow[t]{15}{*}{$21 \mathrm{~A}$} & Bermudagrass & 5 & & & 1 & & 1 & 3 \\
\hline & Lehmann's lovegrass & 1 & & & & & & \\
\hline & annual pricklepoppy & 2 & & & & & & \\
\hline & blue grama & 1 & & & & & & \\
\hline & carelessweed & 8 & 4 & 4 & 4 & 4 & 4 & 19 \\
\hline & common sunflower & 2 & & & & & & \\
\hline & feather fingergrass & 8 & 2 & 3 & 2 & 2 & 4 & 18 \\
\hline & few-flower beggarticks & 1 & & & & 1 & & \\
\hline & field sandbur & 8 & & & & & & \\
\hline & needle grama & 4 & 1 & 2 & 2 & 1 & 4 & 81 \\
\hline & ragweed & 2 & 1 & & & & & \\
\hline & sand dropseed & & & & & & 1 & 2 \\
\hline & spidergrass & 2 & & & & & & \\
\hline & stinkgrass & 2 & & & & & & \\
\hline & tapertip cupgrass & 4 & 1 & 1 & 1 & 2 & 4 & 20 \\
\hline
\end{tabular}




\begin{tabular}{|c|c|c|c|c|c|c|c|c|}
\hline \multirow[b]{2}{*}{ Plot name } & \multirow[b]{2}{*}{ Common name } & \multicolumn{5}{|c|}{ Frequency of occurrence in modular quadrata } & \multicolumn{2}{|c|}{$\begin{array}{c}\text { Total number of point intercepts } \\
\text { along transects }\end{array}$} \\
\hline & & $10 \times 10$ & NE & NW & SE & SW & plots $^{\mathrm{c}}$ & Intercept sumb \\
\hline \multirow[t]{3}{*}{$21 \mathrm{~A}$} & threadleaf groundsel & & & & & & 5 & 28 \\
\hline & tropical blazingstar & 2 & & & & 2 & & \\
\hline & white blazingstar & 1 & & & & & 1 & 2 \\
\hline \multirow[t]{23}{*}{$24 \mathrm{~A}$} & Bermudagrass & 5 & 2 & 1 & 1 & & 4 & 11 \\
\hline & Fremont cottonwood & 4 & & & 1 & & 3 & 190 \\
\hline & Grisebach's bristlegrass & 2 & 1 & & & & & \\
\hline & Mexican fireplant & 4 & & 2 & & 1 & 2 & 3 \\
\hline & New Mexico copperleaf & 2 & & & 1 & & 1 & 2 \\
\hline & blue elderberry & 12 & 1 & 4 & & 2 & 1 & 9 \\
\hline & carelessweed & 7 & 2 & & & & 3 & 3 \\
\hline & coastal sandbur & 3 & & & 1 & & 1 & 3 \\
\hline & crested anoda & 1 & & & & & & \\
\hline & feather fingergrass & 2 & & & 1 & & 1 & 1 \\
\hline & few-flower beggarticks & 5 & 1 & 3 & 2 & 1 & 4 & 11 \\
\hline & fringed twinevine & 9 & & 2 & 2 & & 2 & 6 \\
\hline & graythorn & 5 & & & & & 2 & 12 \\
\hline & needle grama & 2 & & 1 & 1 & & & \\
\hline & netleaf hackberry & 7 & & & 1 & & 3 & 40 \\
\hline & prairie sunflower & 3 & & & & & & \\
\hline & prickly Russian thistle & 3 & & & 1 & & & \\
\hline & ragweed & 5 & 1 & & 2 & & 2 & 3 \\
\hline & sand dropseed & 6 & & & 1 & & & \\
\hline & snailseed & 12 & & 5 & 3 & 3 & & \\
\hline & stinkgrass & & & & & & 1 & 1 \\
\hline & tapertip cupgrass & 5 & & 1 & & & & \\
\hline & velvet mesquite & 7 & 1 & & & & & \\
\hline \multirow[t]{22}{*}{29} & Arizona foldwing & 1 & & & & & & \\
\hline & Bermudagrass & 4 & 2 & 2 & 1 & 2 & 4 & 59 \\
\hline & Fremont cottonwood & 12 & 2 & 1 & 1 & & 2 & 62 \\
\hline & Grisebach's bristlegrass & 1 & & & & 1 & & \\
\hline & jungle ricegrass & 1 & & & & 1 & & \\
\hline & Lehmann's lovegrass & 3 & 1 & 1 & & 1 & & \\
\hline & Mexican fireplant & 1 & & & & & & \\
\hline & New Mexico copperleaf & 4 & & & 1 & & & \\
\hline & carelessweed & 8 & 2 & 2 & 2 & 4 & 4 & 32 \\
\hline & cheeseweed burrobrush & 2 & & & & & & \\
\hline & cocklebur & 1 & & & & & & \\
\hline & feather fingergrass & 6 & 1 & 2 & 1 & 1 & 2 & 3 \\
\hline & few-flower beggarticks & 8 & 2 & & 1 & 1 & 1 & 3 \\
\hline & fringed twinevine & 3 & 2 & & 1 & & & \\
\hline & gooding willow & 6 & & & & & 2 & 53 \\
\hline & longtube four o'clock & 2 & & & & & & \\
\hline & mule's fat & 4 & & & & & 1 & 9 \\
\hline & netleaf hackberry & 3 & & & 1 & & & \\
\hline & ragweed & 4 & & & & & 1 & 1 \\
\hline & tapertip cupgrass & 1 & & & 1 & & & \\
\hline & velvet mesquite & 2 & & & & & & \\
\hline & yellow sweet-clover & 1 & & & & & & \\
\hline \multirow[t]{6}{*}{$30 \mathrm{~A}$} & Lehmann's lovegrass & 7 & & 1 & 2 & & & \\
\hline & Mexican fireplant & 1 & & & 1 & & & \\
\hline & New Mexico copperleaf & 1 & & & & & & \\
\hline & Orcutt's threeawn & 2 & & & & & & \\
\hline & Rothrock's grama & 5 & 2 & 1 & 2 & & & \\
\hline & camphorweed & 1 & & & & & & \\
\hline
\end{tabular}




\begin{tabular}{|c|c|c|c|c|c|c|c|c|}
\hline \multirow[b]{2}{*}{ Plot name } & \multirow[b]{2}{*}{ Common name } & \multicolumn{5}{|c|}{ Frequency of occurrence in modular quadrata } & \multicolumn{2}{|c|}{$\begin{array}{c}\text { Total number of point intercepts } \\
\text { along transects }\end{array}$} \\
\hline & & $10 \times 10$ & NE & NW & SE & SW & $\begin{array}{l}\text { modules and } \\
\text { plots }^{c}\end{array}$ & Intercept sumb \\
\hline \multirow[t]{21}{*}{$30 \mathrm{~A}$} & carelessweed & 8 & & 1 & 1 & 1 & 4 & 12 \\
\hline & cutleaf goldenweed & 2 & & & & & & \\
\hline & delicate muhly & 3 & & & & 1 & 1 & 3 \\
\hline & doubleclaw & 1 & & & & & & \\
\hline & feather fingergrass & 4 & & & 1 & 1 & 2 & 8 \\
\hline & few-flower beggarticks & 3 & & & & 1 & 1 & 1 \\
\hline & field sandbur & 1 & & & & & & \\
\hline & flatcrown buckwheat & 6 & & & & & 1 & 1 \\
\hline & gooding willow & 2 & & & 1 & & & \\
\hline & hairy crabgrass & 1 & & & & & & \\
\hline & low rattlebox & 4 & 1 & 1 & 1 & 1 & & \\
\hline & needle grama & 4 & 2 & 2 & 1 & 2 & 4 & 95 \\
\hline & plains lovegrass & 2 & 1 & 1 & & & & \\
\hline & prickly Russian thistle & 2 & & & & & & \\
\hline & purple grama & 1 & 1 & & & & & \\
\hline & ragweed & 1 & & & & & & \\
\hline & sand dropseed & 8 & & & 2 & & & \\
\hline & sixweeks threeawn & 5 & 2 & 1 & 1 & 1 & 4 & 18 \\
\hline & tapertip cupgrass & 3 & & & 1 & 1 & & \\
\hline & velvet mesquite & 4 & & & & & 3 & 26 \\
\hline & white blazingstar & 4 & & & & & & \\
\hline \multirow[t]{21}{*}{$31 \mathrm{~A}$} & Bermudagrass & 5 & 1 & 1 & 1 & 1 & 3 & 10 \\
\hline & Fremont cottonwood & 12 & 1 & 1 & & & 2 & 65 \\
\hline & Johnsongrass & 8 & & & & & 1 & 2 \\
\hline & Lehmann lovegrass & 2 & & & & & & \\
\hline & Mexican fireplant & 1 & 1 & & & & & \\
\hline & New Mexico copperleaf & 1 & & & & & & \\
\hline & carelessweed & 8 & 1 & 2 & & 2 & 6 & 19 \\
\hline & cocklebur & 2 & & & 1 & & & \\
\hline & desert broom & 4 & & & & & & \\
\hline & feather fingergrass & 2 & & & & & & \\
\hline & few-flower beggarticks & 7 & 1 & 2 & 1 & 1 & 3 & 14 \\
\hline & gooding willow & 11 & 2 & 3 & 2 & 3 & 4 & 100 \\
\hline & low rattlebox & 2 & & & 1 & & & \\
\hline & mule's fat & 5 & & & 1 & & 1 & 15 \\
\hline & netleaf hackberry & 2 & & & & & & \\
\hline & prairie sunflower & 4 & & & & & & \\
\hline & prickly Russian thistle & 4 & & & & & & \\
\hline & ragweed & 2 & & & & & & \\
\hline & sacred thorn-apple & 1 & & & & & & \\
\hline & tapertip cupgrass & 2 & & & & & 1 & 1 \\
\hline & velvet mesquite & 4 & & & & & & \\
\hline \multirow[t]{12}{*}{$32 \mathrm{~A}$} & Bermudagrass & 4 & & 2 & 1 & 2 & 3 & 71 \\
\hline & Rothrock's grama & 1 & & & & & & \\
\hline & Thurber pepperweed & 1 & & & & & & \\
\hline & buff petal & 1 & & & & & & \\
\hline & buffalo gourd & 3 & & & & 1 & 1 & 1 \\
\hline & carelessweed & 7 & 2 & 1 & 1 & 1 & 3 & 3 \\
\hline & catclaw & 5 & & & 3 & & 1 & 11 \\
\hline & desert broom & 4 & & & & & & \\
\hline & feather fingergrass & 2 & & & & & & \\
\hline & fringed twinevine & 8 & & & & 1 & 1 & 2 \\
\hline & graythorn & 7 & & 3 & & & 1 & 4 \\
\hline & horehound & 2 & & & & & 1 & 3 \\
\hline
\end{tabular}




\begin{tabular}{|c|c|c|c|c|c|c|c|c|}
\hline \multirow[b]{2}{*}{ Plot name } & \multirow[b]{2}{*}{ Common name } & \multicolumn{5}{|c|}{ Frequency of occurrence in modular quadrata } & \multicolumn{2}{|c|}{$\begin{array}{c}\text { Total number of point intercepts } \\
\text { along transects }\end{array}$} \\
\hline & & $10 \times 10$ & NE & NW & SE & SW & plots $^{c}$ & Intercept sumb \\
\hline \multirow[t]{8}{*}{$32 \mathrm{~A}$} & needle grama & 2 & 1 & & & & 1 & 1 \\
\hline & netleaf hackberry & 2 & & & 2 & & & \\
\hline & sand dropseed & 6 & & & & & & \\
\hline & sixweeks threeawn & 1 & & & & & & \\
\hline & snailseed & 3 & & 2 & & & & \\
\hline & spidergrass & 1 & & & & & & \\
\hline & stinkgrass & 2 & & & & & 1 & 2 \\
\hline & velvet mesquite & 12 & & 2 & & & 4 & 60 \\
\hline \multirow[t]{14}{*}{35} & Bermudagrass & 2 & & 1 & & 1 & 2 & 29 \\
\hline & Fremont cottonwood & 3 & & & & & & \\
\hline & Grisebach's bristlegrass & 1 & & & & 1 & & \\
\hline & Lehmann's lovegrass & 3 & & & & & & \\
\hline & Thurber pepperweed & 1 & & & & & & \\
\hline & carelessweed & 8 & 6 & 2 & 2 & 6 & 4 & 75 \\
\hline & cheeseweed burrobrush & 5 & 1 & & & & 1 & 1 \\
\hline & feather fingergrass & 6 & 2 & & & 3 & & \\
\hline & few-flower beggarticks & 4 & & & & & & \\
\hline & needle grama & 3 & 1 & & & 1 & 2 & 26 \\
\hline & prickly Russian thistle & 8 & & & & 2 & & \\
\hline & ragweed & 1 & & & & & & \\
\hline & sand dropseed & 4 & & & & & 1 & 1 \\
\hline & sorrel buckwheat & 2 & & & & & & \\
\hline \multirow[t]{15}{*}{37} & Bermudagrass & 3 & & 1 & & & & \\
\hline & Fremont cottonwood & 3 & & 2 & & & 1 & 28 \\
\hline & Grisebach's bristlegrass & 1 & & & & & & \\
\hline & Lehmann's lovegrass & 8 & & 1 & & & & \\
\hline & carelessweed & 8 & 2 & 4 & 4 & & & \\
\hline & feather fingergrass & 7 & 2 & 2 & 2 & 1 & 3 & 8 \\
\hline & few-flower beggarticks & 1 & & 1 & & & & \\
\hline & needle grama & 4 & 1 & 2 & 3 & 1 & 4 & 66 \\
\hline & prickly Russian thistle & 3 & & & & & & \\
\hline & ragweed & 2 & & & & & & \\
\hline & sand dropseed & 4 & & 1 & & & & \\
\hline & sixweeks grama & 1 & & & & & & \\
\hline & sorrel buckwheat & 2 & & & & & & \\
\hline & tapertip cupgrass & 1 & & 1 & & & & \\
\hline & white blazingstar & 2 & & & & & & \\
\hline \multirow[t]{11}{*}{40} & Bermudagrass & 2 & & & 1 & & & \\
\hline & Lehmann's lovegrass & 3 & & & 1 & & & \\
\hline & carelessweed & 8 & & 1 & 2 & 2 & 4 & 14 \\
\hline & desert honeysuckle & 3 & & & & & & \\
\hline & feather fingergrass & 4 & & 1 & 1 & 1 & 1 & 3 \\
\hline & mule's fat & 7 & & & & & 7 & 114 \\
\hline & needle grama & 4 & 1 & 3 & 3 & 1 & 4 & 23 \\
\hline & prairie sunflower & 2 & & & & & & \\
\hline & prickly Russian thistle & 1 & & & & & 2 & 14 \\
\hline & ragweed & 1 & & & & & & \\
\hline & white blazingstar & 1 & & & & & & \\
\hline \multirow[t]{6}{*}{ AG1 } & Bermudagrass & 4 & & 1 & & & 2 & 42 \\
\hline & Purple 3-awn & 3 & & 1 & & & 2 & 4 \\
\hline & camphorweed & 3 & & & & & & \\
\hline & carelessweed & 6 & & 1 & 1 & & 2 & 5 \\
\hline & cutleaf goldenweed & 1 & & & & & & \\
\hline & desert broom & 2 & & & & & & \\
\hline
\end{tabular}




\begin{tabular}{|c|c|c|c|c|c|c|c|c|}
\hline \multirow[b]{2}{*}{ Plot name } & \multirow[b]{2}{*}{ Common name } & \multicolumn{5}{|c|}{ Frequency of occurrence in modular quadrata } & \multicolumn{2}{|c|}{$\begin{array}{c}\text { Total number of point intercepts } \\
\text { along transects }\end{array}$} \\
\hline & & $10 \times 10$ & $\mathrm{NE}$ & NW & SE & SW & $\begin{array}{c}\text { Number of } \\
\text { modules and } \\
\text { plots }^{c}\end{array}$ & Intercept sumb \\
\hline \multirow[t]{12}{*}{ AG1 } & doubleclaw & 1 & & 1 & & & & \\
\hline & feather fingergrass & 2 & & & & & 1 & 1 \\
\hline & needle grama & 3 & & 2 & & & & \\
\hline & prickly Russian thistle & 4 & 1 & 3 & 1 & & 2 & 7 \\
\hline & procumbent sida & 2 & & & & & & \\
\hline & ragweed & 2 & & 1 & & & & \\
\hline & sand dropseed & 5 & & 1 & & & 2 & 2 \\
\hline & sixweeks grama & 1 & & & & & & \\
\hline & slender grama & 1 & & & & & & \\
\hline & spidergrass & 3 & & 2 & 1 & & & \\
\hline & stinkgrass & 2 & & 1 & & & & \\
\hline & velvet mesquite & 5 & & 1 & & & 1 & 1 \\
\hline \multirow[t]{13}{*}{ Bosque 1} & Bermudagrass & 1 & & 1 & & & & \\
\hline & Drummond's clematis & 4 & & 1 & & & 5 & 34 \\
\hline & New Mexico copperleaf & 2 & & 2 & 2 & & 1 & 1 \\
\hline & blue elderberry & 6 & & 1 & 2 & & 3 & 64 \\
\hline & few-flower beggarticks & 2 & & 1 & 1 & & & \\
\hline & fringed twinevine & 5 & & & 2 & & & \\
\hline & horehound & 1 & & & & & & \\
\hline & netleaf hackberry & 6 & & 1 & 1 & & 6 & 29 \\
\hline & procumbent sida & 1 & & & 1 & & & \\
\hline & ragweed & 1 & & & & & & \\
\hline & ruellia & 2 & & 1 & & & 1 & 7 \\
\hline & snailseed & 6 & & 2 & 1 & & 5 & 14 \\
\hline & velvet mesquite & 6 & & 1 & 3 & & 6 & 195 \\
\hline \multirow[t]{22}{*}{ Rip 1} & Arizona foldwing & 2 & & & & & 1 & 1 \\
\hline & Bermudagrass & 5 & 1 & 1 & & & 3 & 49 \\
\hline & Fremont cottonwood & 9 & 2 & 1 & & & 5 & 203 \\
\hline & Grisebach's bristlegrass & 2 & & & & & & \\
\hline & Mexican morningglory & 4 & & & & & & \\
\hline & New Mexico copperleaf & 2 & & & 1 & & 2 & 9 \\
\hline & blue elderberry & 4 & & & & & & \\
\hline & carelessweed & 6 & 2 & & & & 3 & 15 \\
\hline & cudweed sagewort & 1 & & & & & & \\
\hline & desert broom & 1 & & & & & & \\
\hline & few-flower beggarticks & 4 & 1 & 1 & 1 & & 3 & 13 \\
\hline & fringed twinevine & 7 & & & & 1 & & \\
\hline & giant reed & 2 & & & & & & \\
\hline & gooding willow & 11 & 3 & 1 & 2 & & 7 & 127 \\
\hline & hophornbeam copperleaf & 2 & & & & & & \\
\hline & longtube four o'clock & 3 & & & & & & \\
\hline & low rattlebox & 1 & & & & & & \\
\hline & mule's fat & 2 & & & 2 & & & \\
\hline & netleaf hackberry & 3 & & & 1 & & & \\
\hline & sacred thorn-apple & 2 & & & & & & \\
\hline & scarlet spiderling & 2 & & & & & 1 & 3 \\
\hline & weeping lovegrass & 1 & & & & & & \\
\hline
\end{tabular}

a Number of times a species was recorded in all quadrats and height categories. For all plots except Bosque 1 (which was half the size of the others) the maximum frequency was 12 for $10 \times 10$ m modules and 6 for each of the four $1 \times 1 \mathrm{~m}$ quadrats.

${ }^{b}$ Number of times a species was recorded along all line transects in each plot. For all plots except Bosque 1, the maximum frequency was 1200.

c Number of line transects in which species was recorded. For all plots except Bosque 1, the maximum number was 12. 
Appendix R. Plant species recorded in $10 \times 10$ m modular plots (P), point-intercept transects within modular plots (TR) or in both modular plots and point-intercept transects (B), Tumacácori NHP, 2002. Species in boldface-type are non-native. See Appendix A for common names.

\begin{tabular}{|c|c|c|c|c|c|c|c|c|c|c|c|c|c|c|c|c|c|c|c|c|c|c|c|}
\hline \multirow[b]{2}{*}{ Family } & \multirow[b]{2}{*}{ Genus } & \multirow[b]{2}{*}{ Species } & \multicolumn{20}{|c|}{ Plot name } & \multirow[b]{2}{*}{ Number of plots } \\
\hline & & & 1 & 13 & 16 & 18 & $21 \mathrm{~A}$ & $24 \mathrm{~A}$ & 29 & $30 \mathrm{~A}$ & $31 \mathrm{~A}$ & $32 \mathrm{~A}$ & 35 & 37 & 4 & 40 & 6 & $8 a$ & 9 & AG1 & $\begin{array}{c}\text { Bosque } \\
1\end{array}$ & $\begin{array}{c}\text { Rip } \\
1\end{array}$ & \\
\hline \multirow[t]{3}{*}{ Acanthaceae } & Anisacanthus & thurberi & & & & & & & & & & & & & & $\mathrm{P}$ & & & & & & & 1 \\
\hline & Dicliptera & resupinata & & & & & & & $P$ & & & & & & & & & & & & & B & 2 \\
\hline & Ruellia & nudiflora & & & & & & & & & & & & & & & & & & & $B$ & & 1 \\
\hline Amaranthaceae & Amaranthus & palmeri & $\mathrm{P}$ & $\mathrm{P}$ & & B & B & $B$ & B & $\mathrm{B}$ & B & $\mathrm{B}$ & B & $P$ & B & $\mathrm{B}$ & B & $P$ & B & $\mathrm{B}$ & & $\mathrm{B}$ & 18 \\
\hline Asclepiadaceae & Funastrum & cynanchoides & & B & & & & B & P & & & B & & & & & & B & & & $P$ & P & 7 \\
\hline \multirow[t]{16}{*}{ Asteraceae } & Ambrosia & confertiflora & & B & $P$ & & $P$ & B & B & $P$ & $P$ & & $P$ & $P$ & $P$ & $P$ & & $P$ & $P$ & $P$ & $\mathrm{P}$ & & 15 \\
\hline & Ambrosia & trifida & & & & & & & & & & & & & & & & & $\mathrm{P}$ & & & & 1 \\
\hline & Artemisia & Iudoviciana & & & & & & & & & & & & & & & & & & & & $P$ & 1 \\
\hline & Baccharis & salicifolia & & & & & & & B & & B & & & & & B & $\mathrm{P}$ & $B$ & & & & $P$ & 6 \\
\hline & Baccharis & sarothroides & $P$ & $\mathrm{~B}$ & $B$ & $P$ & & & & & $P$ & $\mathrm{P}$ & & & & & & $P$ & $\mathrm{P}$ & $P$ & & $P$ & 10 \\
\hline & Bidens & leptocephala & $P$ & & B & $P$ & $P$ & $B$ & B & $B$ & B & & $P$ & $P$ & & & $P$ & B & B & & $\mathrm{P}$ & $B$ & 15 \\
\hline & Gutierrezia & microcephala & & $P$ & & & & & & & & & & & & & & & & & & & 1 \\
\hline & Helianthus & annuus & & & & & $P$ & & & & & & & & & & & & $P$ & & & & 2 \\
\hline & Helianthus & petiolaris & & & & & & $\mathrm{P}$ & & & $\mathrm{P}$ & & & & & $\mathrm{P}$ & & & & & & & 3 \\
\hline & Heliomeris & Iongifolia & & & & & & & & & & & & & & & & & $P$ & & & & 1 \\
\hline & Heterotheca & subaxillaris & & & & & & & & $P$ & & & & & & & & & & $P$ & & & 2 \\
\hline & Hymenoclea & monogyra & & & & B & & & $P$ & & & & $B$ & & & & $B$ & & & & & & 4 \\
\hline & Isocoma & tenuisecta & & $P$ & & & & & & & & & & & & & & & & & & & 1 \\
\hline & Machaeranthera & pinnatifida & & P & & & & & & P & & & & & & & & & $\mathrm{P}$ & $P$ & & & 4 \\
\hline & Senecio & flaccidus & & & $P$ & & TR & & & & & & & & & & & & & & & & 2 \\
\hline & Xanthium & strumarium & & & & & & & $P$ & & $P$ & & & & & & & & $P$ & & & & 3 \\
\hline Bixaceae & Amoreuxia & palmatifida & & & $P$ & & & & & & & & & & & & & & & & & & 1 \\
\hline Brassicaceae & Lepidium & thurberi & & & & & & & & & & $P$ & $P$ & & & & & & & & & & 2 \\
\hline Cactaceae & Opuntia & spinosior & & & & & & & & & & & & & & & $\mathrm{P}$ & & & & & & 1 \\
\hline Caprifoliaceae & Sambucus & nigra & & & $\mathrm{P}$ & & & B & & & & & & & & & & & & & $\mathrm{B}$ & $P$ & 4 \\
\hline \multirow[t]{5}{*}{ Chenopodiaceae } & Salsola & kali & $\mathbf{P}$ & $P$ & & $P$ & & $P$ & & $\mathbf{P}$ & $P$ & & $\mathbf{P}$ & $\mathbf{P}$ & & B & B & $\mathbf{P}$ & $P$ & B & & & 13 \\
\hline & Ipomoea & barbatisepala & & & & & & & & & & & & & & & & & $\mathrm{P}$ & & & & 1 \\
\hline & Ipomoea & coccinea & & & & & & & & & & & & & & & & & & & & $\mathbf{P}$ & 2 \\
\hline & Ipomoea & costellata & & $\mathrm{P}$ & & & & & & & & & & & & & & & & & & & 1 \\
\hline & Ipomoea & hederacea & & & $\mathbf{P}$ & & & & & & & & & & & & $P$ & $\mathbf{P}$ & $\mathbf{P}$ & & & & 4 \\
\hline Cucurbitaceae & Cucurbita & foetidissima & & & & & & & & & & B & & & & & & & & & & & 1 \\
\hline \multirow[t]{4}{*}{ Euphorbiaceae } & Acalypha & neomexicana & & & $P$ & & & $B$ & $P$ & $\mathrm{P}$ & $P$ & & & & & & & $B$ & $P$ & & B & B & 9 \\
\hline & Acalypha & ostryifolia & & & & & & & & & & & & & & & & & & & & $\mathrm{P}$ & 1 \\
\hline & Chamaesyce & hyssopifolia & & & & & & & & & & & & & & & & & $P$ & & & & 1 \\
\hline & Euphorbia & heterophylla & & & $P$ & & & $B$ & $P$ & $P$ & P & & & & & & & & B & & & & 6 \\
\hline \multirow[t]{2}{*}{ Fabaceae } & Acacia & greggii & & & B & & & & & & & $B$ & & & B & & & & & & & & 3 \\
\hline & Crotalaria & pumila & & & & & & & & $\mathrm{P}$ & $\mathrm{P}$ & & & & & & & & $\mathrm{P}$ & & & $\mathrm{P}$ & 4 \\
\hline
\end{tabular}




\begin{tabular}{|c|c|c|c|c|c|c|c|c|c|c|c|c|c|c|c|c|c|c|c|c|c|c|c|}
\hline \multirow[b]{2}{*}{ Family } & \multirow[b]{2}{*}{ Genus } & \multirow[b]{2}{*}{ Species } & \multicolumn{20}{|c|}{ Plot name } & \multirow[b]{2}{*}{ Number of plots } \\
\hline & & & 1 & 13 & 16 & 18 & $21 \mathrm{~A}$ & $24 \mathrm{~A}$ & 29 & $30 \mathrm{~A}$ & $31 \mathrm{~A}$ & $32 \mathrm{~A}$ & 35 & 37 & 4 & 40 & 6 & $8 a$ & 9 & AG1 & $\begin{array}{c}\text { Bosque } \\
1 \\
\end{array}$ & $\begin{array}{c}\text { Rip } \\
1 \\
\end{array}$ & \\
\hline \multirow[t]{2}{*}{ Fabaceae } & Melilotus & officinalis & & & & & & & $P$ & & & & & & & & & & $\mathbf{P}$ & & & & 2 \\
\hline & Prosopis & velutina & B & B & $B$ & & & $P$ & $P$ & B & $P$ & B & & & B & & & & & $B$ & $B$ & & 11 \\
\hline Juglandaceae & Juglans & major & & & & & & & & & & & & & & & & $B$ & & & & & 1 \\
\hline Lamiaceae & Marrubium & vulgare & & & & & & & & & & B & & & & & & & & & $\mathbf{P}$ & & 2 \\
\hline \multirow[t]{2}{*}{ Loasaceae } & Mentzelia & albicaulis & & & & & B & & & $P$ & & & & $P$ & & $P$ & $P$ & & & & & & 5 \\
\hline & Mentzelia & aspera & & & $\mathrm{P}$ & & $P$ & & & & & & & & & & $B$ & & & & & & 3 \\
\hline \multirow[t]{3}{*}{ Malvaceae } & Anoda & cristata & & & & & & $\mathrm{P}$ & & & & & & & & & & & & & & & 1 \\
\hline & Rhynchosida & physocalyx & & B & $P$ & & & & & & & $\mathrm{P}$ & & & & & & & & & & & 3 \\
\hline & Sida & abutifolia & & B & & & & & & & & & & & & & & & & $\mathbf{P}$ & $\mathbf{P}$ & & 3 \\
\hline Menispermaceae & Cocculus & diversifolius & & & $B$ & & & $P$ & & & & $P$ & & & $B$ & & & & & & B & & 5 \\
\hline \multirow[t]{3}{*}{ Nyctaginaceae } & Boerhavia & coccinea & & & & & & & & & & & & & & & & & & & & $B$ & 1 \\
\hline & Boerhavia & scandens & & $P$ & B & & & & & & & & & & $\mathrm{P}$ & & & & & & & & 3 \\
\hline & Mirabilis & longiflora & & & & & & & $P$ & & & & & & & & & & & & & $P$ & 2 \\
\hline Oleaceae & Fraxinus & velutina & & & & & & & & & & & & & & & & $\mathrm{P}$ & & & & & 1 \\
\hline \multirow[t]{2}{*}{ Papaveraceae } & Argemone & pleiacantha & & $P$ & & & & & & & & & & & & & & & & & & & 1 \\
\hline & Argemone & polyanthemos & & & & & $P$ & & & & & & & & & & & & & & & & 1 \\
\hline Pedaliaceae & Proboscidea & parviflora & & & & & & & & $P$ & & & & & & & $P$ & & & $\mathrm{P}$ & & & 3 \\
\hline Phytolaccaceae & Rivina & humilis & & & $\mathrm{P}$ & & & & & & & & & & $B$ & & & & & & & & 2 \\
\hline Poaceae & Aristida & adscensionis & & & & & & & & $B$ & & $P$ & & & & & $P$ & & & & & & 3 \\
\hline \multirow[t]{20}{*}{ Poaceae } & Aristida & purpurea & & & & & & & & & & & & & & & & & & $B$ & & & 1 \\
\hline & Aristida & schiedeana & & & & & & & & $P$ & & & & & & & & & & & & & 1 \\
\hline & Aristida & ternipes & & $B$ & & & $P$ & & & & & $P$ & & & & & & & & $P$ & & & 4 \\
\hline & Arundo & donax & & & & & & & & & & & & & & & & & & & & $P$ & 1 \\
\hline & Bouteloua & aristidoides & $B$ & $B$ & & B & B & $\mathrm{P}$ & & $B$ & & $B$ & $B$ & $B$ & $P$ & $B$ & $B$ & & $B$ & $P$ & & & 14 \\
\hline & Bouteloua & barbata & & $P$ & & & & & & & & & & $P$ & & & & & & $P$ & & & 3 \\
\hline & Bouteloua & gracilis & & & & & $\mathrm{P}$ & & & & & & & & & & & & & & & & 1 \\
\hline & Bouteloua & radicosa & & & & & & & & $P$ & & & & & & & & & & & & & 1 \\
\hline & Bouteloua & repens & & $P$ & & & & & & & & & & & & & & & & $P$ & & & 2 \\
\hline & Bouteloua & rothrockii & & $P$ & & & & & & $P$ & & $P$ & & & & & & & & & & & 3 \\
\hline & Cenchrus & longispinus & & & & & $P$ & & & $P$ & & & & & & & & & & & & & 2 \\
\hline & Cenchrus & spinifex & & & & & & B & & & & & & & & & & & & & & & 1 \\
\hline & Chloris & virgata & $P$ & $\mathrm{P}$ & & $B$ & $B$ & $\mathrm{~B}$ & $B$ & $B$ & $P$ & $P$ & $P$ & $B$ & & $B$ & $B$ & & B & $B$ & & & 15 \\
\hline & Cynodon & dactylon & & $P$ & $\mathbf{P}$ & $\mathbf{P}$ & B & B & B & & B & B & B & $\mathbf{P}$ & & $P$ & $P$ & B & B & B & $\mathbf{P}$ & B & 17 \\
\hline & Digitaria & sanguinalis & & & & & & & & $P$ & & & & & & & & $\mathrm{P}$ & $P$ & & & & 3 \\
\hline & Echinochloa & colona & & & & & & & $P$ & & & & & & & & & $\mathbf{P}$ & & & & & 2 \\
\hline & Eragrostis & cilianensis & $\mathbf{P}$ & $\mathbf{P}$ & & & $\mathbf{P}$ & TR & & & & B & & & & & & & $\mathbf{P}$ & $\mathbf{P}$ & & & 7 \\
\hline & Eragrostis & curvula & & & & & & & & & & & & & & & & & & & & $\mathbf{P}$ & 1 \\
\hline & Eragrostis & intermedia & & & & & & & & $P$ & & & & & & & & & $B$ & & & & 2 \\
\hline & Eragrostis & lehmanniana & & & & $\mathbf{P}$ & $\mathbf{P}$ & & $P$ & $\mathbf{P}$ & $\mathbf{P}$ & & $\mathbf{P}$ & $\mathbf{P}$ & & $\mathbf{P}$ & & & B & & & & 9 \\
\hline
\end{tabular}




\begin{tabular}{|c|c|c|c|c|c|c|c|c|c|c|c|c|c|c|c|c|c|c|c|c|c|c|c|}
\hline \multirow[b]{2}{*}{ Family } & \multirow[b]{2}{*}{ Genus } & \multirow[b]{2}{*}{ Species } & \multicolumn{20}{|c|}{ Plot name } & \multirow[b]{2}{*}{ Number of plots } \\
\hline & & & 1 & 13 & 16 & 18 & $21 \mathrm{~A}$ & $24 \mathrm{~A}$ & 29 & $30 \mathrm{~A}$ & $31 \mathrm{~A}$ & $32 \mathrm{~A}$ & 35 & 37 & 4 & 40 & 6 & $8 a$ & 9 & AG1 & $\begin{array}{c}\text { Bosque } \\
1\end{array}$ & $\begin{array}{c}\text { Rip } \\
1\end{array}$ & \\
\hline \multirow[t]{6}{*}{ Poaceae } & Eriochloa & acuminata & & & $P$ & $P$ & $B$ & $\mathrm{P}$ & $P$ & $P$ & $B$ & & & $P$ & & & $P$ & $P$ & $B$ & & & & 11 \\
\hline & Muhlenbergia & fragilis & & & & & & & & B & & & & & & & & & & & & & 1 \\
\hline & Setaria & grisebachii & & & & & & $P$ & $P$ & & & & $\mathrm{P}$ & $P$ & & & & & & & & $P$ & 5 \\
\hline & Sorghum & halepense & & & & & & & & & B & & & & & & & $\mathbf{P}$ & $\mathbf{P}$ & & & & 3 \\
\hline & Sporobolus & cryptandrus & & $\mathrm{P}$ & & & TR & $P$ & & $P$ & & $P$ & B & P & & & $P$ & & B & B & & & 10 \\
\hline & Urochloa & arizonica & & $P$ & & & & & & & & & & & & & & & & & & & 1 \\
\hline Polemoniaceae & Eriastrum & diffusum & & & & & & & & & & & & & & & $P$ & & & & & & 1 \\
\hline \multirow[t]{2}{*}{ Polygonaceae } & Eriogonum & deflexum & & & & & & & & B & & & & & & & $P$ & & & & & & 2 \\
\hline & Eriogonum & polycladon & & & & B & & & & & & & $P$ & $P$ & & & & & & & & & 3 \\
\hline Ranunculaceae & Clematis & drummondii & & & & & & & & & & & & & & & & & & & $B$ & & 1 \\
\hline \multirow[t]{2}{*}{ Rhamnaceae } & Ceanothus & greggii & & B & & & & & & & & & & & & & & & & & & & 1 \\
\hline & Ziziphus & obtusifolia & & & $P$ & & & B & & & & B & & & B & & & & & & & & 4 \\
\hline \multirow[t]{3}{*}{ Salicaceae } & Populus & fremontii & & & B & & & B & B & & B & & $\mathrm{P}$ & B & & & & $B$ & B & & & B & 9 \\
\hline & Salix & gooddingii & & & & & & & $B$ & $P$ & B & & & & & & $P$ & $\mathrm{~B}$ & B & & & $B$ & 7 \\
\hline & Salix & taxifolia & & & & & & & & & & & & & & & & & B & & & & 1 \\
\hline Solanaceae & Datura & wrightii & & & & & & & & & $P$ & & & & & & & $\mathrm{P}$ & & & & $P$ & 3 \\
\hline Ulmaceae & Celtis & laevigata & & & $B$ & & & $\mathrm{~B}$ & $\mathrm{P}$ & & P & $\mathrm{P}$ & & & $\mathrm{P}$ & & & $P$ & & & $B$ & $\mathrm{P}$ & 9 \\
\hline \multicolumn{3}{|c|}{ Number of species } & 8 & 25 & 21 & 11 & 18 & 23 & 22 & 27 & 21 & 20 & 14 & 15 & 10 & 11 & 19 & 20 & 30 & 18 & 13 & 22 & \\
\hline
\end{tabular}


Appendix S. Detailed results of fish surveys at Tumacácori NHP, 2001-2002. These data are summarized in Table 5.1. See Appendix B for scientific names.

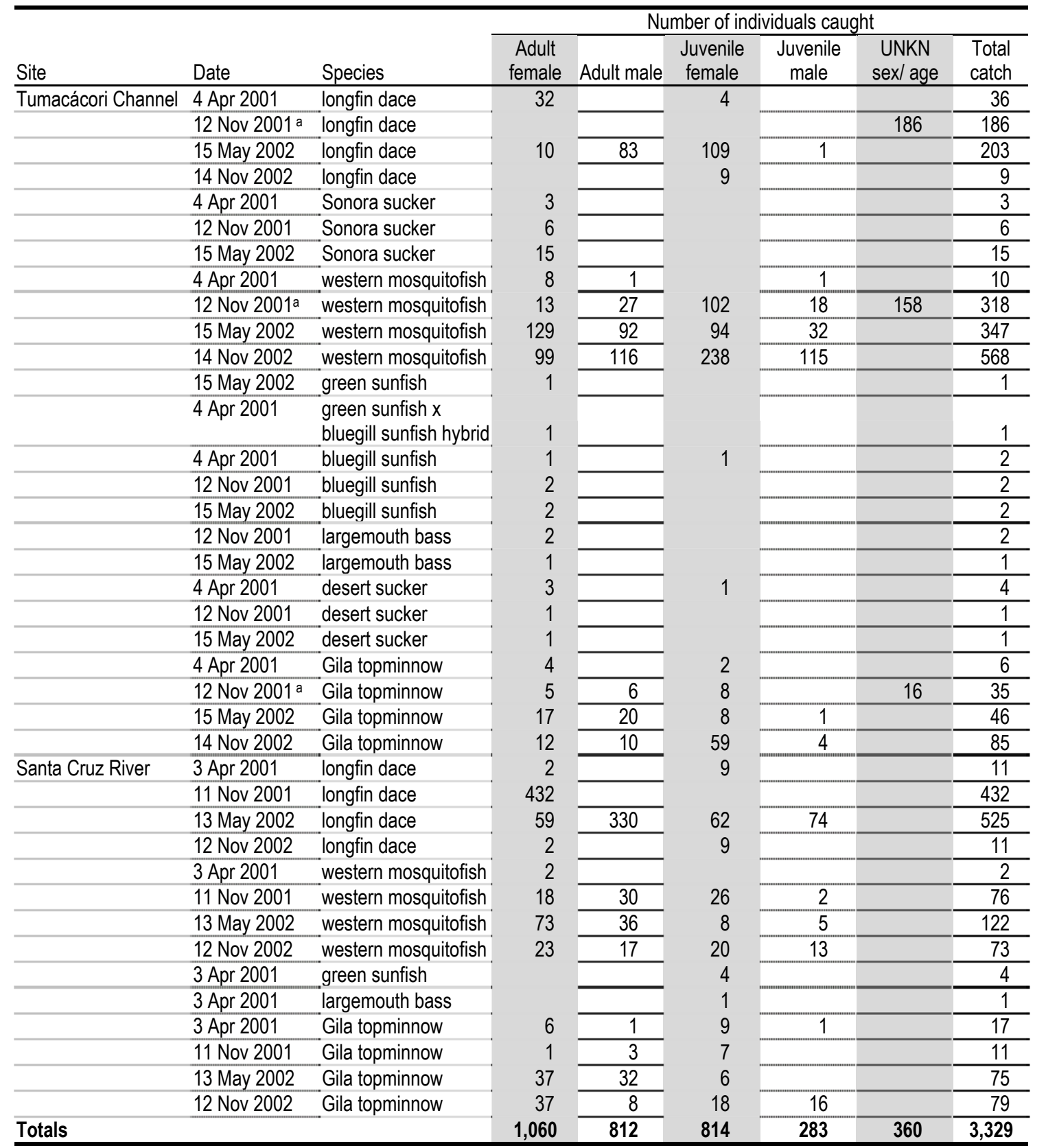

a Andrew Schultz (survey crew leader) noted that there were too many fish to count and estimated that Gila topminnow and western mosquitofish numbered in the "hundreds to thousands" and longfin dace numbered in the "hundreds". 
Appendix T. Total number of birds detected during incidental observations and VCP surveys for the time period of the most intensive surveys, Tumacácori NHP, 2001-2002. Numbers should not used as a measure of relative abundance because there was not consistent sampling effort across time or between survey types. See Table 6.2 for relative abundance of the most common species and Appendix D for scientific names.

\begin{tabular}{|c|c|c|c|c|c|c|c|c|}
\hline \multirow[b]{3}{*}{ Common name } & \multicolumn{8}{|c|}{ Month } \\
\hline & \multicolumn{2}{|c|}{ April } & \multicolumn{2}{|c|}{ May } & \multicolumn{2}{|c|}{ June } & \multicolumn{2}{|c|}{ July } \\
\hline & $1-15$ & $16-30$ & $1-15$ & $16-31$ & $1-15$ & $16-30$ & $1-15$ & $16-31$ \\
\hline great blue heron & & 1 & & 2 & 1 & 1 & & \\
\hline white-faced lbis & & 1 & & 1 & & & & \\
\hline turkey vulture & 1 & 9 & & 1 & 1 & & & 3 \\
\hline black vulture & 1 & 2 & & & & & & 3 \\
\hline black-bellied whistling duck & & & & & 1 & & & 3 \\
\hline mallard & & 1 & & & & & & \\
\hline sharp-shinned hawk & & 1 & & & & & & \\
\hline Cooper's hawk & 2 & 4 & & 1 & 1 & & 1 & 3 \\
\hline gray hawk & 6 & 9 & & 7 & 4 & 3 & 3 & 4 \\
\hline Swainson's hawk & & & & & & & & 1 \\
\hline red-tailed hawk & & & & & & & & 1 \\
\hline American kestrel & & & & & & & & 1 \\
\hline peregrine falcon & & & & 2 & & & & \\
\hline Gambel's quail & 1 & 11 & 3 & 5 & 4 & & 2 & 10 \\
\hline killdeer & 1 & 1 & & 1 & & & & \\
\hline spotted sandpiper & & 1 & & & & & & \\
\hline band-tailed pigeon & & & & & 1 & & & \\
\hline white-winged dove & 14 & 26 & 5 & 21 & 19 & 10 & 3 & 12 \\
\hline mourning dove & 12 & 39 & 6 & 15 & 7 & 5 & 2 & 18 \\
\hline Inca dove & & & & 2 & & 1 & & 1 \\
\hline common ground-dove & 7 & 3 & & 3 & 4 & & 1 & 6 \\
\hline yellow-billed cuckoo & & & & & 5 & 4 & 1 & 10 \\
\hline greater roadrunner & 2 & 4 & & 6 & & & & \\
\hline barn owl & & 1 & & & & & & \\
\hline lesser nighthawk & & & & & 1 & 1 & & \\
\hline broad-billed hummingbird & 6 & 16 & 2 & 7 & 3 & 2 & 1 & 13 \\
\hline black-chinned hummingbird & 1 & 4 & 2 & 10 & 3 & 2 & & 1 \\
\hline Costa's hummingbird & & & & 2 & & & & \\
\hline broad-tailed hummingbird & 3 & & & & & & & \\
\hline green kingfisher & & & & & & & & 1 \\
\hline Lewis's woodpecker & & 2 & & & & & & \\
\hline Gila woodpecker & 21 & 45 & 4 & 26 & 25 & 10 & 7 & 24 \\
\hline ladder-backed woodpecker & 6 & 6 & 2 & 8 & 5 & 4 & 1 & 5 \\
\hline northern flicker & 1 & & & 4 & & 4 & & \\
\hline gilded flicker & & 1 & & & & & & \\
\hline rose-throated becard & & & & & & & & 1 \\
\hline northern beardless-tyrannulet & 3 & 10 & & 2 & 1 & 2 & & 1 \\
\hline western wood-pewee & & 2 & 1 & 1 & 2 & & & \\
\hline willow flycatcher & & & & 2 & 1 & 1 & & \\
\hline gray flycatcher & 1 & 2 & & & & & & \\
\hline pacific-slope flycatcher & & 1 & & & & & & \\
\hline cordilleran flycatcher & & & 1 & & & & & \\
\hline black phoebe & & & & & 1 & & & 1 \\
\hline Say's phoebe & 2 & 7 & & 3 & 2 & 1 & & 1 \\
\hline vermilion flycatcher & 5 & 19 & & 10 & 6 & 6 & 1 & 6 \\
\hline
\end{tabular}




\begin{tabular}{|c|c|c|c|c|c|c|c|c|}
\hline \multirow[b]{3}{*}{ Common name } & \multicolumn{8}{|c|}{ Month } \\
\hline & \multicolumn{2}{|c|}{ April } & \multicolumn{2}{|c|}{ May } & \multicolumn{2}{|c|}{ June } & \multicolumn{2}{|c|}{ July } \\
\hline & $1-15$ & $16-30$ & $1-15$ & $16-31$ & $1-15$ & $16-30$ & $1-15$ & $16-31$ \\
\hline dusky-capped flycatcher & 4 & 4 & & 6 & 4 & 5 & & 4 \\
\hline ash-throated flycatcher & 3 & 8 & 3 & 7 & 4 & & & 11 \\
\hline brown-crested flycatcher & & 7 & 2 & 14 & 15 & 7 & 2 & 6 \\
\hline sulphur-bellied flycatcher & & & & & & & 1 & \\
\hline Cassin's kingbird & 3 & 9 & 2 & 7 & 5 & 1 & 3 & 7 \\
\hline western kingbird & 2 & 7 & & 1 & 2 & & & 6 \\
\hline Bell's vireo & 9 & 20 & 5 & 14 & 10 & 6 & 3 & 17 \\
\hline warbling vireo & & 1 & 2 & 2 & & & & 1 \\
\hline plumbeous vireo & 1 & 2 & & & & & & \\
\hline Cassin's vireo & & & 1 & & & & & \\
\hline western scrub-jay & & 2 & & & & & & \\
\hline unknown raven & 2 & 4 & 3 & 3 & & & & 2 \\
\hline violet-green swallow & & 1 & & & & & & \\
\hline northern rough-winged swallow & 2 & 4 & & 2 & 1 & 1 & 1 & \\
\hline bank swallow & & & & 1 & & & & \\
\hline cliff swallow & & & & 2 & & & & 7 \\
\hline barn swallow & & 3 & & 2 & 2 & 1 & 1 & 3 \\
\hline bridled titmouse & 2 & 8 & & 7 & 3 & 3 & 1 & 3 \\
\hline verdin & 3 & 14 & 2 & 7 & 6 & 5 & 3 & 13 \\
\hline white-breasted nuthatch & & & & & & & 1 & 1 \\
\hline cactus wren & & & & & 1 & & & \\
\hline Bewick's wren & 20 & 32 & 6 & 32 & 18 & 6 & 5 & 12 \\
\hline house wren & 2 & 2 & & & & & & \\
\hline blue-gray gnatcatcher & 1 & 2 & & 1 & & & & \\
\hline black-tailed gnatcatcher & & 2 & & & & & & \\
\hline Swainson's thrush & & & 1 & & & & & \\
\hline northern mockingbird & 1 & 1 & & 3 & & 3 & & 2 \\
\hline curve-billed thrasher & 2 & 4 & & 6 & 1 & 4 & 2 & 7 \\
\hline crissal thrasher & & 1 & & & & & & \\
\hline European starling & & 5 & & & 2 & & & 1 \\
\hline phainopepla & 4 & 6 & 3 & 25 & 22 & 16 & 8 & 25 \\
\hline northern parula & & & & 1 & & & & \\
\hline orange-crowned warbler & 2 & & & & & & & \\
\hline Nashville warbler & 1 & & & & & & & \\
\hline Lucy's warbler & 16 & 35 & 8 & 31 & 19 & 2 & 6 & 9 \\
\hline yellow warbler & 3 & 9 & & 11 & 9 & 2 & 3 & 8 \\
\hline yellow-rumped warbler & 2 & & & & & & & \\
\hline black-throated gray warbler & 3 & 1 & & & & & & \\
\hline MacGillivray's warbler & 1 & & & 1 & & & & \\
\hline common yellowthroat & 2 & 6 & & 4 & 9 & 4 & 1 & 4 \\
\hline Wilson's warbler & 1 & 11 & & 2 & & & & \\
\hline yellow-breasted chat & & 5 & 2 & 42 & 30 & 23 & 12 & 35 \\
\hline summer tanager & 1 & 25 & 1 & 17 & 11 & 8 & 2 & 10 \\
\hline western tanager & & 2 & 1 & 2 & 1 & & & 7 \\
\hline green-tailed towhee & 5 & 1 & & 1 & 1 & & & \\
\hline canyon towhee & 1 & & 1 & 2 & & & & \\
\hline Abert's towhee & 1 & 9 & & 6 & 2 & 2 & 1 & 2 \\
\hline rufous-winged sparrow & 8 & 5 & & 3 & 1 & 1 & 2 & 3 \\
\hline rufous-crowned sparrow & 1 & & 1 & 2 & & & & 1 \\
\hline
\end{tabular}




\begin{tabular}{|c|c|c|c|c|c|c|c|c|}
\hline \multirow[b]{3}{*}{ Common name } & \multicolumn{8}{|c|}{ Month } \\
\hline & \multicolumn{2}{|c|}{ April } & \multicolumn{2}{|c|}{ May } & \multicolumn{2}{|c|}{ June } & \multicolumn{2}{|c|}{ July } \\
\hline & $1-15$ & $16-30$ & $1-15$ & $16-31$ & $1-15$ & $16-30$ & $1-15$ & $16-31$ \\
\hline chipping sparrow & 2 & 2 & & & & & & \\
\hline Brewer's sparrow & 3 & 2 & & & & & & \\
\hline lark sparrow & 4 & 3 & & & & & 1 & \\
\hline black-throated sparrow & 1 & & 1 & 4 & & & & 2 \\
\hline song sparrow & 4 & 18 & & 13 & 13 & 4 & 1 & 12 \\
\hline Lincoln's sparrow & 2 & & & & & & & \\
\hline white-crowned sparrow & 4 & 1 & & 2 & & & & \\
\hline northern cardinal & 9 & 27 & 1 & 9 & 12 & 9 & 3 & 14 \\
\hline pyrrhuloxia & 2 & & & 2 & & & & \\
\hline black-headed grosbeak & 1 & & 1 & & 3 & & & 3 \\
\hline blue grosbeak & & & & 5 & 2 & 5 & 3 & 4 \\
\hline lazuli bunting & & 1 & 1 & & & & & 3 \\
\hline indigo bunting & & & & & & & 1 & 1 \\
\hline varied bunting & & & & 2 & & 1 & 1 & 3 \\
\hline red-winged blackbird & & & 1 & 1 & & & & \\
\hline Brewer's blackbird & 1 & & & & & & & \\
\hline great-tailed grackle & & 11 & & 8 & 3 & 1 & 1 & 2 \\
\hline bronzed cowbird & & & & & & & & 3 \\
\hline brown-headed cowbird & & 11 & 4 & 28 & 24 & 11 & 4 & 14 \\
\hline hooded oriole & 1 & 6 & & 2 & 1 & & & 1 \\
\hline Bullock's oriole & 2 & & & 5 & 4 & 1 & 2 & 1 \\
\hline house finch & 9 & 21 & 3 & 6 & 9 & 3 & 1 & 8 \\
\hline lesser goldfinch & 11 & 14 & 1 & 10 & 1 & 3 & 4 & 16 \\
\hline house sparrow & 3 & 8 & & 3 & 5 & 3 & & 8 \\
\hline
\end{tabular}




\section{Appendix U. Summary of vegetation characteristics measured at VCP survey stations, Tumacácori NHP,}

2002.

\begin{tabular}{|c|c|c|c|c|c|c|c|}
\hline \multirow[b]{2}{*}{ Park unit } & \multirow[b]{2}{*}{ Station } & \multicolumn{3}{|c|}{$\begin{array}{l}\text { Mean vegetation } \\
\text { volume }(\%)\end{array}$} & \multicolumn{3}{|c|}{ Coverage (\%) } \\
\hline & & $0-0.5 \mathrm{~m}$ & $0.5-2.0 \mathrm{~m}$ & $>2.0 \mathrm{~m}$ & Litter & $\begin{array}{l}\text { Bare } \\
\text { ground }\end{array}$ & Rocks \\
\hline \multirow[t]{3}{*}{ Calabazas } & 1 & 44 & 25 & 1 & 46 & 51 & 9 \\
\hline & 2 & 35 & 29 & 28 & 61 & 30 & 10 \\
\hline & 3 & 45 & 47 & 63 & 90 & 3 & 0 \\
\hline \multirow[t]{2}{*}{ Guevavi } & 1 & 24 & 20 & 16 & 39 & 49 & 10 \\
\hline & 2 & 44 & 32 & 34 & 81 & 12 & 7 \\
\hline \multirow[t]{8}{*}{ Tumacácori } & 1 & 36 & 9 & 27 & 42 & 56 & 0 \\
\hline & 2 & 38 & 8 & 15 & 52 & 47 & 0 \\
\hline & 3 & 46 & 37 & 46 & 65 & 33 & 2 \\
\hline & 4 & 39 & 38 & 55 & 76 & 23 & 0 \\
\hline & 5 & 46 & 32 & 48 & 74 & 23 & 2 \\
\hline & 6 & 40 & 38 & 56 & 72 & 28 & 0 \\
\hline & 7 & 41 & 11 & 15 & 64 & 36 & 1 \\
\hline & 8 & 57 & 23 & 48 & 89 & 10 & 0 \\
\hline
\end{tabular}

\begin{tabular}{|c|c|c|c|c|c|c|c|c|c|c|c|c|c|c|}
\hline \multirow[b]{3}{*}{ Park unit } & \multirow[b]{3}{*}{ Station } & \multicolumn{13}{|c|}{ Frequency (Freq.) and mean height $(\mathrm{Ht} ; \mathrm{m})$ of dominant tree species at vegetation plots ${ }^{\mathrm{a}}$} \\
\hline & & \multirow{2}{*}{$\begin{array}{c}\begin{array}{c}\text { No } \\
\text { plant }\end{array} \\
\text { Freq. }\end{array}$} & \multicolumn{2}{|c|}{$\begin{array}{c}\text { Acacia } \\
\text { greggi }\end{array}$} & \multicolumn{2}{|c|}{$\begin{array}{c}\text { Celtis } \\
\text { reticulata }\end{array}$} & \multicolumn{2}{|c|}{$\begin{array}{l}\text { Populus } \\
\text { fremontii }\end{array}$} & \multicolumn{2}{|c|}{$\begin{array}{c}\text { Prosopis } \\
\text { velutina }\end{array}$} & \multicolumn{2}{|c|}{$\begin{array}{c}\text { Salix } \\
\text { gooddingii }\end{array}$} & \multicolumn{2}{|c|}{$\begin{array}{l}\text { Sambucus } \\
\text { mexicana }\end{array}$} \\
\hline & & & Freq. & $\mathrm{Ht}$ & Freq. & $\mathrm{Ht}$ & Freq. & $\mathrm{Ht}$ & Freq. & $\mathrm{Ht}$ & Freq. & $\mathrm{Ht}$ & Freq. & $\mathrm{Ht}$ \\
\hline \multirow[t]{3}{*}{ Calabazas } & 1 & 20 & & & & & & & & & & & & \\
\hline & 2 & 9 & & & 6 & 9 & & & 4 & 9 & & & 1 & 6 \\
\hline & 3 & & & & 6 & 9 & & & 13 & 8 & & & 1 & 6 \\
\hline \multirow[t]{2}{*}{ Guevavi } & 1 & 4 & & & 2 & 11 & 5 & 14 & 8 & 8 & & & 1 & 6 \\
\hline & 2 & 5 & & & 7 & 8 & & & 7 & 7 & & & 1 & 3 \\
\hline \multirow[t]{8}{*}{ Tumacácori } & 1 & & & & & & & & 18 & 8 & & & 1 & 5 \\
\hline & 2 & 3 & 1 & 6 & 1 & 8 & 4 & 11 & 11 & 8 & & & & \\
\hline & 3 & 5 & & & 1 & 7 & 4 & 11 & 5 & 8 & & & 5 & 7 \\
\hline & 4 & 1 & & & & & 16 & 12 & & & 3 & 11 & & \\
\hline & 5 & & & & & & 18 & 10 & & & 2 & 10 & & \\
\hline & 6 & & & & & & 13 & 13 & & & 7 & 13 & & \\
\hline & 7 & & & & & & 20 & 10 & & & & & & \\
\hline & 8 & 5 & & & & & 5 & 12 & 7 & 7 & 2 & 9 & 1 & 4 \\
\hline
\end{tabular}

a Recorded in the "possible cavity-bearing" category. 